\title{
Representações culturais da América indígena
}

\author{
Ana Raquel Portugal \\ Liliana Regalado de Hurtado \\ (orgs.)
}

PORTUGAL, AR., and HURTADO, LR., orgs. Representações culturais da América indígena [online]. São Paulo: Editora UNESP; São Paulo: Cultura Acadêmica, 2015. Desafios contemporâneos

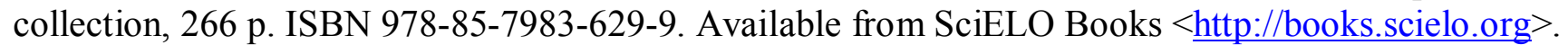

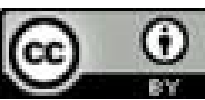

All the contents of this work, except where otherwise noted, is licensed under a Creative Commons Attribution 4.0 International license.

Todo o conteúdo deste trabalho, exceto quando houver ressalva, é publicado sob a licença Creative Commons Atribição $\underline{4.0}$.

Todo el contenido de esta obra, excepto donde se indique lo contrario, está bajo licencia de la licencia Creative Commons Reconocimento 4.0. 
ANA RAQUEL PORTUGAL

LILIANA REGALADO DE HURTADO

(ORGS.)

CULTURA

ACADÊMICAs

\section{REPRESENTAÇÕES CULTURAIS DA AMÉRICA INDÍGENA}

DES A F O O C O NTEMPOR A NE OS

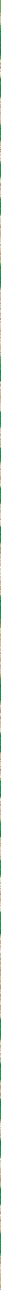




\section{REPRESENTAÇÕES CULTURAIS DA AMÉRICA INDÍGENA}




\section{Conselho científico}

Prof. Dr. Alexandre Suárez de Oliveira (FAAC-Unesp)

Prof. Dr. Edemir de Carvalho (FFC-Unesp)

Profa. Dra. Elaine Patrícia G. Serrano (FAAC-Unesp)

Profa. Dra. Denise Dantas (FAU-USP)

Prof. Dr. Fábio Fernandes Vilela (Ibilce-Unesp)

Profa. Dra. Fátima Aparecida dos Santos (UnB-DF)

Prof. Dr. Fernando Atique (Unifesp)

Profa. Dra. Kátia Maria Roberto de Oliveira Kodama (FCT-Unesp)

Prof. Dr. Marcos da Costa Braga (FAU-USP)

Profa. Dra. Marília Coelho (FCT-Unesp)

Profa. Dra. Paula F. Vermeersch (FCT-Unesp)

Prof. Dr. Paulo César Castral (IAU-USP)

Profa. Dra. Rosa Maria Araújo Simões (FAAC-Unesp)

Prof. Dr. Sidney Tamai (FAAC-Unesp)

Profa. Dra. Silvana Aparecida Alves (FAAC-Unesp)

Prof. Dr. Vladimir Benincasa (FAAC-Unesp)

Prof. Dr. Wilson Ribeiro dos Santos Junior (PUC-Campinas-SP) 


\section{ANA RAQUEL PORTUGAL \\ LILIANA REGALADO DE HURTADO \\ (Organizadores)}

\section{REPRESENTAÇÕES CULTURAIS DA AmÉriCA INDÍGENA}

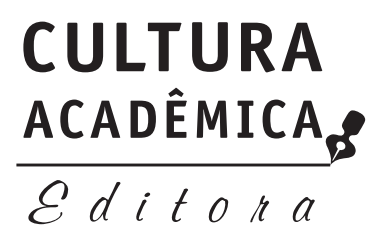


(C) 2015 Cultura Acadêmica

Cultura Acadêmica

Praça da Sé, 108

01001-900 - São Paulo - SP

Tel.: (0xx11) 3242-7171

Fax: (0xx11) 3242-7172

www.culturaacademica.com.br

feu@editora.unesp.br

CIP - Brasil. Catalogação na publicação

Sindicato Nacional dos Editores de Livros, RJ

R336

Representações culturais da América indígena [recurso eletrônico] / organização Ana Raquel Portugal, Liliana Regalado de Hurtado. - 1. ed.

- São Paulo: Cultura Acadêmica, 2015.

recurso digital

Formato: ePDF

Requisitos do sistema: Adobe Acrobat Reader

Modo de acesso: World Wide Web

ISBN 978-85-7983-629-9 (recurso eletrônico)

1. Índios do Brasil - Estudo e ensino. 2. Índios do Brasil - História. 3. Livros eletrônicos. I. Portugal, Ana Raquel. II. Hurtado, Liliana Regalado de.

15-20604

CDD: 980.41

CDU: $94(=87)(81)$

Editora afiliada:

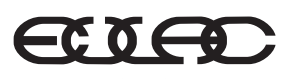

Asociación de Editoriales Universitarias de América Latina y el Caribe

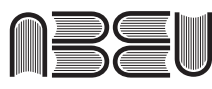

Associação Brasileira de Editoras Universitárias 


\section{SUMÁRIO}

Apresentação 7

PARTE I - Historiografia E REPRESENTAÇÃo DAs POPULAÇÕES INDÍGENAS

Los traslados institucionalizados de población en los Andes prehispánicos. Problemas de fuentes y definiciones 15

Liliana Regalado de Hurtado

Confluência cultural nas Crônicas das Índias 43 Ana Raquel Portugal

Ensino de História indígena: trabalhando com narrativas coloniais e representações sociais 59 Susane Rodrigues de Oliveira

Parte II - NARRativas E iconografia sobre A AMÉRICA INDÍGENA

Idealização, exaltação e degeneração da natureza e dos habitantes do Brasil nos relatos dos viajantes europeus durante o século XVI e início do século XVII 83 Vinícius Pires 
História e memória: os Tupinambá e o seu tempo 121

Ana Paula da Silva

"De diversas lenguas de la Guarani": as representações sobre Guarani e Macro-Jê nas reducciones do Guayra 141 Luiz Fernando Medeiros Rodrigues e Gabriele Rodrigues de Moura

Indígenas americanos na obra de Jacques Arago (1817-1854) 173

Daniel Dutra Coelho Braga

PARTe III - Oralidade E UNIVERSO

CULTURAL INDÍGENA

Narrativas orais e línguas indígenas em Roraima:

educação e preservação da memória e do patrimônio histórico 215

Ananda Machado

A colonização da região amazônica:

as transformações de uma cultura após o contato com a sociedade envolvente 227

Cláudia Nascimento Oliveira, Kelli Carvalho Melo e Adnilson de Almeida Silva

Representação cultural paiter suruí: um ritual de celebração da vida 249 Ananda Catrice Lima da Cunha, Luís Carlos Maretto e Adnilson de Almeida Silva 


\section{Apresentação}

Os povos indígenas têm sido representados ao longo dos séculos através de imagens e escritos que auxiliam na construção de sua memória histórica. No período anterior à chegada dos europeus, pinturas em paredes de templos, esculturas e outros meios foram utilizados para conservar narrativas mitológicas, descrições de costumes e do cotidiano das populações autóctones. No período da conquista, os europeus passaram também a descrever os povos americanos, depreciando-os ou buscando compreender suas características culturais. Nos dias de hoje, produções fílmicas e trabalhos de campo também ajudam a repensar a memória dessas populações. As representações simbólicas da América indígena nos permitem uma aproximação às várias histórias desses povos, que foram contadas de distintas formas de acordo com a época e os interesses vigentes. Estudos atuais resgatam a oralidade desses grupos étnicos descortinando suas crenças, costumes, símbolos, que possibilitam uma aproximação à sua realidade cultural. Nesta obra, os autores recorrem a documentos iconográficos, cronísticos, fílmicos, registros orais, bem como à historiografia, para abordar diferentes temas relativos à representação cultural dos grupos indígenas.

A primeira parte desta obra, composta pelos textos de Liliana Regalado de Hurtado, Ana Raquel Portugal e Susane Rodrigues de 
Oliveira, aborda questões historiográficas e de representação das populações indígenas. Em "Los traslados institucionalizados de poblacion en los Andes prehispánicos”, Liliana Regalado de Hurtado realiza o estudo de como se registraram nas fontes coloniais diversos traslados de população organizados pelas autoridades (curacas e incas) no período pré-hispânico para analisar a problemática levantada pelo estudo de um desses grupos em particular: a população denominada Mitmaqkuna, em língua quéchua. Já Ana Raquel Portugal, em "Confluência cultural nas crônicas das Índias", faz uma análise desse tipo de fonte, explicando suas principais características e finalidades para a compreensão da história do Novo Mundo colonial. São analisadas, especificamente, algumas crônicas produzidas por espanhóis e indígenas dos séculos XVI e XVII para conhecer as práticas culturais vividas por esses homens e que podiam expressar processos de adaptação cultural e resistência. Em "Ensino de História indígena: trabalhando com narrativas coloniais e representações sociais", Susane Rodrigues de Oliveira apresenta algumas reflexões teóricas e propostas metodológicas para o uso de narrativas coloniais no ensino de História indígena na educação básica. Ela propõe o uso de crônicas, cartas, tratados e relatos de viagens que descrevem as sociedades indígenas da América antiga e colonial, mas sabendo qual abordagem utilizar ao trabalhar com essas fontes como objeto de pesquisa histórica, como voz de sujeitos históricos e como discursos carregados de sentidos, valores e representações do passado que precisam ser problematizados.

A segunda parte do livro trabalha com narrativas e iconografia sobre a América indígena. O primeiro texto apresenta relatos portugueses e franceses sobre os indígenas costeiros do Brasil produzidos durante o século XVI. "Idealização, exaltação e degeneração da natureza e dos habitantes do Brasil nos relatos dos viajantes europeus durante o século XVI e início do século XVII”, escrito por Vinícius Pires, busca elucidar que não houve uma constância nesses relatos como comumente aponta a historiografia, a saber, a representação que foi difundida pelos viajantes e religiosos normandos, concedendo características nobres ao índio, e a que foi disseminada 
pelos colonos e religiosos lusitanos, caracterizando-o de maneira depreciativa. Assim, o objetivo principal desse estudo é destacar a alternância nessas narrativas, em contraposição à constância. Já Ana Paula da Silva, em "História e memória: os Tupinambá e o seu tempo", tem como objetivo principal discutir a trajetória de alguns narradores indígenas que dialogaram com os missionários franceses d'Abbeville e d'Évreux no século XVII sobre diferentes aspectos da vida social e cultural dos Tupinambá. A autora argumenta que, diferentemente dos Andes, onde são encontradas versões nativas do processo de colonização, como a crônica de Guamán Poma de Ayala, na América portuguesa existem parcas fontes e iconografias de autoria indígena, salvo alguns documentos como as cartas dos chefes indígenas Potiguara Felipe Camarão e Pedro Poty. Ao evidenciar esses indígenas, ela chama a atenção para as possibilidades de pesquisa a partir de discursos, paroles, biografias indígenas, campos pouco explorados pela historiografia. Luiz Fernando Medeiros Rodrigues e Gabriele Rodrigues de Moura, no texto " "De diversas lenguas de la Guarani': as representações sobre Guarani e Macro-Jê nas reducciones do Guayra", analisam as representações presentes na documentação oficial da Companhia de Jesus, durante a primeira metade do século XVII, onde encontram diversas informações acerca de indígenas que não pertenciam ao grupo étnico-linguístico Tupi-Guarani, moravam dentro das reduções jesuíticas e foram catequizados pelos missionários. Para fazer tal análise, recorreram à documentação escrita pelo padre Antonio Ruiz de Montoya, S.J., que fornece inúmeras informações, a partir de sua visão de mundo sobre esses dois grupos indígenas e como eles se relacionavam entre si ao terem que conviver dentro das reduções. "Indígenas americanos na obra de Jacques Arago (18171854)”, de Daniel Dutra Coelho Braga, analisa a forma como o desenhista francês Jacques Étienne Victor Arago (1790-1854), tripulante da expedição científica de Louis de Freycinet, representou indígenas do Brasil e do arquipélago do Havaí. Arago circunavegou o globo terrestre junto à expedição entre 1817 e 1820, publicando em 1823 uma narrativa epistolar referente à viagem. Também escreveu posteriormente o romance Souvenirs d'un Aveugle, ilustrado com gravuras de 
sua autoria. No intuito de compreender as funções e concepções que regem tais representações, o autor estabelece, através dos pressupostos da história cultural conforme elaborada por Roger Chartier, comparações com outras produções da época. Destacam-se, nesse sentido, o relatório científico do próprio Freycinet, bem como obras do também viajante Ferdinand Denis e do naturalista Bernardin de Saint-Pierre, as quais representam tendências preponderantes na forma como nativos americanos eram representados na cultura europeia, em suas vertentes iluminista e romântica de tradições textuais, estruturadas em torno de ideias específicas de natureza, cultura e civilização. Assim, Daniel Braga compreende a obra de Arago não como um todo homogêneo, mas como um corpus complexo, por vezes com elementos divergentes, no qual cada representação exerce funções sociologicamente diferenciadas, variáveis de acordo com o posicionamento social do autor, sobretudo em relação ao Estado francês.

A última parte desta obra possui trabalhos relativos à oralidade e ao universo cultural indígena. "Narrativas orais e línguas indígenas em Roraima: educação e preservação da memória e do patrimônio histórico", de Ananda Machado, discute a oralidade e as línguas indígenas como memória histórica dos povos. Segundo a autora, as narrativas mitológicas, as descrições pelos senhores(as) da memória sobre seus costumes e os desafios do cotidiano existem desde antes do período inicial da colonização e reforçam suas características culturais, linguísticas e as representações simbólicas. Os estudos da pesquisadora com os indígenas Macuxi e Wapichana em Roraima levaram em conta narrativas referentes a documentos, peças e pinturas arqueológicas, bem como a história social das línguas, as crenças, as danças e o artesanato indígena. No texto, a autora propõe a construção de processos de educação e preservação patrimonial nas escolas e comunidades indígenas. Cláudia Nascimento Oliveira, Kelli Carvalho Melo e Adnilson de Almeida Silva, em "A colonização da região amazônica: as transformações de uma cultura após o contato com a sociedade envolvente", analisaram a etnia Suruí, vivenciando seus costumes e as transformações no modo de vida da aldeia Apoena Meireles em virtude do contato constante com o homem branco. Mesmo 
com as mudanças, os autores afirmam que muitas tradições ainda estão evidentes e presentes no dia a dia da aldeia. No último texto desta obra, Ananda Catrice Lima da Cunha, Luís Carlos Maretto e Adnilson de Almeida Silva apresentam seu estudo sobre esse mesmo grupo amazonense, mas buscando a "Representação cultural paiter suruí”. Para compreender essa construção de signos nos espaços culturais indígenas, os autores realizaram trabalho de campo na aldeia Sete de Setembro, localizada no Mato Grosso. Partindo da análise do ritual indígena da festa do Mapimái ou de Criação do Mundo, os autores puderam identificar como essa etnia continua mantendo suas origens mesmo com a forte influência do homem branco. Temos, assim, dois trabalhos sobre o grupo Suruí, que mostram seu universo simbólico e como essa etnia vem redefinindo seus espaços para preservar as tradições mesmo em contato com o homem branco.

A obra aqui apresentada destaca a permanência da problemática da representação e compreensão da realidade das populações aborígenes desde a época da conquista e colonização até nossos dias. Este conjunto de trabalhos mostra que, apesar de obedecer a lógicas diferentes, as representações aborígenes se imbricaram com as ocidentais mesmo que, durante vários séculos, tenha havido uma forte e constante tensão entre ambas. Essa relação levou historiadores, antropólogos e linguistas, a partir de diferentes perspectivas e com diferentes tipos de fontes, a voltarem com novo ímpeto a remexer nos discursos contidos nos testemunhos para tratar de encontrar o tradicional e o novo, o permanente e o que mudou nas representações e na identidade de nossas populações nativas, enfatizando sua contribuição cultural e social à configuração de nossas sociedades modernas e contemporâneas.

Esperamos que nossos leitores encontrem nestas páginas não simplesmente informação, mas também uma fonte de reflexão, análise e discussão. 


\section{Parte I \\ HISTORIOGRAFIA E REPRESENTAÇÃO DAS POPULAÇÕES INDÍGENAS}




\section{LOS TRASLADOS INSTITUCIONALIZADOS DE POBLACIÓN EN LOS ANDES PREHISPÁNICOS. PROBLEMAS DE FUENTES Y DEFINICIONES}

Liliana Regalado de Hurtado*

Como es conocido, hubo en los Andes prehispánicos diversos traslados de población organizados por las autoridades (curacas e incas) que estaban orientados a cumplir propósitos diversos como la expansión de fronteras internas y externas, el control de diferentes ambientes ecológicos y la obtención de ciertos productos agrícolas, manejo de excedentes etc. Esas poblaciones se identificaban con nombres como mitay"uq y mitmaqkuna aunque hubo en las características y funciones específicas de ambas, notables diferencias a la luz de lo que se desprende de las diferentes fuentes a disposición. En este trabajo vamos a referirnos brevemente a la problemática que plantea el estudio de la población mitmaqkuna. Si en el caso de los mitay"uq estamos ante traslados de mano de obra temporales (durante periodos de duración variable); los mitmaqkuna han sido definitivamente caracterizados como grupos trasladados de forma permanente fuera de sus lugares de origen para cumplir tareas diversas y no exclusivamente productivas.

\footnotetext{
* Profesora de Pontificia Universidad Católica del Perú.
} 


\section{Premisas y repaso general del asunto}

Pero para tratar de lograr más que una definición, la descripción funcional de lo que fue el sistema de mitmaqkuna en el periodo prehispánico y, particularmente en la época del dominio incaico, es preciso revisar no sólo la documentación que da cuenta sobre el asunto y que fue elaborada durante la época colonial sino establecer algunos presupuestos que nos sirvan de punto de partida para alcanzar a describir al sistema y su modo de operar. La primera premisa es que estamos frente a un sistema de desplazamientos poblacionales regulados por el poder. El segundo presupuesto remite a su originalidad es decir, que dicho sistema de traslados es específicamente andino y, por consiguiente, no resulta plenamente identificable con otras formas de desplazamientos o movimientos de población tipo colonias, conocidos de antemano por los españoles pues, al parecer, no hubo en el Occidente antiguo y moderno desplazamientos demográficos equivalentes a los mitmaqkuna prehispánicos, tal como se describe en las fuentes, pese a que en la España de la reconquista se conoció el establecimiento de poblaciones en los territorios que se iban ganando a la ocupación musulmana que, sin embargo, no constituye un modelo equiparable al fenómeno andino de traslado sistemático y organizado de poblaciones para diversos fines, la mayor parte de las veces complementarios entre sí, conforme lo veremos más adelante.

También debe descartarse que la identificación de estos desplazamientos tal y como lo consignaron los españoles pueda verse como similar a un modelo más antiguo tomado, por ejemplo, del Antiguo Testamento ya que en ese texto sagrado de la cristiandad las referencias a los extranjeros asentados en poblaciones diferentes a sus lugares de origen remiten a casos individuales y situaciones muy concretas relacionadas con el ambiente sociocultural del lugar. Se considera al foráneo o extranjero de manera individual y no colectivamente y se da cuenta de casos específicos por ejemplo cuando algunos extranjeros se integraban en la comunidad como huéspedes mientras que otros, tras el contacto con los oriundos se casaban con ellos, pese a restricciones existentes al respecto que paulatinamente 
se tornaron más severas. ${ }^{1}$ Además, las distinciones entre extranjeros y lugareños no se basaban en aspectos biológicos o racistas sino en un criterio religioso: la acción de Dios con su pueblo y así se distingue entre el extranjero (nŏkrî) que tiene otra religión y el (ger) que se integra al pueblo y reconoce a Yavé como a su Dios. Pero esta diferenciación no significó que los foráneos fueran rechazados o perseguidos (Caero, 2004, p.89-90).

El tercer presupuesto es que se debe discutir la validez absoluta de la idea del enraizamiento o patrón de asentamiento fijo de las poblaciones andinas prehispánicas en un territorio, dado que ello obedece a una tradición historiográfica fundada en las crónicas y canonizada por ejemplo por un Cunow (1933 [1896]) quien asoció ayllu con marca (territorio del ayllu). Asimismo, se tiene que poner en tela de juicio el criterio, cuyo origen está también en las crónicas, de que hubo necesariamente una evolución que partió de un patrón de movilidad poblacional identificable con nomadismo a otro de sedentarismo absoluto. Lo que significaría que las organizaciones étnico-señoriales y después los incas habrían seguido, en ese orden, a las antiguas behetrías de un Garcilaso y también, en cierto modo, de un Cieza de León.

Pero si por el contrario la historiografía actual admite la territorialidad discontinua, la movilización que importa la existencia de los mitmaqkuna debería verse como muy natural y no como una excepción a la discutible regla que adscribe población siempre estable en un territorio fijo en los Andes. Recordemos que Murra indicó en su oportunidad que las movilizaciones de población prehispánicas parecen haber sido más frecuentes en los Andes de lo que nos imaginamos y más bien fueron un fenómeno continuo aún antes de la expansión inca. Lo atribuye en parte al esfuerzo de las poblaciones altiplánicas por ampliar sus medios de subsistencia, incorporando oasis costeños, valles serranos, punas y yungas amazónicas en un solo sistema demográfico, productor y político (Murra, 1990, p.15). Además, se ha destacado que el grado de multietnicidad en los Andes prehispánico y colonial debe entenderse dependiente de su contexto el mismo

1 Véase Deuteronomio, 23. 
que puede estar marcado por un nivel mayor de territorios continuos (franjas étnicas que abarcaban una amplia gama de microclimas) ocupados por ayllus que reconocen un cierto parentesco común y la misma autoridad y otro nivel inferior en el que los ayllus componentes de cada franja están entremezclados, cada uno con sus territorios discontinuos. Contándose también con que las "grandes naciones" contaban con población mitmaqkuna instalada en asientos multiétnicos como ocurrió en Cochabamba, Pocona y Chuquisaca (Harris, 1997, p.358-359) por citar algunos ejemplos.

Conforme a lo dicho, la especificidad o excepcionalidad que supone la presencia de los mitmaqkuna en el seno de las organizaciones andinas debería buscarse entonces no en el hecho mismo de la movilización de la población sino más bien en que supuso la disposición de una energía adicional y estable a favor de las autoridades (curacas o incas) más allá de las formas corrientes pero limitadas de la mita. En esa misma línea está el propósito de acceder (más allá de cualquier otro tipo de acuerdo o negociación) de manera estable a determinados recursos fuera de los núcleos (lejos o cerca de ellos). Debe tomarse en cuenta que reasentamientos importantes parecen haber ocurrido al finalizar la fase cultural Huari (Tiahuanaco expansivo) hacia el siglo XII, con el abandono de antiguos sitios y la aparición de nuevos estilos cerámicos. (C.fr. Ellefsen, 1978, p.77-78). Siguiendo más o menos esta línea, cuando Villarías y Maman estudiaron la presencia incaica en Cochabamba partieron de la idea de que los incas habían adaptado políticas anteriores de controles ecológicos pero también crearon nuevas colonias de mitmaqkuna con el propósito de consolidar su dominio y proteger fronteras, sobre todo, en aquellos territorios que habían dominado con mayor dificultad. Sin embargo, fueron claros al manifestar que el caso estudiado indicaba que también se perseguía por lo menos en ciertos lugares - claros propósitos económicos como la obtención de volúmenes de producción suficientes para sostener material e ideológicamente al poder incaico a cambio de contraprestaciones a las poblaciones movilizadas lo que eventualmente redundaría en su afirmación identitaria frente al poder central aunque sin cuestionarlo, necesariamente (Villarías; Maman, 1998, p.633-634). 
Las funciones de carácter religioso, estratégico-militar y político que se ha venido reconociendo a muchos grupos de mitmaqkuna serían consecuencia, en muchos casos, de requerimientos locales y también del poder central cuzqueño para la consecución de los propósitos mencionados en el párrafo precedente. De cualquier manera, el origen de los traslados de población que conocemos con el nombre de mitmaqkuna, debe presumirse en épocas anteriores al dominio incaico, aunque evidentemente sin todas las connotaciones que le son características en dicho período estatal..$^{2}$ En efecto, alguna referencia acerca de su existencia puede ser hallada en la memoria oral andina que remite a épocas anteriores al dominio incaico en los Andes y que, posteriormente, estaría relacionada con el proceso expansivo del Tahuantinsuyo. Asunto sobre el que nos ocuparemos en el ítem siguiente. Es plausible considerar que en la medida de que se consolidó el poder y la organización del estado incaico la élite cuzqueña pudo controlar mayor cantidad de mano de obra genérica y especializada y, por consiguiente, también muchos más recursos en cantidad y variedad lo que significaría que las aparentemente primigenias funciones de los mitmaqkuna dirigidas, sobre todo al control vertical y horizontal de ecologías diferentes, se habrían ido acentuando y haciéndose más complejas, es decir, ampliándose a otras de carácter marcadamente religioso y político como fenómeno vinculado al proceso de mayor expansión del dominio incaico. Dicho de otra manera, al aumentarse la escala de los controles de diversos microclimas bajo los términos de potencial humano - recursos - y manejo de excedentes, el estado incaico sistematizó estos desplazamientos de población

2 Rostworowski, por ejemplo, no duda de su existencia anterior a los incas y toma como ejemplo los asentamientos de los Lupaqa en la costa a distancia de su núcleo y presume que el sistema de mitmaqkuna fue practicado en la época del predominio Huari. Añade que en esos casos la misión original era trabajar la tierra pero que en la época de los últimos incas esto se transformó produciéndose traslados poblacionales masivos por lo que los mitmaqkuna pasaron a ser empleados como fuerza de trabajo a gran escala para realizar las obras estatales de gran envergadura. Cita lo referido por Wachtel en 1980 acerca de lo ocurrido en el valle de Cochabamba (Rostworowski, 1988, p.22). 
y los ordenó hacia los fines de su política general pese a que las crónicas elaboradas por los españoles durante la colonia apuntan a señalar que en las épocas más tempranas de la existencia de la organización incaica la población mitmaqkuna estuvo vinculada al poder ejercido por aquellos a quienes los cronistas llaman sinchis, cuya labor bélica habría marcado las funciones político-militares de los mitmaqkuna, que en las fuentes del XVI identificaron como de frontera.

La innovación introducida por el Tahuantinsuyo en el sistema de mitmaqkuna sería fundamentalmente haber tomado bajo su control a estos grupos humanos transpuestos afianzando la autonomía de los mismos y, a través de ellos, la del propio estado frente a los gobiernos locales procurando así el establecimiento de redes cada vez más amplias de acceso a excedentes e intercambios bajo su control directo. De esta manera, entendemos que el estado incaico se situó sólidamente por encima del tradicional ideal de autosuficiencia perseguido permanentemente por las etnias y curacazgos andinos. De cualquier manera, es difícil establecer dónde y en qué oportunidades los incas hicieron suyos traslados de poblaciones efectuados antes de su dominio o en qué medida la presencia de mitmaqkuna significaba en determinados sitios algo nuevo. Asimismo, es interesante destacar que desplazamientos de grupos identificados como mitmaqkuna dan cuenta de su presencia en prácticamente todo el territorio andino. Ejemplo, entre tantos, son el asentamiento de Pueblo Viejo-Pucará en el valle de Lurín, cuya población mitmaqkuna parece haber procedido de un núcleo situado en Caringa en Huarochirí (Makowski; Vega Centeno, 2004, p.681) y la minuciosa ubicación de los numerosos grupos de mitmaqkuna en el Chinchaysuyo realizada por Lorandi y Rodríguez. ${ }^{3}$

3 Al respecto, véase Lorandi y Rodríguez (2003). 


\section{La imagen ofrecida por las fuentes documentales tradicionales y una interpretación de la institución de los mitmaqkuna en el contexto colonial}

Pocos años después de que el propio Francisco Pizarro prestara atención a la existencia de la población mitmaqkuna un funcionario eclesiástico, el provisor Luis de Morales, describió al sistema como una institución incaica (apud Ravi, 2007, p.25) a pesar de lo cual no debemos perder de vista que durante el periodo colonial la apelación a la figura del inca y al estado incaico como generadores de todo orden u organización se constituyó - tanto entre indígenas como entre españoles - en legitimadora del antiguo ordenamiento andino, pese a que paralelamente la administración española y un gran número de cronistas solían hablar de la tiranía del gobierno incaico. De esta forma, "desde tiempo del Inca o puestos por el Inca" fueron argumentos usados durante la conquista y primeras etapas de la colonización, tanto por los propios hombres andinos como por los conquistadores españoles, para sustentar reclamos o mantener una situación anterior a la presencia española en los Andes en tanto era vista como favorable para individuos o grupos dentro del nuevo orden colonial que se iba estableciendo.

En materia de la movilización y asentamientos poblacionales en la modalidad de mitmaqkuna hay que tomar en cuenta que la información disponible que nos permite dibujar cómo funcionaba el sistema viene, en elevada proporción, de visitas y litigios por el acceso a tierras, mano de obra y, evidentemente también el sostenimiento y construcción del poder. También hay que contemplar - como la hizo Ravi - que las nuevas fuerzas coloniales fueron cambiando la naturaleza de la movilidad andina y que el interés oficial por los mitmaqkuna tuvo que ver con el hecho de que su existencia afectaba a la encomienda es decir, una importante institución virreinal (Ibid., p.36 et seq.) y no sólo eso, también tenía que ver - desde la perspectiva de las autoridades nativas - con el control de población y de ecologías que, de suyo, eran fundamentos del poder de las autoridades andinas tradicionales. Además, claro está, afectaba la política colonial de 
concentración de la población a través de las reducciones o "buenos pueblos" para los indios.

Partiendo del significado del nombre mitmaqkunaen quechua, cronistas como Cieza y Murúa coinciden en afirmar que MITIMAS o MITIMAES4 "son gente transpuesta de una tierra en otra" (Cieza, 1967 [1553], p.74; Murúa, 1946 [1590], p.45). Más adelante, encontramos algo más que esta aseveración ya que las diferentes fuentes y en particular las crónicas, subrayaron el carácter obligatorio de dichos traslados: para Cieza, "los que son transpuestos" y para Murúa "gente mudada", que dejan implícita la noción de una autoridad o mandato detrás de estos cambios de residencia y no un movimiento voluntario. Si bien es cierto que los desplazamientos de población - tanto de forma individual como grupal - pueden, en general, ser entendidos como movimientos espontáneos de los individuos o grupos por motivaciones diversas tales como trabajo, apropiación de recursos, crecimiento demográfico etc., en una organización compleja y estructurada como la incaica y en las organizaciones de corte estatal anteriores, esas movilizaciones naturales parece que alcanzaron una formalización que las ligaba a los centros de poder y por tanto debieron adquirir un orden o procedimiento quedando también sujetas a restricciones. Naturalmente, acusando mayor precisión, Diego González Holguín en su Vocabulario general indica para el sustantivo MITMAQ el significado de "advenedizo, avecindado" (González Holguín, 1952 [1608], p.244), lo que añade a lo señalado otras particularidades: la condición de forastero y el carácter de permanencia, lo que permite distinguir al mitmaq de otros individuos que practicaban la movilidad puesto que señala para advenedizo también otras denominaciones como Huahuaruna o Purik, entre otros lo que permite hacer diferencias con la población mitmaqkunay, naturalmente, con otras connotaciones. Estaríamos en condiciones de afirmar que en el lenguaje de los indígenas se distinguía entre el "recién llegado, ajeno al ayllu" es decir, forastero o mitmaqkuna del "recién llegado ligado a la comunidad", en este caso un originario del lugar que regresa como

4 Expresiones castellanizadas. 
también el recién nacido (González Holguín, 1901 [1608], p.226; Santo Tomás, 1951 [1560], p.135-133). Domingo de Santo Tomás permite corroborar estas reflexiones cuando en su Lexicón distingue entre tiapococ "extraño o extranjero; forastero que se ha de ir" y mithma o mithima "forastero o extranjero que está de asiento" (Santo Tomás, 1951 [1560], p.135-138, 390).

De otro lado, tenemos el empleo del término yacha que, aparentemente, en la visita a la etnia de los chupachu en Huánuco se empleó como denominación étnica aplicada a un grupo de mitmaqkuna aparentemente identificable con los orejones cuzqueños ${ }^{5}$ cuando más bien pareciera que yacha es usada por los informantes como un apelativo genérico que englobaría a gente procedente de diferentes lugares diferenciables, en conjunto, de los mitmaqkuna orejones aunque ambos grupos es decir, los yacha y mitmaqkuna habrían sido puestos en Huánuco por los incas. Al respecto, hay que tomar en cuenta que el término yacha tiene un origen y significado que deben merecer nuestra atención así que siguiendo a César Itier (1993) diremos que:

1. Yacha es una raíz transitiva quechua. En el Cuzco tanto en tiempos de González Holguín como ahora significa saber a secas. El vocabulario anónimo de la lengua general de 1586 y los modernos diccionarios de quechua "chanca", "huanca" y ancashino añaden a la glosa saber las de morar, residir.

2. La tarea de remontarse a la historia de la lengua hasta la época prehistórica para postular una unidad de significación para la citada raíz es posible sin peligro de especulación y así yacha es analizable como descendiente de un derivado prehistórico de $y a-: y a-\hat{c} a-$.

5 Así como en el valle Calchaquí el grupo identificado como ingamana estaría conformado por mitmaqkuna incaicos y el nombre aludiría a una situación específica “camayos oficiales del inca” (Williams, 2000, p.69). Pese a que la traducción de la autora citada no parece correcta ya que, en todo caso, ingamana sería un nombre propio del habla diaguita y su significado sería mucho más genérico: "gente del inca" (Comunicación personal de Rodolfo Cerrón Palomino). De todas maneras, ingamana, lo mismo que yacha, no remitiría a una identificación étnica. 
3. La raíz ya, aparece en varios lexemas verbales modernos que expresan movimiento por lo que parece haber significado ir, moverse, entrar, salir etc. y ĉa fue un sufijo que la acción expresada por el verbo se realizaba de manera total o completa.

4. En cuanto a la aparente diversidad de los derivados de yaĉa en la época colonial estos se pueden reducir a una anterior unidad de significado y así:

El movimiento de "llegar a un término", es decir, "adecuarse a un límite", se puede efectuar tanto de manera lineal, de un punto a otro, como tridimensional: "ocupar todo un espacio". En el primer caso cobra el sentido de "saber" yacha expresó en algún momento de la historia de la lengua la idea de una adecuación intelectual del sujeto al objeto del conocimiento. En el segundo, cobra el sentido de "morar, residir”. (Itier, 1993, p.97-101)

Visto lo anterior, el nombre yacha debe entenderse como un original y ocasional equivalente a mitmaqkuna que la información colonial y, a partir de ella la historiografía, erróneamente convirtieron en la denominación de un supuesto grupo étnico. Así pues, es posible advertir que en términos de las lenguas andinas prehispánicas se pude diferenciar entre una visita esporádica o temporal y un asentamiento permanente de uno o varios individuos dentro de una población. Algo más, lo que parece importar dentro del viejo orden andino no es el simple cambio de residencia sino el insertarse dentro de un territorio y población conservando su condición de extranjero. El cambio de residencia tenía naturalmente implicancias en el orden de lo social y económico en tanto consideremos las relaciones de reciprocidad que regían al interior de los ayllus y grupos étnicos ${ }^{6}$ lo que confiere a los traslados bajo la modalidad de mitmaqkuna una complejidad e importancia singulares.

6 Isbell (1974, p.110-111), en un trabajo etnológico en la aldea de Chuschi, provincia de Cangallo encontraba que, aún en la década de 1970 se entendía por "comunero" al individuo que se identificaba con y participaba en la comunidad tradicional corporada y habitaba en una de las dos mitades de la comunidad. En 
Los relatos y documentos administrativos del siglo XVI, incluyendo textos tempranos, mencionan a los mitimaes o mitmaqkuna identificándolos como gente foránea establecida en lugares determinados por disposición de la autoridad (particularmente el Inca). Es interesante mencionar que el cronista Diego Fernández destaca el carácter coercitivo de la movilización de la población como mitmaqkuna considerando que ello era expresión de un claro propósito de los incas de hacerse fuertes en los Andes frente a las autoridades curacales (Fernández, 1963 [1571], Segunda Parte, Libro III, cap. II). En cambio, en el siglo XVIII no se los menciona mayormente y, en su defecto, será más abundante la información que se refiere a foráneos o forasteros. Ello indica la pérdida de vigor y hasta la desaparición del sistema original de desplazamientos organizados por el poder propio del periodo prehispánico. Ejemplo de lo dicho en primer término lo encontraremos en la visita a Cajamarca de 1540 cuando se alude a los mitmaqkuna de los tambos:

Ansimismo, fueron preguntados por el dicho señor visitador, con la dicha lengua, y en presencia de mí el dicho escribano, a los dichos señores de Caxamarca qué mitimaes había en esta dicha su tierra que no fuesen sus subjetos. Los cuales dijeron que los caciques Guamane Chilcho, que son en los términos de Los Chachapoyas, servían al inga en los dichos tambos de Caxamarca. (Espínoza, 1967, p.38)

Es importante tomar en cuenta que en las primeras décadas del siglo XVII cronistas como Garcilaso y Guamán Poma no solo recogen y detallan lo consignado anteriormente en otras fuentes sino que, como en el caso del cronista indio nombrado se entiende el término como extranjero de manera bastante genérica. En el caso de Garcilaso tenemos que, luego de mencionar en el Libro Séptimo a los mitmaqkuna y explicar más bien brevemente cómo operaba el sistema, trata

contraposición al foráneo oqala (pelado o desnudo), que no pertenece a la comunidad o se ha despojado (pelado) de su identidad tradicional y casi como regla general no vive en ninguna delas dos mitades. Entendemos que tal categorización $\mathrm{y}$ diferencias siguen teniendo vigencia hasta ahora. 
extensamente sobre ellos en el capítulo I de la mencionada parte bajo el título "Los incas hacían colonias; tuvieron dos lenguajes". Dice textualmente lo siguiente: "Los Reyes Incas trasplantaban indios de unas provincias a otras para que habitasen en ellas; hacían lo por causas que les movían, unas en provecho de sus vasallos, otras en beneficio proprio, para asegurar sus reinos de levantamientos y rebeliones" (Garcilaso, 1959 [1609], p.371). Asimismo, explica con claridad las características de los traslados forzosos de la manera siguiente:

Mudaba, [el inca] cuando era menester, los habitadores de una provincia a otra; proveían les de heredades, casas, criados y ganados, en abundancia bastante; y en lugar de aquellos llevaban ciudadanos del Cozco o de otras provincias fieles, para que, haciendo oficios de soldados en presidio, enseñasen a los comarcanos las leyes, ritos y ceremonias y la lengua general del Reino. (Ibid., p.248)

Debe tomarse en cuenta que ya durante la primera década del siglo XVII el término mitmaqkuna identifica a una movilización forzada de poblaciones y a su reasentamiento como colonias, en el sentido antiguo del término empleado en la cultura occidental. Sobre todo, si nos atenemos al hecho ampliamente estudiado y debatido de que las crónicas en general y, particularmente la de Garcilaso, siguieron los patrones clásicos en forma y contenido, de manera tal que así se explica muy bien por qué se denomina colonias al sistema de mitmaqkuna. Es más, al referirse Garcilaso a estas poblaciones en el capítulo en el que se trata sobre las lenguas manejadas por los incas vemos que el cronista mestizo está aplicando el modelo de pax romana a la organización incaica y, en tal sentido, colonias y una lengua general serían instrumentos eficaces e indispensables para una organización semejante a los imperios antiguos. Además, presenta un primer tipo de mitmaqkuna: político-militar. Este primer modelo de "colonias" se muestra de forma más detallada cuando reitera que:

Trasplantaban también por otro aspecto, y era cuando habían conquistado alguna provincia belicosa, de quien se temía que, por 
estar lejos del Cozco y por ser de gente feroz y brava, no había de ser leal ni había de querer servir en buena paz. Entonces sacaban parte de la gente de aquella tal provincia, y muchas veces la sacaban toda, y la pasaban a otra provincia de las domésticas, donde viéndose por todas partes rodeados de vasallos leales y pacíficos, procurasen ellos también ser leales, bajando la cerviz y el yugo que ya no podían desechar. (Ibid., p.373)

No añade nada nuevo Garcilaso a lo dicho por anteriores cronistas particularmente, Cieza de León, en quien se apoya en esta parte pero sigue su explicación de la manera siguiente:

Los Incas, yendo conquistando, hallaban algunas provincias fértiles y abundantes de suyo, pero mal pobladas y mal cultivadas por falta de moradores; a estas tales provincias, porque no estuviesen perdidas, llevaban indios de otras de la misma calidad y temple, fría o caliente, porque no se les hiciese de mal la diferencia del temperamento. (Ibid.)

Se está refiriendo el autor a un segundo tipo de "colonia" aquella destinada a conseguir un adecuado equilibrio entre población y territorio-producción de recursos, señal asimismo, de la racionalidad de la organización incaica. En este segundo modelo de "colonización incaica" presenta unas variantes específicas: "Otras veces los trasplantaban cuando multiplicaban mucho de manera que no cabían en sus provincias; buscaban les otras semejantes en que viviesen; sacaban la mitad de la gente de la tal provincia, más o menos, la que convenía" y viceversa: "sacaban indios de provincias flacas y estériles para poblar tierras fértiles y abundantes". Finalmente, explica el objetivo de esa política incaica expresada en el segundo modelo de colonización al señalar que:

Esto hacían para beneficio, así de los que iban como de los que quedaban, porque, como parientes, se ayudasen con sus cosechas los unos a los otros, como fue en todo el Collao, que es una provincia 
de más de ciento y veinte leguas de largo y que contiene en sí otras muchas provincias de diferentes naciones, donde, por ser la tierra muy fría no se da el maíz ni el uchu, que los españoles llaman pimiento, y se dan en grande abundancia otras semillas. (Ibid., p.371-372)

La forma como Garcilaso presentó al sistema de mitmaqkuna deja en segundo plano el componente de ejercicio de poder de curacas o incas que las movilizaciones de tal naturaleza requerían, antes y durante el predominio incaico, destacando más bien el propósito de búsqueda de equilibro hombre-tierra (recursos) por encima del objetivo político-militar. También hay que llamar la atención que en el capítulo de Los comentarios reales que estamos reseñando las tradiciones y el escenario del Collao adquieren protagonismo cuando de explicar el funcionamiento del sistema de "colonias" se refiere. Siguiendo a Cieza de Leónquien también dio el crédito a los incas en lo que al traslado de poblaciones se refiere y con el propósito de efectuar controles ecológicos. Añade que:

De todas aquellas provincias frías sacaron por su cuenta y razón muchos indios y los llevaron al oriente dellas, que es a los Antis, y al poniente, que es a la costa del mar, en las cuales regiones había grandes valles fertilísimos de llevar maíz y pimiento y frutas, los cuales tierras y valles antes de los Incas no se habitaban; estaban desamparados como desiertos, porque los indios no habían sabido ni tenido maña para sacar acequias para regar los campos. Todo lo cual bien considerado por los reyes incas, poblaron muchos valles de aquellos incultos con los indios de una mano a otra más cerca les caían; dieron les riego, allanando las tierras para que gozasen del agua, y les mandaron por ley que se socorriesen como parientes, trocando los bastimentos que sobraban a los unos y faltaban a los otros. También

7 Resulta interesante advertir que en este fragmento el cronista implícitamente muestra el modelo del control ecológico basado en los archipiélagos multiétnicos de larga data en los Andes prehispánicos y particularmente en las sociedades altiplánicas. 
hicieron esto los Incas por su provecho, para tener renta de maíz para sus ejércitos, porque como ya se ha dicho, eran suyas las dos tercias partes de las tierras que sembraban; esto es, la una tercia parte del Sol y la otra del Inca. (Ibid., p.372)

Es evidente de que detrás de todo lo dicho queda bien perfilada la idea de que existió una ecuación en la organización andina prehispánica conformada por los siguientes términos: poder, tecnología y controles ecológicos. ${ }^{8}$ De todas maneras resulta interesante señalar que contemporáneamente a la versión de Garcilaso el cronista indio Guamán Poma de Ayala definía a los mitmaqkuna simplemente como extranjeros y aplica también el mismo nombre a los españoles residentes fuera de sus lugares de origen.

Que los dichos padres dotrinantes estrangeros, que en la lengua de los yndios se llama mitimac de Castilla, todos no se puede llamarse propetario, aunque sea hijo de español como no sea hijo de yndio. Y ací de nenguna manera es propetario los padres de las dotrinas deste rreyno. Todos son ynteren[os] porque solo los yndios son propetarios ligítimos que Dios plantó en este rreyno. Y ci acaso fuera a España un yndio, fuera estrangero, mitima, en España. (Guamán Poma, 1980 [1613?], p.657)

Es más, al intentar establecer su propia genealogía al pie del dibujo 286 dice: "Poma, del pueblo de Chipao, del ayllu Allauca Guánoco, mitmaq, descendiente de inmigrantes de la era de los Yngas, pisqakamachikuq, mandoncillo de cinco indios tributarios", volviendo de esta manera a emplear el término como sinónimo de extranjero o foráneo. Esa condición se reflejaba, según el citado cronista en la facultad que tenían de usar su propio vestuario "y en el cierra puedan traer áuito y trage de yndio serrano y los yungas traygan su áuito yunga mitima" (ibid., p.873). ${ }^{9}$

8 Véase Regalado (1984).

9 Aunque este criterio de diferenciación étnica fue usado por todos los cronistas no necesariamente podría ser indicio de que ese fuera un parámetro de distinción 
En lo que se refiere a la antigüedad de tales formas de movilización - asentamiento, ya se ha indicado su existencia preincaica y varias fuentes y autores remiten su empleo por el estado incaico al periodo de Túpac Inca Yupanqui lo que tendría su explicación en el hecho de que, en conformidad con la tradición oral, la figura de este Inca estaba ligada a la gran expansión incaica. Pues si bien Guayna Cápac completa la expansión territorial, Túpac Inca parece sentar las bases de la misma. La implantación del sistema de mitmaqkuna relacionada a la figura de Túpac Inca deberá entenderse naturalmente derivada de la cosmovisión y del pensamiento religioso que configuraba la memoria oral de la población andina prehispánica en ciclos arquetípicos vale decir en etapas o ciclos míticos dentro de los cuales se coloca el origen y explicación de la realidad y los acontecimientos. Prueba de que el origen de los mitmaqkuna dado por los cronistas resulta la versión historizada de otra diferente y más bien de carácter cíclico, que por lo tanto no debe referirse a acontecimientos sino a categorías, es la referencia de Cieza, quien dice haber escuchado a algunos indígenas señalar a Wiracocha como el creador del sistema de mitmaqkuna (Cieza, 1967 [1553], p.78). La vinculación de la existencia del sistema a una explicación de carácter arquetípico debiera necesariamente llevarnos a un relato mítico o leyenda más precisos, capaces de dar cuenta de su origen; cuando menos debiéramos dar con un contexto legendario (religioso) que otorgue sentido a su presencia como institución dentro de las sociedades andinas. En esa línea consideremos en primer lugar que correspondió a la curiosidad europea y a su afán de abolir lo que a su entender era profano, recoger información sobre todo a partir de la época de Túpac Inca, arquetipo del último de los ciclos a que nos referíamos antes: ${ }^{10}$

propio de las poblaciones andinas y pudieron haber respondido a un criterio vigente en el pensamiento occidental de la época.

10 Otro nivel se encontraba en proceso de formación cuando se dio la invasión hispana, según el autor citado. 
El origen de los mitmaqkuna ofrecido a los cronistas por los informantes andinos correspondía a una visión cíclica que, evidentemente, no hacía referencia a acontecimientos sino a categorías. Por eso es que seguramente Cieza señalaba haber escuchado por boca de algunos indios adjudicar a Wiracocha la paternidad del sistema. (Ibid., p.78) ${ }^{11}$

Pero en realidad, no importa realmente en qué "momento" coloque la memoria oral incaica al sistema, ni tiene mayor trascendencia pretender establecer la cronología exacta de su origen estando plenamente evidenciada su existencia histórica, según testimonios tempranos y tardíos recogidos durante el periodo de la colonización y las evidencias de la permanencia de los mitmaqkuna en los Andes tras la llegada de los españoles. De vincularse el origen del sistema de mitmaqkuna con algún tipo de explicación arquetípica ella tendría que tener connotaciones religiosas que, hasta el momento no son conocidos. Asimismo, a priori debe contemplarse que el incremento notable de la población mitmaqkuna durante el dominio incaico tendría que ver con la expansión misma del llamado Tahuantinsuyo. De todas maneras los fuertes matices religiosos que se observan en la actuación de los mitmaqkuna y hasta la especialización de algunos grupos en este campo de acción, parecen expresarse por ejemplo en el encargo de cuidar las momias de los incas. ${ }^{12}$ Pero según lo recogido por los cronistas la finalidad de estos traslados de población se hacía básicamente para la consecución de dos objetivos:

1. colonización, entendida como el poblamiento de zonas recién conquistadas por los incas buscando asegurarlas, además de procurar el equilibrio hombre-tierra. Así Garcilaso menciona que Mayta Cápac envió mitmaqkuna a Moquegua atendiendo el pedido de sus capitanes "porque les pareció tierra fértil y capaz de mucha más gente de la que tenía [...]” (Garcilaso, 1959 [1609], p.137); y

11 Murúa (1946 [1590], p.64) señala a Túpac Inca como el creador del sistema.

12 Véase por ejemplo Ortiz de Zúñiga (1967-72 [1562], tm.I, p.33). 
2. control de la población, no solamente para establecer un balance entre densidad de población y potencial ecológico en una localidad sino también para realizar actividades de carácter bélico. Citaremos nuevamente al Inca Garcilaso cuando al referirse al dominio incaico en el Colesuyo y específicamente en Moquegua, completa sus anteriores afirmaciones diciendo que "convenía dejar en ella presidio para asegurar lo ganado y para cualquier otra cosa que adelante sucediese” (ibid.). Es evidente que a la luz de lo señalado por el autor de Los comentarios reales todos estos traslados no eran espontáneos sino más bien resultado directo de claras políticas estatales incaicas y reflejo de un manejo ordenado y muy racional del territorio, los recursos y la población al mismo tiempo que se ejercía un control político eficaz por parte del estado incaico. Todo un modelo de planificación si se considera válida la información de que el dominio incaico en Moquegua (y la región al Oeste, cruzando el río Desaguadero) se produjo tras un largo asedio y resistencia de los lugareños al cerco impuesto por las tropas incaicas:

El Inca les envió la gente que pidieron, con sus mujeres e hijos, de los cuales poblaron dos pueblos; el uno al pie de la sierra donde los naturales habían hecho el fuerte; llamáronle Cuchuna que era nombre de la misma sierra; al otrollamaron Moquehua. Dista el uno pueblo del otro cinco leguas; y hoy se llaman aquellas provincias de los nombres destos pueblos, y son de la jurisdicción de Collasuyu. (Ibid.) $)^{13}$

Sin embargo, algo más ha llamado nuestra atención en lo referido sobre el particular por el cronista Garcilaso. En efecto, el cronista mestizo completa la información sobre esta conquista de los incas señalando que los encargados de organizar a la población bajo

13 Según lo indica Rostworowski (1986, p.128), durante el Horizonte Tardío los valles del Colesuyo abrazaban curacazgos de diversas extensiones entre ellos Cochuna cuyos naturales eran conocidos como Capangos hacia 1595-1600. 
el dominio incaico dieron cuenta de que entre su población había quienes administraban veneno para producir sino muerte, grandes estragos físicos entre sus enemigos: "Era un veneno blando, que no morían con él sino los de flaca complición; empero, los que la tenían robusta vivían, pero con gran pena, porque quedaban inhabilitados de los sentidos y de sus miembros y atontados de su juicio y afeados de sus rostros y cuerpos". Ayudados por los propios lugareños, los incas exterminaron al grupo de aquellos envenenadores, destruyeron sus casas, quemaron su ganado y arrasaron sus tierras ordenándose que quedasen desiertas (ibid., p.137). Cierta o no esta información sugiere un procedimiento que habría estado orientado directamente a eliminar a un sector de la población del lugar, a todas luces dirigente y encargado de desarrollar actividades rituales que en el relato de Garcilaso adquieren la forma de prácticas maléficas o de hechicería como se decía en la época colonial para describirlas.

Dejando de lado si fue o no Mayta Cápac quien ordenara dichos traslados, puede entenderse que la referencia al citado inca de alguna manera estaría indicando que la costumbre de tales desplazamientos de población tendría una antigüedad mayor a la existencia misma del predominio incaico. En efecto, si bien antes del dominio incaico podemos encontrar este tipo de desplazamientos poblacionales todo indica que se hacían de manera más bien simple y a nivel de las organizaciones locales, a fin de asegurar de manera permanente el control de determinados espacios ecológicos a distancia. En cambio, en el caso mencionado por Garcilaso y atribuible al dominio incaico se observa que los mitmaqkuna enviados a Moquegua debían cumplir sus funciones a través de dos grupos: uno instalado en la zona alta (serrana) ocupando la fortaleza de Cuchuna que había sido construida como defensa por los propios lugareños - afirma Garcilaso - en tanto que el otro grupo estaba apostado a poca distancia pero en la vertiente occidental de los Andes. ${ }^{14}$

14 Es probable que aquello que en la primera etapa de la expansión incaica pudo haberse realizado a través de un solo grupo de mitmaqkuna, durante la mayor expansión del predominio incaico se hiciera mediante dos agrupaciones, dada 
Según las versiones de cronistas que como Garcilaso y Murúa se interesaron más por estos traslados demográficos, fue política del Tahuantinsuyo dar al poblador mitmaq un habitat de clima y topografía similares al propio. "Y a estos mandaba trasladar y mudarse a otra parte y provinzia que fuese del mismo temple e calidad y dispositivos que la otra donde eran naturales y a estos se llamaba mitmaq" (Murúa, 1946 [1590], p.45; véase también Garcilaso, 1959 [1609], p.226). Creemos que hubo generalización por parte de los cronistas en cuanto a este tópico sobre todo si tomamos en cuentas que los traslados se hicieron en muchos casos por razones de orden táctico y que dentro del periodo estatal los grupos movilizados debieron ser en un primer momento de origen cuzqueño por lo que las mencionadas similitudes climáticas se habrían tomado en cuenta sólo de manera secundaria. En todo caso, tratándose de la finalidad demo-económica y sobre todo de la explotación ecológica, el traslado de mitmaqkuna a lugares de condiciones parecidas a los propios; además de perseguir su mejor adaptación, supone la necesidad evidente del sistema económico andino, de colocar grupos especializados para determinados cultivos. Tratándose de asentamientos permanentes, esta similitud del medio geográfico hacia más viable la tarea de "colonización", entendiendo como tal las actividades de estos grupos de mitmaqkuna dirigidas a ganar para el estado inca recursos ecológicos y humanos. Dicho de otra manera, revertir hacia el control del estado la producción y/o fuerzas de producción de una zona.

\section{A manera de conclusión}

Guardamos para el final las referencias hechas en las crónicas o en testimonios como las visitas respecto a la condición social y al carácter hereditario de la situación de los individuos mitmaqkuna.

la mayor complejidad producto de los lógicos cambios de escala por el aumento de población bajo control de los incas, y el consiguiente incremento de recursos económicos que manejaban. 
Analizando detenidamente los datos que por ejemplo nos brinda la visita a Huánuco encontramos, entre otras, las siguientes referencias: "y cuando alguno o se muere ponen o queda su hijo en su lugar si lo tienen”; “...cuando algunos de los dichos mitimaes se muere que no deja hijos ponen otro en su lugar del mismo pueblo donde era natural el difunto y que esto se hace en cuanto a esto"; "y estos eran para siempre y sus hijos que tenían sucedían en lo mismo aunque fuesen multiplicando muchos y si morían sin dejar bijas ponían otros en su lugar" (Ortiz de Zúñiga, 1967-1972 [1562], p.74).

Los tres testimonios consignados presentan un panorama mucho más complejo que la simple sucesión hereditaria de padre a hijo recogida por el visitador español ¿Hubo en realidad herencia de la condición de mitmaqkuna?, y si así fue ¿bajo qué normas? Bien sabemos que las reglas en la sucesión o el parentesco en el Tahuantinsuyo como en cualquiera otra sociedad arcaica o tradicional se diferencian bastante de las normas de herencia y parentesco en Occidente y sobre todo en la España moderna. Ya señalamos al principio que los mitmaqkuna eran ayllus completos movilizados o trasladados de manera permanente y que si tomamos en cuenta la distinción que hace la lengua quechua entre el extranjero de paso y el que se ha de quedar extendiendo este carácter permanente del individuo al sistema, encontramos explicable una sucesión continua que asegure la permanencia del grupo mitmaqkuna. Entonces, cuando se dice que al morir un individuo su hijo lo sucede, podemos entender que se trata no de un individuo cualquiera sino del jefe del grupo, de aquí que se diga: "y sus hijos que tenían sucedían en lo mismo aunque fuesen multiplicando mucho", puesto que el jefe y el resto de los integrantes del ayllu tienen la función o calidad de mitmaqkuna. Debido a su carácter estable, su situación no puede ser descrita como una mera labor sino como una forma de vida, un status que comprendía al ayllu como totalidad. Prueba de lo cual sería el que se acudiera en muchos casos a las líneas colaterales del parentesco, "poner otro en su lugar, del mismo pueblo donde era natural el difunto” (ibid.).

Por estar directamente vinculados al estado inca y globalmente por la calidad propia de sus funciones, la posición de los mitmaqkuna 
dentro de la fuertemente jerarquizada sociedad incaica, tuvo necesariamente que ser de gran importancia cuando no de privilegio, respecto a los otros miembros del común de los ayllus. Así parecen entenderlo algunos cronistas como Pedro Cieza de León quien afirmó que "tanto por los incas fueron honrados y privilegiados y tenidos después de los orejones" (Cieza, 1967 [1553], p.73). Si contemplamos que en el país de los incas la jerarquía social estaba en relación directa a la pertenencia o vínculos con las élites, el hecho de que se considere a los mitmaqkuna en una posición que seguía a la de los orejones y que además fueran tenidos como "los más nobles de las provincias" indica que los grupos de mitmaqkuna serían reales núcleos politico-religiosos que en cada zona o cuanto menos (lugar estratégico), sea en el orden de lo administrativo o lo económico, actuaban como una suerte de grupo de presión de la élite gobernante inca. Sin embargo, ello no significó que rompieran sus vínculos con las autoridades y tradiciones culturales de sus lugares de origen.

De todas formas, si interpretamos los datos de las crónicas en el sentido de que los nuevos grupos de la élite se integraban en parte con el personal provincial que se aliaba al Cuzco, quedaría explicado el hecho de que aún, sin proceder directamente de dicha ciudad, los mitmaqkuna sean señalados como los más importantes luego de los orejones. Su influencia política, económica y social se deja notar con bastante claridad cuando se les requiere para adherirse al bando de Huáscar en la pugna sucesoria a la muerte de Huayna Cápac:

Creo yo para mí aunque podría ser otra cosa, que Atoco se halló en la prisión de Atahuallpa y, muy sentido porque ha sí se había descabullido, sacando la más gente que pudo de los Cañares, se partió para Quito, enviando por todas partes a esforzar a los gobernadores y mitimaes en la amistad de Guáscar. (Ibid., p.24)

Queda pendiente la respuesta a la cuestión de que si el prestigio y el peso que las crónicas le señalan a los mitmaqkuna tenían o no directa correspondencia con las tareas políticas que el mismo tipo de fuentes les asignan. De ser así, su jerarquía social variaría según sus 
diversas funciones, siendo entonces una posición menor la correspondiente a los grupos de actividad únicamente económica. Esto se relativiza en cuanto hemos afirmado que el asentamiento de mitmaqkuna implicaba un sistema dual de grupos: económico-colonizador (léase domesticación y control de las ecologías) con un sector político o de control militar permanente.

El tema de su importancia y prestigio nos conduce a la consideración de por lo menos algunos símbolos que lo expresen. Así, Cieza y Murúa les señalan privilegios que se ubican por lo general en el orden de lo suntuario, como ser uso de ropa de lana más fina, plumería, adornos de oro y plata, consumo de coca y acceso a vituallas de uso más bien corriente, en este caso en proporción mayor que el común de los individuos (ibid., p.74-77). Tomando en cuenta que el primer grupo de artículos se reservaba para el uso de las élites cuzqueña o local, el acceso a ellos por parte de los mitmaqkuna tendría que entenderse como señal de privilegio cuando no símbolo de jerarquía. Sin embargo, cabe la posibilidad de que los cronistas hayan generalizado una información que bien pudo referirse solo a los "jefes" o curacas mitmaqkuna. En ese caso, tales privilegios expresarían simplemente el derecho de quien, como curaca o malku de unayllu, usufructuaba cosas o recibía prebendas reservadas como regla general para la élite. Una posición prudente nos obliga a sostener, a la espera de datos más certeros sobre el particular, que si algunos de estos llamados privilegios se extendían al resto de individuos del grupo mitmaqkuna tendría que haber sido bajo los términos de la reciprocidad y el reparto de excedentes usuales entonces. Incluyendo lo afirmado por Cieza: "y la paga que se les hacia era en algunos tiempos mandalles dar algunas ropas de lana y plumas o brazaletes de oro y de plata a los que se mostraban más valientes, también les daban mujeres de las muchas que en cada provincia guardaban en nombre del Inca" (ibid., p.76). ${ }^{15}$ Pesa además el hecho de que al referirse a todos estos casos la visión premial, habitual en el Occidente medieval y sobre todo moderno,

15 Sobre todo si como es conocido, también los cronistas señalan este tipo de gratificaciones para los guerreros luego de importantes acciones de conquista. 
de forma muy probable haya tenido que ver en la configuración de tales informaciones. Hay que recordar aquí que diversos autores han especificado que en las relaciones ayllu-estado o individuo-estado, las relaciones de reciprocidad en el llamado Tahuantinsuyo son asimétricas a favor del Inca, esto quiere decir que lo que recibe es económicamente hablando mayor que lo que retribuye, pero estableciéndose si un equilibrio a nivel de lo simbólico (Alberti; Mayer, 1974, p.17). Parece entonces comprensible que lo que el Inca entregaba a los mitmaqkuna estuviese inscrito sobre todo, en el orden de lo suntuario que, como sabemos, estaba dotado de un fuerte contenido simbólico.

De ser valedero lo que afirmáramos en el sentido de que junto con su jefe o curaca todo el grupo cumple la función de mitmaqkuna y que la misma equivale a un modo de vida, una situación que compromete al ayllu. En su totalidad, se hace más comprensible la alta posición que los cronistas les señalan. La jerarquía y los privilegios que las fuentes reconocen para ellos serían así expresiones de reciprocidad asimétrica entre el estado incaico y los curacas de grupos mitmaqkuna extendida a los integrantes de los mismos. Sobre este particular habría que remarcar finalmente, que los mitmaqkuna formarían parte de los sectores "ricos" y poderosos de las poblaciones andinas prehispánicas. Si tomamos como ejemplo las informaciones recogidas en la localidad de Pocona en 1556 y que analizaremos en conjunto con detenimiento más adelante, veremos que Hernando Turumaya uno de los curacas de la zona y al parecer el líder máximo entre los mitmaqkuna, es señalado con preeminencia política, social y económica sobre Juan Xaraxuri su contraparte, siendo fácil observar que el primero ejercía también mayor control sobre grupos humanos y lugares de producción.

De cualquier manera, siempre estamos obligados a andar con mucho tiento a la hora de tomar en cuenta la información documental considerando, en particular, la fecha o época de su producción. Utilicemos como ejemplos lo que se puede recoger en primer lugar de una Probanza llevada a cabo en 1580 por Francisco Sayre Túpac a nombre de los incas del Cuzco cuando un tal Pedro Purqui se presentaba como curaca principal de los "mitimas cañares" residentes 
en Carmenca y en Sacsahuamán y en segundo término en una Información realizada tres años más tarde ocasión en la que se afirma que los citados mitmaqkunacañaris poseían yanaconas para su servicio (Espinoza, 1981, p.358, 364). Como es fácil apreciar, los testimonios corresponden a un momento del desarrollo colonial cuando el proceso general de desestructuración de la organización prehispánica es una realidad incontrovertible por lo que no debería llamar la atención que, dada la procedencia no cuzqueña de la población mencionada en las fuentes citadas, automáticamente se considere mitmaqkuna a grupos movilizados después de la ocupación española de los Andes pero que en la etapa del dominio incaico hubiesen formado parte del sector de la élite que los colonizadores llamaron "incas de privilegio". De cualquier manera, trabajos etnohistóricos especializados en el ámbito del Ecuador prehispánico consideran perfectamente válida la información que da cuenta de mitimaqkuna de origen cañari en el Cuzco.

\section{Referencias bibliograficas}

ALBERTI, G.; MAYER, E. (orgs.). Reciprocidad e intercambio en los Andes. Lima: Instituto de Estudios Peruanos, 1974.

ANDERS, M. B. Historia y etnografía: los mitmaq en Huanuco en las visitas de 1549, 1557 y 1562. Lima: Instituto de Estudios Peruanos, 1990.

CAERO BUSTILLOS, B. C. El extranjero o forastero en el AntiguoTestamento. Yachay, año 21, n.39, Primer Semestre, Universidad Católica Boliviana de Cochabamba, 2004, p.75-97.

CIEZA DE LEON, P. El Señorío de los Incas. Lima: Instituto de Estudios Peruanos, 1967 [1553]. (Estudio Preliminar y notas de Carlos Aranibar.)

CUNOW, H. La organización social del Imperio de los Incas. Lima: spi. 1933 [1896] .

ELLEFSEN, B. La dominación incaica en Cochabamba. Bulletin de l"InstitutFrançais d" Études Andines, Lima, Ifea, v.7, n.1-2, 1978, p.73-86.

ESPINOZA SORIANO, W. El primer informe etnológico sobre Cajamarca año de 1540. Revista Peruana de Cultura, Lima, n.11-12, 1967, p.5-41.

FERNÁNDEZ, D. Historia del Perú. Primera y segunda parte. Madrid: Edición de Juan Pérez de Tudela, 1963 [1571]. 
GARCILASO DE LA VEGA, El Inca. Comentarios reales de los incas. Lima: Editores Asociados Lima, 1959 [1609]. (Edición y estudio preliminar de Aurelio Miro Quesada.)

GONZÁLEZ HOLGUIN, D. Diccionario quechua-español. Lima, 1901 [1608]. Vocabulario de la lengua general de todo el Perú llamada lengua quichua o del inca. Lima, 1952 [1608].

GUAMAN POMA DE AYALA, F. Nueva corónica y buen gobierno. Caracas: Biblioteca Ayacucho, 1980 [1613?]. (Transcripción, prólogo, notas y cronología por Franklin Pease.)

HARRIS, O. Los límites como problema: mapas etnohistóricos de los Andes bolivianos. Bouysse-Cassagne, 1997.

ISBELL, B. J. Parentesco andino y reciprocidad kuyaq: los que nos aman. In: ALBERTI, G.; MAYER, E. (orgs.). Reciprocidad e intercambio en los Andes. Lima: Instituto de Estudios Peruanos, 1974, p.110-148.

ITIER, C. Algunos conceptos quechuas prehispánicos: la raíz yacha-, sus derivados y Pachayachachic, atributo del héroe cultural Viracocha. Religions des Andes et languesindigènes: Equateur-Pérou-Bolivieavant et après la conquêteespagnole. Actes du colloque III d"études andines. Aix-en-Provence: Université de Provence, Centre aixois de recherches latino-américaines. 1993, p.95-113.

LORANDI, A. M.; RODRÍGUEZ, L. Yanas y mitimaes. Alteraciones incaicas en el mapa étnico andino. Los Andes cincuenta años después (1953-2003). Homenaje a John Murra. Lima: Pontificia Universidad Católica del Perú/ Fondo Editorial, 2003, p.129-170.

MAKOWSKI, K.;VEGA CENTENO, M. Estilos regionales en la costa central en el horizonte tardío. Una aproximación desde el valle de Lurín. Bulletin de l"InstitutFrançais d" ÉtudesAndines, Lima, Ifea, v.33(3), 2004, p.681-714.

MURÚA, M. de. Historia del origen y genealogía real de los Incas. Madrid: Edición de Constantino Bayle, 1946 [1590].

MURRA, J. V. Prologo. In: ANDERS, M. B. Historia y etnografía: los mitmaq en Huanuco en las visitas de 1549, 1557 y 1562. Lima: Instituto de Estudios Peruanos, 1990, p.11-17.

ORTIZ DE ZÚÑIGA, I. Visita de la provincia de León de Huánuco en 1562. Huánuco: Universidad Nacional HermilioValdizán/Facultad de Letras y Educación, 1967-1972 [1562]. (Edición a cargo de John Murra.)

RAVI MUMFORD, J. Litigation as Ethnography in Sixteenth-Century Peru: Polo de Ondegardo and the Mitimaes. Hispanic American Historical Review, Duke University Press, n.88-1, 2007, p.5-40. 
REGALADO DE HURTADO, L. En torno a la relación entre mitmaqkuna, poder y tecnología en los Andes. Historia y cultura, Lima, Museo Nacional de Arqueología, Antropología e Historia del Perú, n.17, 1984, p.61-73.

ROSTWOROWSKI, M. La región del Colesuyu. Revista Chungará, Arica (Chile), Universidad de Tarapacá, n.16-17, 1986, out., p.127-135. Historia del Tahuantinsuyu. Instituto de Estudios Peruanos, Concytec, Ministerio de la Presidencia. Lima, 1988.

SANTOTOMÁS, fray D. de. Lexicon o vocabulario de la lengua general del Perú. Lima: Universidad Nacional Mayor de San Marcos, 1951 [1560]. (Edición facsimilar con prólogo de Raúl Porras Barrenechea.)

VILLARÍAS, J. J.; MAMAN, I. de. El encomendero Polo de Ondegardo y los mitimaes de Cochabamba: los interrogatorios contra los indios de Paria y Tapacarí. Anuario de Estudios Americanos, 1998, Sevilla, n.2, tomo LV, p.631-643.

WILLIAMS, V. I. El imperio Inka en la provincia de Catamarca. Intersecciones en Antropología, Buenos Aires: UNCPBA, Facultad de Ciencias Sociales, n.1, 2000, p.55-79. Disponible en: <http://www.scielo.org.ar/pdf/iant/ n1/n1a04.pdf>. Consulta en: 10 ago. 2010. 


\section{ConfluênCIA CULTURAL NAS CRÔNICAS DAS ÍNDIAS}

Ana Raquel Portugal*

Os diversos documentos que tratam do processo de descobrimento, exploração, conquista e colonização do Novo Mundo são conhecidos pela denominação de Crônicas das Índias e existem diversos tipos de texto, entre eles: cartas relatórios, relações geográficas e crônicas (Mignolo, 1982, p.57-116). Geralmente foram produzidas por europeus, especialmente, espanhóis e também por índios e mestiços.

As crônicas dos espanhóis possuem uma dimensão literária e também ideológica e são reflexo do pensamento renascentista, mesclado com traços medievais em que os cronistas tentam assimilar mentalmente a realidade do Novo Mundo (Elliott, 1984). As expedições marítimas, financiadas pelo setor privado em sua grande maioria, foram responsáveis também pela produção de milhares de documentos. Grande parte das crônicas foi gerada como uma obrigação, visto que o capitão da expedição tinha que descrever para o rei suas atividades e como eram as novas terras descobertas.

Havia outros motivos para a preparação desse tipo de documentação. Poderiam ser gerados documentos pela vontade própria de entender e dar a conhecer esse Novo Mundo, bem como com o intuito

\footnotetext{
* Professora de História da América da Unesp (câmpus de Franca).
} 
de mudar a situação pessoal, se defendendo de algum processo judicial ou mostrando seus feitos na esperança de conseguir méritos da coroa. ${ }^{1}$ A honra era algo importante para o espanhol desse período, sendo relacionada à reputação, ou seja, a aparência importava mais do que a realidade. E essa honra faria alcançar a fama, almejada pela maioria que queria imortalizar o próprio nome (Fazio Fernández, 2005, p.134). Para tal, os conquistadores redigiam a "probanza de mérito", um gênero de escrita que tinha por finalidade enaltecer os próprios feitos. Exemplo disso são as obras de Hernán Cortés (15191526) e Bernal Díaz (1552), que legitimam a busca por recompensas (Restall, 2006, p.40-41).

Dentre esses documentos, havia aqueles de ordem etnográfica, produzidos por cronistas que dominavam uma ou várias línguas indígenas, como por exemplo Toríbio Motolínia (1536), Diego de Landa (1566), Bernardino de Sahagún (1577), Juan de Betanzos (1551) e Cristóbal de Molina, el cuzqueño (1552). Esses foram os fundadores da etnografia americana e contribuíram indiretamente para preservar a memória autóctone, visto que a grande motivação era identificar as “idolatrias” para extirpá-las.

Algo sempre presente nas crônicas e que reflete a tentativa de compreensão do outro é o processo de alteridade. ${ }^{2}$ Todorov (1983), pesquisador búlgaro, procura mostrar em sua obra que os espanhóis descobriram, conquistaram e depois procuraram conhecer para poder dominar. Cortés foi um dos que mais buscou informações sobre o povo que ele almejava subjugar política e economicamente. Já Las Casas, segundo o autor, tratou de compreender os povos indígenas para poder assimilá-los culturalmente.

1 Como exemplo, podemos citar Diego de Landa, que sofreu um processo judicial na Espanha, em virtude das arbitrariedades praticadas contra os índios e espanhóis em Yucatán. Para tal, redige a Relación de las cosas de Yucatán (1566).

2 Embora trate do mundo grego, François Hartog (1999), em sua obra O espelho de Heródoto, tece reflexões sobre alteridade e os processos de percepção e enunciação do Outro, tornando-se indispensável na análise do encontro/desencontro de espanhóis e indígenas na América. 
Os cronistas possuíam diversos fins, mas todos descreveram e propagaram dados sobre o Novo Mundo, numa tentativa de integração intelectual desse mundo à mentalidade ocidental. Poucos realmente são os que chegaram a entender o mundo indígena, pois, para tal, era necessário pelo menos conhecer a língua desses povos.

A maioria dos cronistas eram homens de poucas letras, havendo inclusive grandes conquistadores que eram analfabetos, como é o caso de Francisco Pizarro e Diego de Almagro. No entanto, os cronistas liam muito, ou pelo menos aquilo a que tinham acesso na América, e tentavam fazer o melhor que podiam em suas obras. Apesar de terem motivos variados para realizar suas obras, todos tinham consciência que essa atividade requeria retórica (Valcárcel Martínez, 1997, p.429), ou seja, que os livros de história deveriam ser redigidos em linguagem culta, elegante e respeitar a verdade dos fatos. Para alcançar essa verdade faziam uso do "testigo de vista", valiosa contribuição para persuadir e legitimar seu argumento (Hartog, 1999, p.276).

As Crônicas das Índias são um testemunho vivo do encontro/ desencontro da cultura europeia, neste caso, a espanhola, com as culturas indígenas que habitavam o Novo Mundo. Quando nos referimos ao encontro desses mundos diferentes e que mudaram o curso de suas histórias devido a essa aproximação cultural, não podemos deixar de mencionar os resultados desse cruzamento cultural ocorrido no início do século XVI. Para os povos conquistados, a conquista espanhola significou o despojo de seus meios de produção e a impossibilidade de voltar a organizá-los ao seu modo. Significou também a desarticulação das estruturas e, por vezes, a formação de costumes sincréticos.

Os espanhóis ao descreverem o mundo americano tinham uma visão etnocêntrica, com valores e juízos preestabelecidos e, dessa forma, era difícil captar o caráter social das instituições locais. Os povos por eles dominados, por sua vez, passam a integrar-se ao mecanismo da "aculturação", entendido aqui como um processo de adaptações e resistência.

Segundo os historiadores Simon e Cooper, que estudaram áreas conquistadas pelos romanos, o processo vivido pelos grupos 
autóctones foi de continuidade do que havia sido desenvolvido quando da chegada dos romanos a outros povos, com a adoção e a adaptação de seus traços culturais dentro da cultura nativa (Webster; Cooper, 1996, p.83, 86). O mesmo aconteceu em relação aos grupos étnicos americanos, que viveram um processo de interação recíproca com os europeus com continuísmos e rupturas, num contexto de conquista e imposição política e cultural.

Quando examinamos contatos entre culturas diferentes, percebemos que o mais usual é a fusão cultural e o predomínio de uma cultura sobre a outra, depois de um processo sempre complicado em que a recepção de elementos culturais implica seleção de uns, o repúdio a outros e ainda a modificação dos demais. O resultado é uma mescla sempre complexa e às vezes difícil de interpretar. Ocorrem também fenômenos de resistência, que podem ser de cunho seletivo em relação a determinados elementos culturais ou de resistência total (Céspedes del Castillo, 1999, p.10-11). O que podemos perceber é que se faz necessário entender de que modo os grupos étnicos americanos modificaram seus valores e tradições frente aos ocidentais e isso é possível através da análise de algumas crônicas produzidas no período colonial, como, por exemplo, de Cieza de León e Juan de Matienzo, nas quais poderemos perceber, entre outras mudanças, a representação de alterações no significado de estruturas primordiais do mundo indígena. É o caso do ayllu, sistema de parentesco andino, que foi transformado em uma estrutura com conotação territorial após a chegada dos espanhóis.

O cronista Cieza de León é fundamental para a compreensão do ayllu, mesmo sendo um soldado que vivenciou o período inicial da conquista e, como se sabe, eram raros aqueles que dominavam a língua quéchua. Ele, diferentemente de seus companheiros, tinha uma curiosidade aguçada, que o fez tentar transpor esses limites linguísticos.

A obra de Juan de Matienzo (1967 [1567]) é de grande importância para apreendermos o momento histórico em que o ayllu se transforma em um espaço territorial, pois este cronista foi o mentor das reduções toledanas. De cunho jurídico, essa crônica representou o discurso de legitimação do poder espanhol sobre o povo inca. 
Em sua crônica, Cieza de León tratou da genealogia dos incas, sendo que a sociedade incaica era fundada em linhagens, que tinham relação com parentesco. Essa genealogia teve valores políticos e ideológicos, ${ }^{3}$ já que justificou a organização social estabelecida e o poder assumido por determinada camada social ou grupo étnico, tido como superior.

As informações coletadas por Cieza não obedeceram a uma sequência cronológica, pois faziam parte de uma memória coletiva. Pease coloca que "no es posible atribuir a las tradiciones orales las precisiones cronológicas ni las identificaciones personales a que el pensamiento histórico europeo nos ha acostumbrado" (Pease, 1978, p.81).

Nos primeiros capítulos de sua crônica, Cieza de León procurou descrever o período pré-incaico. Segundo ele, houve um dilúvio e depois da tormenta apareceu Viracocha, o "Hacedor de todas las cosas" (Cieza de León, 1991 [1553], p.5), que criou inclusive o Sol.

No capítuloVI, relatou o mito dos irmãos Ayar e prosseguiu mostrando como Manco Capac chegou e fundou Cuzco. Baseado em suas categorias, contou a história dos chefes incas em sequência dinástica e dentro de um sistema monárquico.

savemos que ovo así en lo del govierno como en sojuzgar las tierras y naçiones para que debaxo de una monarquía obedeçiesen a un señor que solo fuese soberano y dino para reynar en el imperio que los Yngas tuvieron. (Ibid., p.23)

Na descrição sobre o casamento do inca com uma irmã, a Coya, ficou explícita a admiração de Cieza diante de tal fato, que em realidade era de grande significado, pois comprovava a importância do ayllu real, que era endogâmico e matrilinear.

3 Ideologia entendida como "o conjunto de ideias acerca do mundo e da sociedade, que correspondem a interesses, aspirações ou ideais de uma classe num contexto social dado, que guia e justifica o comportamento dos homens de acordo com estes interesses, aspirações ou ideias” (Vásquez apud Martins, 1988, p.6). 
Y fue por ellos hordenado que el que oviese de ser rey tomase a su hermana, hija ligítima de su padre y madre, por mujer para que la çuseçión del reyno fuese por esta vía confirmada en la casa real, pareçiéndoles por esta manera que, aunque la tal mujer y ermana del rey de su cuerpo no fuese casta y usando con algúnd onbre, dél quedase preñada, era el hijo que naçiese della y no de muger estraña [...]. (Ibid., p.25)

Os quiposcamayos eram responsáveis pela memorização de todos os feitos de seus soberanos e, assim que um inca morria, começavam a contar suas conquistas e faziam-se cantos para sempre relembrá-lo. Porém, se fosse um inca covarde, tratavam de não recordá-lo.

Os incas eram tão temidos que "de la sonbra que su persona hazía no osavan dezir mal” (ibid., p.34). Porém,

como siempre los Yngas hiziesen buenas obras a los questavan puestos en su señorio sin consentir que fuesen agraviados ni que les llevasen tributos demasiados ni les fuesen hechos otros desafueros, sin lo qual, muchos que tenían províncias estériles y que en ellas sus pasados avían bivido con neçesidad, les davan tal horden que las hazían fértiles y abundantes, proveyéndoles de las cosas que en ellas avía neçesidad; y en otras donde avía falta de ropa por no tener ganados, se los mandava dar con gran liberalidad. (ibid., p.35)

Essa imagem de redistribuição estatal como obra humanitária persuadiu os cronistas espanhóis de que o Estado inca detinha o controle da economia e sociedade com o objetivo de beneficiar todo o povo; como Murra (1975, p.42) conceituou, tratar-se-ia de uma "generosidad institucionalizada".

Cieza prosseguiu sua obra descrevendo a riqueza que essas terras possuíam, pois ouro e prata abundavam. A grandeza dos caminhos incaicos também foi alvo de admiração do cronista. Ele escreveu sobre o gado e as caçadas reais, quando o inca saía com muitos homens para realizar essa tarefa e o produto de tal atividade era repassado para os depósitos estatais. 
As conquistas efetuadas pelos incas seguiam um método, que tinha por princípio a reciprocidade.

[...] embiava presentes a los señores naturales.

$Y$ con esto y con otras buenas maneras que tenía, entraron en muchas tierras sin guerra [...] y si en la tal provinçia no avía mantenimiento, mandava que de otras partes se proveyese [...]. (Cieza de León, 1991 [1553], p.46)

Através de uma passagem da crônica de Cieza de León, constatamos que os ayllus prosseguiram com suas terras e seus costumes durante o período incaico.

Los señorios nunca los tiravan a los naturales. A todos mandavam unos y otros que por Dios adorasen al Sol; sus demás religiones y costumbres no se las proyvían [...]. (Ibid., p.47)

Cieza descreveu como eram feitos os censos através dos quipus, escreveu sobre os tributos, sobre os mitmaqs e de como estes não perdiam as características de seus ayllus, apesar de serem deslocados. Ele percebeu que cada povo se vestia de um modo, o que demonstra que os hábitos de cada ayllu eram respeitados. Cieza de León não se referiu em sua crônica à palavra ayllu, até porque seu desconhecimento da língua quéchua o fez necessitar da ajuda de intérpretes.

Partimos do pressuposto de que essa dificuldade e também o fato de ser um dos primeiros cronistas a tomar contato com a história dos incas fizeram que não utilizasse diretamente o vocábulo ayllu. Porém, ao longo de sua obra, pudemos perceber as diversas características que aparecem em povos organizados em ayllus. O desconhecimento do cronista do vocábulo ayllu não impediu que contribuísse com dados sobre essa estrutura.

Em sua crônica, Cieza de León, não deixou de abordar nenhum dos aspectos organizativos do Tahuantinsuyu. Ele discorreu sobre o sistema decimal, sobre a formação dos exércitos, a questão da língua oficial ser o quéchua, sobre os sacrifícios, as festas, os nobres, 
os casamentos por interesse de reciprocidade, enfim, sua obra é das mais completas que se pode consultar para obter informações sobre os incas.

Quando Cieza de León quer referir-se a outras etnias, usa o termo "linhagem": "estava un varrio çerca de la çibdad donde bivían un lináje de jente a quien llamavan Alcaviquiça [...]” (Ibid., p.100).

Nesse período, entre os cronistas, era comum referirem-se a povos ligados por laços de parentesco com o termo linhagem. Podemos dizer que Cieza entendeu, desse modo, o ayllu como uma linhagem, que tinha suas terras, seus costumes e crenças. Mais da metade da crônica foi consagrada à descrição das conquistas e, poucas, derrotas dos incas. Os últimos capítulos foram dedicados aos confrontos entre Huascar e Atahualpa e, seguindo a tradição espanhola, Cieza mostrou-se favorável a Huascar, por ser este filho "legítimo" e herdeiro da mascapaicha (uma espécie de coroa real). Ao longo da crônica, percebemos como os vínculos de parentesco, as solidariedades étnicas e os princípios de reciprocidade e redistribuição foram utilizados ideologicamente para favorecer e justificar novas relações sociais.

Cieza de León pode não ter tratado o conceito de ayllu diretamente, mas fornece as principais características de tal estrutura. Linhagem, genealogia foram conotações que no século XVI estiveram ligadas ao conceito de ayllu. Mesmo que não significassem a acepção correta dessa estrutura, pelo menos correspondiam ao que a maioria dos cronistas concebia por ayllu. Tinha relação com a ideia de família, assim como a teve outra palavra quéchua, panaca, que segundo os cronistas eram os descendentes dos incas. Cieza de León também referiu-se a esses ayllus reais, apresentando-os como grupos ordenados dinasticamente, segundo sua ideia de genealogia.

Cieza de León percebeu o ayllu enquanto linhagem e genealogia e descreveu os hábitos inerentes a agrupamentos indígenas organizados em ayllus, porém não indicou o vocábulo ayllu, visivelmente devido à deficiência no recolhimento das informações. Não conceituar o ayllu, por sua vez, teve sentido, pois a preocupação da época era saber quais eram os chefes e os povoados existentes e não que 
tipo de laços os ligava. Os povos organizados em ayllus não tinham significado como grupo de parentesco para os encomendeiros, e sim como força de trabalho.

Mais tarde, com Juan de Mantienzo (1967 [1567]) passou-se a procurar informações sobre pueblos, caciques e índios, pois esse tinha a intenção de reagrupá-los para que produzissem mais e fossem doutrinados. Matienzo foi um jurista espanhol que escreveu sua crônica na sétima década do século XVI, depois de ter ocupado o cargo de ouvidor na Chancelaria da cidade de La Plata. Homem de grandes conhecimentos e experiência, dominava a legislação castelhana e tornou-se um observador perspicaz. Sua obra é um acúmulo de julgamentos pessoais.

Juan de Matienzo iniciou sua crônica acusando os incas de serem tiranos, começando pelo inca Manco Capac que, segundo ele, "hizo leyes a su gusto y provecho, y no al de sus súbditos" (ibid., p.6). Deu como provas de tirania a crueldade dos incas que exploraram o povo e lhes retiravam até as mulheres. Sacrificavam animais e crianças e retiravam gente de um local para passá-la a outro, os mitmaq. Com isso, quis legitimar a conquista espanhola, pois se os incas eram tiranos, Pizarro veio libertá-los por um desígnio divino.

Matienzo (ibid., p.16) considerou os índios "pusilánimes y tímidos" sem responsabilidades, nem honra e, por isso, teriam nascido para servir e não para pensar. Para que não ficassem na ociosidade, recomendou algumas leis que permitiam a contratação de índios mediante o pagamento de salário. Desse modo, também começou a preocupação de Matienzo em propôr o reagrupamento de índios que viviam nas parcialidades, compostas de ayllus.

Segundo María Rostworowski, alguns cronistas do século XVI usaram o termo parcialidade referindo-se aos ayllus, sendo que a palavra "parcialidad corresponde a una mitad socio-política de un curacazgo o de un señorio, que a su vez compreendía a varios ayllus" (Rostworowski, 1981, p.38). Matienzo utilizou essa concepção:

En cada repartimiento o provincia hay dos parcialidades: una que se dice de hanansaya, y otra de hurinsaya. Cada parcialidad tiene un cacique 
principal que manda a los prencipales e indios de su parcialidad, y no se entremete a mandar a los de la outra. (Matienzo, 1967 [1567], p.20)

O equivalente em quéchua para o vocábulo parcialidad era suyu.

\section{Suyu. Parcialidad.}

Hanan suyu. El de arriba.

Hurin suyu. El de abaxo. (Holguin, 1608, p.333)

No entanto, o próprio Diego Gonzalez Holguín incorreu numa interpretação errônea da palavra ayllu, pois a tornou equivalente a parcialidade, genealogia, linhagem de uma nação (1608, p.39), demonstrando a confusão que os espanhóis fizeram entre as palavras ayllu e parcialidade.

Juan de Matienzo usou o termo parcialidade ao referir-se ao conjunto de ayllus existentes em uma determinada região. Porém, ao longo da primeira parte de sua crônica, na qual tratou de como viviam os índios, sempre usou o termo ayllu no sentido de aldeia ou povoado, sem descrever como se organizava a população. O importante para ele foi a existência de parcialidades com diversos ayllus, os quais tinham seus chefes locais a quem o povo pagava tributo.

Estos caciques y principales no entienden en otra cosa más de lo que está dicho, porque ni ellos labran heredades, ni se alquilan para trabaxar, antes se mantienen del tributo que les dan los indios de su ayllo. (Matienzo, 1967 [1567], p.21)

Argumentando que os índios eram explorados por seus chefes e que estes também deviam trabalhar, engendrou a ideia das reduções, pois agrupar diversos ayllus debaixo da tutela de um administrador espanhol faria que os índios trabalhassem, inclusive seus curacas, em prol da coroa espanhola.

que los indios se reduzgan a pueblos; que se hagan alcaldes y regidores y alquaciles y otros oficiales de Consexo, para que hagan justicia en pleitos civiles [...]. (Ibid., p.48) 
Matienzo propôs diversas leis que defendiam os índios de seus curacas e também dos encomendeiros, pois, como funcionário da coroa que era colocava os interesses do rei espanhol acima de tudo. Os índios deveriam ser pagos diretamente, não poderiam receber por intermédio dos curacas, já que poderiam ser enganados por eles. Os encomendeiros tinham que cuidar dos índios, sem lhes fazer nenhuma injúria, senão seriam punidos. Os índios que não estavam encomendados foram reduzidos.

Na primeira parte de Gobierno del Perú, Matienzo mostrou que os incas eram tiranos e, por isso, não tinham direito àquelas terras. Os espanhóis que vieram salvar os índios do jugo inca tiveram legitimada sua conquista. Também descreveu alguns traços da organização política, econômica e social derivados do período incaico e que permaneceram durante a época colonial. Mas sua grande preocupação de jurista foi elaborar leis que visavam a "proteção" dos índios contra seus senhores, curacas ou encomendeiros, e também leis que tirassem tais índios da ociosidade e os fizessem trabalhar e pagar tributo à administração espanhola.

Na segunda parte da crônica, descreveu a administração colonial, propondo leis que indicariam as funções de todos os oficiais que trabalhassem para a coroa.

Enquanto Cieza de León (1553) entendeu os ayllus como linhagens, genealogias, ou seja, de certo modo mais próximo à ideia de parentesco, Juan de Matienzo (1567) os descreveu como partes integrantes das parcialidades, dando-lhes uma conotação de territorialidade.

Essas interpretações, apesar de não estarem de todo erradas, não dão o significado mais amplo do que foi um ayllu, gerando dúvidas que até hoje permanecem. A ideia proposta por Matienzo de reagrupar os povos indígenas foi aproveitada nas reduções do vice-rei Toledo. Desse modo, com o ayllu inserido num novo âmbito, seu conceito foi confundido com redução ou comunidade devido à expressão de territorialidade que estas estruturas representaram.

Como pudemos perceber, as crônicas são textos resultantes do processo de alteridade vivido entre culturas distintas e representam as 
práticas culturais do século XVI em que grupos étnicos locais foram forçados a alterar seu modo de vida diante do novo, o que não significa que se submeteram aos espanhóis. Quando mencionamos que os cronistas indígenas possuíam um discurso "aculturado", temos em mente a representação discursiva de seu mundo de acordo com suas necessidades de sobrevivência (Stern, 1987). Prova disso são as crônicas de Titu Cusi (1570), Garcilaso de la Vega (1609) e Guaman Poma de Ayala (1615) que, no caso andino, alertam para os danos causados pelos conquistadores espanhóis manipulando o discurso de modo a alcançar seus interesses, que podiam ser pessoais ou coletivos.

Conforme Gruzinski demonstrou, as mudanças culturais ocorridas nesse período propiciaram possibilidades de reorganização dos grupos indígenas diante da desestruturação cultural provocada pelo sistema colonial (Gruzinski, 1986, p.415).

Percebemos então, que no caso de algumas etnias dominadas pelos espanhóis, não houve a passagem da cultura indígena à cultura ocidental, e sim o processo inverso, em que a cultura indígena integrou os elementos europeus. Os grupos que estavam acostumados a produzir excedente econômico e a pagar tributo foram administrados pelos espanhóis de modo a aproveitar o sistema preexistente para controlar a mão de obra. Para isso, contavam com a ajuda de chefes locais que mantinham, como antes, a ligação entre senhores e súditos. Foi essa administração indireta que favoreceu a manutenção das tradições indígenas, apesar da ação espanhola em sentido contrário através da evangelização e das reduções (Wachtel, 1976, p.114-115), que, em verdade, desde o momento inicial da conquista, eram instrumentos para justificar suas pretensões políticas (Pietschmann, 1992, p.16).

Os documentos indígenas são resultantes dessa mescla, em que por um lado há a influência dessa "aculturação", pois os cronistas retratam sua cultura com visão ocidentalizada, mas, por outro, há uma apologia ao seu próprio mundo.

Tais relatos originam-se da confluência de discursos representativos de culturas distintas. A utensilagem mental ${ }^{4}$ do espanhol só

4 Utensilagem mental (Febvre, 1988). 
lhe permitia reproduzir aquilo que via de acordo com seus próprios traços culturais. $\mathrm{O}$ indígena que passou pelo processo de ocidentalização ${ }^{5}$ não apagou de sua memória a própria cultura, apenas começou a filtrá-la sob influência dos modelos europeus. Ao analisarmos documentos do século XVI e XVII, que tratam a história das etnias americanas sob controle dos espanhóis, estamos lidando com um conjunto de informações que são a representação desse mundo indígena, aos olhos de europeus e de mestiços e autóctones influenciados por traços culturais espanhóis. Representação essa entendida como registro de três realidades:

as representações coletivas que incorporam nos indivíduos as divisões do mundo social e organizam os esquemas de percepção a partir dos quais eles classificam, julgam e agem; [...] as formas de exibição e de estilização da identidade que pretendem ver reconhecida; [...] a delegação a representantes [...] da coerência e da estabilidade da identidade assim afirmada. (Chartier, 2002, p.11)

Os textos resultantes dessa confluência cultural representam uma nova realidade, que acabará por ser assimilada e sociabilizada. Para Yukitaba Inoue Okubo, os conjuntos de obras classificados como "indígena”, "espanhol” ou "mestiço" não existiram separadamente, pois houve influência e inter-relação entre as obras ou entre os cronistas (Okubo, 2007, p.79). Isso corrobora a ideia de confluência cultural desses escritos.

As Crônicas das Índias resultam dessas práticas culturais vividas no período colonial, que expressam distintos processos adaptativos e até de resistência. As crônicas fornecem-nos representações da história do descobrimento e conquista da América, bem como de todo o período de colonização. Refletem discursos distintos de grupos que se encontraram numa fronteira intercultural, ${ }^{6}$ permitindo sua

5 Para ocidentalização, ver Gruzinski (2001).

6 Sobre interculturalidade, ver Fornet-Betancourt (2001, p.47); Levin Rojo; Navarrete (2007). 
transposição, mas em que estes dificilmente perdem suas próprias características. Os processos de alteridade e de ocidentalização, bem como as representações do mundo indígena se originam nessas fronteiras discursivas, ${ }^{7}$ nas quais o discurso espanhol e autóctone se encontra ou diverge, mostrando as imagens desses dois mundos em contato.

\section{Fontes}

BETANZOS, J. de. Suma y narración de los incas. In: Crónicas peruanas de interés indigena. Madrid: BAE, 1968 [1551].

CIEZA DE LEÓN, P. de. Crónica del Perú. Lima: Pontificia Universidad Católica del Perú, 1991 [1553]. 4v.

CORTÉS, H. Quinta Carta de Relación. Madrid: Dastin, 2003 [1519-1526].

CRISTÓBAL DE MOLINA, El cuzqueño. Fábulas y ritos de los incas. Buenos Aires: Editorial Futuro, 1959 [1552].

DÍAZ DEL CASTILLO, B. Historia verdadera de la conquista de Nueva España. Madrid: Castalia, 1999 [1556].

GARCILASO DE LAVEGA, inca. Comentarios reales de los incas. Lima: FCE, 1991 [1609]. $2 t$.

GUAMAN POMA DE AYALA, F. Nueva coronica y buen gobierno. Lima: FCE, 1993 [1615]. 3t.

LANDA, D. de. Relación de las cosas de Yucatán. México: Porrúa, 1966 [1566].

MATIENZO, J. de. Gobierno del Perú. Paris/Lima: Ifea, 1967 [1567]. (Travaux de L'Institut Français D'Études Andines, Tome XI. Edition et Etude préliminaire par Guillermo Lohmann Villena.)

MOTOLINIA, T. Historia de los indios de Nueva España. Barcelona: Juan Gili, 1914 [1536].

SAHAGÚN, B. de. Historia general de las cosas de Nueva España. México: Porrúa, 1985 [1577].

TITU CUSI YUPANQUI, inca. Instrucción al licenciado don Lope García de Castro. Lima: PUCP, 1992 [1570].

7 Para o conceito de fronteiras discursivas, ver Portugal (2009). 


\section{Referências bibliográficas}

CÉSPEDES DEL CASTILlO, G. Las fronteras de Europa en la Edad Moderna. In: Ensayos sobre los reinos castellanos de Indias. Madrid: RAH, 1999.

CHARTIER, R. À beira da falésia. Porto Alegre: UFRGS, 2002.

COOPER, N. F. Searching for the Blank Generation: Consumer Choice in Roman and Post-Roman Britain. In:WEBSTER, J.; COOPER, N. Roman Imperialism: Post-Colonial Perspectives. University of Leicester: Leicester, 1996.

ELLIOTT, J. H. El viejo mundo y el nuevo. Madrid: Alianza Editorial, 1984.

FAZIO FERNÁNDEZ, M. El honor español en las crónicas americanas de los siglos XVI y XVII. In: REGALADO DE HURTADO, L.; SOMEDA, H. (Eds.). Construyendo historias. Aportes para la historia hispanoamericana a partir de las crónicas. Lima: PUCP, 2005.

FEBVRE, L. Le problème de l'incroyance au 16e siècle; la religion de Rabelais. Paris: Albin Michel, 1988.

FORNET-BETANCOURT, R. Transformación intercultural de la Filosofía. Bilbao: Desclée, 2001.

GRUZINSKI, S. La red agujerada - identidades étnicas y occidentalizacion en el Mexico colonial (siglos XVI-XIX). America Indigena, Mexico, ano XLVI, n.3, jul-set, v.XLVI, 1986.

O pensamento mestiço. São Paulo: Companhia das Letras, 2001.

HARTOG, F. O espelho de Heródoto. Ensaio sobre a representação do outro. Belo Horizonte: UFMG, 1999.

LEVIN ROJO, D.; NAVARRETE, F. (Orgs.). Indios, mestizos y españoles. Interculturalidad e historiografia en la Nueva España. México: Unam, 2007.

MIGNOLO, W. Cartas, crónicas y relaciones del descubirmiento y la conquista. In: MADRIGAL, L. Í. (Coord.). Historia de la literatura hispanoamericana. Madrid: Cátedra, 1982.

OKUBO, Y. I. Crónicas indígenas: una reconsideración sobre la historiografia novohispana temprana. In: LEVIN ROJO, D.; NAVARRETE, F. (Orgs.). Indios, mestizos y españoles. Interculturalidad e historiografia en la Nueva España. México: Unam, 2007.

PIETSCHMANN, H. La Conquista de América: un bosquejo histórico. In: KOHUT, K. (ed.). De conquistadores y conquistados; realidad, justificación, representación. Frankfurt: Vervuert, 1992. 
PORTUGAL, A. R. O ayllu andino nas crônicas quinhentistas. São Paulo: Cultura Acadêmica, 2009.

RESTALL, M. Sete mitos da conquista espanhola. Rio de Janeiro: Civilização Brasileira, 2006.

SIMON, C. Acculturation and Continuity: Re-assessing the Significance of Romanization in the hinterlands of Gloucester and Cirencester. In:WEBSTER, J.; COOPER, N. Roman Imperialism: Post-colonial Perspectives. Leicester: University of Leicester, 1996.

STERN, S. Resistance, rebellion and consciounes in the Andean Peasant Word, 18th to 20th Centuries. Wisconsin: The University of Wisconsin Press, 1987.

TODOROV, T. A conquista da América. A questão do outro. São Paulo: Martins Fontes, 1983.

VALCÁRCEL MARTÍNEZ, S. Las crónicas de Indias como expresión y configuración de la mentalidad renacentista. Granada: Diputación Provincial de Granada, 1997.

WACHTEL, N. A aculturação. In: LE GOFF, J.; NORA, P. História: novos problemas. Rio de Janeiro: Francisco Alves, 1976. 


\title{
ENSINO DE HISTÓRIA INDÍGENA: TRABALHANDO COM NARRATIVAS COLONIAIS E REPRESENTAÇÕES SOCIAIS
}

\author{
Susane Rodrigues de Oliveira*
}

\section{Introdução}

A partir das experiências de pesquisa e ensino desenvolvidas no âmbito do projeto América indígena: cultura histórica e ensino de História, ${ }^{1}$ apresentamos neste capítulo algumas reflexões e propostas para a abordagem de narrativas coloniais no ensino de História indígena na educação básica. Esse projeto teve por objetivo o estudo das formas de produção e difusão do conhecimento histórico sobre as sociedades indígenas da América nas narrativas coloniais (crônicas, relatos de viagem, cartas e tratados), na historiografia contemporânea, nos livros didáticos escolares e nos discursos de professores e estudantes das escolas de Brasília nos últimos anos. Com base nesses

* Professora do Departamento de História da Universidade de Brasília (UnB).

1 Este Projeto, realizado entre os anos de 2009 e 2012, resultou também na produção de um repositório digital de fontes históricas e materiais didáticos para o ensino de História indígena que se encontra disponível no site <www.americaindigena.com.br>. No ano de 2011, esse projeto se desdobrou numa atividade de extensão intitulada "América indígena: oficinas, pesquisas e materiais didáticos para o ensino de História”, que contou com a participação de estudantes dos cursos de graduação em História e Letras (tradução espanhol) da Universidade de Brasília. No $2^{\circ}$. semestre de 2009 , essa pesquisa contou com o apoio financeiro da Finatec, através do edital 04/2009. 
estudos produzimos ainda uma série de roteiros pedagógicos e fichas temáticas ${ }^{2}$ para o uso dessas narrativas nas aulas de História. Na primeira parte deste texto tecemos algumas considerações teórico-metodológicas sobre o ensino de História indígena, as narrativas coloniais e a produção/difusão de representações sociais; já na segunda, expomos um roteiro pedagógico para a abordagem de um extrato de narrativa colonial em sala de aula.

Esse roteiro pretende não só contribuir com a implementação da lei n.11.645/08 - que institui a obrigatoriedade do ensino de História e Cultura afro-brasileira e indígena nas escolas brasileiras -, mas também estimular, em sala de aula, o estudo dos processos de produção de conhecimento histórico sobre os indígenas, ou seja, a reflexão crítica e a pesquisa sobre as representações elaboradas sobre os indígenas, visando à compreensão da historicidade de suas elaborações e o rompimento com a universalização e naturalização das imagens dos índios na história. Trata-se de um roteiro que tem como referência as propostas pedagógicas de formação escolar para a cidadania e o reconhecimento/valorização das identidades e culturas dos povos indígenas, em sintonia com os Parâmetros Curriculares Nacionais (PCN's) (Brasil, 1998) e as diretrizes curriculares para a educação das relações étnico-raciais (Brasil, 2004). Tais propostas encontram apoio também nas pesquisas desenvolvidas na área de ensino de História por Siman (2005), Bergamaschi (2011), Zamboni(1998), Bonin(2006), Schmidt e Cainelli (2004), Bittencourt (2008), Fonseca (2003), Abud, Silva e Alves (2010).

\section{Considerações teórico-metodológicas}

A história tradicional, de cunho positivista, tomou as narrativas produzidas pelos europeus nos séculos XVI e XVII - sobre os

2 As fichas temáticas são recursos didáticos que apresentam trechos de fontes históricas coloniais referentes às sociedades indígenas da América, bem como propostas pedagógicas para o trabalho de leitura, análise e discussão destas fontes em sala de aula. 
indígenas e as práticas de conquista/colonização da América - como fontes históricas fidedignas e inquestionáveis. De modo geral, as fontes históricas eram tratadas, nessa perspectiva historiográfica, como retratos fiéis do passado e portadoras de verdades absolutas sobre os acontecimentos.

Apesar dos avanços das novas tendências historiográficas que, ao longo do século XX, passaram a questionar a objetividade do conhecimento histórico e o status de verdade das fontes, observamos que, nas últimas décadas, o ensino ministrado nas instituições escolares esteve alheio tanto às transformações operadas no status das fontes e do próprio conhecimento histórico, como às novas perspectivas introduzidas no campo da História indígena. Essas mudanças podem trazer contribuições no sentido de promover, por meio da educação escolar, o questionamento e a desnaturalização de discursos históricos carregados de representações estereotipadas e negativas a respeito do passado indígena na América.

No entendimento das narrativas coloniais e das representações dos indígenas nos apoiamos nos estudos pós-coloniais ${ }^{3}$ e num conjunto de concepções interdisciplinares provenientes da análise do discurso (Foucault, 1986; Orlandi, 2003) e da teoria das representações sociais (Jodelet, 2001; Arruda, 1998). As imagens negativas, generalizadas e naturalizadas difundidas sobre os povos indígenas na historiografia tradicional, construídas sob um ponto de vista colonialista e eurocêntrico, ainda marcam as subjetividades e as práticas de exclusão e inferiorização dos indígenas no presente. Diante disso é que lançamos um olhar pós-colonialista sob as narrativas coloniais, a historiografia e o ensino de História. Como assinala Angela Prysthon (2001, p.34),

3 As inovações pós-colonialistas apontam para o fim de uma "história isolacionista", que percebe o mundo a partir da Europa ou do olhar europeu, buscando uma perspectiva interacionista da história, mais preocupada em compreender como as diversas culturas têm se relacionado no decorrer do tempo (Oliveira, 2012). 
A teoria pós-colonial é uma empresa de descolonização, mas não a descolonização concreta (algo que já foi mais ou menos realizado) das lutas armadas e acordos militares, mas a descolonização da história e da teoria, uma abordagem de fato alternativa do Ocidente. [...] os estudos pós-coloniais reinserem o debate da identidade nacional, da representação, da etnicidade, da diferença e da subalternidade no centro da história cultural mundial contemporânea.

Os estudos pós-coloniais se interessam pelos efeitos da colonização sobre as culturas e sociedades colonizadas, trazendo à baila o protagonismo e as vozes de diferentes grupos sociais, cujas memórias e experiências históricas foram marginalizadas ou desclassificadas nos relatos históricos oficiais. Deste modo, o pós-colonialismo busca

reformular e reorganizar as formas de pensamento instituídas pela dominação colonial e visa superar a dependência em relação ao conhecimento eurocêntrico. [...] O vocábulo pós-colonialismo sugere, numa perspectiva temporal, o período que vem depois do colonialismo. Supõe-se, a partir dessa concepção, que o colonialismo teve um fim enquanto relação de dominação. Sabe-se, porém, que o fim do colonialismo não representou o fim das relações de poder discriminatórias desenvolvidas no seio das sociedades pós-coloniais. (Pereira, 2010, p.6, 9)

É nesta perspectiva que atentamos para as relações de poder constitutivas da produção de saberes que circulam nas narrativas coloniais e no ensino de História e para a importância da linguagem e das representações sociais culturalmente constituídas sobre os indígenas na história, a fim de promover uma "desconstrução das sínteses, das unidades e das identidades ditas naturais, ao contrário da busca de totalização das multiplicidades” (Rago, 1998, p.6).

As narrativas históricas e literárias sobre o Brasil têm início no século XVI, com a chegada dos portugueses e o surgimento das primeiras descrições da natureza e dos costumes indígenas. Elas se revelam nas crônicas, cartas de viagem, diários de navegação e tratados 
descritivos que dão a conhecer as plantas, os animais, o clima, a terra e as sociedades indígenas, constituindo guias de objetos e sentidos encontrados na América. Viajantes, exploradores e missionários do período colonial forneceram, por meio delas, as primeiras imagens das sociedades indígenas, criando um imaginário que em muitos aspectos perdura até nossos dias, tecendo os contornos identitários da nação brasileira e corroborando práticas sociais de exclusão e marginalização dos indígenas. O imaginário histórico presente nessas narrativas se inscreve nos discursos das "descobertas" que, por sua vez, são os discursos que "dão a conhecer o Novo Mundo" (Orlandi, 1990, p.15). Esses discursos, cujos efeitos de sentido até hoje marcam os indígenas com o selo de povos colonizados, são os mesmos quelhes negam historicidade e lhes apontam como seres a-históricos.

A literatura de viagem e as crônicas produzidas no período colonial respondem em boa parte pela construção e proliferação de uma imagem dos indígenas carregada de detalhes exóticos, contornos selvagens e demoníacos. Como "discursos fundadores"4 que davam a conhecer o "Novo Mundo", puderam mobilizar forças no processo de assujeitamento dos indígenas, ao responder "pela instauração de hierarquias, lugares sociais, desigualdades e diferenças entre índios e europeus" (Oliveira, 2002, p.24).

Neste processo de significação revela-se uma repugnância em pensar as diferenças confrontadas pelos europeus na América, uma vontade discursiva de ordenar o universo indígena em espaços simbólicos já conhecidos, de estabelecer um regime de verdade sobre o Outro, ao nomeá-lo como bárbaro, demoníaco, selvagem, tirano, índio, já que não é cristão, branco e nem "civilizado". Com o objetivo de familiarizar os leitores europeus com os eventos e povos ali

4 De acordo com Eni Orlandi (2003, p.13), o que caracteriza um "discurso fundador [...] é fato de que ele cria uma nova tradição, ele ressignifica o que veio antes e institui aí uma memória outra. É um momento de significação importante, diferenciado. O sentido anterior é desautorizado. Instala-se outra 'tradição’ de sentidos que produz os outros sentidos nesse lugar. Instala-se uma nova 'filiação'. Esse dizer irrompe no processo significativo de tal modo que pelo seu próprio surgir produz sua 'memória'”. 
descritos, essas narrativas "ancoraram" as representações dos indígenas naquelas já reconhecidas pela cristandade europeia, tornando o "novo" mais facilmente assimilado, encontrando referências e "aceitação" em concepções já formadas e consolidadas. Como bem disse Angela Arruda (2002, p.17), "a representação aplaca instantaneamente o conteúdo perturbador do outro, retrabalhando-o, tornando-se, assim, a diferença incorporada, dando forma ao holograma”. Numa linguagem significativamente investida de conotação colonizadora, boa parte dessas narrativas descrevem a multiplicidade de etnias indígenas como um grupo homogêneo, sem especificidades históricas e culturais. Como bem atenta Neves (1978, p.31-32),

Quando se fala de "índios", o plural é relativo a uma coleção de indivíduos que podem entre si nomear-se de maneira distinta mas que, para o português, é, no essencial, uma mesma realidade e única realidade. [...] uma coleção de indivíduos sem nomes, mais ou menos próximos e/ou perigosos. Há, então, um movimento duplo em direção à homogeneização: apagam-se as diferenças culturais tribais e as diferenças interindividuais.

$\mathrm{Na}$ tentativa de colonizar e subjugar os habitantes da América, essa homogeneização, expressa na palavra "índio", visava ao apagamento das diferenças étnico/culturais e interindividuais, controlando assim os poderes e perigos de uma diversidade aleatória que parecia tornar impraticável a universalização dos critérios jurídicos e morais em vigor na Europa cristã, e impedia que se aplicassem à América as regras de governo e convivência em uso entre os cristãos (Dias, 1973, p.218-219).

As narrativas coloniais operaram neste processo de homogeneização das diferenças confrontadas pelos europeus na América. As práticas sagradas dos incas foram descritas pelos cronistas espanhóis como formas de idolatria, feitiçaria ou bruxaria, já que vistas como não cristãs e, portanto, concebidas como femininas, bárbaras, demoníacas, profanas, pecaminosas, perversas e doentias (Oliveira, 2012). Na maior parte das crônicas, as huacas (seres/objetos/lugares sagrados) 
dos povos andinos foram representadas como demônios, em oposição ao deus cristão. Já os conceitos de gênero presentes no Peru incaico foram apreendidos sob o mesmo prisma que apagava e silenciava a sua pluralidade. As mulheres incas, quando não excluídas e silenciadas nos discursos dos cronistas, aparecem aprisionadas à representação de mães e esposas submissas, estigmatizadas também como bruxas e feiticeiras, como seres mais diabólicos e vulneráveis ao pecado e às idolatrias. Não por acaso, a maior parte dos cronistas, formados em uma tradição androcêntrica, silenciou a participação ativa e privilegiada das mulheres na sociedade incaica, já que para eles somente os homens deviam tomar conta do governo e exercer os papéis mais importantes. As representações de gênero, presentes no imaginário dos cronistas, redesenharam as mulheres indígenas segundo os modelos hierárquicos da oposição masculino/feminino. Não por acaso, boa parte da historiografia contemporânea tendeu a reproduzir o olhar eurocêntrico e androcêntrico dos cronistas na apreensão do universo indígena, repetindo e revigorando as mediações interpretativas dos cronistas a respeito do feminino (Navarro-Swain, 2006).

A utilização indiscriminada das narrativas coloniais acabou por contribuir na proliferação do olhar eurocêntrico dos cronistas que estiveram a cargo da exaltação dos feitos europeus na conquista, evangelização e exploração colonial da América. Além disso, reforçou uma história baseada no silêncio, na inferiorização e/ou negação dos conhecimentos e práticas indígenas; uma história que acabou negando-lhes o direito de ter especificidades e particulares históricas e culturais reiterando uma série de conceitos globalizantes e essencialistas a respeito de suas identidades e diferenças.

As narrativas coloniais ainda constituem as principais fontes de pesquisa utilizadas pelos historiadores no estudo da América antiga e colonial, dada a escassez de fontes escritas indígenas (Natalino, 2004). ${ }^{5}$ Franklin Pease (1994, p.122) criticou a utilização indiscriminada das crônicas como fontes de pesquisa, mas destacou a

5 Como bem observou Natalino (2004, p.177), isto pode estar relacionado ao "papel preponderante que era desempenhado pelas narrativas orais e por formas 
importância de sua utilização para a compreensão das categorias que proporcionaram a apreensão das antigas sociedades andinas. Além disso, os pesquisadores reconheceram que apesar das crônicas serem escritas sob o ponto de vista europeu, apresentam alguns indícios para a percepção da materialidade indígena (Neto, 1997, p.327). ${ }^{6}$

Apesar de reconhecermos os limites das narrativas coloniais na abordagem das sociedades indígenas, não descartamos a possibilidade de utilizá-las como fontes de pesquisa, considerando a sua dimensão de documentos construídos e não reflexos do real. Enquanto discursos, tais narrativas constituem lugares de significação, de confronto de sentidos, de estabelecimento de identidades e de argumentação. Nesta perspectiva, importa ao pesquisador "sair do já nomeado, do interpretado e procurar entender esses textos como discursos que produziram e produzem efeitos de sentidos a serem compreendidos nas condições em que apareceram e nas de hoje" (Orlandi, 1990, p.18). É nessa perspectiva que propomos uma abordagem das narrativas coloniais como materiais didáticos nas aulas de História, com o objetivo de problematizar as representações construídas sobre os indígenas e discutir as suas condições de produção no cenário da conquista e colonização europeia da América.

Os livros didáticos de História, utilizados nas escolas do Distrito Federal nas últimas décadas, revelam a presença de fragmentos de narrativas coloniais, especialmente de crônicas dos séculos XVI e XVII, entre os textos complementares e fontes históricas. O livro didático História das cavernas ao Terceiro Milênio (Braick; Mota,

de registro muito distintas das que tradicionalmente reconhecemos como tais, como por exemplo os ceques, [...] os quipus, os pallares ou os tocapus".

6 Do ponto de vista simbólico é possível, portanto, investigar qual a dinâmica dos "pontos notados", no outro, a partir de "pontos anotados", pelo cronista, ou seja: através da identificação dos processos de reação, de identidade ou diferença, deflagrados pelos elementos simbólicos do outro em um discurso cuja lógica simbólica seja conhecida. Como afirma Pease, "a crônica [...] deve ser entendida como uma fonte oral, alterada pelo cronista que a estabilizou, escrevendo-a", mas é necessário, para torná-la útil para o entendimento do outro, "situar o cronista" não apenas quanto ao seu itinerário e contexto no qual colheu informações, mas também em sua dimensão histórica mais ampla (Neto, 1997, p.327). 
2002), ${ }^{7}$ produzido para o ensino médio, apresenta dois fragmentos de crônicas escritas sobre os incas. Trata-se de narrativas produzidas pelo soldado espanhol Cieza de León e o mestiço Garcilaso de La Vega, expostas sem a mínima problematização e crítica. Já o livro Projeto Araribá: História 7 (2007), obra coletiva, desenvolvida e produzida pela Editora Moderna, contém um fragmento da narrativa de Hans Staden, marinheiro e mercenário alemão que esteve no Brasil entre os anos de 1548 e 1555. Intitulado "Encontro de culturas", o texto revela uma imagem generalizada dos índios como "selvagens" e derrotados num confronto bélico com os colonos portugueses na região dos Caetés, na capitania de Pernambuco. Trata-se de um conflito que ganha o sentido de "tumulto" promovido pelos indígenas, sem a mínima explicação, e que parece apenas impressionar pela superioridade bélica de noventa "cristãos aptos para a luta" capazes de derrotar 8 mil índios num combate (Moderna, 2007, p.207). Apesar de revelar uma resistência indígena às práticas colonialistas, o fragmento selecionado é pouco esclarecedor a esse respeito, já que aparece sem texto introdutório e com muitas supressões que impedem o entendimento do contexto e das razões dessa resistência. Deste modo, a narrativa acaba impondo uma visão dicotômica da conquista, que opõe e hierarquiza índios e portugueses de forma generalizada. Essa visão da conquista como um "encontro de culturas" desastroso para os indígenas, como bem observou Steve Stern (2006, p.63),

escapa à história dos ardis dos índios, de suas iniciativas, manipulações e resistências, que foram além do gesto inútil predestinado ao fracasso. Muitos povos ameríndios continuaram sendo suficientemente numerosos, socialmente coesos, economicamente dotados, politicamente comprometidos e culturalmente independentes para conduzir os colonizadores a vias de conflito, frustração, desilusão e luta que os europeus jamais haviam imaginado. [...] Essa obliteração não somente tende a desumanizar os índios ao reduzi-los a objetos

7 Esse livro é de autoria de Patrícia Ramos Braick e Myriam Becho Mota, lançado pela Editora Moderna em 2002. 
de abuso, exploração e proteção dos "outros" europeus, mas tende também, de modo mais irônico, a desumanizar os colonizadores europeus.

No livro didático, a narrativa de Hans Staden é destacada como fonte histórica ao lado de mais duas imagens: um desenho de Theodore de Bry [1562] que retrata os hábitos antropofágicos dos Tupinambá, e uma pintura de Johann Mortizs Rugedas [1835] que revela um conflito entre índios e soldados. As três fontes são alvo de atividades de comparação e descrição que não priorizam a reflexão crítica, nem a pesquisa sobre as suas condições de produção ou os significados de suas representações. Não por acaso, selecionamos um fragmento desse mesmo episódio, narrado por Hans Staden, para a composição do roteiro pedagógico exposto na segunda parte deste capítulo.

As narrativas coloniais, veiculadas nos livros didáticos, como meras ilustrações que fogem ao questionamento, ganham um status de verdade e acabam reforçando no imaginário dos estudantes as velhas representações colonialistas a respeito dos indígenas. Esse tipo de tratamento das fontes acaba por inibir a capacidade interpretativa dos estudantes, marcando-os como sujeitos passivos diante do conhecimento. Deste modo, as representações dos indígenas que circulam nos livros didáticos, marcadas por um discurso colonialista, podem constituir obstáculos na formação para a cidadania, negando aos povos indígenas o direito a uma história que veicule outros significados para suas identidades e atuação no passado (Silva; Grupioni, 1995).

As representações sociais possuem um caráter pedagógico, na medida em que são capazes de orientar e reger nosso sistema de interpretação do mundo, nossas identidades, memórias e práticas sociais. Há uma disputa no campo das representações que devem orientar os currículos escolares e os saberes históricos a serem ensinados e veiculados nos livros didáticos. Essa disputa é perpassada por relações de poder e dominação, por uma vontade de estabelecer verdades e impor valores e conceitos ligados a determinados grupos sociais. Não 
por acaso, a implementação da lei n.11.645/2008 que dispõe sobre a obrigatoriedade do estudo da História e Cultura indígena nos estabelecimentos de ensino fundamental e de ensino médio, públicos e privados, é fruto de lutas empreendidas por organizações indígenas e não indígenas, "que expressam também o desejo de que o ensino de História possa se tornar um aliado nos processos de valorização étnica e conquista de direitos fundamentais" (Bergamaschi, 2011, p.297).

Nos anos de 2010 e 2011, realizamos uma pesquisa nas escolas do Distrito Federal com o objetivo de identificar e analisar as representações dos indígenas no imaginário histórico dos estudantes de ensino médio. Os questionários aplicados para 146 estudantes revelaram que a América antiga ainda é vista, pela maioria dos estudantes, como um continente a ser "descoberto" e destinado à exploração colonial europeia. Apesar de reconhecerem a presença de populações indígenas antes da chegada dos europeus no continente, os estudante ainda destacam o protagonismo dos europeus na conquista e colonização, especialmente de personagens como Colombo e Cabral. Os questionários revelaram ainda que a maior parte dos estudantes teve acesso a essas informações na escola, o que indica a forte presença de representações eurocêntricas nos livros didáticos e nas aulas ministradas pelos professores. Com base nesta pesquisa vislumbramos a possibilidade de promover em sala de aula um novo olhar a respeito das narrativas coloniais e das representações dos indígenas difundidas por elas. As atividades pedagógicas com narrativas coloniais podem contribuir na qualificação da consciência histórica dos estudantes, permitindo também que eles se vejam como participantes e agentes da história (Abud et al., 2010, p.24).

Segundo Jodelet (2001, p.17), "representações sociais circulam nos discursos, são trazidas pelas palavras e veiculadas em mensagens e imagens", sejam elas midiáticas, historiográficas e didáticas, além disso, são "cristalizadas em condutas e em organizações materiais e espaciais". Considerando esse caráter educativo, impõe-se ao professor/pesquisador um reconhecimento das representações que povoam o imaginário histórico dos estudantes, bem como um trabalho cuidadoso de crítica e revisão dos livros didáticos, da historiografia e das 
fontes históricas que podem ser utilizados em sala de aula. No trabalho docente, as representações podem funcionar como instrumentos para a organização, problematização e seleção dos conteúdos e conceitos que serão tratados em sala de aula (Bittencourt, 2008, p.239).

No ensino de História as representações podem ser tomadas como objeto de problematização e reconstrução pelos próprios estudantes (Siman, 2005, p.350). Trata-se de uma proposta pedagógica que estimula os estudantes na percepção do modo como o social interfere na elaboração das representações e como esta elaboração interfere no social. Só assim podemos contribuir no estabelecimento de atitudes mais críticas e dialógicas diante do conhecimento, atentas aos processos de sua produção, às relações de poder que operam na construção/difusão de representações, bem como às práticas sociais que induzem e justificam.

Com base nessas considerações teórico-metodológicas apresentamos a seguir uma proposta de abordagem de um extrato de narrativa colonial nas aulas de História das séries finais do ensino fundamental. Esse roteiro encontra-se disponível para download no repositório digital do Projeto América Indígena, ${ }^{8}$ local em que os professores podem encontrar as orientações teórico-metodológicas de cada uma das etapas de atividades descritas nesse roteiro, ${ }^{9}$ além de extratos de narrativas coloniais, fichas temáticas, recursos audiovisuais, textos e indicações bibliográficas que podem auxiliá-lo no ensino de História indígena.

\section{Roteiro pedagógico}

\section{Tema}

Resistência dos índios à colonização portuguesa em Pernambuco (século XVI).

8 Disponível em: <http://www.americaindigena.com.br/>.

9 As concepções teórico-metodológicas que orientaram a elaboração de cada etapa de atividade estão descritas nos seguintes artigos de Oliveira (2011a, 2011b). 


\section{Nível dos estudantes}

Séries finais $\left(7^{\circ}, 8^{\circ}\right.$ e $9^{\circ}$ ano $)$ do ensino fundamental (quarto ciclo).

\section{Eixo temático (PCN's)}

História das representações e das relações de poder (Brasil, 1998, p.70).

\section{Objetivos}

- contribuir na formação do estudante como um cidadão crítico;

- promover um ensino de História centrado na historicidade e no protagonismo das sociedades indígenas;

- valorizar os estudantes como protagonistas da realidade social e da história e como sujeitos ativos no processo de aprendizagem;

- ler, comparar, debater e interpretar fontes históricas;

- estimular a pesquisa histórica na internet;

- propiciar reflexões sobre a relação presente-passado e criar situações didáticas para que o estudante conheça e domine procedimentos de como interrogar obras humanas do seu tempo e de outras épocas (Brasil, 1998, p.86);

- discutir o modo como as representações dos indígenas, presentes nas narrativas coloniais, puderam interferir na constituição das identidades e relações sociais no passado e no presente;

- estudar os processos de produção de sentidos, especialmente, as condições de produção dos discursos que descreviam as sociedades indígenas da América colonial;

- $\quad$ situar as representações dos indígenas, veiculadas nas narrativas coloniais, como construções baseadas em valores e conceitos que eram externos e estranhos aos próprios indígenas;

- produzir sentidos e significados para o passado, estimulando a imaginação histórica dos estudantes, por meio da produção de textos em sala de aula. 


\section{Fonte histórica}

STADEN, H. A verdadeira história dos selvagens, nus e ferozes devoradores de homens (1548-1555). Tradução Pedro Süssekind. 5.ed. Rio de Janeiro: Dantes, 2004 , p. $25-26 .^{10}$

\section{Cenário}

Durante a sua segunda viagem ao Brasil, o marinheiro e mercenário alemão Hans Staden (1525-1579) decidiu caçar sozinho fora dos limites do forte português em Bertioga e acabou sendo capturado e aprisionado por nove meses por índios Tupinambá. Após ser libertado e retornar à Europa, relatou os episódios de suas viagens e de seu aprisionamento e convivência com os Tupinambá. Em uma dessas narrativas, Hans Staden declara que em sua primeira viagem ao Brasil foi convocado, por volta de 1548, para conter uma revolta de índios contra os colonos portugueses na capitania de Pernambuco.

\section{Extrato}

\section{Capítulo Três}

Como os selvagens de Pernambuco revoltaram-se contra os portugueses, querendo destruir suas colônias

Embora não fosse de sua índole, os selvagens de Pernambuco haviam-se tornado revoltosos por culpa dos portugueses. O governador daquela terra pediu-nos, pelo amor de Deus, que corrêssemos para ajudar o povoado de Igaraçu, assaltado pelos selvagens. Igaraçu ficava à distância de 5 milhas do porto de Marin, nosso ancoradouro. Os moradores de Marin não podiam ir em auxílio a Igaraçu, já que eles mesmos temiam um ataque dos selvagens.

10 A obra completa pode ser encontrada no endereço: <http://www.brasiliana.usp. $\mathrm{br} / \mathrm{bbd} /$ handle/1918/01737100\#page/1/mode/1up $>$. 
Fomos ajudar os moradores de Igaraçu com quarenta homens de nossa tripulação. Com uma embarcação pequena, navegamos por um braço de mar, à beira do qual o povoado se encontrava cerca de 2 milhas terra adentro. Devíamos ser uns 90 defensores cristãos, contando ainda com 30 negros e escravos brasileiros, que pertenciam aos moradores de Igaraçu. Os selvagens que nos sitiavam eram estimados em 8 mil. Nossa única proteção era uma paliçada ao redor do povoado.

\section{Capítulo Quatro}

\section{A fortaleza dos selvagens e como eles batalhavam contra nós}

O povoado sitiado era cercado pela floresta. Ali, os selvagens ergueram duas fortificações feitas de troncos grossos de árvores, para onde recuavam à noite a fim de ficar seguros contra as nossas investidas. Em volta do povoado tinham feito buracos na terra, nos quais permaneciam durante o dia, e de onde saíam para combates menores. Quando atirávamos na direção deles, jogavam-se no chão para escapar dos disparos. Era assim que nos sitiavam, tornando impossível entrar ou sair do povoado. Também chegavam bem perto do povoado, atirando para alto muitas flechas que deviam atingir-nos na queda. Com a ajuda de cera e algodão, faziam também flechas incendiárias, com a intenção de atear fogo em nossos tetos, e ameaçam devorar-nos, caso nos apanhassem.

Visto ser habitual naquela terra colher raízes novas diariamente ou a cada dois dias, para fazer farinha e bolos, e como nós não tínhamos acesso a tais raízes, nossas provisões logo estariam esgotadas.

Percebemos a necessidade urgente de mantimentos, abrimos caminhos com dois barcos para o povoado. Mas os selvagens quiseram impedi-lo, e para isso tinham derrubado árvores grandes e por sobre o estreito braço de mar, sendo que as duas margens estavam ocupadas por muitos deles. Justo quando havíamos rompido a barreira, usando de violência, veio a hora da Mara baixa e deixou-nos encalhados no seco. Já que os selvagens não podiam apanhar-nos nos barcos, 
empilharam entre estes e a margem muita lenha seca. Quiseram atear fogo na lenha e então jogar nas chamas uma pimenta que crescia em grande quantidade naquela terra para nos expulsar do barco com a fumaça. Mas não conseguiram. Nesse intervalo a água voltou a subir, de modo que pudemos ir até Itamaracá, cujos habitantes nos deram mantimentos. Isso feito, retornamos para o povoado sitiado de Igaraçu. Mais uma vez os selvagens tentaram impedir nossa travessia. [...]

Seguimos adiante, rompendo a barreira. A primeira árvore caiu na trincheira deles, a segunda bateu na água, atrás de nosso barco. Antes mesmo de começarmos a travessia da barreira, pedimos ajuda aos companheiros no povoado. Mas, quando começávamos a chamar, os selvagens também gritavam. Ver-nos era impossível, já que os troncos e galhos tampavam a visão. Já estávamos perto o suficiente para sermos ouvidos, não fosse por aquela gritaria dos selvagens.

Conseguimos levar os mantimentos para o povoado e, quando os selvagens perceberam que não podiam fazer nada, pediram trégua e retiraram-se. O cerco durara quase um mês. Os selvagens tinham alguns mortos para lamentar, mas nós, cristãos, não tínhamos nenhum.

Como estávamos certos de que os selvagens manteriam a trégua, retornamos para a nossa nau, que ainda se encontrava diante de Marin. Lá nos abastecemos com um carregamento de água potável e farinha de mandioca. O comandante de Marin nos agradeceu.

\section{Atividades}

\section{Primeira etapa - introdução}

O professor deve verificar o conhecimento prévio dos estudantes, lançando as seguintes indagações: o que vocês sabem a respeito dos índios da época colonial? Como eles viviam antes da chegada dos colonizadores europeus? De que forma os portugueses viam e tratavam os indígenas nos primeiros anos da colonização do Brasil? Onde vocês encontraram informações sobre estas questões? 
Em seguida, os estudantes devem fazer uma pesquisa na internet sobre a vida e a obra literária de Hans Staden, que irá ajudar a identificar o tipo de fonte histórica, data e local de sua produção, conteúdos/ temas abordados, destinatários, formas de divulgação e condições de produção do extrato que será analisado em sala de aula. Os estudantes devem trazer para a sala de aula as informações coletadas nesta pesquisa. Esse material será utilizado na terceira etapa de atividades.

\section{Segunda etapa - leitura do extrato e decomposição de seus elementos}

Após a leitura do extrato, os estudantes devem realizar as seguintes atividades:

- identificar palavras desconhecidas, sublinhá-las e pesquisar os seus significados;

- identificar o assunto central;

- identificar os personagens, grupos ou acontecimentos mencionados no texto;

- identificar adjetivos e características dos personagens mencionados no texto.

\section{Terceira etapa - interpretação do extrato}

Os estudantes devem ler novamente a narrativa, desta vez a leitura pode ser coletiva. Em seguida, com a ajuda do material coletado na internet (ver a primeira etapa de atividades), os estudantes devem debater as seguintes questões:

- Quem é o autor da narrativa? O que ele fazia no Brasil no período colonial?

- Onde essa narrativa foi produzida? De que lugar fala o documento?

- Em que circunstância essa narrativa foi produzida e publicada? De que época trata o conteúdo do texto? 
- Que tipo de documentoé esse? Qual o seu formato e estrutura?

- A quem era destinado esse texto?

- Com que propósitos o autor escreveu esse texto?

- Qual a imagem dos indígenas na narrativa?

- O que significa o termo "selvagem"? Vocês acham justo essa denominação dos indígenas? Por que Hans Staden denominava os indígenas como selvagens? Vocês acham que essa imagem de "selvagem" ainda permanece nos dias atuais? Que tipo de relações sociais podem ser resultados da construção e proliferação dessa imagem dos indígenas como selvagens?

- Que diferenças culturais vocês percebem entre os portugueses e os indígenas da época colonial?

- $\quad$ que vocês pensam a respeito da escravidão indígena no período colonial?

Durante o debate, o professor deve ajudar os estudantes a pensar as imagens dos indígenas como construções sociais baseadas em interesses, crenças e valores e que, assim, as imagens históricas que aparecem na narrativa, bem como na mídia e outros artefatos da atualidade, são resultados de concepções e práticas de determinados grupos sociais. É neste caminho que o professor poderá contribuir na desconstrução de imagens históricas tidas como universais e naturais a respeito dos indígenas.

\section{Quarta etapa - estabelecendo relações entre o presente e o passado}

Questões para um breve debate em sala de aula: o que vocês acham da exploração do trabalho indígena em nossa sociedade? Vocês concordam com isso? Por quê?

Após o debate, os estudantes devem fazer a leitura de um texto publicado na internet, com o título "Exploração de indígenas nos canaviais do MS é histórica". ${ }^{11}$ Após essa tarefa, devem identificar

11 Disponível em: <http://www.reporterbrasil.org.br/exibe.php?id=1387>. 
palavras desconhecidas no texto e pesquisar seus significados. As questões para debate desse texto seriam: como a nossa sociedade lida com a exploração do trabalho indígena? Vocês percebem diferenças e semelhanças entre o presente (atualidade) e o passado colonial? Qual a imagem dos índios na televisão, nos jornais e nas revistas brasileiras? Como vocês interpretam essas imagens?

Na sequência, os estudantes deverão redigir individualmente um texto que contemple os seguintes elementos: imagem dos indígenas em nossa sociedade, resistências e lutas indígenas no Brasil e exploração do trabalho indígena no passado e no presente.

No final, o professor pode recuperar as "falas" dos estudantes, pronunciadas na primeira etapa de atividades, sobre os indígenas da época colonial, e tecer uma conclusão, identificando, com os alunos, mudanças e permanências entre as concepções iniciais e aquelas que apresentaram no texto produzido no final das atividades.

\section{Conclusão}

As atividades propostas no roteiro pedagógico buscam situar a narrativa colonial no tempo e espaço de sua produção, articulada aos acontecimentos de sua época. Deste modo, o estudante tem a possibilidade de perceber a historicidade dos conhecimentos históricos elaborados sobre os indígenas. Essa percepção permite o questionamento de imagens que foram tomadas como evidentes e naturais acerca da atuação dos indígenas no passado e que perpetuam uma memória histórica colonialista que marca os povos indígenas como seres inferiores, selvagens, atrasados e a-históricos.

Para que o ensino de História contribua no reconhecimento, respeito e valorização das sociedades indígenas, é necessário que promova em sala de aula uma historicização das representações que circulam nas fontes históricas, nos livros didáticos e no próprio imaginário dos estudantes. Essa proposta contribui amplamente na "descolonização" dos saberes apreendidos na escola, abrindo-se à 
pluralidade de interpretações e ao diálogo com diferentes perspectivas históricas e culturais acerca dos indígenas.

A leitura e interpretação de narrativas coloniais em sala de aula, tendo em vista a percepção do caráter histórico e de construção de suas representações, é fundamental tanto para a desnaturalização de representações negativas e estereotipadas acerca dos indígenas, como para a desconstrução do mito da história como verdade única e absoluta. Nessa perspectiva, o ensino de História pode se tornar um momento de compartilhamento de saberes, de construção de novos significados para as sociedades indígenas, de desenvolvimento de habilidades interpretativas, de estimulo à imaginação histórica, de exercício do conhecimento autônomo e crítico, e de aprimoramento da cidadania e democracia.

\section{Referências bibliográficas}

ABUD, K. M.; SILVA, A. C. de M. S.; ALVES, R. C. Ensino de história. São Paulo: Cengage Learning, 2010.

ARRUDA, A. O ambiente natural e seus habitantes no imaginário brasileiro Negociando a diferença. In: . (Org.). Representando a alteridade. Petrópolis (RJ): Vozes, 1998.

BERGAMASCHI, M. A. A temática indígena no ensino de história: possibilidades para diálogos interculturais? FONSEVA, S. G.; JÚNIOR, D. G. (Orgs.). Perspectivas do ensino de história: ensino, cidadania e consciência histórica. Uberlândia: Edufu, 2011.

BITTENCOURT, C. M. F. Ensino de história: fundamentos e métodos. 2.ed. São Paulo: Cortez, 2008.

BONIN, I. T. Problematizando narrativas sobre os povos indígenas: um olhar sobre o "descobrimento", a nação e outras histórias que contamos nas escolas. Ciências Humanas em Revista, São Luís, UFMA, v.4, p.61-72, 2006.

BRAICK, P. R.; MOTA, M. B. História das cavernas ao Terceiro Milênio. 2.ed. São Paulo: Moderna, 2002.

BRASIL. Secretaria de Educação Fundamental. Parâmetros Curriculares Nacionais. Terceiro e quarto ciclos do Ensino Fundamental. História. Brasília: MEC/SEF, 1998. 
BRASIL. Ministério da Educação/Secretaria da Educação Continuada, Alfabetização e Diversidade. Orientações e ações para a educação das relações étnico-raciais. Brasília: Secad, 2006.

DIAS, J. S. da S. Os descobrimentos e a problemática cultural do século XVI. Coimbra: Universidade de Coimbra, 1973.

EDITORA MODERNA (Org.). Projeto Araribá: História 7. Ensino Fundamental: 6 ${ }^{a}$ Série. Obra coletiva. 2.ed. São Paulo: Editora Moderna, 2007. (Editora executiva: Maria Raquel Apolinário.)

JODELET, D. (Org.). As representações sociais. Rio de Janeiro: Uerj, 2001.

JOVCHELOVITCH, S. Re(des)cobrindo o outro - para um entendimento da alteridade na teoria das representações sociais. In: ARRUDA, A. (Org.). Representando a alteridade. Petrópolis: Vozes, 1998.

FONSECA, S. G. Didática e prática de ensino de história: experiências, reflexões e aprendizados. São Paulo: Papirus, 2003.

FOUCAULT, M. arqueologia do saber: Forense Universitária, 1986.

NATALINO, E. dos S. As tradições históricas indígenas diante da conquista e colonização da América: transformações e continuidades entre nahuas e incas. Revista de História, São Paulo, FFLCH/USP, n.150, $1^{\circ}$ semestre de 2004.

NAVARRO-SWAIN, T. Os limites discursivos da história: imposição de sentidos. Labrys: Revista de Estudos Feministas, n.9, 2006. Disponível em: <http://www.unb.br/ih/his/gefem/labrys9/libre/anahita.htm>. Acesso em: 2/6/2006.

NETO, E. F. História e etnia. In: CARDOSO, C. F.; VAINFAS, R. (Orgs.). Domínios da história: ensaios de teoria e metodologia. Rio de Janeiro: Elsevier, 1997.

NEVES, L. F. B. O combate dos soldados de cristo na terra dos papagaios: colonialismo e repressão cultural. Rio de Janeiro: Forense Universitária, 1978.

OLIVEIRA, S. R. de. As crônicas coloniais e a produção de sentidos para o universo incaico e o passado das origens do Tawantinsuyo. Revista Dimensões (Dossiê: América, Américas), Vitória, Universidade Federal do Espírito Santo, v.20, 2008.

As crônicas coloniais no ensino de História da América. Revista História E Ensino, Londrina, Laboratório de Ensino de História da Universidade de Londrina, v.17, n.2, 2011a.

As crônicas espanholas do século XVI e a produção de narrativas históricas sobre a América e seus habitantes. Revista Em tempo de Histórias, Brasília, UnB, v.5, ano 5, 2002. 
OLIVEIRA, S. R. de. Representações das sociedades indígenas nas fontes históricas coloniais: propostas para o ensino de História. Revista Anos 90 (Dossiê: História Indígena na América), PPGH-UFRGS, n.34, 2011b.

ORLANDI, E. P. Análise de discurso: princípios e procedimentos. 5.ed. Campinas: Pontes, 2003.

Por uma história do possível: representações das mulheres Incas nas crônicas e na historiografia. Jundiaí (SP): Paco Editorial, 2012.

Terra à vista. Discursos do confronto: velho e novo mundo. Campinas/ São Paulo: Unicamp/Cortez, 1990.

(org.). Discurso fundador, a formação do país e a construção da identidade nacional. 3.ed. Campinas: Pontes, 2003.

PEASE, F. G. Y. Las crónicas y los Andes. 1.ed. Lima: Pontificia Universidade Católica del Perú, 1995; México/EUA: Fondo de Cultura Económica, 1994.

PEREIRA, A. L. Uma contribuição à teoria pós-colonialista: notas sobre a obra de Abdias do Nascimento. Anais do II Seminário Nacional Sociologia e Política. Paraná, Curitiba, 2010.

PRYSTHON, A. Mapeando o pós-colonialismo e os estudos culturais na América Latina. Revista da Anpoll, São Paulo, v.1, n.10, p.23-46, 2001.

SCHMIDT, M. A.; CAINELLI, M. Ensinar história. São Paulo: Scipione, 2004.

RAGO, M. Epistemologia feminista, gênero e história. In: PEDRO, J. M.; GROSSI, M. Masculino, feminino e plural. Florianópolis: Ed. das Mulheres, 1998.

SIMAN, L. M. de C. Representações e memórias sociais compartilhadas: desafios para os processos de ensino e aprendizagem da história. Cadernos Cedes [online], v.25, n.67, p.348-364, 2005.

SILVA, A. L. da; GRUPIONI, L. D. B. A temática indígena na escola: novos subsídios para professores de $1^{\circ}$ e $2^{\circ}$ graus. Brasília: MEC/Mari/Unesco, 1995.

STADEN, H. A verdadeira história dos selvagens, nus e ferozes devoradores de homens (1548-1555). Tradução Pedro Süssekind. 5.ed. Rio de Janeiro: Dantes, 2004.

STERN, S. J. Paradigmas da conquista, história, historiografia e política. In: BONILLA, H. (org.). Os conquistados: 1492 e a população indígena das Américas. São Paulo: Hucitec, 2006.

ZAMBONI, E. Representações e linguagens no ensino de História. Revista Brasileira de História, São Paulo, v.18, n.36, 1998. 


\section{PARTE II \\ Narrativas E ICONOGRAFIA SOBRE A AMÉRICA INDÍGENA}




\section{IDEALIZAÇÃO, EXALTAÇÃO E DEGENERAÇÃO DA NATUREZA E DOS HABITANTES DO BRASIL NOS RELATOS DOS VIAJANTES EUROPEUS DURANTE O SÉCULO XVI E INÍCIO DO SÉCULO XVII}

Vinícius Pires*

Inicialmente, cabe aqui mencionar que, no século XVI, os índios considerados do Brasil encontravam-se na porção territorial concedida a Portugal pelo Tratado de Tordesilhas, logo, foram as nações litorâneas de língua guarani, e principalmente tupi, que contribuíram para a formação das primeiras imagens acerca dos indígenas brasileiros. Os relatos sobre esses povos ficaram, na primeira metade do XVI, restritos quase que exclusivamente às cartas de Pero Vaz de Caminha e de Américo Vespúcio. Somente a partir da década de 1550 que o conhecimento sobre o novo território e seus habitantes se tornou mais detalhado, graças à chegada dos jesuítas em 1549 e aos constantes intercâmbios costeiros entre índios e viajantes de outros reinos, como os franceses. Assim, nesse período, segundo a historiadora Manuela Carneiro da Cunha, podemos pensar os relatos de viagem através da divisão básica entre autores ibéricos, ligados diretamente à colonização, como os missionários e os administradores, e autores não ibéricos, ligados ao escambo, para quem a natureza e os índios eram matéria de reflexão muito mais que de gestão. ${ }^{1}$

* Doutorando pelo Programa de Pós-Graduação em História da Faculdade de Ciências Humanas e Sociais da Unesp (câmpus de Franca).

1 Cf. Cunha (1990, p.95). 
Em meados do século XVI e início do XVII, o Brasil foi palco de incessantes conflitos entre portugueses e franceses. Estes, por sua vez, logo formaram pequenas redes comerciais com os indígenas e tentaram por duas vezes criar possessões em terras brasileiras. A primeira tentativa ocorreu durante a constituição da França Antártica, iniciada em 1555 e que perdurou até 1560, na qual os franceses procuraram estabelecer uma colônia na Baía de Guanabara, no Rio de Janeiro. Dentre os principais motivos para o fracasso, fizeram-se presentes as disputas internas entre os próprios franceses, entre católicos - liderados por Nicollas de Villegagnon, rígido comandante da França Antártica - e reformados.

Nas décadas seguintes, a costa brasileira foi sucessivamente povoada por portugueses, entretanto, houve uma segunda tentativa francesa, também fracassada, que procurou estabelecer uma colônia na região Norte do Brasil, no litoral do atual Estado do Maranhão: a França Equinocial, fundada em 1612 e que perdurou até 1615. Um dos motivos para o fracasso desta empreitada foi a inferioridade numérica de homens e de material bélico diante das tentativas de reconquista do território pelas frotas e incursões portuguesas. Neste período em que o interesse pelo Brasil aumentou, cresceu também a produção escrita sobre o Novo Mundo, e dois elementos recorrentes nessas narrativas, como não poderia ser diferente, são os habitantes e as características naturais das novas terras. Assim, para encontrarmos as primeiras descrições acerca dos nativos e da natureza da costa brasileira, precisamos recorrer aos relatos, embora não tão abundantes, ${ }^{2}$ de portugueses e franceses.

2 Em 1591, uma década após a União Ibérica, tornou-se proibida a vinda de navios estrangeiros para a América portuguesa. Já em 1605, impossibilitou-se a presença deles na colônia e foi estipulado o prazo de um ano para que os já residentes retornassem aos seus respectivos países de origem. Tais restrições, ainda que não tenham sido severamente respeitadas, dificultaram as visitas de estrangeiros ao país. Ademais, não esqueçamos os concorrentes interesses pela Índia e pela China nos séculos XVI e XVII. O interesse pelo continente Austral tornou-se majoritário apenas no século XVIII. 


\section{Exaltação e degeneração da natureza}

Tanto em relação à natureza quanto em relação aos habitantes, são as cartas de Américo Vespúcio, cosmógrafo da segunda expedição enviada por Dom Manuel e viajante responsável por cunhar a expressão "Novo Mundo", ${ }^{3}$ que tornaram notável a Terra de Santa Cruz nos ambientes letrados europeus. ${ }^{4}$ Em missiva datada de 1503 e destinada a Lorenzo di Médici, depois de relatar o quão exóticos eram os hábitos da gente que vivia nas novas terras, ele dissertou acerca das potencialidades da natureza:

A terra daquelas regiões é muito fértil e amena, com muitas colinas, montes, infinitos vales, abundantes rios, banhada de saudáveis fontes, com selvas densas, pouco penetráveis, copiosa e cheia de todo o gênero de feras. Ali principalmente as árvores crescem sem cultivador, muitas das quais dão frutos deleitáveis no sabor e úteis aos corpos humanos.

[...]

Se quisesse lembrar de cada coisa que ali existe e escrever sobre os numerosos gêneros de animais e a multidão deles, a coisa se tornaria totalmente prolixa e imensa.

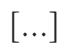

3 O pensamento deVespúcio é bastante claro se associado ao seu contexto cultural. Para o viajante, como para qualquer coetâneo seu, a palavra "mundo" referia-se ao orbis terrarum, a porção do globo que compreendia Europa, Ásia e África e que havia sido destinada por Deus ao homem. Se a ele pareceu lícito designar as regiões recém exploradas como um "novo mundo" é porque as imaginou como um dos tais orbis alterius admitidos pelos pagãos, mas não aceitos pelos autores cristãos, pois podiam implicar uma inaceitável e herética pluralidade de mundos. Logo, o que aconteceu foi que Vespúcio, atento à possibilidade empírica de continuar explicando como asiáticas as terras que explorou e ao verificar, portanto, que estava na presença de uma entidade geográfica desconhecida, recorreu a esse conceito, que abandonou em um breve espaço de tempo por ser uma solução inaceitável. Cf. O' Gorman (1992).

4 A primeira carta portuguesa sobre a então Terra de Vera Cruz e seus habitantes, escrita em 1500 por Pero Vaz de Caminha, permaneceu inédita nos arquivos da Coroa até 1773. 
Ali todas as árvores são odoríferas e cada uma emite de si goma, óleo ou algum líquido cujas propriedades, se fossem por nós conhecidas, não duvido de que seriam saudáveis aos corpos humanos. Certamente, se o paraíso terrestre estiver em alguma parte da Terra, creio não estar longe daquelas regiões, cuja localização [...] é para o meridiano, em tão temperado ar que ali nunca há invernos gelados nem verões férvidos. (Vespúcio, 2003, p.43-5)

De maneira geral, comum a todo o corpo documental produzido no século XVI e início do século XVII em relação à natureza brasileira, se fizeram presentes referências aos quatro tópicos mencionados pelo navegante florentino, a saber, a fertilidade do solo, a variedade da fauna, a exuberância da flora e o clima ameno.

Acerca do clima, o inaciano José de Anchieta, além de ratificar as impressões iniciais de Vespúcio, retomou esse ponto de maneira pormenorizada, estabelecendo, inclusive, uma comparação entre os fenômenos climáticos da Europa e do Brasil e, assim, acabou por reconhecer as vantagens dos ares temperados da colônia:

As estações do ano são aqui inteiramente avessas às de lá; no tempo em que lá é primavera e cá é inverno e vice-versa; mas são tão temperadas que não faltam no inverno os calores do sol para suavizar o rigor do frio, nem no verão as brandas brisas e as úmidas chuvas para regalo dos sentidos [...] essa terra, da beira-mar, é quase todo o ano regada por águas da chuva.

$[\ldots]$

O Sol nos seus giros produz uma temperatura constante, de maneira que nem o inverno regela com o frio, nem o verão é demasiado quente [...] em nenhum tempo do ano param as chuvas, e, de quatro em quatro, de três em três ou até de dois em dois anos, se alterna a chuva com o sol. (Anchieta, 1954, p.101-2)

Também impressionado com a temperança dos ares no Brasil, conhecidamente localizado na então denominada "zona tórrida" do globo terrestre (Randles, 1994), o piloto francês Nicolas Barré, no 
contexto de implantação da França Antártica na Baía de Guanabara, escreveu que a temperatura, "ao contrário do que diziam os antigos, pareceu-nos bastante temperada" e, continuando suas anotações, justificou, segundo suas perspectivas, o porquê da nudez dos índios: "de tal modo que os homens que estavam vestidos não precisaram de se despir e os que estavam despidos não careceram de se cobrir" (Barré, 2000, p.133).

Além desses aspectos positivos, o clima agradável, neste período inicial da colonização, ${ }^{5}$ ganhou características bastante nobres e chegou a ser o responsável, como pontuou Vespúcio, pela excelente condição da terra: "ali o ar é muito temperado e bom e, pelo que pude conhecer $[. .$.$] nunca houve peste ou outra doença no solo oriunda da$ corrupção do ar" (Vespúcio, 2003, p.45). Outra sublime qualidade atribuída ao clima era a de que ele se fazia um dos elementos responsáveis pela saúde, tanto dos nativos quanto daqueles que permaneciam em território brasileiro: o missionário Luís da Grã, ao relatar o árduo trabalho de catequização exercido por ele com os pequenos indígenas e com os filhos dos colonos, não deixou de exaltar o caráter terapêutico dos bons ares da terra:

as ocupações eram de ensinar os meninos que a cargo temos e ter cuidado de dar ordem ao que era necessário para sustentação dos meninos, que é farto trabalho para sua disposição [...] que por graça do Senhor foi sempre em muito notável aumento, vindo do Reino sem remédio humano de saúde, porque não puderam fazer tantos os muitos que o procuraram no Reino, quanto fez a terra com tão bons ares como tem, que sem dúvida os velhos e de fraca compleição a sentem muito a propósito para sua saúde corporal, e de todas as partes do Brasil se diz o mesmo. (Grã, 1954, p.130)

5 Dos quatro pilares suscitados por Américo Vespúcio acerca da natureza brasileira, o clima foi o único que passou por uma ressignificação pejorativa durante o período colonial: o clima ameno do século XVI deu lugar, já em meados do século XVII e durante todo o século XVIII, a um clima demasiadamente quente, o que tornava o Brasil, segundo o ponto de vista da grande maioria dos viajantes estrangeiros, um local insalubre e um tanto quanto inóspito. Cf. França (2010). 
Manuel da Nóbrega, diretor espiritual da primeira missão jesuítica que desembarcou na América portuguesa em 1549, pontuou o estranhamento de seus subordinados ao novo cotidiano em território desconhecido - principalmente com relação à alimentação - e, com isso, também relacionou a condição climática à boa saúde daqueles que passavam a usufruí-la:

muito sã e de bons ares, de tal maneira que sendo a gente muita e ter muito trabalho, e haver mudados os mantimentos com que se criaram, adoecem muito poucos e esses que adoecem logo saram. É terra muito fresca, de inverno temperado, e o calor do verão não se sente muito. (Nóbrega, 1954, p.135)

Outra temática, que cedo passou a marcar constante presença nos relatos acerca do Brasil, foi a fertilidade da terra que, por sua vez, segundo os viajantes e os religiosos, estava diretamente ligada à boa condição do clima. Além de evidenciar essa ligação, Nóbrega dissertou sobre a condição favorável de habitar/colonizar a terra ao estabelecer uma comparação direta entre os frutos gerados pelo solo e as condições de pecuária no Brasil em relação à Europa:

o inverno não é frio, nem quente, e o verão ainda seja mais quente, não se pode sofrer [...] é terra muito úmida, pelas muitas águas, que chove em todo tempo muito a miúdo, pelo qual os arvoredos e as ervas estão sempre verdes. Há nela diversas frutas, que comem os da terra, ainda que não sejam tão boas como as de lá, as quais também creio que se dariam cá se as plantassem. Porque veio dar-se parras, uvas, e ainda duas vezes no ano [...] cidras, laranjas, limões dão-se em muita abundância; e figos tão bons como os de lá. O mantimento comum da terra é uma raiz de pau, que chamam mandioca, da qual fazem uma farinha que comemos todos. E dá também milho, o qual misturado com a farinha faz-se um pão, que escusa o de trigo. Há [...] muita caça de matos, e gansos que criam os índios. Bois, vacas, ovelhas, cabras e galinhas se dão também na terra, e há deles muita cópia. (Nóbrega, 1954, p.147-8) 
Nesta passagem, percebe-se o esforço do inaciano em noticiar que as condições de vida na jovem colônia portuguesa, apesar de não terem sido fáceis, foram humanamente possíveis, uma vez que, segundo as suas palavras, as diferenças naturais entre este e aquele lado do Atlântico não se apresentaram completamente antagônicas. Dito de outro modo, para Nóbrega, os problemas existentes e as possíveis limitações futuras impostas pela natureza ficariam em segundo plano diante da prodigalidade da terra.

O mesmo jesuíta, em carta de agosto de 1549, relatou ao padre Simão Rodrigues que a fertilidade dessas plagas permitiria o povoamento até mesmo com algumas mulheres de vida libertina, desde que elas "não fossem tais que de todo tenham perdido a vergonha a Deus e ao mundo", argumentando que

todas casariam muito bem, porque é terra muito grossa e larga, e uma planta que se faz uma vez dura dez anos aquela novidade, porque, assim como vão apanhando as raízes, plantam logo os ramos que logo arrebentam. De maneira que logo as mulheres teriam remédio de vida, e estes homens remediariam suas almas, e facilmente se povoaria a terra. (Nóbrega, 1954, p.120)

A fertilidade do solo serviria, portanto, como ingrediente básico na recuperação dos comportamentos desregrados dos homens e, principalmente, das "mulheres perdidas" e sem ocupação em Portugal. Segundo Nóbrega, a fertilidade natural impulsionaria e permitiria a fertilidade humana e, dessa maneira, os colonizadores teriam em mãos mais uma estratégia para o povoamento colonial.

Ademais, essa concepção de solo fértil apareceu atrelada às ideias de fartura e de vastidão territorial. $\mathrm{O}$ viajante italiano Antonio Pigafetta, membro da expedição iniciada em 1519 sob o comando de Fernão de Magalhães, escreveu que a terra da América portuguesa apresentava-se "abundante em toda classe de produtos, sendo a mesma tão extensa como França, Espanha e Itália juntas" (Pigafetta, 1985, p.75). Essa vinculação entre solo generoso e fartura de víveres foi um elemento que também despertou a atenção de Jean de Léry, 
pois, em seus escritos, se lê a seguinte passagem: "como este país dos nossos tupinambás tem a capacidade de alimentar dez vezes mais gente do que atualmente, posso gabar-me de ter tido às minhas ordens mais de mil jeiras de terras melhores que as de Beauce" (Léry, 1972, p.117). E, na maioria das vezes, essa abundância de elementos naturais, inclusive daqueles que detinham alto valor comercial no mercado europeu, era alcançada, segundo Claude d'Abbeville, sem esforço algum:

O que se tira agora da terra consiste em pau-brasil, madeiras preciosas e outras. Colhe-se também o algodão, o urucu, espécie de tinta vermelha muito abundante e também outra tinta encarnada que se assemelha à laca. Encontra-se também [...] o bálsamo verdadeiro como na Arábia. Prepara-se também muito tabaco, planta muito conhecida e que aí se encontra em abundância e é muito procurada, alcançando bom preço na França, nas Flandres e na Inglaterra.

$[\ldots]$

Acha-se comumente âmbar pardo ao longo da costa habitada pelos canibais. Há uma espécie de jaspe verde de que fazem pedras para os lábios; também rochas de cristal vermelho ou branco, mais duras do que as pedras ou diamantes ditos de Alençon e com outras particularidades. (Abbeville, 2002, p.162-3)

Enfim, Anchieta considerou a potencialidade dessa mesma terra, fecunda e vasta, também no tratamento de males que eram difíceis de serem curados em Portugal. O solo e uma curiosa metodologia terapêutica, até então nunca vista pelo inaciano, levaram-no a descrever o tratamento do cancro, cuja cura ele atestou ter comprovado:

o cancro, que lá é tão difícil de curar, cura-se facilmente pelos índios. Eles à doença, que é a mesma que entre nós [...] curam-na assim: do barro, de que fazem vasilhas, aquecem ao fogo um pouco, bem amassado e, tão quente quanto a carne o possa suportar, aplicam-no aos braços em cancro, que pouco a pouco morrem; e repetem isto tantas vezes até que, mortas as pernas e o corpo, o cancro desprende-se e 
cai por si. Há pouco se provou isto por experiência com uma escrava dos portugueses quando padecia de doença. (Anchieta, 1954, p.122)

Destarte, por mais que se tenha pontuado algumas comparações realizadas pelos viajantes, colonizadores e clérigos entre o clima e a fertilidade da terra do Brasil e da Europa, com relação à exuberância da flora e à variedade da fauna, presentes desde a modelar descrição de Américo Vespúcio, percebe-se maior cuidado na descrição das plantas e dos animais e, por isso, tornou-se exercício corriqueiro subdividi-los em duas categorias comparativas: uma em que eles se "assemelham aos nossos" e outra em que eles se "diferem dos nossos". Essa foi uma prática comum realizada pela maioria daqueles que estiveram na América portuguesa quinhentista e no início do Seiscentos, pois uma alteridade desconhecida pode ser abordada apenas através de esquemas extraídos de prévios conhecimentos, portanto, a projeção dos esquemas culturais familiares ao observador é, numa primeira fase, necessária para organizar os fatos se não mesmo para ter a percepção deles. ${ }^{6}$ Essa prática comparativa entre o "velho" e o "Novo Mundo" teria sido a força motriz da construção do conhecimento europeu no período supracitado. ${ }^{7}$

Retomando a análise documental, falemos agora da exuberância da flora. Depois de dissertar acerca da temperança do clima da colônia, Manuel da Nóbrega, uma vez mais recorrendo à comparação, teceu as suas primeiras impressões sobre a vegetação do litoral baiano:

Tem muitas frutas e de diversas maneiras, e muito boas e tem pouca inveja as de Portugal. Os montes parecem formosos jardins e hortas, e certamente nunca eu vi tapete de Flandres tão formoso, nos quais andam animais de muitas diversas maneiras, do quais Plínio nem escreveu nem supôs. Tem muitas ervas de diversos odores e muito diferentes das d'Espanha, e certamente bem resplandece a

6 Cf. Ginzburg (1991. p.163).

7 Cf. Foucault (1999, p.23). 
grandeza, formosura e saber do Criador em tantas, tão diversas e formosas criaturas. (Nóbrega, 1954, p.136)

Aliado a essa exaltação da flora, encontramos em todo o corpus documental estudado o reconhecimento de características terapêuticas nas plantas e em seus frutos, ${ }^{8}$ ou seja, as potencialidades da flora brasileira, desde muito cedo, passaram a ser diretamente associadas às características e práticas médicas do período. ${ }^{9}$ Yves d'Evreux, líder capuchinho na França Equinocial, apesar de não explorá-las com afinco, pontuou as qualidades curativas do bioma vegetal maranhense: "a terra é vigorosa, fértil e muito [...] estável para o plantio. As árvores da região são de tamanho avantajado, estão sempre verdes até o topo e contam com madeiras excelentes, seja pela cor, seja pelas suas propriedades medicinais” (Evreux, 2002, p.92).

Se por um lado alguns dos "desbravadores" das "novas terras", mesmo reconhecendo a atraente exuberância da flora, não dedicaram especial atenção à sua pormenorizada descrição, por outro lado, a grande maioria deles dedicou um número considerável de páginas de suas cartas e obras acerca do assunto, como foi o caso do viajante português Pero de Magalhães Gandavo, quando escreveu sobre as propriedades curativas de uma espécie de arbusto e, ademais, preocupou-se em registrar a melhor época do ano para lhe tirar o óleo terapêutico e também a maneira mais eficiente para retirá-lo do interior da planta sem desperdiçá-lo:

Certo gênero de árvores, encontradas mato adentro na capitania de Pernambuco, a que chamam copaíbas, de que se tira bálsamo muito benéfico e proveitoso em extremo para enfermidades de muitas

8 Esse reconhecimento, segundo o padre Fernão Cardim, também pôde ser observado em algumas espécies de primatas, dentre as quais, os macacos bugios: "dizem os naturais que alguns destes, quando lhes atiram uma flecha, a tomam na mão e tornam com ela atirar às pessoas [...] e quando os ferem buscam certa folha, a mastigam e a colocam na ferida para sararem" (Cardim, 1978. p.29).

9 Sobre a medicina do período anterior às clínicas, consultar, entre outros trabalhos, o catálogo Cardoso, Oliveira, Marques (2010). 
maneiras, principalmente das que procedem da frialdade: causa grandes efeitos e tira todas as dores por graves que sejam em muito breve espaço de tempo. Para feridas ou quaisquer outras chagas tem a mesma virtude, aos quais tanto que com ele lhe acodem, saram muito depressa, e tira os sinais de maneira que de maravilha se enxerga onde estiveram e nisto faz vantagem a todas as outras medicinas. Esse óleo não se acha todo o ano nestas árvores, nem procuram ir buscá-lo senão no estio que é o tempo em que assinaladamente o criam. E quando querem tirá-lo, golpeiam ou furam os troncos delas, pelos quais, pouco a pouco, gotejam de seus âmagos esse licor precioso. (Gandavo, 1980, p.38)

Anchieta, ao citar outra árvore "digna de notícia" da qual também se extraia um líquido viscoso, mas este com poderes para tratar as feridas do corpo, realizou o mesmo roteiro seguido por Gandavo em sua descrição, incluindo o modus operandi para que se chegasse ao líquido precioso:

Das árvores uma parece digna de notícia, da qual, ainda que outras bagas que destilam um líquido semelhante à resina, escorre um suco suavíssimo, útil para remédio, que pretendem seja o bálsamo, que a princípio corre como óleo por pequenos furos feitos por talhos de foices ou de machados, coalha depois e parece converter-se em uma espécie de bálsamo. Exala um cheiro muito forte, porém suavíssimo e é ótimo para curar feridas, de tal maneira que em pouco tempo, como dizem ter-se por experiência provado, nem mesmo sinal fica das cicatrizes. (Anchieta, 1988, p.316)

Assim sendo, percebe-se que esses homens buscaram em seus relatos comunicar o conhecimento que, paulatinamente, conseguiram acumular acerca dos usos práticos do reino vegetal brasileiro, dos seus valores medicinais e alimentícios, proporcionando, portanto, delineadas descrições das particularidades de cada espécie com a qual estabeleciam contato. 
Ademais, para esses colonizadores, catalogar a flora e também a fauna brasileira não se resumiu em uma atividade que buscou na natureza apenas os elementos de poderio econômico, mas também foi uma maneira de encontrar os elementos naturais capazes de engendrar o remédio que pudesse curar todos os males físicos e morais, a panaceia, além de servir como proteção diante das diferentes ameaças que a própria natureza apresentava. O colono Gabriel Soares Sousa, ao apresentar uma planta que crescia ao longo da costa da Bahia, chamada mucunã, escreveu:

essas favas para comer são peçonhentas, mas têm grande virtude para curar, com elas, feridas velhas desta maneira: depois de serem estas favas bem secas, hão-se de pisar muito bem, e cobrir as chagas com os pós delas, as quais comem todo o câncer e carne podre. (Sousa, 1971, p.205)

No relatório redigido pelo jesuíta António Blázquez, encontra-se a passagem de algumas atividades onde participaram os padres João Gonçalves e José de Anchieta, dentre as quais, destaca-se um episódio de curandeirismo praticado a contragosto de uma nativa convertida ao cristianismo:

entre outras enfermidades que com a ajuda sarou, foi essa uma, que estando uma índia muito ao cabo de diarreias, e não tendo remédio os parentes com que as estancar, lhe fizeram eles uns emplastros com acelga e azeite, porque cá não há outros materiais, e logo a deu sã, ficando por essa cura acerca dos negros em grande reputação. (Blázquez, 1954, p.355)

Nesse contexto, a flora brasílica foi de grande importância para o processo de colonização, tanto português quanto francês, uma vez que nas plantas nativas poderiam ser encontrados extratos para chás medicinais, emplastros, garrafadas e xaropes. Até mesmo a oposição clerical com relação às drogas e aos remédios, considerados, durante a Idade Média, exercícios de bruxaria e subterfúgios contrários à 
moral cristã, não apenas abrandou-se no período quinhentista como também as plantas da América e os remédios adquiridos através delas passaram a ser observados e testados com bastante seriedade pelos próprios religiosos. ${ }^{10}$

Ainda se tratando da vegetação costeira do Brasil, por fim, o francês Nicolas Barré, que desembarcou na Baía de Guanabara em 1556, também reconheceu a potencialidade terapêutica das plantas, mas deixou claro em sua escrita que ainda havia muito a se explorar e a se descobrir nos grandes territórios "selvagens", a ponto de deixar um estudioso do assunto, em relação ao desconhecido, incomodado:

A terra produz, ainda, favas grandes e pequenas, ambas muito boas para comer, e uma quantidade pouco significativa de cana-de-açúcar. Também em pequena quantidade são os limões e laranjas aqui encontrados. Quanto às plantas medicinais, eu encontrei somente a beldroega, o mirto e o manjerico. Todo o resto é tão selvagem e grande que, se mestre Jean, o herbanário, aqui estivesse, ficaria, sem dúvida, bem embaraçado. (Barré, 1999, p.21)

Em relação à fauna e sua variedade, presentes desde o relato de Vespúcio, também encontramos as propriedades terapêuticas atreladas a certas espécies de animais, como foi o caso da anhuma, ave brejeira que possui uma extensão óssea frontal de onde era extraído, por raspagem, um pó, que, à semelhança deste procedimento realizado com o chifre do rinoceronte, era considerado, depois de misturado em água pura, um soro poderoso contra todos os venenos. ${ }^{11} \mathrm{O}$ inaciano Jácome Monteiro, em 1610, noticiou uma situação em que o corno da anhuma foi utilizado:

A ponta desta ave, dizem os índios, que restitui a fala a quem a perde. A um padre nosso sucedeu o seguinte caso. Estava uma índia havia cinco dias sem fala [...] rezou-lhe o Evangelho de São Marcos

10 Cf. Carneiro (1994, p.55). Sobre o assunto, consultar também Fleck $(2010$, 2012).

11 Sobre as práticas curativas no Brasil colonial, consultar Ribeiro (1997). 
e, juntamente, lhe lançou ao pescoço a ponta dessa ave, e logo súbito falou e sarou. Demos essa maravilha ao Santo Evangelho, contudo me dizem que é experiência de muitos anos, entre estes índios, e que acham ser aprovado. (Monteiro, 2000, p.425) ${ }^{12}$

Além dessa característica singular encontrada no pássaro acima citado, as aves do continente Austral atraíram de imediato a atenção dos colonizadores, a ponto do frade e cosmógrafo francês André Thevet dedicar um capítulo inteiro de sua obra a elas: "Das aves mais comuns na América” (Thevet, 1978, p.291-296). Por toda a costa brasileira, desde o norte até o sul, a quantidade e a variedade desses curiosos animais não passaram despercebidas: "é impossível dizer quantas espécies de pássaros se encontram na ilha do Maranhão e circunvizinhanças, muito diferentes todos dos nossos" (Abbeville, 2002, p.182); assim como também não deixaram de constar, em diversas narrativas, apontamentos acerca de seu vigor e de suas cores chamativas: "à entrada do rio da Guanabara, encontramos abundância de peixes e outros animais, mas as aves, além de abundantes, são tão diversas das nossas nas cores que lhe são peculiares" (Léry, 1972, p.153).

Já os peixes, em linhas gerais, não foram considerados amplamente distintos em relação aos que viviam nas águas europeias, portanto, os colonizadores, ao mencioná-los, escreveram que suas carnes eram agradáveis ao paladar, que eram encontrados em grandes cardumes e enfatizaram as estratégias de pesca praticadas pelos indígenas:

os adultos pescam peixes maiores, que são também abundantes nos rios. A maneira de pescar que empregam é a seguinte: inteiramente despidos, na água doce ou salgada, acertam o peixe com suas flechas, no que são muito destros, puxando-os em seguida para fora d'água por meio de cordinhas de algodão ou de casca de árvores. (Thevet, 1978, p.95)

12 Encontram-se notas muito semelhantes, porém, menos detalhadas, na obra do jesuíta Francisco Soares (1966, p.153), escrita em 1591. 
[...] a respeito do modo de pescar dos Tupinambá, que além de flechas usam também espinhas a feição de anzóis, presas a linhas feitas de uma planta [...] a qual se desfia como cânhamo e é muito mais forte. Com esse apetrecho pescam de cima das ribanceiras e à margem dos rios. Também penetram no mar e nos rios com jangadas [...] são feitas de cinco ou seis paus redondos, mais grossos que o braço de um homem e bem amarrados com cipós retorcidos. (Léry, 1972, p.148-9)

Contudo, certa espécie de peixe, denominada pelos Tupinambá de "uaraua, maior e mais encorpado do que o maior boi" (Abbeville, 2002, p.235), mereceu inúmeros relatos e foi alvo de diversas especulações, seja pelo seu tamanho, seja por suas características atípicas se for comparada com os "peixes comuns". A partir disso, seguem as descrições do porte e do tipo de alimento que esse animal consome: "é esse peixe de tamanho imenso e alimenta-se de ervas como indicam as gramas mastigadas presas nas rochas banhadas por mangues”. Depois dessas observações iniciais, a analogia com o boi terrestre, já conhecido e domesticado pelo europeu, será uma constante na narrativa de Anchieta:

excede ao boi na corpulência [...] é coberto de uma pele dura, assemelhando-se na cor à do elefante; tem junto aos peitos como se fossem dois braços, com que nada, e embaixo deles tetas com que aleita os próprios filhos [...] tem a boca inteiramente semelhante à do boi [...] e é excelente para comer-se, não saberias porém discernir se deve ser considerado como carne ou antes como peixe. (Anchieta, 1988, p.117)

Prosseguindo com as referências ao já conhecido, o jesuíta concluiu sua explanação:

da sua gordura, que está inerente à pele, sobretudo em torno da cauda, levada ao fogo faz-se um molho, que pode bem comparar-se à manteiga, e não sei se a excederá [... o o seu óleo serve para temperar todas as comidas: todo o seu corpo é cheio de ossos sólidos e duríssimos, tais que podem fazer às vezes de marfim. (Ibid., p.118) 
Este mesmo animal também chamou a atenção de Gandavo que, ao descrevê-lo, apresentou elementos semelhantes à narrativa do religioso da Companhia de Jesus. Começou, assim como Anchieta, a tratar o animal pelo exotismo:

deixando à parte a muita variedade daqueles peixes que comumente não diferem na semelhança dos de cá, tratarei logo em especial de certo gênero deles que há nestas partes, a que chamam peixes-boi, os quais são tão grandes que os maiores pesam cinquenta arrobas.

Em sequência, considerou o peixe-boi uma espécie largamente distinta de qualquer outra que conheceu na Europa, mas, mesmo assim, não deixou de referenciar o boi conhecido pelo europeu: "tem o focinho como o de boi e duas palmas com que nadam à maneira de braços. As fêmeas têm duas tetas, com o leite das quais se criam os filhos". E continuando esta prática de dar um referencial ao novo através do já conhecido, concluiu que "não tem feição alguma de nenhum peixe, somente na pele quer se parecer com a toninha” (Gandavo, 1980, p.31). O francês Yves d'Evreux, enfim, além de corroborar os trechos supracitados, adicionou uma característica comportamental ao peixe-boi que é partilhada até os dias atuais, a saber, sua docilidade:

estes peixes tem a testa como os bois, porém sem cornos, duas patas adiante debaixo das mamas, parem os filhos como as vacas, nutrem-nos com seu leite, mas a cria tem a propriedade notável de abraçar a mãe pelas costas com suas patinhas, e nunca os deixa, embora mortas, pelo que alguns são agarrados vivos, e assim trazidos para a ilha: são muito delicados. (Evreux, 2002, p.153)

Outro animal, nos séculos XVI e XVII, igualmente classificado como peixe pelo líder dos capuchinhos na "ilha do Maranhão" foi a "onça marinha, tendo a parte anterior igual a da terra e a posterior semelhante a cauda de um peixe" (ibid., p.147). Acerca desta espécie, conclui-se que Evreux fazia menção à ariranha. Porém, nenhum outro animal encontrado nas terras sob domínio português causou 
maior admiração e espanto, simultaneamente, do que a preguiça, também conhecida como bicho-preguiça. Os colonizadores, perplexos diante dela, a descreviam como criatura com o corpo de animal e com a fronte humana: para Thevet (1978, p.169), a cara lembrava a de uma criança, no corpo apresentava pelugem curta e nas mãos unhas muito compridas, por sua vez, Abbeville foi mais categórico em sua observação inicial: "é animal monstruoso, de cabeça redonda, semelhante à do homem” (Abbeville, 2002, p.238).

Apesar dos animais exóticos pontualmente terem ganhado espaço nas narrativas de religiosos, viajantes e colonos, esses homens não deixaram de anotar suas impressões acerca da variedade animal presente nas matas e florestas brasileiras. $\mathrm{O}$ capuchinho que também participou da aventura colonizadora na França Equinocial, Louis de Pezieu, mais sintético e breve em suas cartas em comparação com seus confrades, redigiu:

as matas estão cheias de cervos e macacos, muito melhores do que os da França, e de diversos outros animais que não temos, com aparência totalmente distinta dos animais da Europa e com o sabor melhor do que o das lebres. (Pezieu apud França, 2012, p.219)

Em sua obra, Claude d'Abbeville (2002, p.224-49) formulou quatro capítulos para discorrer sobre a abundância da fauna tropical: um capítulo a propósito dos pássaros, um acerca dos peixes, um sobre os animais terrestres e outro sobre os insetos, os quais sinonimizou a "animais imperfeitos". Em suas páginas, onde se faz presente analogia direta entre "os de cá" e "os de lá", lê-se o seguinte trecho: "não temos entre nós todas as espécies de animais que eles têm, nem eles possuem nada que se assemelhe aos nossos, a não ser com grande diferença [... ] possuem entretanto muitos veados e javalis não inteiramente iguais aos nossos" (ibid., p.236). Entretanto, Yves d'Evreux, que escreveu depois de Abbeville, fez questão de elucidar que as suas observações a propósito da natureza foram registradas com a finalidade de completar as informações de seu confrade quando explicou que "somente acrescentarei o que mais do que ele soube por 
experiência, pois eu estive no Maranhão dois anos completos e ele apenas quatro meses" (Evreux, 2002, p.23). Dessa forma, por mais que o frade Abbeville tenha se dedicado a narrar suas impressões da fauna durante o curto período que viveu em solo maranhense, o valor do tempo e da experiência configuram um elemento central na obra do líder capuchinho na França Equinocial e também no período em que ele escreveu. ${ }^{13}$

Ainda em relação à variedade dos animais, outro elemento recorrente nos relatos daqueles que permaneceram ou somente estiveram de passagem pela colônia portuguesa na América foi o medo ${ }^{14}$ da fauna. O navegador francês Pierre Laval, que aportou no Brasil em 1610 e conheceu apenas a cidade de Salvador, pontuou: "a caça é muito pouco praticada, pois a região tem uma mata muito densa $e$ está repleta de animais ferozes, o que faz com que os brasileiros não ousem entrar nos bosques com medo de serem devorados" (Laval apud França, 2012, p.188). Ademais, a onça, nas palavras de Evreux, era o animal mais furioso do Brasil (Evreux, 2002, p.159). Dentre outros fatores, como a curiosidade e a expectativa, esse medo diante do desconhecido possibilitou tanto aos relatos de viagem quanto à mitologia ${ }^{15}$ alcançarem um papel fundamental no novo sistema colonial, permitindo que a intervenção do maravilhoso incidisse durante a experiência, movimentando-se entre a realidade e o mito, apropriando-se de ambos. Além disso, mais que se alinhar com uma ou com outro, o maravilhoso fundiu ambas as categorias, originando uma forma de narrar e absorver imagens (Giucci, 1992, p.14). Isto aconteceu porque uma nova realidade, sempre que é deparada, passa por um caminho interpretativo do diferente através do "si mesmo" e, por isso, considera-se que as representações acerca do Novo Mundo revelaram-se elemento da prática de representação dos europeus (Greenblatt, 1996, p.24) e que o maravilhoso elucidou mais sobre

13 Sobre o assunto, consultar Hartog (1999); Godinho (2008). Os autores, entre outras hipóteses, sugerem que a experiência se impõe ao saber livresco a partir do século XVI.

14 Sobre o assunto, consultar Teixeira (2004).

15 Sobre o assunto, consultar Eliade (1972). 
a ideologia que o engendra e consome do que sobre a realidade que declarou reproduzir (Giucci, 1992, p.16).

Os trechos abaixo, escritos por Léry, exemplificam a presença do maravilhoso nas narrativas coloniais, onde tanto os animais marinhos como os terrestres adquiriram proporções míticas:

Certa ocasião dois franceses e eu cometemos o erro de visitar o país sem guias selvagens e perdemo-nos na mata [...] ouvimos o rumor de um bruto que vinha em nossa direção, mas pensando que fosse algum selvagem, não paramos nem demos importância ao caso. De repente, a trinta passos de distância, à direita, vimos na encosta da montanha um enorme lagarto maior do que um homem e com comprimento de seis a sete pés. Parecia revestido de escamas esbranquiçadas, ásperas e escabrosas como casacas de ostras; ergueu uma pata dianteira e com a cabeça levantada e os olhos cintilantes, encarou-nos fixamente. Como nenhum de nós trazia arcabuz ou pistola, mas somente espadas, arcos e flechas na mão, armas inúteis contra animal tão bem armado, ficamos quietos e imóveis, pois temíamos que, fugindo, o bruto viesse contra nós e nos devorasse. O monstruoso lagarto [...] fugiu morro acima fazendo mais barulho nas folhas e ramos do que um veado correndo na floresta [...] dizem que o lagarto se deleita ao aspecto do rosto humano, e é certo que esse teve tanto prazer em olhar para nós quanto nós tivemos pavor em contemplá-lo.

$[\ldots]$

Ouvi de um dos selvagens um episódio de pesca [...] disse-me ele que, estando certa vez com outros em uma de suas canoas de pau, por tempo calmo em alto-mar, surgiu um grande peixe que segurou a embarcação com as garras. Vendo isso, continuou o selvagem: "decepei-lhe a mão com uma foice, a mão caiu dentro do barco e vimos que ela tinha cinco dedos como a de um homem. E o monstro, excitado pela dor, pôs a cabeça fora d'água e a cabeça, que era de forma humana, soltou um pequeno gemido". Resolva o leitor sobre se se tratava de um tritão, de uma sereia ou de um bugio-marinho, atendendo a opinião de certos autores que admitem existirem no mar 
todas as espécies de animais terrestres. Quanto a mim, embora não desminta a existência de tais coisas [...] nada vi semelhante. (Léry, 1972, p.128-129, 147-148)

Além dos indícios da combinação entre mito e realidade, o que se faz digno de nota nas passagens acima citadas é a forma que o viajante francês se coloca diante de duas situações um tanto quanto similares. No primeiro fragmento, sobre o "monstruoso lagarto", ele se colocou como personagem principal do enredo e destacou que, juntamente com mais dois franceses, "viram" a criatura e temeram ser devorados. Depois disso, para encerrar o tema e dar credibilidade à sua descrição, pontuou que os indígenas "dizem" que esse animal apenas gosta de olhar as faces humanas, motivo pelo qual foram encarados por ele. Já no segundo trecho, percebe-se que Léry não presenciou a situação relatada pelos nativos e, por isso, mesmo considerando a possibilidade de existirem criaturas antropozoomórficas, como sereias e tritões, ${ }^{16}$ deixa para os seus leitores o exercício de validar, ou não, o que foi escrito. Dessa maneira, uma vez mais pode-se considerar a importância da experiência, agora aliada ao maravilhoso, no período e espaço coloniais.

Para elucidar a força adquirida por esses mitos desde os primeiros séculos da colonização, estão presentes nas páginas de Evreux duas histórias que ainda repercutem e encontram ouvintes crédulos entre a população amazônica contemporânea. Depois de descrever algumas características físicas de certa espécie de macacos "grandes, fortes, barbados e de sexo bem distinto” (Evreux, 2002, p.168), prosseguiu afirmando que esses primatas respondiam a todo ataque humano com similar violência, lançando objetos pontiagudos com pontaria certeira em seus agressores e que eles, se quisessem, tinham perfeitas condições de manter relações sexuais com as mulheres (Ibid., p.168-9). Acerca desta última constatação, redigida pelo capuchinho, que possui elementos comuns aos mitos amazônicos do boto e do vento, sua permanência no imaginário popular acaba, em última

16 Sobre o assunto, consultar Taunay (1999); Holanda (1969). 
instância, servindo como desculpa, socialmente aceitável, para aventuras socialmente condenáveis. ${ }^{17}$

Em suma, depois de apresentados todos os fragmentos documentais supracitados, percebe-se a permanência dessas impressões positivas acerca da natureza brasileira até a atualidade, tanto no Brasil quanto no exterior. Inauguradas em Vespúcio e partilhadas pelos viajantes, clérigos e colonos posteriores a ele, essas imagens, a saber, o clima ameno, a fertilidade do solo, a exuberância da flora e a variedade da fauna consolidaram-se de tal maneira que ainda ganham respaldo nos discursos sobre o Brasil.

Entretanto, esses mesmos colonizadores não deixaram de considerar suas impressões negativas em relação a esses quatro pilares que compunham os biomas brasílicos. As visões pejorativas da fauna, por exemplo, começaram brandas e pontuais em suas cartas e obras: Abbeville, mais uma vez utilizando a comparação como recurso linguístico, dissertou sobre os andirás, "morcegos muito parecidos com os nossos, porém, maiores e que gritam muito mais alto e de um modo horrível” (Abbeville, 2002, p.189). O animal que também atraiu os olhares dos religiosos que estiveram na França Equinocial foi o "papa-formigas" que, para Evreux, não passava de "certa espécie de cão selvagem com pelo de lobo, fedorento o mais que é possível, focinho e língua muito aguda, e que procura o formigueiro para alimentar-se" (Evreux, 2002, p.165). Além disso, os tamanduás aparecem relacionados com outro animal amplamente observado e que também ganhou péssima fama: a formiga. Abbeville escreveu que eram espécies tão repulsivas que os índios guerreiros recusavam-se a caçar o "papa-formigas", "alegando que, se comerem a carne deste animal que se alimenta de formigas, ficariam débeis e sem coragem na guerra" (Abbeville, 2002, p.192).

O padre Ambrósio Pires, em 1555, prenunciou um tema de discussão que muito interessaria a outros relatores coloniais, a saber, os hábitos e as ações dos "animais nocivos". As formigas, em diversas passagens, aparecem como espécie danosa:

17 Sobre o assunto, consultar Simões (1989). 
Há aqui infinito número de formigas, que tem na boca umas serras como tenazes, com as quais devastam todo o plantio e, o que é pior, o faz murchar [...] e assim os lavradores lhes dão comida para que não estraguem a tudo com o veneno das bocas e nem façam secar as plantas de cuja raiz fazem o pão: principalmente porque dão cabo em uma noite do que custa muitos dias a muitos homens, coisas que só se acredita vendo [...] não se faz uma horta que não fique logo perdida. (Pires, 1988, p.141)

Gabriel Soares de Sousa, complementando esta visão negativa, pontuou que

são tantas essas formigas, quando passam, que não há fogo que baste para queimá-las, e põem em passar por um lugar toda uma noite, e se entram de dia, todo um dia [...] as quais vão andando em ala de mil em cada fileira; e se as casas em que entram são térreas, e acham a roupa da cama no chão, por onde elas subam, fazem levantar muito depressa a quem nela jaz, e andar por cima das caixas e cadeiras, sapateando, lançando-as fora e coçando [...] porque elas, quando chegam, cobrem uma pessoa toda, e se acham cachorros e gatos dormindo, dão neles de jeito, e em outros animais, que os fazem voar. (Sousa, 1971, p.270)

Outros artrópodes considerados lesivos em suas ações por apresentar, assim como as formigas, peçonha e veneno foram as aranhas. Apesar de não viverem em bandos nem serem prejudiciais às plantações, receberam atenção porque muitas espécies eram muito grandes e suas mordeduras causavam dor. Soares de Sousa dissertou sobre a nhanduçu, que em tupi significa "aranha grande", a qual conhecemos hoje como caranguejeira e que o colono português explicou a razão de tal alcunha:

$\mathrm{Na}$ Bahia se cria muita diversidade de aranhas, e tão estranhas que convém declarar a natureza de algumas. E peguemos logo as que chamam nhanduçu, as quais são tamanhas como grandes caranguejos, e 
muito cabeludas e peçonhentas $[\ldots]$ remetem à gente de salto, e têm os dentes tamanhos como ratos, cujas mordeduras são muito perigosas [...] e criam-se em paus podres, no côncavo deles, e no povoado em paredes velhas. (Ibid., p.268)

Por sua vez, o jesuíta António Pires, três anos após a chegada de seus correligionários à América portuguesa, expôs uma concepção pejorativa do solo ao apresentar a tópica da natureza sob outro viés: o da terra encoberta pela problemática da moralidade, assunto que em muito preocupou os inacianos. Assim,

essa capitania é terra de muito tráfico e outros pecados, que é com força de virtude que se acabarão e não com meu exemplo. Já agora dizem que se vão tirando e eu tenho ouvido dizer de homens que têm os olhos alguns tanto abertos, que depois que a ela viemos, das dez partes dos pecados que nela havia, as oitos são fora. E assim havia quatro ou cinco anos não chovia nela, e este ano choveu tanto e recolheram tanto mantimento que é pasmo, e já os da terra se vão persuadindo que por causa dos pecados não chovia: louvam muito a Deus. Por aqui vereis, irmãos, quanta necessidade essa terra tem de nossas contínuas orações. (Pires, 1988, p.123)

Nesta passagem, Pires relacionou diretamente a péssima condição climática e, em consequência dela, a improdutividade do solo aos incessantes pecados praticados tanto pelos colonizadores quanto pelos naturais da terra. Também consta nas anotações de Abbeville uma sutil observação que contradiz a ideia de que tudo o que os indígenas plantavam no Brasil era colhido sem grandes esforços: "a mandioca e a batata com que se alimentam se comprazem em terras novas e produzem mais" (Abbreville, 2002, p.221). Portanto, depois de observar essas explanações, compreende-se que a terra não perdeu completamente suas características pródigas, mas alternavam-se relatos que corroboravam, ponderavam e até mesmo, apesar de poucos, negavam essa positiva concepção. Boa parte dessas anotações que desqualificavam o mundo natural está intensamente atrelada à ideia da 
presença do demônio no novo espaço colonial, ${ }^{18}$ defendida tanto por religiosos quanto por leigos. Ao se referir à jararaca e suas aptidões letais, Anchieta ajuizou que

a sua mordedura mata no espaço de 24 horas, posto que se lhe possa aplicar remédio e evitar algumas vezes a morte. Isto acontece com certeza entre os índios: se forem mordidos uma só vez escapam da morte, mordidos daí em diante, não só não correm risco de vida, como sentem até menos dor. (Anchieta, 1988, p.121)

Neste trecho, o jesuíta confere contornos demonizados tanto aos nativos quanto ao ofídio, uma vez que os indígenas, por não conhecerem a palavra de Deus, pouco sentem a ação do veneno de animal tão pernicioso. Prosseguindo com suas anotações, Anchieta cita o episódio do paraíso em que Eva comeu a maçã depois de ser seduzida pelo diabo, em forma de serpente, e legou à humanidade sua condição mortal e pecadora (ibid., 121-2). Aliás, nas palavras do frei Vicente do Salvador, Lúcifer se fez presente desde o descobrimento e primórdios da colonização da América portuguesa:

O dia em que o capitão-mor Pedro Álvares Cabral levantou a cruz [...] era três de maio, quando se celebra a invenção da Santa Cruz, em que Cristo Nosso Redentor morreu por nós, e por esta causa pôs nome à terra que havia descoberta de Santa Cruz e por este nome foi conhecida muitos anos, porém, como o demônio com o sinal da cruz perdeu todo o domínio que tinha sobre os homens, receando perder também o muito que tinha nos desta terra, trabalhou que se esquecesse o primeiro nome e lhe ficasse o de Brasil, por causa de um pau assim chamado, de cor abrasada e vermelha, com que tingem panos, que o daquele divino pau que deu tinta e virtude a todos os sacramentos da Igreja. (Salvador, 1975, p.28)

18 Sobre o assunto, consultar Souza $(2009,2011)$. 
Assim, depois de apresentar e analisar o corpus documental supracitado, compreende-se que esses colonos, viajantes e religiosos buscaram em suas narrativas, inclusive nos fragmentos que aludem ao maravilhoso e à demonização, comunicar todo o conhecimento que conseguiram apreender acerca dos usos práticos do solo, da flora e da fauna, pontuando as suas potencialidades medicinais como também os riscos existentes no consumo ou no ataque daqueles que possuíam veneno em seu interior ou em suas peçonhas. Logo, percebe-se que esses homens empenharam-se em descrever, recorrendo, na maioria das vezes, à comparação, as peculiaridades de cada espécie com a qual tinham contato. Ademais, os feitos, tanto dos portugueses quanto dos franceses, para tornar viável sua permanência e a exploração do Brasil durante os primeiros séculos da colonização, se constituíram mais complexos que a elucidação simplista, largamente partilhada, da coleta de pau-brasil e, posteriormente, do cultivo da monocultura açucareira na região Nordeste. Através da classificação dos biomas locais, esses europeus observaram e estudaram meticulosamente o novo ambiente em que estavam inseridos e esse conhecimento acerca da natureza e de seus recursos, em última análise, facilitou a experiência colonizadora na América portuguesa. E, inseridos na natureza, os habitantes da jovem colônia também ganharam relevância na produção textual do período.

\section{Idealização e degeneração dos nativos}

Na primeira carta portuguesa acerca da então Terra de Vera Cruz e seus habitantes, escrita por Pero Vaz de Caminha, ${ }^{19}$ percebe-se uma

19 As duas outras missivas que dissertam sobre a chegada de Pedro Álvares Cabral ao Brasil são A carta de Mestre João Faras e a Relação do Piloto Anônimo. João Faras, por ser astrônomo, preocupou-se com a identificação de algumas estrelas e nada escreveu em relação à terra ou acerca de seus habitantes. Já o Piloto Anônimo, apesar de apresentar, na parte referente ao Brasil, informações sem os detalhes que encontramos no texto caminiano, corroborou algumas informações apresentadas na carta de Caminha sobre a riqueza geográfica da terra, os bons 
gradual "descoberta" dos homens e, com isso, concebe-se também que, desde o início, nunca houve dúvida sobre a humanidade dessa nova alteridade: "homens pardos, todos nus, sem nenhuma coisa que lhes cobrisse suas vergonhas, traziam arcos nas mãos e suas setas" (Caminha, 1968, p.21). Além disso, essa representação da nudez se relacionou à ideia de inocência. Quando escreveu acerca das mulheres, Caminha ressaltou que "suas vergonhas tão altas, tão cerradinhas e tão limpas de cabeleiras que, de a nós muito bem olharmos, não tínhamos nenhuma vergonha" (ibid., p.36-7). Em seguida, ao realizar sua primeira comparação, utilizou como exemplo uma índia que possuía "sua vergonha tão graciosa, que a muitas mulheres da nossa terra, vendo-lhes tais feições, fizera vergonha, por não terem a sua como ela" (ibid., p.40). Nesse sentido, a ideia de que esses homens não idolatravam coisa alguma, tanto no plano material quanto no plano espiritual, é tão forte em Caminha que ele acabou por iniciar duradouras e duvidosas imagens, pois, para ele, esses homens eram todos como uma folha em branco "e imprimir-se-á com a ligeireza neles qualquer cunho, que lhes quiseram dar” (ibid., p.80) por não conhecerem a imortalidade da alma. ${ }^{20}$

Todavia, como vimos, foram as cartas de Américo Vespúcio que tornaram notável a Terra de Santa Cruz. Juntamente com o relato de Caminha, suas missivas completaram o conjunto de representações que se tinha, até então, sobre os índios. ${ }^{21}$ Além disso, foi o florentino que descreveu pela primeira vez, de maneira paradoxal, a antropofagia indígena: tinham tudo em comum entre si, contudo, de maneira

ares e temperatura agradável, o aspecto físico dos índios e suas moradias, além da exuberância e variedade da natureza. Por fim, pontuou a relação amistosa entre os lusos e os indígenas, destacando a boa maneira com que os nativos receberam e trataram os degredados na partida das naus. Cf. Pereira (1999).

20 Entretanto, os jesuítas, visando a conversão dos nativos, se apoiarão sobre as crenças indígenas a fim de mesclá-las aos hábitos religiosos cristãos e, desta maneira, os padres da Companhia de Jesus contrariaram o relato de Caminha.

21 O termo "índios", utilizado aqui, foi empregado de maneira anacrônica, pois nos relatos de Caminha eVespúcio encontramos as palavras "gente", "homens" e "mulheres". Os vocábulos "índio", "gentio", "Brasil” e "brasileiro" serão empregados a partir de meados do século XVI. 
cruel, não deixavam de guerrear com seus inimigos e de perpetuar suas atividades guerreiras. Os fundamentos dessa guerra incessante, para Vespúcio, se apresentaram obscuros, porém, ele indicou que os nativos faziam isso para vingar a morte de seus antepassados e parentes (Vespúcio, 2003, p.62). Dessa forma, se iniciou a disseminação dos pensamentos, que permaneceram por muito tempo em voga, acerca de uma guerra desinteressada e sobre uma antropofagia vingativa entre os brasis.

Vespúcio, também pela primeira vez, foi o viajante que escreveu as primeiras linhas referentes à longevidade dos habitantes do Novo Mundo e suas relações com os elementos da natureza associados ao cosmos:

são pessoas que vivem muitos anos, porque, segundo suas descendências, conhecemos muitos homens que têm até a quarta geração de netos. Não sabem contar os dias, nem o ano, nem os meses, salvo que medem o tempo por meses lunares, e quando querem mostrar a idade de alguma coisa o mostram com pedras, colocando por cada lua uma pedra, e encontrei um homem dos mais velhos que me mostrou com pedras ter vivido 1700 luas, que me parece ser 130 anos, contando treze luas por ano. (Ibid., p.81)

Graças a esses dois viajantes, formou-se a imagem dos habitantes da América portuguesa que perdurou até o fim da década de 1540 . Assim, em obra datada de 1519, o italiano Antonio Pigafetta apresentou todas as informações acima pontuadas de maneira condensada: homens e mulheres andavam nus, costumavam viver até os 140 anos, não eram cristãos, contudo, não idolatravam coisa alguma e devoravam seus inimigos (Pigafetta, 1985, p.102-7).

Devido à chegada dos jesuítas em 1549 e aos constantes intercâmbios costeiros entre índios e viajantes de outros reinos que não o português, a partir da década de 1550, o conhecimento e as informações acerca do Brasil tornaram-se mais precisos e, nesse contexto de interação, encontram-se dois viajantes que viveram entre os Tupinambá: o aventureiro alemão Hans Staden, que passou pelo convívio como 
inimigo a ser devorado, os descreveu como pessoas inteligentes e astutas (Staden, 1974, p.192), e Jean de Léry, que conviveu com os nativos na situação de aliado. O calvinista, que por quase um ano viveu em terra na companhia de outros franceses e dos nativos, empenhou-se, corroborando com as iniciais anotações de Caminha, em esclarecer aos seus coetâneos que os índios não apresentavam grandes diferenças físicas em relação aos europeus: "não são maiores nem mais gordos", mas eram "mais fortes, mais robustos, mais entroncados, mais bem dispostos e menos sujeitos à moléstia”, características que, segundo ele, decorriam do modo de vida despreocupado dos nativos e, confirmando as primeiras impressões de Vespúcio acerca da natureza e da longevidade dos habitantes do Brasil, do

bom clima da terra, sem geadas nem frios excessivos que perturbam o verdejar permanente dos campos e da vegetação [...] apesar de muitos chegarem aos 120 anos, poucos são os que na velhice têm cabelos brancos ou grisalhos, o que demonstra não só o bom clima da terra [...] mas ainda que pouco se preocupam com as coisas desse mundo. (Léry, 1972, p.101-2, 111)

Aliada à ausência de bens e cobiça entre os nativos, essa indiferença com as materialidades mundanas foi uma das características que cada vez mais ganhou evidência no período, dessa forma, Léry (1972, p.179), um dos principais disseminadores dessa ideia, criticou severamente a sociedade francesa que, em suas palavras, era impulsionada somente pelas relações comerciais e pelo lucro. Além do huguenote, Soares de Sousa apontou que:

têm esses tupinambás uma condição muito boa para frades franciscanos, porque o seu fato, e quanto têm, é comum a todos os da sua casa que querem usar dele [...] assim das ferramentas que é o que mais estimam, como das suas roupas se as têm, e do seu mantimento, os quais, quando estão comendo, pode comer com eles quem quiser, ainda que seja contrário, sem o impedirem nem fazerem por isso carranca. (Sousa, 1971, p.313) 
Ao analisar essa passagem, percebe-se que os índios da costa interessavam-se por bens materiais, tanto que o comércio com o europeu se baseou nesse desejo, contudo, eles meramente não os acumulavam. E foi essa virtude que levou os viajantes, os colonizadores e os religiosos a atender a continuidade e a regeneração de sua própria existência, além de, e sobretudo, suas próprias tradições sociais e culturais. Esses homens transformaram a viagem ao Novo Mundo em um ciclo e os textos produziram um retorno, de si para si, pela mediação do outro, ${ }^{22}$ uma vez que as comparações e analogias foram os mecanismos mais utilizados por esses europeus para descrever tanto os habitantes quanto a natureza do Novo Mundo, e essa prática funcionou como um espelho, que não reflete a imagem tal qual ela é, mas reflete a imagem invertida. Sendo a inversão uma maneira de transcrever a alteridade, os viajantes não enxergaram o índio como um humano completamente antagônico a eles; antes disso, viram o nativo e suas práticas culturais como a inversão do europeu e de sua cultura (Hartog, 1999, p.230-1). Léry sintetiza essas ideias ao explicitar que

esse país da América, como deduzirá quem o vir, no que diz respeito ao modo de vida de seus habitantes, à forma dos animais e, em geral, ao que a terra produz, é tão dessemelhante em vista do que temos na Europa, na Ásia e na África, que pode bem ser chamado de mundo novo com relação a nós. (Léry, 1972, p.28)

Outra representação amplamente difundida nos países colonizadores foi a possível falta de valores políticos e religiosos entre os tupis. Gandavo, de maneira singular, foi o precursor desta ideia ao relatar que "a língua deste gentio toda pela costa é uma: carece de três letras, não se acha nela F, nem L, nem R, coisa digna de espanto, porque assim não tem Fé, nem Lei, nem Rei; e desta maneira vivem

22 Cf. Certeau (1982. p.215). Sobre a busca e a formação da identidade dos portugueses diante do "outro", consultar Costa e Lacerda (2007); Azevedo (1999); Massimi (1995). 
sem justiça e desordenadamente" (Gândavo, 1980, p.52). Esse preceito também foi partilhado por Thevet quando lemos suas impressões acerca dos

estranhíssimos povos selvagens, sem fé, lei, ou religião e nem civilização alguma, vivendo antes como animais irracionais, assim como os fez a natureza, alimentando-se de raízes, andando sempre nus tanto os homens quanto as mulheres, à espera do dia em que o contato com os cristãos lhes extirpe esta brutalidade, para que eles passem a vestir-se, adotando um procedimento civilizado e humano. (Thevet, 1978, p.98)

Soares de Souza, dezessete anos depois, retomou de forma mais detalhada a regra sugerida por Gandavo e escreveu:

Faltam-lhes três letras das do ABC, que são F, L, R grande ou dobrado, coisa muito para se notar [...] porque, se não têm $\mathrm{F}$, é porque não têm fé em nenhuma coisa que adorem; nem nascidos entre os cristãos e doutrinados pelos padres da Companhia têm féem Deus Nosso Senhor, nem têm verdade, nem lealdade e nenhuma pessoa que lhes faça bem. E se não tem L na sua pronunciação, é porque não têm lei alguma que guardar, nem preceitos para se governarem; e cada um faz lei a seu modo, e ao som da sua vontade; sem haver entre eles leis com que se governem, nem têm leis uns com os outros. E se não têm esta letra $R$ na sua pronunciação, é porque não têm rei que os reja, e a quem obedeçam, nem obedecem a ninguém, nem ao pai o filho, nem o filho ao pai. (Sousa, 1971, p.302)

Essa carência política e religiosa, apesar de ter sido carregada de valores pejorativos, principalmente na obra de Thevet, refletiu de maneira paradoxal entre os europeus: ora eles acreditavam que o Brasil era o Éden, ora supunham que era a barbárie. Contudo, na França, onde os normandos prosperavam com os lucros do pau-brasil, via escambo com os Tupinambá, essa ausência de letras e valores não inquietava, pois as relações comerciais os fazia prosperar. 
Já o canibalismo, durante todo o século XVI e início do século XVII, foi entendido como uma forma de "assombração", e isso se deve ao fato dele ser uma das representações que integraram, por muito tempo, de maneira assustadora, o imaginário medieval. ${ }^{23}$ Entretanto, o que permitiu a redenção dos nativos brasileiros foi a distinção entre canibais e antropófagos. ${ }^{24}$ Os tupis, exceto em alguns relatos, como os de Thevet, ${ }^{25}$ não foram encarados como cruéis canibais, como gente que se alimentava de carne humana; a diferenciação residiu no fato de que eles comiam seus inimigos por vingança, o que foi apontado tanto por Staden, quando lemos que os Tupinambá "fazem isto, não para matar a fome, mas por hostilidade, por grande ódio” (Staden, 1974, p.176), quanto por Léry:

Mas não comem a carne, como poderíamos pensar, por simples gulodice [...] seu principal intuito é causar temor aos vivos. Move-os a vingança $[. .$.$] para satisfazer seu sentimento de ódio, devoram$ tudo do prisioneiro, desde os dedos dos pés até o nariz e cabeça, com exceção dos miolos, em que não tocam. (Léry, 1972, p.180)

Comum a esses viajantes foi a compreensão de que a antropofagia constituía o principal vínculo que unia os índios da costa brasileira, porquanto, era ao matar o inimigo que o guerreiro recebia nomes novos, adquiria prestígio social e político, estava apto para o casamento e, imediatamente, tornava-se imortal. Todas as pessoas, inclusive os aliados das outras aldeias, deviam se alimentar da carne do morto, com exceção do guerreiro que tirou a vida de sua vítima. ${ }^{26}$

23 Sobre o assunto, consultar Le Goff (1994).

24 Sobre o assunto, consultar Agnolin (2005) e Bandeira (2006).

25 "Ao estabelecer contato com um dos nativos, o indagou a respeito da crueldade do canibalismo e teve como resposta que ele e todos os franceses é que deveriam se envergonhar de perdoar os prisioneiros de guerra e que a melhor atitude a ser tomada seria os matar, não fornecendo a eles oportunidade de iniciar outra guerra. Este diálogo levou o franciscano a concluir que este era 'o modo de pensar desse povo ignorante"” (Thevet, 1978, p.127).

26 Sobre o assunto, consultar Viveiros de Castro (1986); Fernandes (1963). 
Desta maneira, compreende-se que a guerra e a antropofagia foram as instituições fundamentais das sociedades tupis do período e, graças a essa diferenciação elaborada pelos colonizadores, entre canibais e antropófagos, que os índios do Brasil se tornaram o "peso na consciência" das civilizações europeias, pois eles viviam em uma sociedade onde a igualdade e a concórdia eram latentes, onde não havia distinção entre o que "é meu" e o que "é seu", não acumulavam riquezas e as guerras intermináveis eram louváveis por não serem impulsionadas pelo lucro ou pela aquisição de territórios.

Porém, ao exaltarem as qualidades desses antropófagos, os viajantes não construíram discursos histórico-etnográficos, mas sim apresentaram alocuções carregadas de valores morais e, com isso, acabaram por estabelecer o início de uma duradoura imagem: o natural da terra como testemunha de acusação de uma civilização corrupta e atroz. Encontramos essa representação em toda a obra de Léry, na qual o "selvagem" está posicionado de maneira opositora e positiva em relação a todas as injustiças sociais sobre as quais o autor teceu suas denúncias. Pois, diante da barbárie causada pelas guerras de religião na Europa - entre católicos e protestantes - e, principalmente, na França, durante a segunda metade do século XVI, as características sociais dos tupis foram vistas como a maneira mais civilizada dentro desse contexto de crueldades. Em contraponto a essa exaltação, Nóbrega principiou outra imagem acerca dos indígenas brasileiros que, também por muito tempo, perdurou, a saber, a inconstância de suas almas e, por isso, de suas ações:

sabeis qual é a maior dificuldade que lhes acho? Serem tão fáceis de dizer a tudo aani ou pâ, ou como vós quiserdes; tudo aprovam logo, e com a mesma facilidade com que dizem $p \hat{a}$ ( $\operatorname{sim}$ ), dizem aani (não) [...] com um anzol que lhes dou, os converterei a todos, com outros os tornarei a desconverter, por serem inconstantes, e não lhes entrar a verdadeira fé no coração. (Nobrega, 2009, p.3, 5)

Por fim, ao analisarmos as primeiras impressões dos europeus diante dos nativos ao longo do Quinhentos e início do Seiscentos, é 
notável que elas passaram por consideráveis transformações, uma vez que na primeira década da colonização Caminha e Vespúcio viram homens e mulheres em Vera Cruz. Em sequência, o escambo povoou a terra de brasileiros e os engenhos distinguiram o gentio indócil do índio e do negro da terra que trabalhavam. Já os franceses, que não conseguiram se estabelecer no território, viram selvagens. Assim, depois de pontuar e problematizar todas essas questões, podemos considerar que, acerca das primeiras impressões sobre a natureza do Brasil, houve uma alternância nos relatos daqueles que estavam a serviço das coroas portuguesa e francesa, pois em todos os documentos analisados, seus autores por vezes exaltaram suas prodigalidades da mesma maneira que ressaltaram seus perigos e imperfeições. E esses mesmos documentos indicam que, tanto portugueses quanto franceses, assim como alguns viajantes de outros reinos, como Pigafetta e Staden, concederam aos habitantes da costa brasileira características nobres ao mesmo tempo que se referiam a eles de modo depreciativo e infame.

\section{Referências bibliográficas}

\section{Documentos}

ABBEVILLE, C. d'. História da missão dos padres capuchinhos na Ilha do Maranhão e suas circunvizinhanças. São Paulo: Editora Siciliano, 2002.

ANCHIETA, J. de. Cartas, informações, fragmentos históricos e sermões. Belo Horizonte: Itatiaia; São Paulo: Edusp, 1988.

CAMINHA, P. V. de. Carta a El Rey Dom Manuel. Rio de Janeiro: Sabiá, 1968. CARDIM, F. Tratados da terra e gente do Brasil. São Paulo: Editora Nacional; Brasília: Instituto Nacional do Livro, 1978.

EVREUX, Y. d'. Viajem ao norte do Brasil feita nos anos de 1613 e 1614. São Paulo: Editora Siciliano, 2002.

FRANÇA, J. M. C. (Org.). Outras visões do Rio de Janeiro colonial. Rio de Janeiro: José Olympio, 2000. Visões do Rio de Janeiro colonial. Rio de Janeiro: José Olympio, 1999.

GANDAVO, P. de M. Tratado da terra do Brasil; História da Província de Santa Cruz. Belo Horizonte: Itatiaia; São Paulo: Edusp, 1980. 
LEITE, S. (Org.). Cartas dos primeiros jesuítas do Brasil. São Paulo: Comissão do IV Centenário da Cidade de São Paulo, 1954. v.1-3.

História da Companhia de Jesus no Brasil. Belo Horizonte: Itatiaia, 2000. v.1-5.

LÉRY, J. de. Viagem à terra do Brasil. São Paulo: Martins/Edusp, 1972.

NAVARRO, A. et al. Cartas avulsas (1550-1568). Belo Horizonte: Itatiaia, 1988.

NÓBREGA, M. da. Dialago sobre a conversão do gentio. Disponível em: $<$ http:// www.ibiblio.org/ml/libri/n/NobregaM_ConversaoGentio_p.pdf $>$. Acesso em: 5/4/2011.

Carta do padre Manuel da Nóbrega. In: LEITE, S. (Org.). Cartas dos primeiros jesuítas do Brasil. São Paulo: Comissão do IV Centenário da Cidade de São Paulo, 1954. v.2.

PEREIRA, P. R. D. (Org.). Os três únicos testemunhos do descobrimento do Brasil. Rio de Janeiro: Lacerda Editores, 1999.

PIGAFETTA, A. A primeira viagem ao redor do mundo: o diário da expedição de Fernão de Magalhães. Porto Alegre: L\&PM, 1985.

PIRES, A. Carta do Padre António Pires de Pernambuco de 5 de junho de 1552. In: NAVARRO, A. et al. Cartas avulsas (1550-1568). Belo Horizonte: Itatiaia, 1988.

SALVADOR, V. do. História do Brasil: 1500-1627. São Paulo: Melhoramentos, 1975.

SOARES, F. Coisas notáveis do Brasil. Rio de Janeiro: Instituto Nacional do Livro/MEC, 1966.

SOUSA, G. S. de. Tratado descritivo do Brasil em 1587. São Paulo: Companhia Editora Nacional/Edusp, 1971.

STADEN, H. Duas viagens ao Brasil. Belo Horizonte: Itatiaia; São Paulo: Edusp, 1974.

THEVET, A. As singularidades da França Antarctica: a que outros chamam de America. Belo Horizonte: Itatiaia; São Paulo: Edusp, 1978.

VESPÚCIO, A. Novo Mundo: as cartas que batizaram a América. São Paulo: Planeta, 2003. 


\section{Estudos}

AGNOLIN, A. O apetite da Antropologia: o sabor antropofágico do saber antropológico. Alteridade e identidade no caso tupinambá. São Paulo: Associação Editorial Humanitas, 2005.

AZEVEDO, A. M. de. O índio brasileiro: o olhar quinhentista e seiscentista. In: CRISTÓVÃO, F. (Org.). Condicionantes culturais da literatura de viagens: estudos e bibliografias. Lisboa: Edições Cosmos; CLEPUL, 1999.

BANDEIRA, J. Canibais no paraíso: a França Antártica e o imaginário europeu quinhentista. Rio de Janeiro: Mar de Ideias, 2006.

CARDOSO, A.; OLIVEIRA, A. B. de; MARQUES, M. S. (Coords.). Arte médica e imagem do corpo: de Hipócrates ao final do século XVIII. Lisboa: Biblioteca Nacional de Portugal, 2010.

CARNEIRO, H. S. Filtros, mezinhas e triacas: as drogas no mundo moderno. São Paulo: Xamã, 1994.

CERTEAU, M. de. A escrita da História. Rio de Janeiro: Forense Universitária, 1982.

COSTA, J. P. O.; LACERDA, T. A interculturalidade na expansão portuguesa: séculos XV-XVIII. Lisboa: Alto Comissariado para a Imigração e Minorias Étnicas, 2007.

CUNHA, M. C. da. Imagens de índios do Brasil: o século XVI. Estudos Avançados, São Paulo, Edusp, v.4, n.10, 1990.

ELIADE, M. Mito e realidade. São Paulo: Perspectiva, 1972.

FERNANDES, F. A organização social dos Tupinambá. São Paulo: Difusão Europeia do Livro, 1963.

FLECK, E. C. D. As curas de Deus e da Natureza. Revista de História, Rio de Janeiro, Fundação Biblioteca Nacional, v.59, 2010.

Sobre licores e xaropes: práticas curativas e experimentalismos jesuíticos nas reduções da Província Jesuítica do Paraguai: séculos XVII e XVIII. In: KURY, L.; GESTEIRA, H. (Orgs.). Ensaios de história das ciências: das Luzes à nação independente. Rio de Janeiro: Editora da Uerj, 2012.

FOUCAULT, M. As palavras e as coisas: uma arqueologia das ciências humanas. São Paulo: Martins Fontes, 1999.

FRANÇA, J. M. C. A construção do Brasil na literatura de viagem dos séculos XVI, XVII e XVIII. Rio de Janeiro: José Olympio; São Paulo: Editora Unesp, 2012.

O mundo natural e o erotismo das gentes no Brasil Colônia: a perspectiva do estrangeiro. Topoi, Rio de Janeiro, PPGH-UFRJ, v.11, n.20, 
2010. Disponível em: <http://www.revistatopoi.org/numeros_anteriores/ topoi20/topoi20_02artigo2.pdf>. Acesso em: 2/12/2011.

GINZBURG, C. A micro-história e outros ensaios. Lisboa: Difel, 1991.

GIUCCI, G. Viajantes do maravilhoso: o Novo Mundo. São Paulo: Editora Schwarcz, 1992.

GODINHO, V. M. A expansão quatrocentista portuguesa. Lisboa: Dom Quixote, 2008.

GRÃ, L. da. Carta do padre Luís da Grã ao padre João Gonçalves. In: LEITE, S. Cartas dos primeiros jesuítas do Brasil. São Paulo: Comissão do IV Centenário da cidade de São Paulo, 1954. v.2.

GREENBLATT, S. Possessões maravilhosas: o deslumbramento do Novo Mundo. São Paulo: Edusp, 1996.

HARTOG, F. O espelho de Heródoto: ensaio sobre a representação do outro. Belo Horizonte: Editora da UFMG, 1999.

HOLANDA, S. B. de. Visão do paraíso: os motivos edênicos no descobrimento e colonização do Brasil. São Paulo: Brasiliense, 1969.

LE GOFF, J. O imaginário medieval. Lisboa: Estampa, 1994.

MASSIMI, M. Visões do homem e aspectos psicológicos no encontro entre a cultura portuguesa e as culturas indígenas do Brasil no século XVI. In: ALFONSO-GOLDFARB, A. M.; MAIA, C. (Orgs.). História da ciência: o mapa do conhecimento. São Paulo: Edusp; Rio de Janeiro: Expressão e Cultura, 1995.

O' GORMAN, E. A invenção da América: reflexão a respeito da estrutura histórica do Novo Mundo e do sentido do seu devir. São Paulo: Editora Unesp, 1992.

PIRES, F. D. de A. Mamíferos da França Equinocial: Maranhão, Brasil. Revista Brasileira de Zoologia, Curitiba, Sociedade Brasileira de Zoologia, v.6, n.3, 1989.

RANDLES, W. G. L. Da Terra Plana ao Globo Terrestre: uma mutação epistemológica rápida (1480-1520). Campinas: Papirus, 1994.

RIBEIRO, M. M. A ciência dos trópicos: a arte médica no Brasil do século XVIII. São Paulo: Hucitec, 1997.

SIMÕES, M. P. S. G. Criaturas fantásticas da Amazônia. Belém: Editora da UFPA, 2000.

SOUZA, L. de M. e. Inferno Atlântico: demonologia e colonização: séculos XVI-XVIII. São Paulo: Companhia das Letras, 2009.

O diabo e a Terra de Santa Cruz: feitiçaria e religiosidade popular no Brasil colonial. São Paulo: Companhia das Letras, 2011. 
TAUNAY, A. de E. Zoologia fantástica do Brasil: séculos XVI e XVII. São Paulo: Edusp/Museu Paulista, 1999.

TEIXEIRA, N. Numa terra de estranhos: um Brasil que medrava no século XVI. Tese (Doutorado em Filosofia). Universidade do Porto, 2004.

VIVEIROS DE CASTRO, E. Araweté: os deuses canibais. Rio de Janeiro: Jorge Zahar, 1986. 


\title{
HISTÓRIA E MEMÓRIA: OS TUPINAMBÁ E O SEU TEMPO ${ }^{1}$
}

\author{
Ana Paula da Silva
}

Porque tengo mis manos, dice

Porque tengo mi lengua

Y porque tengo mi boca, dice

Porque mis huellas, dice

Porque tengo mis manos, dice

Porque tengo mi lengua, dice

Porque estoy hablando con humildad, dice

Porque estoy hablando nada más

Nga kgo, nga tí

Hablando con humildad.

María Sabina, la sabia de los hongos

A chegada dos europeus no atual território brasileiro marcou profundamente a vida, a história de diversos grupos indígenas que aqui viviam. Durante o processo de colonização, muitos foram exterminados, outros, porém, frente à nova realidade dialogaram, criaram

$1 \mathrm{O}$ artigo é parte de dissertação de mestrado intitulada Narradores Tupinambá e etnosaberes nas crônicas francesas do Rio de Janeiro (1555-78) e do Maranhão (1612-15), defendida em março de 2011, no PPGMS-Unirio, sob a orientação do professor José Ribamar Bessa Freire.

2 Doutoranda do PPGMS-Unirio, bolsista capes. 
estratégias de convívio, reconfiguraram suas identidades, atuando como agentes históricos. Nesse cenário de permanências e rupturas estão inseridos os Tupi da costa, que surgem constantemente nos livros de d'Abbeville e d'Évreux como Tupinambá - aliados dos franceses habitam, no século XVI, em um território que ia de Bertioga a Cabo Frio, do Recôncavo Baiano até a foz do São Francisco e nos Setecentos viviam do Rio Grande do Norte ao Maranhão (Perrone-Moisés; Sztutman, 2010).

De modo geral, a questão dos etnônimos é bastante complexa e nas palavras de Viveiros de Castro (1993, p.32)é fruto da incompreensão da dinâmica étnica e política do socius ameríndio, da "natureza relativa e relacional das categorias étnicas, políticas e sociais indígenas". Nos séculos XVI e XVII termos como tupinambá, tupiniquim, tupinaé, temiminó, carijó, entre outros etnônimos, não são identidades substanciais e surgem de modo flutuante na documentação histórica (Perrone-Moisés; Sztutman, 2010, p.416).

Apesar dos determinantes culturais, em documentos do período colonial, como as crônicas, encontram-se informações selecionadas por europeus sobre práticas culturais, sociais e políticas dos ameríndios que possibilitam, entre outros aspectos, apreender o ponto de vista dos indígenas, reencontrar suas trajetórias, restituir-lhes suas agências no processo histórico.

Deste modo, o objetivo deste artigo é discutir a trajetória de alguns índios tupinambás, que dialogaram com os franceses Claude d'Abbeville, em sua História da missão dos padres capuchinhos na ilha do Maranhão e terras circunvizinhas, editada em 1614, e Yves d'Évreux, ${ }^{3}$ em História das coisas mais memoráveis, ocorridas no Maranhão nos anos de 1613 a 1614, publicada apenas em 1864. Outra questão que se coloca é como evidenciar processos de agenciamentos indígenas nos relatos dos missionários?

3 Os missionários estiveram na atual Ilha de São Luís do Maranhão, no século XVII, durante uma tentativa de colonização francesa na América portuguesa, período conhecido historicamente como França Equinocial. 
A partir da metodologia proposta por Monod-Becquelin, no artigo "La Parole et la tradition orale amérindiennes dans les récits des choniqueurs aux XVI ${ }^{e}$ et XVII ${ }^{e}$ siècles", de 1984, mapeamos e identificamos os discursos registrados pelos capuchinhos. Segundo a autora, na documentação do período colonial existem três formas de registros:

a) O primeiro caso são os relatos registrados em língua fonte (indígena), seguidos ou não de tradução na língua do cronista. Esse tipo de discurso é mais constante nos livros de Jean de Léry, Claude d'Abbeville e Ives d'Évreux.

b) O segundo é o registro do discurso em estilo indireto e traduzido, onde os enunciados são explicitamente ouvidos da boca indígena, recolhidos no local e registrados pelo cronista. Neste caso, houve, portanto, um contato real entre os narradores indígenas e os cronistas europeus. Constituem exemplos as crônicas de Léry, d'Abbeville, d'Évreux, Cardim, Staden, Gabriel Soares de Souza.

c) O terceiro caso tem o francês como língua fonte. Alguns termos da língua indígena não possuem tradução correspondente na língua estrangeira, mas outros sim.

Monod-Becquelin assinala, ainda, as informações relacionadas às narrativas orais - as performances dos narradores, os variados gêneros e estilos existentes, as circunstâncias de narração, conversas, as interações com a plateia, entre outros aspectos. Essencialmente não verbal, esse tipo de comunicação, conforme Monod-Becquelin, é mais simbólica e foi pouco registrada por autores coloniais. A partir dessa abordagem metodológica chegamos aos discursos tupis, às suas trajetórias de vida. 


\section{Tupinambás e missionários: oralidade e escrita}

Partindo de um diálogo interdisciplinar entre a história, a antropologia e a crítica literária, nossa abordagem está inserida na chamada "Nova História Indígena", como vem sendo chamada por alguns pesquisadores, que procura compreender os ameríndios como agentes dos processos históricos e propõe o deslocamento do olhar para o papel ativo e criativo dos índios na história brasileira (Monteiro, 2007, p.5). Os documentos coloniais são importantes registros etnográficos produzidos, entre outros, por missionários e viajantes em contextos específicos, que "nos permitem um certo grau de segurança na reconstrução" dos grupos indígenas, como salientou Carlos Fausto (1992, p.381). Nesse processo de encontro entre mundos diversos é preciso uma análise crítica documental em função das limitações existentes. Por isso, cabe avaliar os contextos de produção das fontes - elemento importante para discussão, mas que não será aqui privilegiado-, definindo o lugar e o papel dos atores sociais, seus interesses e conflitos. Outro ponto relevante é compreender os documentos históricos como narrativas nas quais "se depositam inúmeras vozes, em contraponto ou em uníssono, e em diferentes tempos. Nesse sentido, também a voz indígena se apresenta como interlocutora" (Montero, 2006, p.12-13).

Conforme Portugal (2013), as crônicas do século XVI - acrescentaríamos as fontes dos Setecentos - representam o resultado da junção entre diferentes discursos espanhóis e indígenas que recorriam às suas referências culturais, buscando conhecer o outro. Portanto, são documentos construídos não apenas a partir das observações dos seus autores e intérpretes, porém das vozes de diversos indígenas, registradas pelos europeus, mas que seguem emudecidas e esquecidas pela historiografia tradicional brasileira. Os trajetos desses índios que viviam na América portuguesa permanecem dispersos, fragmentados na vasta documentação colonial e encontram-se adormecidos nos arquivos. Cabe notar que nem todos os indígenas que dialogaram com os cronistas foram identificados. É o caso do relato de Jean de Léry, História de uma viagem feita ao Brasil (1578), em que os 
índios eclodem anônimos, surgindo especialmente individualizados na figura do "ancião", de "um certo índio", "uma certa índia”, "os velhos”. Já os cronistas d'Abbeville e d'Évreux identificaram a maioria de seus interlocutores, sendo esta uma das características marcantes de seus relatos. Assim o fez André Thevet em menor medida nos livros Singularidades da França Antártica (1557) e Cosmografia universal (1575). ${ }^{4} \mathrm{Na}$ maioria dos casos, as vozes indígenas nos livros capuchinhos surgem na primeira pessoa, enquanto em Thevet (não todas) e Léry são mais impessoais, caracterizadas por: "os anciãos", "eles dizem”, "a mulher", "disse-nos", "os selvagens".

Ao refletirmos sobre as limitações das fontes, nos interrogamos acerca das possibilidades de pesquisa também. Isso nos coloca diante da delicada tarefa de recuperar nas nuances das entrelinhas, no olhar construído do cronista, portanto no texto, a perspectiva indígena. Nas fontes capuchinhas identificamos distintos tipos de narrativas indígenas. As falas aparecem por meio de diálogos, conversas, discursos específicos como as harange - tipo de discurso solene, proferido por chefes, morubixaba, nas assembleias ou diante de uma personagem importante (Daher, 2004) - tais como: os discursos de Japí Guaçú, Momboré Guaçú, Jaguára Abaété, Ybyrápytáng, Acajuí, Pacamũ ${ }^{5}$ e diversos outros.

O ameríndio dotado de palavras ajuda a fundamentar a representação do indígena amigável e, gentilmente, convertível, como evidenciou a historiadora Andrea Daher (2007). No entanto, suas falas não podem ser reduzidas a uma ferramenta de validação, pura e simples, do projeto de colonização e conversão francês, ainda que "se reconheça a sua dimensão político-ideológica" (Montero, 2006,

4 Para realizarmos essa breve comparação, privilegiamos apenas os relatos de quatro autores franceses que estiveram no Brasil com os Tupi da costa, no Rio de Janeiro do século XVI (André Thevet e Jean de Léry) e no Maranhão dos Setecentos (Claude d'Abbeville e Yvés d'Évreux).

5 Informo que o processo de restauração dos verbetes da língua tupinambá, registrados pelos franceses, foi realizado com auxílio da linguista Ruth Monserrat e a partir do cotejo de documentos históricos dos séculos XVI e XVII, relacionados à língua tupinambá. 
p.33). Segundo o pesquisador Lienhard (1992), para organizar a base colonial na América hispânica foi necessário conhecer as estruturas políticas, socioculturais dos ameríndios. Para isso, os funcionários coloniais recolheram declarações por escrito de milhares de indígenas sobre os mais variados aspectos.

Ao analisar essa documentação, Lienhard salienta que em todo o período colonial era comum "dar a palavra" aos indígenas. A necessidade de "falar" com as autoridades europeias e criollas obrigou os ameríndios a criarem uma estratégia discursiva interessante: o discurso destinado aos "extraños". Trata-se de um tipo de discurso distinto, capaz de chegar aos ouvidos ou aos olhos dos inimigos ou possíveis aliados. Os indígenas não apenas aprenderam a dominar os códigos da fala dos europeus, como também aprenderam a caminhar no universo da escrita.

Essa estratégia de apropriação indígena dos códigos discursivos e retóricos europeus não apenas validavam os objetivos dos capuchinhos, mas também os interesses dos Tupinambá. Os índios dotados de fala nos textos de Claude d'Abbeville e Yves d'Évreux criaram um tipo de discurso que correspondia às expectativas dos franceses, pois também tinham interesses nas alianças e no apoio contra seus inimigos, fossem estes outros grupos rivais ou as ameaças iminentes dos portugueses. Sendo assim, os Tupinambá que aparecem nos livros dos capuchinhos não são apenas dóceis e passíveis de conversão. Existem outras possibilidades de leitura que evidenciam o papel ativo e criativo dos índios no período colonial.

\section{Vidas ameríndias}

As biografias dos índios foram pensadas a partir de uma pesquisa incessante por dados biográficos muito tênues e pela mescla dessas informações com elementos de suas narrativas que permitissem alguns comentários sobre aspectos da cultura dos Tupi da costa ou mesmo dos processos dinâmicos com os franceses. Realizamos ainda o cotejo desses dados com diferentes documentos, quando possível, 
para compor suas histórias. Nas duas obras foram encontrados alguns indígenas, essencialmente masculinos, sendo identificadas raríssimas vozes femininas e infantis. Em ordem alfabética, apresentamos parte desses personagens históricos, esperando dar-lhes visibilidade.

\section{Acajuí Mirĩ}

Para d'Abbeville, esse pequeno índio era belo, inteligente e apresentava enorme desejo de aprender a liturgia católica. Através da fala e da repetição - características da oralidade -, o menino auxiliava os franceses no projeto de catequização das almas "selvagens", ensinando outras crianças tudo que aprendia com os padres. $\mathrm{O}$ padre escreve orgulhoso que Acajuí Mirî munido de uma varinha ou com a ponta dos dedos escrevia o que sabia na areia e ensinava as demais crianças. Acajuí Mirĩ tecia na terra palavras incompreendidas por vezes, porém repetidas incansavelmente até sua memorização, segundo consta na crônica. Desta forma, como num passe de mágica, dava vida ao Oré-ruba ybac-pét-ekó-ara |Ore-ruue vuac peté cuare|; Santa Maria Tupã sy | Santa Maria Toupã seu, ${ }^{6}$ conforme registrou o padre.

No anseio de catequizar os índios ensinava-se o Oré-ruba, ou seja, a oração cristã Pai nosso, mas na língua tupinambá o pronome possessivo oré é empregado nos casos em que o "nosso" não inclui a pessoa ou as pessoas com quem se fala. Freire (2009) chama a atenção para o problema da tradução de universos culturais e linguísticos muito distintos. Segundo o pesquisador, nas frases em tupinambá supracitadas percebe-se a falta de habilidade e conhecimento da língua indígena pelos missionários. Fato que gerou "erros primários" quase "folclóricos". Freire explica que essa língua indígena possui dois pronomes possessivos de primeira pessoa do plural. Para incluir o interlocutor na fala emprega-se o "iandé" ou "nhandé" e não o ore, exclusivo. $\mathrm{O}$

6 Pai nosso que estais no céu; Santa Maria mãe de Deus. Respectivamente, Oração do Senhor e Oração à Virgem. As mesmas frases aparecem na crônica de d'Évreux. 
padre Lemos Barbosa (1956), que foi professor da língua tupinambá na PUC do Rio de Janeiro, enfatiza que a profunda diversidade cultural entre indígenas e colonizadores não encontra fácil equivalência nos dicionários.

Na obra de d'Abbeville, as falas do jovem índio recaem sobretudo na comprovação do projeto de catequização, como na história a seguir.

Pegando ossinhos e cousas semelhantes indagava do sr. de Rasilly: Morubixaba de acã omanô? "Dói-vos a cabeça, senhor?" depois soprava e esfregava o lugar da dor imaginária e mostrava o que trazia na mão, dizendo ser o objeto a causa da doença. Fazia desse modo rir a companhia, provocava a admiração dos velhos e desmoralizava os pajés que passavam a ser considerados mentirosos e embusteiros. (D’Abbeville, 1975, p.254)

Longe de ser apenas uma "brincadeira de criança" a atitude de Acajuí Mirĩ no livro é intencional e carregada de sentidos. Não por acaso foi selecionada pelo cronista. Ao incluí-la propositadamente em seu livro, o autor dialoga com seus possíveis leitores na França, sobretudo com a corte francesa, pois os capuchinhos participaram da expedição, ordenados pela rainha Maria de Médici.

A conversão dos ameríndios era prova da eficiência e necessidade de catequização. D'Abbeville permaneceu entre os Tupinambá apenas quatro meses, por isso não ficou tempo suficiente para ver o jovem Acajuí Mirĩ recusar sua condição de cristão e retornar ao que os jesuítas rotulavam como "maus costumes". Quem nos conta esse retorno do jovem indígena é seu pai Acajuí, citado por d'Évreux:

meu filho que, logo que se tornou cristão, aprendia bem, já sabia ler um pouco no seu Kuatiara [espécie de cartilha] e formar as letras, estava sempre com o Pai, seguiu-o por toda parte, mas abandonou tudo entregando-se à liberdade, está esquecendo o que aprendeu e, quando vê que o Pai o está procurando, foge para o mato. (D' Évreux, 2009, p.454) 
O tema da inconstância da alma selvagem é recorrente na literatura colonial. Para Viveiros de Castro (2002), ela passou a ser um elemento definidor do caráter tupinambá, que se consolidou como um dos estereótipos do imaginário nacional. De acordo com o antropólogo, se não era um modo de ser, a inconstância era um modo de aparecer da sociedade tupinambá aos missionários.

\section{Caruatapirã}

Esse tupinambá é mencionado nas duas crônicas capuchinhas. Delineado a partir da sua reputação de bravo guerreiro, esse chefe escreve d'Abbeville - havia partido para uma guerra no momento da sua chegada ao Maranhão. As fontes dizem apenas que ele era da aldeia de Cumá e que tinha um irmão chamado Jaguaracic. Novamente quando é mencionado na História da missão, oferece aos franceses alguns cativos que trouxera do Amazonas.

A fim de mostrar a amizade que tinha aos franceses, reservara-lhes alguns desses escravos originários do rio Amazonas [...] Trouxe no seu regresso madrepérola, afirmando ter visto pérolas muito apreciadas pelos negociantes franceses pela amostra que lhes deu ao Sr. de Rasilly. (D'Abbeville, 1975, p.121, grifos nossos)

No jogo de sedução do "Outro", o europeu, também valia incitar a sua cobiça e, não raro surgem - entre um capítulo e outro - vozes que mencionam a riqueza do solo, como no trecho acima selecionado. Essa evidência também funcionava como um artifício para aqueles que desejavam o financiamento da empresa francesa no Maranhão, pois, além de "almas" para converter, era necessário um argumento mais atrativo, que provasse por todos os meios ser possível a relevância de uma colônia no Brasil, visto que outras tentativas nesse sentido não foram bem-sucedidas.

Além da "diplomacia” tupinambá, Caruatapirã fala sobre a guerra contra seus inimigos. Em conversas com d'Évreux, ele narra um 
desses episódios de guerra contra os Tremembé e como estes matavam seus inimigos. Ressaltamos as informações que ele nos diz sobre a morte de um dos filhos do principal de Janypá-rã e de como os Tremembé faziam seus machados. De posse de um desses instrumentos, ainda manchado de sangue e com alguns fios de cabelo do morto, ele ensina ao cronista:

algo que eu não sabia a respeito daqueles machados, feitos de pedra muito dura, e esculpidos em forma de meia-lua; explicou-me que os tremembés tinham por hábito, todos os meses, no primeiro dia da lua crescente, passar a noite fabricando esses machados até ficarem perfeitos. Acreditavam, por superstição, que, com essas armas, nunca seriam vencidos na guerra, e a vitória sobre o inimigo sempre seria deles. Enquanto os homens e as mulheres se entregavam a esse trabalho, dançavam as moças e os meninos à frente nas choupanas ao luar do crescente. (D’Évreux, 2009, p.248-9)

Em artigo sobre esse grupo inimigo dos Tupinambá, Leite (2009) confirma as palavras de Caruatapirã. Nos seus estudos a pesquisadora atesta a fabricação do machado semilunar, curvilíneo feito pelos homens tremembés, em noite de lua crescente, enquanto as mulheres, jovens e crianças dançavam o Torém. ${ }^{7}$

\section{Filha de Japí Guaçú}

Existem poucas informações sobre essa ameríndia. Sabe-se apenas que era filha do morubixaba Japí Guaçu. Ela sai da função de espectadora para narrar a Yves d'Évreux uma importante prática social dos Tupinambá: o "serviço da noiva".

7 Também denominada de Toré, esse ritual-hoje-é uma das práticas mais difundidas entre os grupos indígenas que buscam a sua afirmação étnica, sobretudo no Nordeste. Nesse contexto, esse processo de transmissão cultural pode ser entendido de diferentes formas. 
Embora esse rapaz esteja casado, e a moça também, tal fato não os isenta da obrigação natural de assistir os pais; pelo contrário continuam obrigados a ajudá-los nos trabalhos da terra e a socorrê-los. É uma advertência que foi feita, em minha cabana, pela filha de Japí Guaçú, batizada e casada na igreja, para um outro selvagem, seu marido, também cristão, que estava indo para Tapúi-tapéra auxiliar o Pe. Arsênio, a batizar numerosos selvagens. Ela disse o seguinte: "Para onde queres ir? Tu bens sabes muito bem que há ainda muito trabalho para fazer nas roças de meu pai, e faltam mantimentos. Não sabes que se ele me entregou a ti para que o ajudasse na velhice? Se queres abandoná-lo, vou voltar para a casa dele. (D’Évreux, 2009, p.174, grifo nosso)

A capacidade de adquirir "cunhados" e "genros" era um dos predicados dos chefes indígenas, constituíam formas de aquisição de prestígio e poder. Ter um número significativo de mulheres implicava não se sujeitar ao "serviço de noiva”. Sabe-se que os Tupinambá eram, temporariamente, uxorilocais. Esta, por sua vez, é uma regra de residência onde o genro mora na casa dos pais da noiva para, obrigatoriamente, colaborar e trabalhar junto com o sogro (Viveiros de Castro, 2002; Fausto, 1992).

\section{Itápucú}

De acordo com d'Abbeville, Itápucú nasceu na aldeia de Caiété e seus pais seriam o principal Guará Guaçú e Guirá-jará. Tinha mais ou menos 38 anos quando embarcou, em primeiro de dezembro de 1612, com d'Abbeville rumo à Paris. ${ }^{8}$ Era chamado também de Itápyçã, porém teria mais de dez outros nomes adquiridos nas guerras contra seus inimigos, conforme apontamentos das fontes. É interessante notar que na gravura feita por Leonard Gaulthier,

8 Os seis ameríndios que viajaram com d'Abbeville foram: Caripirá, Itápucú, Manẽ, Patuá, Guarajú e Japuaí. 
Itápucú aparece sem as suas escarificações, que evidenciavam a sua posição de destaque dentro da sociedade tupinambá.

Na imagem, o artista o pinta como um índio "civilizado", passível de conversão, vestido à francesa - roupas, sapatos - e, segurando um lírio, símbolo da França na época. D’Abbeville utiliza o que Hartog (1991) denomina de inversão para traduzir aos seus leitores a imagem que ele cria desse ameríndio. O "índio civilizado" aproxima dois mundos distintos e reforça a ideia de conversão do missionário, evidenciando a intencionalidade da imagem que não representava a realidade, mas uma visão de mundo.

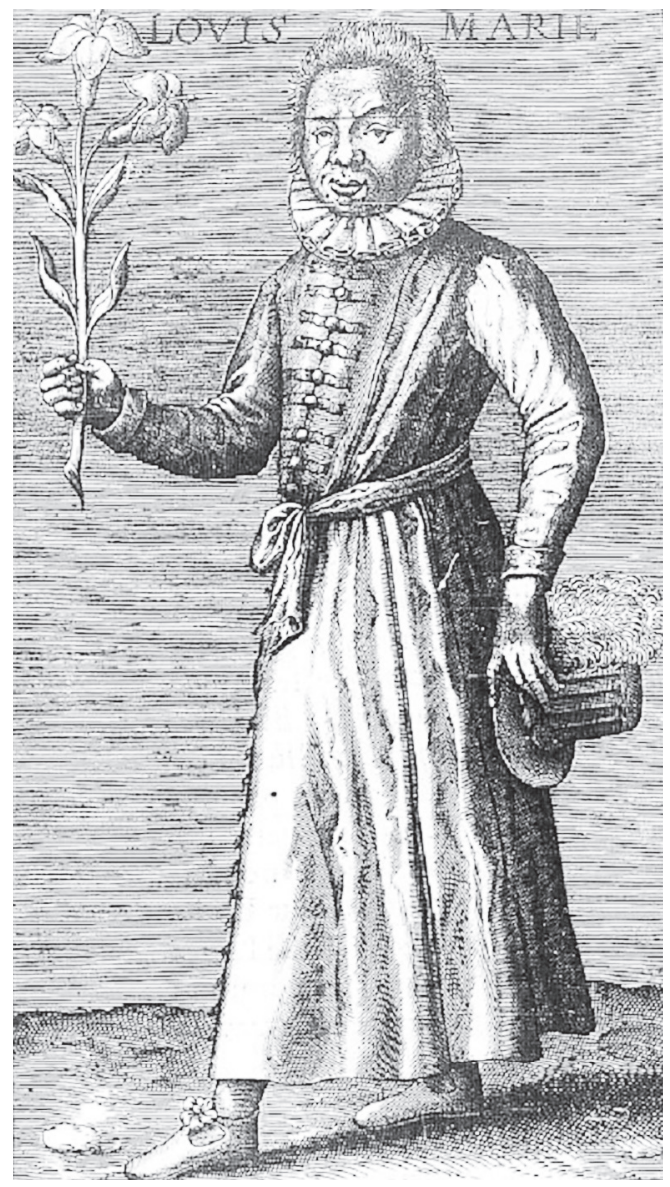


No relato do capuchinho francês (1975, p.276), Itápucú é descrito como grande orador. "Compraz-se grandemente em fazer discursos e não se cansa jamais de falar a respeito de seus feitos guerreiros e de nossa fé." Seu andar, sua maneira de discursar evidenciavam para d'Abbeville a postura de guerreiro destemido. Porém, não é essa a leitura que fazemos de sua gravura. Conforme Chincangana-Bayona (2006, p.21), a ideia de etnografia do século XVI estava baseada nos detalhes externos - nas indumentárias, nos adornos e artefatos que os indivíduos usavam. Ao tecer uma comparação entre as imagens de Caripirá e Guarajú, ${ }^{9}$ Chincangana-Bayona destaca que o fato do último ter sido batizado, evangelizado, convivido com os padres e ter aprendido o modo de vida francês, seria mais civilizado, "domesticado".

De igual modo, interpretamos as imagens de Itapucú e Japuaí em contraposição às iconografias de Caripirá, Manẽ e Patuá que estão seminus, com arcos e flechas. Portanto, os indígenas "civilizados" materializavam a possibilidade do projeto francês de colonização no Maranhão e a expansão da fé católica na região.

\section{Pacamũ}

Esse xamã, de fama renomada na região de Cumá, fala em duas conferências que teve com d'Évreux. O padre menciona que a liderança indígena estava sempre com o cachimbo na boca e soltando fumaça pelas narinas. Com a voz grave e pausada, conversou sobre sua trajetória de glória que teria conquistado através de sangrentas batalhas e não pela imposição de seu poder de xamã. O padre o descreve como "Grande soprador", menção ao modo como os xamãs obtinham a cura dos enfermos. Era baixo e considerado muito feio por d'Évreux, porém bastante respeitado entre os Tupinambá.

O padre descreveu alguns hábitos dos xamãs. Segundo ele, essas lideranças espirituais eram solitárias, de poucas falas, reclusos, muito

9 Na crônica de d'Abbeville o nome desse índio aparece grafado como Uaruajó. 
estimados e respeitados pelos índios. Abaixo citamos uma cerimônia xamanística narrada por Pacamũ.

Aqueles sopros lhes são bem particulares, como cerimônia absolutamente necessária à cura dos enfermos, pois vós podeis vê-los puxar, tanto quanto podem, com a boca, o mal do doente, conforme dizem. Fazem de conta que estão com a boca estourando de tão cheia, e soltam de uma só vez aquele vento, com um barulho semelhante a um tiro de pistola; cospem então com toda força, que aquiloé o mal que sorveram, e tratam de convencer o doente. (D'Évreux, 2009, p.408)

Nessa cerimônia performática eram retirados objetos de diferentes naturezas: madeira, metal, ossos, que representavam a doença do enfermo. Em outra narrativa, Pacamũ conta a cura de um menino da aldeia de Uçaáb, que apresentava dores muito fortes no abdômenfrancês Ao final da cerimônia de cura, realizada com auxílio de outro xamã, foram retirados três preguinhos da barriga da criança. Isso deixou o cronista admirado, pois como poderiam mostrar pregos, se estes não eram objetos comuns entre os indígenas?

Além de falar sobre suas práticas xamanísticas, Pacamũ contou a d'Évreux histórias míticas relacionadas ao tempo do dilúvio e sobre o papel ambíguo dos xamãs, como na frase seguinte: "Eu mandava virem anos de fartura e me vingava dos que me desprezavam por meio de doenças".

\section{Patuá}

Natural da atual Ilha de São Luís do Maranhão, descendia de uma família de prestígio. Seu pai era Abatí-pirã, um dos principais chefes da Ilha, seu avô era Marcoiá peró, chefe indígena da aldeia de Carnaú-biób. Tinha entre 15 e 16 anos quando foi à França com mais cinco tupinambás. D'Abbeville o descreve como um indígena bem-feito de corpo, dócil, inteligente. É dessa maneira que o artista Gaultier eterniza o jovem tupinambá, em Paris. 
Chama-nos atenção o fato dos tupinambás mortos na França terem sido representados nus, como se estivessem no Maranhão, segurando seus arcos e flechas, sendo apenas Caripirá - por ser um afamado guerreiro - pintado com o tacape e as escarificações. Essas imagens são muito reveladoras, pois os índios nus representam os tupinambás antropófagos, bárbaros, que em alguma medida simbolizava o Maranhão dos selvagens. Já os índios vestidos, "domesticados", conforme visto acima, constituíam a ascensão ao modo de vida do europeu.

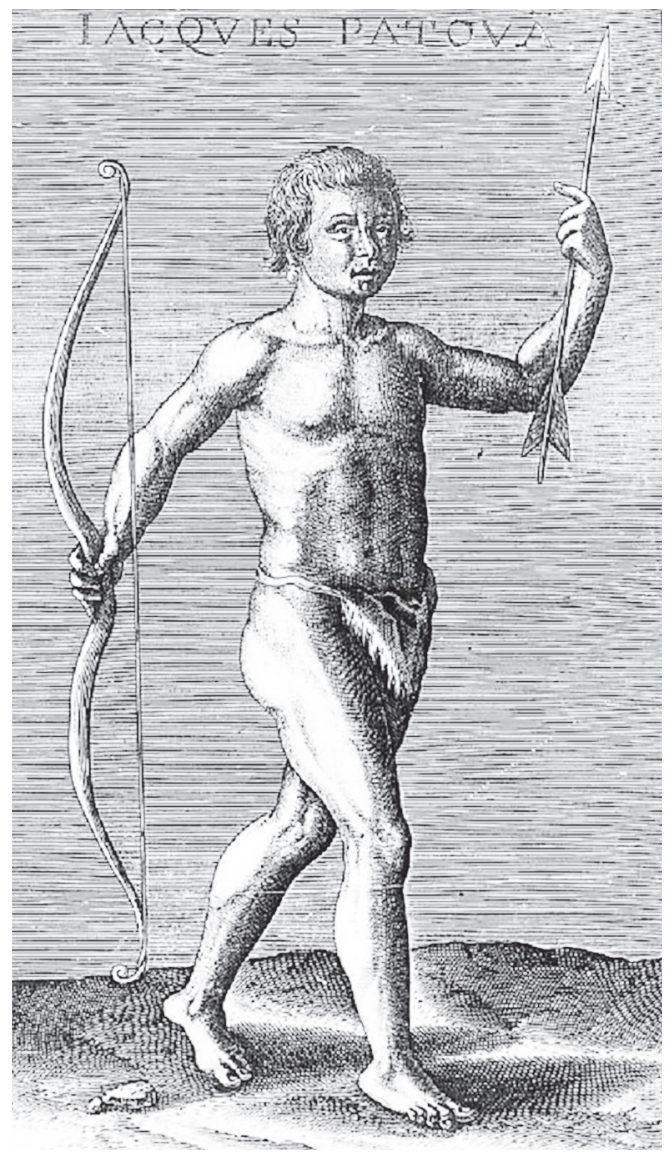


Na História da missão, assim como Caripirá e Manẽ, Patuá teve febre, dores, paralisia e alucinações. O caso desse índio é bastante peculiar. Ele dizia ver "indiozinhos que o ameaçavam com pancadas, se pedisse o batismo". Longe de serem as artimanhas do diabo - como foram assim compreendidas pelo capuchinho-, talvez no mais íntimo de sua consciência a morte longe de sua terra, de sua família, de seus costumes, tenha gerado um momento de crise e as visões são formas de expor o conflito interno que imaginamos ter vivido. $\mathrm{O}$ fato de terem sido "indiozinhos" os espectros que o atormentaram pode ser a chave para essa interpretação.

Patuá foi batizado em 4 de maio com o nome de Tiago, faleceu dois dias depois e foi sepultado no convento dos capuchinhos em Paris. ${ }^{10}$

\section{Considerações finais}

Como vimos, os documentos coloniais são resultados de uma interação entre os europeus e os indígenas, que nos permitem estudar distintos aspectos de sociedades ameríndias extintas $-\mathrm{e}$ atuais inclusive - durante o processo de colonização, tais como: organização social, política, cosmologias, saberes tradicionais que circulavam no âmbito da oralidade. Possibilitam, ainda, analisar o trajeto de atores indígenas que nesses contextos de interação cultural e política incorporaram categorias e tecnologias do colonizador, por exemplo, a escrita, seus suportes específicos e o novo conjunto de práticas a ela associadas, entre outros.

10 De acordo com recentes informações dadas ao professor Bessa Freire pelo frei Pio Murat, diretor da Bibliothèque Franciscaine Provinciale des Capucins de Paris, o cemitério particular dos capuchinhos, localizado até o início do século XIX no convento da rue Saint-Honoré, foi desativado no período do Consulado, primeira fase do governo de Napoleão Bonaparte, quando os cemitérios foram secularizados. Nesse período, os restos mortais ali presentes, entre os quais os de Caripirá, Manẽ e Pautá, foram transferidos para as Catacumbas de Denfert Rochereau (Paris, XIV), onde permanecem até os dias de hoje, sem qualquer menção específica aos índios, apenas com uma indicação genérica ao cemitério. 
Diferente dos Andes - onde encontramos versões nativas do processo de colonização, como é o caso da crônica Nueva Corónica y buen gobierno, de Guamán Poma de Ayala -, na América portuguesa existem parcas fontes e iconografias de autoria indígena, salvo alguns documentos como as cartas dos chefes indígenas Felipe Camarão e Pedro Poty, ambos potiguara. Ao evidenciarmos, no entanto, esses indígenas, chamamos atenção para as possibilidades de pesquisa a partir dos discursos, haranges, das biografias indígenas, campos pouco explorados pela historiografia.

Enfocando o olhar no papel ativo e criativo dos índios, repensamos, a partir de um diálogo interdisciplinar, a dinâmica da vida social e da construção de identidades nas interações franco-tupis, particularmente no século XVII. Longe de compreender os ameríndios a partir de visões essencializadas, eles foram protagonistas que dialogaram com os novos tempos, apropriaram ou rejeitaram elementos disponíveis no repertório cultural do invasor como seus códigos discursivos, retóricos. Assim dotados de fala, criaram um tipo de discurso novo, peculiar e bastante sedutor.

O discurso destinado aos "extraños" deve ser compreendido como resultado de disputas simbólicas, no contexto de colonização, e não simplesmente uma ferramenta de validação dos projetos de conquista e catequização europeus. Apesar das limitações e das lacunas documentais, é possível evidenciar a criatividade e dinamicidade dos Tupi diante da nova realidade imposta por europeus. Os estudos sobre as sociedades indígenas no período colonial vêm demonstrando que a emergência de novos atores sociais não é um fenômeno exclusivo dos dias atuais.

\section{Referências bibliográficas}

CHICANGANA-BAYONA, Y. A. Do Apolo de Belvedere ao Guerreiro Tupinambá: etnografia e convenções renascentistas. Revista História, São Paulo, v.25, n.2, p.15-47, 2006. Disponível em: <http://www.scielo.br/pdf/his/ v25n2/01.pdf>. Acesso em: maio 2009. 
CONTURSI, M. E.; FERRO, F. La narración: usos y teorias. Bogotá: Norma, 2000.

D’ABBEVILLE, C. História da missão dos padres capuchinhos na Ilha do Maranhão e terras circunvizinhas. Trad. Sérgio Milliet. Belo Horizonte; São Paulo: Itatiaia; Edusp, 1975 [1614].

DAHER, A. O Brasil francês: as singularidades da França Equinocial, 16121615. Rio de Janeiro: Civilização Brasileira, 2007.

A conversão dos Tupinambás entre a oralidade e a escrita nos relatos franceses dos séculos XVI e XVII. Horizontes Antropológicos, Porto Alegre, ano 10, n.22, p.67-92, jul.-dez. 2004.

DENIS, F. O padre Yves d'Évreux e as primeiras missões no Maranhão. In: D'ÉVREUX, Y. História das coisas mais memoráveis, ocorridas no Maranhão nos anos de 1613 e 1614. Trad. Marcella Mortara. Rio de Janeiro: Batel, 2009 [1864]. (Coleção Os Franceses no Brasil, v.4.)

D'ÉVREUX, Y. História das coisas mais memoráveis, ocorridas no Maranhão nos anos de 1613 e 1614. Trad. Marcella Mortara. Rio de Janeiro: Batel, 2009 [1864]. (Coleção Os Franceses no Brasil, v.4.)

FAUSTO, C. Fragmentos de história e cultura tupinambá: da etnologia como instrumento crítico de conhecimento crítico de conhecimento etno-histórico. In: CUNHA, M. C. (Org.). História dos índios no Brasil. São Paulo: Companhia das Letras, 1992, p.381-96.

FREIRE, J. R. B. Tradução e interculturalidade: o passarinho, a gaiola e o cesto. Rio de Janeiro: UFRJ, 2009. (Cadernos de Literatura.)

HARTOG, F. Oespelho de Heródoto: ensaio sobre a representação do outro. Belo Horizonte: UFMG, 1999.

LEITE, M. A. Resistência tremembé no Ceará: depoimentos e vivências. In: PALITOT, E. M. (Org.). Na mata do sabiá: contribuições sobre a presença indígena no Ceará. Fortaleza: Secult/Museu do Ceará/Imopec, 2009, p.401-19.

LEMOS BARBOSA, A. Curso de Tupi Antigo. Rio de Janeiro: Livraria São José, 1956.

LIENHARD, M. Testimonios, cartas y manifestos indígenas: desde la conquista hasta comienzos del siglo XX.Venezuela: Biblioteca Ayacucho, 1992.

MONOD-BECQUELIN, A. La Parole et la tradition orale amérindiennes dans les récits des choniqueurs aux XVI e et XVII e siècles. Ameríndia, Numéro spécial 6, CNRS, Paris, 1984.

MONTERO, P. Índios e missionários no Brasil: por uma teoria da mediação cultural. In: _ _ (org.). Deus na aldeia: missionários, índios e mediação cultural. São Paulo: Globo, 2006. 
MONTEIRO, J. Entre o etnocídio e a etnogênese: identidades indígenas e coloniais. In: FAUSTO, C.; MONTEIRO, J. (Orgs.). Tempos índios: histórias e narrativas do Novo Mundo. Lisboa: Assírio \& Alvim, 2007.

PERRONE-MOISES, B.; SZTUTMAN, R. Notícias de uma certa confederação Tamoio. Mana [online], 2010, v.16, n.2, p.401-433.

PORTUGAL. A. R. Discursos espanhóis e indígenas na história do Antigo Peru. Revista FSA, Teresina, v.10, n.4, art.12, p.215-238, out.-dez. 2013.

RODRIGUES, A. D. A contribuição linguística de Jean de Léry. In: LÉRY, J. História de uma viagem feita à terra do Brasil, também chamada América. Trad. Maria Ignez D. Estrada. Rio de Janeiro: Betel, Fundação Darcy Ribeiro, 2009. (Coleção Franceses no Brasil - Século XVI e XVII.)

VIVEIROS DE CASTRO, E. O mármore e a murta: sobre a inconstância da alma selvagem. In: A inconstância da alma selvagem - e outros ensaios de antropologia. São Paulo: Cosac \& Naify, 2002 [1992]. 


\title{
"De diversas lenguas de la GUARANI": AS REPRESENTAÇÕES SOBRE GUARANI E MACRO-JÊ NAS REDUCCIONES DO GUAYRA
}

\author{
Luiz Fernando Medeiros Rodrigues* \\ Gabriele Rodrigues de Moura**
}

\section{Introdução}

O presente artigo estuda as reducciones guaireñas, através dos minuciosos relatos dos missionários, sobretudo, os que foram descritos por Antonio Ruiz de Montoya. Nessas narrativas, oriundas de sua visão de mundo típica de um criollo, percebemos como dois grupos indígenas etno-linguisticamente distintos (os Tupi-Guaranie os Macro-jê) foram descritos. A leitura dos escritos de Montoya nos levou a identificar várias formas de escrituras. Para bem distingui-las, faz-se necessário compreender a sua forma mentis, profundamente marcada pela sua formação de jesuíta. O que nos leva a adentrarmos na análise das representações ${ }^{1}$ presentes nos seus escritos. Como

* Professor do PPGH da Unisinos. Este artigo é resultado das pesquisas feitas pelo autor no âmbito do projeto "A contribuição dos jesuítas expulsos, em 1759, para o conhecimento das culturas indígenas das missões do Grão-Pará e Maranhão”, que conta com a bolsa de pesquisa $\mathrm{PqG} /$ Fapergs.

** Professora da Unisinos. Este artigo foi o resultado das pesquisas feitas pela autora no âmbito do projeto "Jesuítas nas Américas", que contava com a bolsa de pesquisa Capes/Prosup, sob a orientação do prof. dr. Luiz Fernando Medeiros Rodrigues.

1 O conceito de representação teve a sua primeira definição no século XVIII, colocada no Diccionario de la Lengua Castellana, como "el acto de representar, ó hacer 
missionário da Companhia de Jesus em solo guaireño, Ruiz de Montoya dedicou-se não apenas a aprender a falar as línguas dos Guarani, Gualachos, Guayanas, Guañanas, Guayanases, Cabelludos e Coronados, mas também a lutar em favor do direito desses indígenas, como súditos da coroa espanhola. $\mathrm{O}$ impulso de seus talentos e virtudes e sua extensa produção documental fizeram que esse jesuíta fosse comparado, pelos seus companheiros de missão, com o grande missionário do Oriente, Francisco Javier; pelos indígenas, com os quais teve contato, com um poderosíssimo xamã; e, pelos historiadores, antropólogos e linguistas, com outros missionários que tiveram grande importância nas missões ${ }^{2}$ em solo americano, tais como: Huamán

una cosa (Reprcesentatio). [...] Figura, imágen, ó idea, que sustituye las veces de la realidad (Effigies, imago)", (Diccionario, 1780, p.797). Sua definição como forma de perceber e descrever o mundo viria com a criação do conceito sociológico sobre as representações religiosas ou coletivas, criada por Marcel Mauss e por Émile Durkheim, no século XIX (Durkheim, 1999). O conceito foi abandonado pelas ciências humanas, até a década de 1980, quando Roger Chartier o retoma, consagrando-o como categoria analítica da visão de mundo individual de alguém inserido dentro de um grupo específico (Chartier, 1990).

2 A palavra missão, nas cartas do superior geral Claudio Acquaviva (1581-1615), sempre é empregada no plural por estar estabelecida em várias partes do mundo e ser diversa. Pois, tanto as missões ad extra Europa quanto ad intra estão englobadas sob a mesma espiritualidade. A missão seria uma luta travada pelo amor de Cristo, sendo destinadas àqueles que possuíssem um fervor particular e um grande zelo (De Angelis, 1635, p.266-283 [§ 4]). "Essa dimensão de combate revela uma forma de inquietação; o apelo à missão repousa sobre a constatação de uma situação religiosa muito grave frente à qual os jesuítas não podem permanecer inativos. Na carta [De fervore \& zelo miffionum, escrita por Acquaviva] sobre o zelo, a descrição de um mundo desnaturado pelo Mal no qual só há pecados, trevas, fogueiras das vaidades, tem um valor universal, e todo jesuíta, onde quer que esteja, deve se sentir chamado e ser tomado de um 'fervor' e de um 'zelo' para as missões. Esse mundo do Mal lembra tanto as descrições heréticas da velha Europa quanto as dos pagãos e dos colonos desnaturados do Novo Mundo. A missão parece assim como um combate contra as forças do Mal, cuja origem não é evocada, como se o mais importante fosse não obter uma vitória, mas travar o combate" (Castelnau-L'Estoile, 2006, p.307). Prossegue a autora afirmando que dentro da "visão binária do mundo que têm os jesuítas, na qual os 'nossos' se opõem aos 'outros', há a partir de então a ideia de que os 'outros' podem pôr os 'nossos' em perigo" (ibid., p.309-310). No caso específico, a autora está se referindo à questão de perigo da salvação das almas dos jesuítas, devido 
Poma de Ayala (1534-1615), Bernardino de Sahagún (1499-1540), José de Anchieta (1534-1597), Bartolomé de Las Casas (1474-1566), José de Acosta (1539-1600). Viveu entre os indígenas aproximadamente 25 anos, observando seus costumes cotidianos, sua religiosidade, suas características físicas e linguísticas. Isto possibilitou fazer um acurado registro das principais diferenças apresentadas pelas tribos por ele catequizadas. O nosso recorte temporal abrange os anos de 1611 até 1652, como forma de conhecer, além da sua vasta produção documental, elementos que foram fundamentais para a sua forma mentis. Esse eixo cronológico inicia com a chegada de Montoya a Assunção e se encerra com a sua morte em Lima. Esse momento coincide igualmente com período que vai do início à destruição das reducciones (1631), fim da história do Guairá. A sua análise é importante para compreendermos as características que particularizam a sua escrita em dois momentos diferentes e sucessivos: na sua estadia na corte madrileña (1638-1643) e após o seu retorno à cidade de Lima (1643). O território guaireño não existe mais como um espaço físico, tornando-se um lugar de memória que transpõe as barreiras do tempo. As representações de Ruiz de Montoya se deslocarão para a sua memória, vivida no âmbito daquele espaço (não mais físico)e, portanto, que já não é mais o mesmo. Em outras palavras, o novo espaço de representação é a sua memória particular sobre os índios.

\section{Antonio Ruiz de Montoya}

Antonio Ruiz nasceu na Ciudad de los Reyes (Lima, Perú), em 13 de junho de 1585, filho natural de Cristóbal Ruiz (espanhol de

às várias acusações que alguns que viviam dentro das aldeias no Brasil acabaram sofrendo durante o século XVI e início do XVII. Contudo, o perigo na América espanhola, na primeira metade do século XVII, o perigo que viria dos "outros" estaria mais relacionado à questão de morte, ou pelas mãos de indígenas ou pelos bandeirantes, como aconteceu nos casos de Roque González de Santa Cruz, Juan del Castillo, Alonso Rodríguez, Cristóbal de Mendoza, Diego de Alfaro, Pedro Romero, entre outros. 
Sevilha) e de Ana Vargas (limenha). Aos 5 anos, ficou órfão de mãe, sendo educado pelo pai, que pretendia levá-lo para a Espanha, onde seria educado de maneira cristã. Porém, isto não foi possível porque adoeceu, fazendo que o pai desistisse da viagem e voltasse com ele para Lima. Aos 8 anos, perdeu o pai e teve que resolver por si próprio os rumos de sua vida. Foi nesta etapa da sua vida que foi entregue aos cuidados de tutores (Jarque I, 1900, p.54-55). Estes respeitaram um único desejo de seus pais: matriculá-lo no Real Colegio San Martín, fundado pelos jesuítas na cidade.

Na juventude, passou a viver de maneira turbulenta, abandonou os estudos e seguiu o caminho de uma vida licenciosa, desperdiçando a herança que havia recebido (Jarque I, 1900, p.61-65). Entre seus 16 e 19 anos, por vezes, deparou-se com situações que o colocaram em perigo de perder a vida (Aguilar, 2002, p.147). Tais fatos tiveram como consequência as ameaças de prisão e o perigo de desterro. Essa vida desregrada, salvo as necessárias diferenças, lembra a vida de Ignacio de Loyola, antes de sua conversão (Jarque I, 1900, p.83). Assim, pretendendo abandonar sua vida desregrada de um quase vagabundo, dirigiu-se ao vice-rei do Peru, solicitando permissão para seguir ao Chile, por dois anos, com o objetivo de lutar contra os Araucano; um grupo considerado indomável. Quando estava a ponto de partir, teve um sonho estranho que o fez desistir dessa empresa. Na segunda tentativa de abandonar a cidade de Lima e, consequentemente, a vida complicada que levava, decidiu ir para o Panamá (Rouillon Arróspide, 2001, p.14).

Acreditamos que considerar a sua formação em uma escola jesuíta e as vicissitudes da orfandade ajuda-nos a entender os motivos que o levaram a querer ardentemente se confessar antes da viagem ao Panamá e a revolta que apresentou diante da negativa dada pelo confessor que ele havia procurado para receber a absolvição. Não se dando por vencido, Ruiz de Montoya foi, durante a noite, ao Colegio Máximo de San Pablo de la Compañía em busca de outro confessor (Rouillon Arróspide, 2001, p.14). Após receber do padre Juan Domínguez a absolvição que tanto procurava, acabou conhecendo o padre Gonzalo Suárez. A convivência e amizade com Suárez fizeram 
que Montoya decidisse retomar os estudos, no ano de 1605. Assim, a sua conversão e a sua decisão de seguir a vida religiosa o levaram, primeiramente, a desejar ingressar na Ordem dos Frades Menores (franciscanos), para depois decidir fazer os Exercícios Espirituais e optar pela Companhia de Jesus (Jarque I, 1900, p.133). Outro aspecto que cabe salientarmos é o espírito aventureiro de Antonio Ruiz de Montoya. Sem dúvida, graças à mística inaciana, característica da vida de Ignácio de Loyola, Montoya viu na Companhia de Jesus a possibilidade de se tornar cavaleiro, não mais do mundo, mas de Cristo. Seu principal propósito era a salvação de almas gentílicas.

Ao recomeçar os seus estudos em linguística-gramática, dialética-lógica e retórica, foi aconselhado pelo seu diretor espiritual (Gonzalo Suárez) a seguir o currículo dos colégios da Companhia de Jesus. Ao terminar os seus estudos, ali mesmo foi admitido para o noviciado (Rouillon Arróspide, 1997, p.29; Tormo Sanz; Román Blanco, 1989, p.75). ${ }^{3}$ Assim, em 21 de novembro de 1606, após ter passado por uma

3 Para tornar-se jesuíta, o candidato passava por uma formação espiritual e intelectual onde deveria responder a chamada de Jesus Cristo, que é um dos momentos chave dos Exercícios Espirituais. Tal chamada apresenta dois níveis de resposta: uma delas é para o candidato que tem "juízo e razão"; a outra é para aqueles que mais queiram se entregar ao "serviço de seu rei eterno e senhor universal" (Salvat, 2002, p.44). A diferença consiste na qualidade da resposta para esses dois níveis de exigência, que estão baseados na generosidade de cada pessoa. Ao que informa Sousa: "A ordem, a organização, a disciplina e o domínio da vontade são outras características de ordem pessoal [...] através de um exercício mental, físico e religioso intensivo, prescrito em detalhes nos Exercícios Espirituais de Loyola. Estes exercícios dão conta dum conhecimento minucioso da natureza humana e das relações recíprocas entre os estados psíquicos e fisiológicos" (Sousa, 2003, p.43). Começa então, ao que salienta Arthur Rabuske, a formação no Noviciado, "desde logo, perfaz o tempo de um biênio, quando outras Congregações Religiosas se contentavam com um único ano. E, somente depois, de se haver colocado esta base religiosa sólida, inicia-se com a formação científica, a qual consiste em três cursos superiores: Humanidades ou Letras Clássicas, Filosofia Eclesiástica e Teologia, segundo o espírito tomista” (Rabuske, 2003, p.77). Com isso, o futuro jesuíta passa por um período de estudos de dez anos, dedicados à Escolástica, onde se estudava o Trivium: lingüística/gramática, dialética/lógica e retórica (para aprender a arte do bem falar e do bem escrever de Quintiliano); e, o Quadrivium: aritmética, geometria, astronomia e música. Após o término, 
profunda conversão, voltou ao Real Colegio de San Martín e iniciou os estudos superiores em Letras Clássicas, Humanidades (Literatura) e Retórica (modo de propor e meios de expressão). Do Real Colegio de San Martín seguiria com a expedição de Diego de Torres Bollo em direção ao Chile. Pois o desejo e a ansiedade de se dedicar à conversão dos índios tornaram possível que Montoya substituísse

o jovem segue os chamados Estudos Superiores, no caso específico, para as já citadas Humanidades ou Letras Clássicas, Filosofia Eclesiástica (obtendo uma formação filosófica aristotélico-tomista) e Teologia, obtendo assim as cinco virtudes intelectuais necessárias, além dos princípios básicos do modelo inaciano: o romanismo (fidelidade incontestável ao papa), a polivalência (além de religiosos, teriam outras aptidões) e o ascetismo (uma vida moral plena). Em meio a esses estudos escolásticos, importantes para uma formação intelectual bastante sólida, os candidatos ainda estudam as vidas exemplares de Ignacio de Loyola e Francisco Javier, entre outros. Pois esses conhecimentos aliavam Teologia e Filosofia, colaborando, desta maneira, com a capacidade intelectual de discernir os fatores positivos ou negativos. Conforme Jesus Maria Sousa, "a tudo isso é preciso acrescentar que os jesuítas cultivavam o savoir-faire do cortesão, as boas maneiras e a habilidade do bom diplomata" (Sousa, 2003, p.44). A partir de tais considerações, segundo o que salienta Rabuske: "Numa boa média, o candidato jesuíta ao sacerdócio atingiu então uma idade próxima dos 31 a 33 anos. E, depois disso, ele volta mais uma vez a um tirocínio chamado de terceira provação, por mais uns dez meses, que recentemente se reduziram a três. A quem causar estranheza esse nome de terceira provação, lembramos que ela fora precedida da primeira provação ou candidatura e da segunda, que é o Noviciado propriamente dito" (Rabuske, 2003, p.77). Havia também, entre os missionários, raros casos de uma formação apressada para o envio às missões. Entre os missionários, encontram-se os coadjutores espirituais que recebiam o mesmo tipo de formação, mas não eram professos, por não terem feito o quarto voto. Havia também o terceiro caso, os coadjutores temporais, que não eram ordenados padres, permanecendo apenas como "irmãos" ao longo de sua vida como jesuíta. Seriam os irmãos, os auxiliares na evangelização, se ocupando das coisas práticas (enfermeiros, cozinheiros, arquitetos etc.). Estas distinções devem ser bem compreendidas, pois constituem a estrutura hierarquizada da Companhia de Jesus. Padres ou irmãos, estes homens de seu tempo, eles eram dotados de um espírito crítico, com uma mentalidade preparada para as dificuldades e os esforços que teriam que enfrentar durante a sua conquista espiritual. Essa "conquista" os levou a ser uma das principais ordens religiosas responsáveis pelas missões nas áreas coloniais da conquista europeia. Desta maneira, fortaleceram a posição da Igreja dentro dos Estados europeus que permaneciam católicos, ou nos que haviam se desvirtuado pelo protestantismo, e levaram o cristianismo para lugares distantes. 
Gabriel Melgar, um noviço doente, no grupo de jesuítas que Diego estava levando às missões (Aguilar, 2002, p.128). Para tal empreitada decidiu refazer os Exercícios Espirituais durante a viagem ao Chile. Acompanhou os seus companheiros para Santiago del Estero, onde permaneceram alguns dias. Prosseguiram para Córdoba de Tucumán, onde receberam orientação do padre Juan de Viana. Seria em Córdoba que Ruiz de Montoya daria prosseguimento aos estudos em Letras Clássicas e Humanidades (Jarque I, 1900, p.163-164). Terminado os estudos, foi ordenado junto a outros três estudantes, na cidade de Santiago del Estero, por decisão do padre Diego de Torres. Com esse mesmo jesuíta foi, ainda naquele ano, à Assunção. Enquanto esperava para entrar nas reducciones do Guairá e juntar-se aos padres José Cataldini e Simon Mascetta, Montoya se dedicou ao estudo da língua guarani, obtendo um grande aperfeiçoamento (Rabuske, 1985, p.47-48).

No ano seguinte, chegou à região do Guairá, onde já haviam sido fundadas as reducciones de Nuestra Señora de Loreto del Pirapó e San Ignacio Miní (Ruiz de Montoya, 1639, f.7v; Chamorro, 2007, p.253; Jaeger, 1957, p.107; Furlong, 1962, p.104). A partir de sua chegada, Montoya passou a auxiliar os seus companheiros nos cuidados espirituais dos guaireños e dos indígenas catequizados. Durante os anos de 1615 até 1622, Ruiz de Montoya se dedicou à construção da igreja da reducción de Nuestra Señora de Loreto. Ao mesmo tempo, seguindo o exemplo dos primeiros jesuítas na província do Paraguay, realizava missões volantes, como meio mais eficaz de entrar em contato com os caciques da região (Aguilar, 2002, p.155; Rabuske, 1985, p.47; Rouillon Arróspide, 2001, p.45).

Foi através dessa estratégia de contanto com diferentes caciques, muitos deles em contraste entre si, que Montoya conseguiu reunir diferentes grupos de indígenas, dando-lhe a possibilidade de observar as distinções existentes entre cada grupo contatado. Servindo-se da sua natural origem criolla, aliada a sua perspicaz capacidade de observação, Montoya captou até mesmo os traços culturais mais sutis dos grupos que contatava. Desta forma, conseguiu relatar nos seus escritos, de maneira minuciosa, não apenas os hábitos, mas também 
as formas de estabelecimento das relações sociais indígenas. E, justamente pela abundância de detalhes captados, esses escritos representam um verdadeiro guia para a compreensão das diferenças entre os grupos indígenas e, sobretudo, para o modo como o missionário jesuíta poderia e deveria se aproximar deles.

Isso o ajudou a ampliar os confins da Civitas Dei, cristianizando e "humanizando" os indígenas (Gasbarro, 2006, p.76; Pompa, 2006, p.117). De consequência, junto aos padres Simón Mascetta, José Cataldini e Cristóbal de Mendoza, entre outros, Montoya tornou-se protagonista nos tempos heroicos (Gálvez, 1995, p.105) das missões feitas pelos jesuítas da província do Paraguay. Todo esse conhecimento fez que Ruiz de Montoya tivesse as condições humanas e pastorais para ser o principal responsável, entre os anos de 1622 e 1628, pelo impulso fundacional de novas reducciones (Rabuske, 1985, p.47), tais como: San Javier; San José; Encarnación; San Miguel; San Pablo; San Antonio; Concepción de Nuestra Señora de los Gualachos ou Concepción de Nuestra Señora de los Guañanas; San Pedro; Los Angeles de Tayaoba, Arcangeles ou Siete Arcangeles; Santo Tomás Apostól ou Tomé; e Jesús Maria (Furlong, 1962, p.107; Aguilar, 2002, p.236-257; Maeder; Gutiérrez, 2009, p.21; Fleck, Bohn Martins; Rodrigues, 2010, p.15). ${ }^{4}$

Entre os anos de 1628 e 1631, ocorreram os ataques às reduções do Guairá. As bandeiras dos paulistas, chefiadas por Antônio Raposo Tavares e Manuel Preto, destruíram as reducciones quase que completamente (escaparam apenas a de Loreto e de San Ignacio) e aprisionaram um grande número de indígenas para o trabalho escravo

4 Ernesto Maeder e Ramón Gutiérrez põem em dúvida a localização e até a existência de algumas reduções. Segundo eles, "de ubicación y existencia incierta fueron las de San Pedro y de Concepción de Gualachos. También corresponden a esa área la ermita de Nuestra Señora de Copacabana y el Tambo de las minas de hierro" (Maeder; Gutiérrez, 2009, p.21). Mas conforme Guillermo Furlong, "en la fundación de todas estas Reducciones intervino o como misionero o como superior de las misiones del Guayra, el Padre Antonio Ruíz de Montoya, pero todas ellas fueron perseguidas y deshechas, en gran parte, por el sanguinario proceder de los paulistas" (Furlong, 1962, p.107). 
nos engenhos de cana-de-açúcar. O envolvimento das autoridades coloniais, tanto espanholas quanto portuguesas, fez com que os jesuítas ficassem abandonados junto aos seus índios, diante da violência dos paulistas. A junta de caciques organizada por Montoya concluiu que a luta armada ou a resistência às invasões era praticamente inútil, uma vez que os paulistas tinham superioridade bélica com o uso dos arcabuzes sobre o "exército" indígena, armado apenas com arcos e flechas (Rabuske, 1985, p.48). A solução foi abandonar o Guairá, escapando dos bandeirantes. Montoya organizou então um plano de fuga, reunindo cerca de 12 mil indígenas. A transmigração ocorreu em 1631, pelo rio Paranapanema, descendo o rio Paraná até as Sete Quedas. Como tática diversiva, Ruiz de Montoya sugeriu, nas proximidades das cataratas, lançar as balsas ou canoas rio abaixo, com o intuito de enganar os bandeirantes. Isto fez que o "povo Israelico" (Ruiz de Montoya, 1639, f.49) seguisse o resto do trajeto a pé até o Uruguai (entre os rios Paraná e Uruguai), onde já existiam reducciones estabelecidas (MCA III, 1969, p.195).

Do grupo que fugiu junto aos missionários restou o número de 4 mil índios, que ajudaram a fundar as novas reducciones de Nuestra Señora de Loreto e San Ignacio del Yabebirí. Neste período de crise, os jesuítas acabaram assumindo um papel de liderança junto aos caciques, ao demonstrarem segurança e firmeza diante das situações de fome e epidemias, que ocorreram após a transmigração (Gadelha, 1985, p.127-128; Aguilar, 2002, p.12; Rebes, 2001, p.36; Rocha Pombo, 1960, p.81). Nos anos seguintes, essas duas reducciones e as outras que foram criadas posteriormente se consolidaram. Quanto às já existentes e às que estavam sendo fundadas nas regiões do Tape e Itatim, ${ }^{5}$ tornaram-se alvo de novas investidas dos bandeirantes.

5 Nesse ponto podem ser incluídas as reducciones do Paraná e Uruguai, as da região do Tape e as do Itatines, a partir das considerações de Ernesto Maeder e Ramón Guitiérrez: "En el Paraná y Uruguay occidental se fundaron los siguientes pueblos: San Ignacio del Paraná o Guazú (1610), Encarnación de Itapúa (1615), Concepción de Nuestra Señora (1620), Corpus Chrsti (1622), Nuestra Señora de los Reyes de Yapeyú (1626) y San Francisco Javier (1629). En los afluentes del alto Paraná se ubicaron Nuestra Señora de la Natividad del Acaray (1624) y Santa 
Neste período, mais especificamente em 1636, Ruiz de Montoya foi nomeado superior de todas las reducciones. Logo tratou de iniciar visitas a cada uma delas. Havia a concreta ameaça de um iminente ataque por parte dos bandeirantes. Todavia, os jesuítas só tomaram uma atitude mais drástica contra tais ameaças após a invasão e a destruição das reducciones do Tape, entre os anos de 1637 e 1638. Novamente, Montoya assumiu a organização da fuga dos indígenas para a região do Paraná e Uruguai, indo contra as ordens do provincial Diego de Boroa, que não concordava com o abandono da região. Uma vez mais, as autoridades coloniais nada fizeram para deter ou punir os bandeirantes. Tentando resolver o problema definitivamente, os jesuítas organizaram a Sexta Congregação Provincial, na qual foi decidido que Antonio Ruiz de Montoya e Francisco Díaz Taño seriam enviados para Madri e Roma, respectivamente, para denunciarem os crimes cometidos pelos bandeirantes e a conivência das autoridades coloniais. Além disto, estavam autorizados a proporem o armamento indígena e a solicitarem o envio de novos missionários (Rouillon Arróspide, 1997, p.279-280; Furlong, 1962, p.125; Rabuske, 1985, p.48; Aguilar, 2002, p.161, 302; Melià, 2008, p.6).

Ruiz de Montoya, por sua vez, prosseguia em Madri, acompanhando o processo movido contra os bandeirantes e promovia a

María la Mayor del Iguazú (1626). [...] Las reducciones formadas al este del río Uruguay, fueron San Nicolás del Piratini (1626), Nuestra Señora de la Candelaria de Caazapamini (1627), Mártires del Caaró (1628), San Carlos del Caapí (1631), Apóstoles Pedro y Pablo, en Aricá (ex Natividad) (1632), Santo Tomé de Ibití (1632) y Nuestra Señora del Acaraguá o del Mbororé. De ubicación incierta resulta San Francisco Javier del Tabitiú, un sitio anterior del San Javier de 1629. Poco después, en camino a las serranias del Tape, se agregaron San Miguel (1632), San José (1633), Santa Ana del Igaí(1633), Jesús Maria del Ibiticaray (1633), San Joaquín (1633) y Santa Teresa del Curití (1633). Las últimas fundaciones fueron San Cristóbal (1634) y Santo Cosme y Damián de Ibitimirí (1634). Incierta es la ubicación de la misión de Nuestra Señora de la Visitación. En la región del Itatín, las misiones sufrieron traslados, concentraciones y divisiones sucesivas. De los cuatro poblados iniciales, Ángeles de Tacuaty, San José de Ycaray, San Benito de Yray y Natividad de Nuestra Señora de Taragüi (1632), se formó uno en Yatebó (1634), para después, entre 1635 y 1647 dividirse en dos: Nuestra Señora de Fe y San Ignacio de Caaguazú” (Maeder; Gutiérrez, 2009, p.21). 
necessidade da defesa armada dos índios. $\mathrm{O}$ armamento chegou às mãos indígenas, antes da resolução final do Conselho das Índias, pois em 1639 e 1640, o governador de Buenos Aires, don Pedro de Lugo y Navarra, concedeu armas aos índios para que estes defendessem as reducciones do Paraná e Uruguai, nas batalhas de Caazapaguazú (1639) e M'bororé (1641). ${ }^{6}$

Durante essa sua estadia na corte, enquanto esperava as resoluções do Conselho das Índias, Montoya escreveu uma breve história dos acontecimentos dos quais ele próprio tinha testemunhado, ou que soube através do relato de outros companheiros, sob o título de Conquista espiritual hecha por los religiosos de la Compañía de Jesus, en las Provincias del Paraguay, Parana, Uruguay y Tape (1639). Neste mesmo período, teve a oportunidade de imprimir três livros dedicados à linguística indígena, intitulados: Tesoro de la lengua guarani (1639), Arte, y vocabulario de la lengua guarani (1640) e Catecismo de la lengua guarani (1640).

De volta ao Vice-Reinado do Peru (1643), com as cédulas reais de aprovação do armamento indígena e auxílio do ex-governador do Paraguai d. Pedro de Lugo y Navarra, Montoya conseguiu

6 As batalhas de Caazapaguazú e M'Bororé foram muito importantes para o fim do ciclo de apresamento indígena por parte dos bandeirantes. Porque têm relevância pelo empenho das lideranças indígenas e dos jesuítas na defesa de suas reducciones. Segundo Kern, dentre os jesuítas, podemos colocar como um dos principais articuladores "o Irmão Domingos de Torres, que participou como 'assistente técnico-militar' na orientação do ainda emergente exército guarani, nos importantes combates de Caaçapaguaçu e M’Bororé (1639 e 1641), o responsável pela orientação e organização da milícia das Reduções no momento mais importante da história do conflito entre jesuítas e bandeirantes. Militar de carreira, tornou-se membro da Companhia e terminou sendo o 'mestre dos índios no manejo das armas de fogo'. Foi ele que feriu com um tiro na coxa o chefe paulista da Bandeira de Caaçapá-guaçu” (Kern, 1982, p.188). Foi nessa mesma Batalha de Caazapaguazú que o padre Diego de Alfaro morreu com um tiro no pescoço. Como essas batalhas não são o tema da presente pesquisa, consideramos oportuno indicar os estudos feitos por: Tormo Sanz; Román Blanco (1989, p.220-225); Kern (1982, p.149-207); Aguilar (2002, p.287-351); dentre outros. O assunto também é tratado na documentação jesuítica: MCA III (1969, p.303-314, 329-334, 345-368). 
rapidamente que o vice-rei a promulgasse (Furlong, 1962, p.126). Ainda em Lima, Montoya envolveu-se na defesa da Companhia de Jesus diante das acusações feitas pelo bispo de Assunção, dom frei Bernardino de Cárdenas, ${ }^{7}$ questão esta que se prolongou pelos seus seis últimos anos de vida. Na sua estadia em Lima, o missionário dedicou parte de seu tempo aos cuidados espirituais dos escravos negros, sem deixar também de continuar a ensinar a língua guarani na Universidad San Martín, dar orientação espiritual e escrever.

Antes de sua morte, em 1652, ainda escreveria o manuscrito Sílex del Divino amor y rapto activo del aníma, en la memoría, entendímínto y voluntad quese emprende el Divino fuego mediante un acto de Fé(1991 [c.1650]). É neste livro que Montoya mencionaria os ensinamentos místicos que recebeu do índio Ignacio Piraycí (Melià Litteres, 2010, p.72). Tais ensinamentos eram voltados ao jovem jesuíta Francisco del Castillo toda a sua experiência contemplativa, suas renúncias e dedicação ao apostolado de missionário. Deixou ainda um livro em forma de manuscrito: Apología en defensa de la doctrina cristiana (2008 [c.1651]).

Ao longo de sua vida, escreveu muito e narrou detalhadamente os acontecimentos vivenciados por ele, pelos seus irmãos em Cristo e pelos seus "filhos" indígenas, na Província do Guairá, através da

7 O conflito entre o frei Bernardino de Cárdenas e a Companhia de Jesus, no Paraguai, iniciou após a nomeação de Cárdenas como bispo da diocese de Assunção por Felipe IV. Nas primeiras cartas enviadas pelo bispo ao rei, o primeiro demonstrava simpatia pela Companhia, contudo, após se interessar por uma propriedade na cidade de Assunção pertencente aos jesuítas, ameaçou-os de expulsão da Província do Paraguai. Para obter êxito na empreitada, aproveitou a nomeação de Diego Escobar y Osório, como novo governador do Paraguai, para influenciá-lo contra os jesuítas. As inúmeras acusações, feitas por Cárdenas contra os jesuítas, incluiriam o uso herético de palavras escandalosas, oriundas de um catecismo todo escrito em guarani. Seguindo com o seu plano, aproveitou a morte de Escobar y Osório, para assumir o governo da cidade. Este fato perdurou até a nomeação de Sebastián de Léon como governador interino de Assunção, no mesmo ano da morte do governador, 1649. Como governante, Don Léon restabeleceu a ordem, fazendo várias reparações aos danos sofridos pelos jesuítas e ordenou que o bispo de Cárdenas fosse exilado à Chuquisaca, local onde o bispo faleceu em 1666 (Aguilar, 2002, p.167-169; Melià, 2008, p.10-11). 
sua visão e percepção de mundo. Em suas narrativas representava não apenas a si mesmo, mas aos outros, principalmente os grandes personagens da sua "reconquista espiritual": índios, bandeirantes e jesuítas.

Ampliou os confins da "Cidade de Deus" até uma das regiões mais isoladas da Província Jesuítica do Paraguai (o Guairá), mostrando que essa Civitas Dei era aberta a todas as gentes, principalmente as que apresentavam "não poucos problemas teológicos para o trabalho de evangelização" (Gasbarro, 2006, p.79). Como no livro de Santo Agostinho, a Cidade de Deus se opõe à do demônio e seus anjos. Em outras palavras, os verdadeiros cristãos (jesuítas e indígenas catequizados) combateram os emissários do demônio (os pajés) e os seus agentes, os mouros (os bandeirantes).

\section{A escrita montoyana}

O universo montoyano é rico em imagens, sons e cores. Em sua narrativa, a variedade da selva paraguaiense são fontes inesgotáveis de símbolos que representavam o mundo maravilhoso criado por Deus. Há também menções aos métodos de navegação da época, com a utilização de bússolas, velas e os astros. Ensina a utilidade de uma luneta para a supressão das distâncias; algumas lições de astronomia (medidas do centro até a superfície da Terra, localização de cada planeta através do sistema da Grécia antiga) e os seus onze céus. ${ }^{8}$ A diversidade de assuntos narrados seria oriunda de uma observação atenta

8 "Revuelve la grandeza de la tierra com la vista. Mide sus espacios, cuales los doctos matemáticos y geógrafos, desde el punto y centro hasta la planicie que pisas, miden 1,164 leguas y media; de diámetro, 2,349; de circuito, 7,500. Desde esta superficie hasta el cielo lunar, miden 35,128. El primer cielo, que es el de la Luna, tiene 66,336 leguas. El segundo, que es el de Mercurio tiene 222,086 leguas. El tercero, que es el Sol, tiene 216,666 leguas y 2 millas. El quinto, que es el de Marte tiene 1,6000'588,000 leguas. El sexto, que es el de Júpiter, tiene 1,100'979,500 leguas. El séptimo, de Saturno tiene 1,200’360,827 leguas y una milla. Cada leguas de tres millas y cada milla de dos mil pasos. El octavo cielo no se puede medir por no poder 
e memória fiel aos fatos transcorridos em diferentes regiões e mares (Rouillon Arróspide, 1991, p.lxvi-lxviii). Nos documentos e livros, percebemos a erudição adquirida por Ruiz de Montoya ao longo dos anos, e como este crescimento influenciou na sua escrita. As três formas de escrita convergem nos relatos, nas cartas e relaciones, na narrativa da Conquista e no misticismo do Sílex.

Montoya era muito direto nas suas cartas e relaciones, não medindo palavras para descrever determinadas situações ou denominações que lhe eram apresentadas. No entanto, a insistência dele em transformar esses relatos em um livro acerca da história heroica da Companhia de Jesus na Província Jesuítica do Paraguai fez que este corto estilo, presente até então na sua escrita, se tornasse refinado. $\mathrm{Na}$ Conquista, notamos o esforço e a aplicação em melhorar o seu estilo de discurso. Para tanto, procurou, na literatura espanhola, autores que o "ajudassem" a escrever. As frases, antes concisas, passam a ter uma força impactante em volteios idiomáticos.

Todavia, a diferença maior entre as formas de escrita histórico-literária montoyana transparece quando observamos os mesmos assuntos tratados na Conquista sendo retomados no Sílex. Se na Conquista a escrita deveria agradar aos superiores, no Sílex, a exigência passou a ser interior. A escrita montoyana foi de um tom mais informal (Conquista) para uma forma mais séria, intensa e profunda (Silex). Esse amadurecimento pessoal e intelectual transparece quando o missionário trata sobre a presença de Deus através da filosofia tardo-medieval, servindo-se argumentum ad verecundiam ou argumentum magister dixit (argumento da autoridade), para embasar o seu ensino espiritual. Ao tratar da presença de Deus, as palavras faltam, pois elas não obecedem àquele que as escreve. Essa mudança de tema e a distância entre os anos de escrita de cada livro faz que as diferenças sejam vertiginosas em versões de um mesmo assunto

coger ángulos a las estrellas, perlo colígese ser más su corpulencia que la de los otros. El noveno es cristalino y no tiene estrellas; y así no es mensurable. El décimo es el primer móvil, que arrebata y mueve los demás y los hace volver en venticuatro horas. El onceno y último de toda cosa criada es inmóvil, casa de Dios y es inmendurable" (Ruiz de Montoya, 1991, p.15-16). 
(Rouillon Arróspide, 1991, p.lxxv-lxxviii). Os toques de ironia e os paradoxos continuaram; contudo, foram perdendo a sua frequência dentro das frases.

\section{O Guairá como palco de representações montoyanas}

O Guairá deixou de ser um espaço físico e geográfico para se tornar um importante cenário da história montoyana. Neste lugar do passado, ocorreria a batalha cristã, que povoava o pensamento europeu desde muito tempo: a disputa pelo território entre as forças celestes e as demoníacas (o bem contra o mal); a extirpação do joio, semeado entre o trigo. O território guaireño deixou de ser um espaço físico. Passou a formar um cenário no qual imagens e acontecimentos, projetados na mente de Montoya, comporiam a sua narrativa. Desta forma, Montoya cria uma representação de um cenário guaireño que, formulado e reestruturado, através das suas lembranças, faz dos índios (menos marcadamente que os demais), jesuítas, criollos e bandeirantes personagens quase maniqueístas ${ }^{9}$ numa narrativa feita pelos jesuítas acerca da sua conquista espiritual.

Para Michel de Certeau, a escrita da história durante o século XVII e a questão da hermenêutica do outro, a partir da visão, daquilo que é visto e/ ou escutado (Certeau, 2000, p.211) são dois temas caros que devem ser sempre analisados. O olhar europeizado, como eram os relatos feitos pelos viajantes e pelos missionários, apresenta uma representação cultural,,$^{10}$ uma "escrita em espelho" (Certeau, 2000, p.48),

9 A ideia de maniqueísmo vem da leitura do livro das Confissões de Santo Agostinho, autor lido por Montoya, não somente durante a juventude, mas também no tempo em que permaneceu na corte de Madri.

10 O conceito de representação cultural é baseado em Roger Chartier. Compreendemos as representações como uma presença que aponta para algo/alguém ausente, prevalecendo uma relação entre exposição e ocultamento. Com isso, percebe-se que as representações são uma das formas de retratar as relações travadas entre jesuítas e indígenas durante a fundação das primeiras reducciones. 
na qual medos e anseios são projetados no outro. Com isso, os primeiros colonizadores projetaram na América tudo aquilo que conheciam, fazendo dela uma versão adaptada da Europa. No caso que estamos estudando na presente dissertação, esse olhar sobre o outro está baseado na visão de mundo de um criollo, educado numa cultura europeia na América espanhola, e como ele retratou as relações travadas entre jesuítas, grupo do qual fazia parte, e indígenas, durante a fundação das primeiras reducciones.

Roger Chartier, nos seus estudos, ressignifica o conceito sociológico de representação, em seu livro História cultural, como categoria de representação individual. Tais considerações ocasionaram uma série de críticas, que afirmavam que a História havia se tornado uma literatura do passado. ${ }^{11}$ Por isso, no final dos anos de 1990, François Hartog (1999) retoma esse conceito, inserindo-o em sua particularidade textual, através da visão de mundo do autor que está escrevendo. Tanto Chartier, quanto Hartog enfatizam que as representações oriundas da percepção individual não podem ser percebidas como mentiras.

Dessa forma, para explicar o conceito de representação, Chartier partiu do conceito original de representação coletiva, que se articularia a partir de

três modalidades da relação com o mundo social: primeiro, o trabalho de classificação e de recorte que produz as configurações intelectuais múltiplas pelas quais a realidade é contraditoriamente construída pelos diferentes grupos que compõem uma sociedade; em seguida, as práticas que visam a fazer reconhecer uma identidade social, a exibir uma maneira própria de estar no mundo, a significar simbolicamente um estatuto e uma posição; enfim, as formas institucionalizadas e objetivadas graças às quais "representantes" (instâncias coletivas ou indivíduos singulares) marcam de modo visível e perpetuado a existência do grupo, da comunidade, da classe. (Chartier, 1990, p.73)

11 A questão das críticas feitas ao conceito de representação pode ser observada no artigo de Rafael Guarato, intitulado Por uma compreensão do conceito de representação (2013). 
O conceito deve ser considerado como o que permite ver uma "coisa ausente, o que supõe uma distinção radical entre aquilo que representa e aquilo que é representado” (Chartier, 1990, p.20). Representar é, fundamentalmente, estar no lugar de; é tornar presente aquilo que está ausente. A ideia central é a da substituição, que recoloca uma ausência e torna sensível uma presença. Sendo assim, o significado central do conceito de representação é de trazer para o presente o ausente vivido e, dessa forma, poder interpretá-lo. O estabelecimento de representações, a partir das afirmações de Durkheim, não pode ser considerado como pacífico, tampouco consensual. As representações tendem a apresentar características conflituosas, pelas quais cada grupo ou indivíduo compreende a si mesmo e ao outro de uma determinada forma. Pois a "construção consciente de um espírito individual opõe-se, passo a passo, à mentalidade sempre coletiva que rege as representações e juízos dos sujeitos sociais, sem que estes o saibam" (Chartier, 1990, p.41).

Portanto, a legitimação de uma identidade passa pela desqualificação de outra. A representação pressuporia uma separação entre imaginário e mundo material. Construir-se-ia, na vida cotidiana, nas negociações e nos conflitos diários. Tratando-se de uma narrativa, o texto se constitui de formulações feitas acerca das vivências do autor, do relato de outros personagens, que presenciaram os fatos, e de informações que foram dadas àquele que escreve. As representações acabariam criando uma perspectiva de que haveria uma trama envolvendo dois grupos distintos: nós e os outros. Contudo, dentro desses grupos, as particularidades e as percepções individuais se sobressaem. Consequentemente, Ruiz de Montoya ao escrever a história desses grupos se colocou na posição de um verdadeiro transgressor dessa fronteira. Mesmo que a análise dos outros fosse inexoravelmente interligada aos pressupostos que formariam o nós como um todo, ela poderia ser elaborada de uma maneira que atenuasse essas diferenças (Hartog, 1999, p.367).

A narrativa torna-se, passo a passo, uma maneira de reconstrução de lembranças dos envolvidos, através de um jogo de persuasão, dentro do processo narrado (Hartog, 1999, p.302). A isto, Chartier 
afirma ser "a história das ideias reposta numa exploração de conjunto mental coletivo, [pertencente] à consciência do grupo social de que fazem parte" (Chartier, 1990, p.43-47), sendo que a relação entre práticas e representações, segundo ele, podem ser mutáveis. Tanto as práticas podem ser indeterminadas, como as representações podem ser modificadas. Nas inferências do próprio autor, as noções de práticas e representações - as quais são primordiais para o historiador da cultura - são explicitadas da seguinte maneira:

De acordo com esse horizonte teórico, a Cultura (ou as mais diversas formações culturais) poderia ser examinada no âmbito produzido pela relação interativa entre estes dois polos. Tanto os objetos culturais seriam produzidos entre práticas e representações, como os sujeitos produtores e receptores de cultura circulariam entre esses dois polos, que de certo modo corresponderiam respectivamente aos "modos de fazer" e aos "modos de ver". (Chartier, 1990, p.76)

Desta forma, a narrativa foi uma maneira de reconstruir as vivências dos envolvidos dentro do processo narrado.

A descrição [...] consiste bem em fazer-nos ver e em fazer saber; [... ] o que importa é a presença e a ausência de marcas fortes de enunciação. De fato, segundo ela, se organize ou não em torno de um "eu vi” inicial, o efeito de estranheza que produz varia bastante. (Hartog, 1999, p.273)

Ou seja, a escrita montoyana giraria em torno dos polos de quem viu e ouviu, que constituiriam as suas enunciações. Os enunciados operariam como uma forma de ritmar a narrativa, impulsionando ou atenuando aquilo que estava sendo relatado. Ruiz de Montoya descreve os fatos de uma forma inteligivel aos espanhóis e aos criollos.

Segundo Pierre Nora, essa estruturação se deve à "adequação da história e da memória [...] [Pois] a história vivida e a operação intelectual que a tornam inteligível [formam] o movimento que nos transporta [e] é da mesma natureza que aquele que o representa para 
nós" (Nora, 1993, p.8). ${ }^{12}$ O que se pode afirmar é que, ao lermos as narrativas escritas por Antonio Ruiz de Montoya, nos deparamos com uma forte presença da memória afetiva e mágica. O mágico está relacionado ao fato de que o universo percebido e descrito pelo jesuíta é maravilhoso e perfeito, pois é uma criação divina. O mundo, através de uma perspectiva fantástica, dá a possibilidade de se deparar com um novo Éden e com sujeitos de "alma pura”, para usar uma expressão cara a José de Anchieta. A percepção montoyana da necessidade de salvação dessas criaturas, sob influência demoníaca dos pajés, faz que o relato desse missionário seja quase uma narrativa de tipo literária.

Neste universo divino, o sobrenatural é constante e explica os sucessos e os fracassos ocorridos em meio à selva. A narrativa se "alimenta de lembranças vagas, telescópicas [...] particulares ou simbólicas, sensível a todas as transferências, cenas, censuras ou projeções" (ibid., 1993, p.9). Mesmo com acesso a uma enorme quantidade de documentos para a escritura da Conquista espiritual, percebemos que, em boa parte do livro, a memória do seu autor é latente. $\mathrm{O}$ mesmo ocorre anos depois, com a escritura de Sílex del divino amor. A memória faz que as representações, que tornam presente o ausente (Chartier, 1990, p.41), sofram mudanças e deformações, conforme os fatos se tornam cada vez mais longínquos; no nosso caso, tornando a história da conquista espiritual dos indígenas uma representação do passado. Será através dessas projeções simbólicas que os indígenas serão retratados como "infiéis" ou "espirituais".

Desta maneira, a representação imbuída das transformações memorialísticas não demonstra mais uma realidade presente e constituída (Chartier, 2004, p.19). Todavia, tais representações contribuem com a escrita de uma história verídica, a partir do testemunho do seu autor que vivenciou os fatos. Consequentemente, a significação interpretativa do mundo que o cerca, sendo verdades em si mesmas, com

12 O conceito de memória também foi discutido dentre outros autores por: Hobsbawm; Ranger (2002); Le Goff (1991); Halbwachs (1992); López Austin (1985); Borja Gómez (2002). Todavia, para o objetivo deste artigo, as posições de Chartier e Nora são suficientes para a discussão historiográfica que aqui propomos. 
as suas intencionalidades na hora de escrita e com a reapropriação daquilo que é e foi real (Chartier, 1990, p.59).

A história montoyana deve ser analisada a partir da visão de mundo do seu autor. Ruiz de Montoya não via o mundo como teatro ou representação. As representações surgem com a leitura que fazemos sobre a sua percepção dos acontecimentos e a maneira com que relata minuciosamente aquilo ou aqueles que o cercavam (ibid., p.47). Montoya descreveu personagens de características muito ricas. As formas de percebê-las e relatá-las mudavam pelas suas decisões que acarretaram alterações nos rumos da história na qual estavam inseridas. A história montoyana não foi isenta de julgamentos sobre aqueles que eram percebidos como os outros e suas culturas, descrevendo alguns costumes e atitudes como demoníacas. Da mesma maneira, relatou sobre os espaços que percorria e as dificuldades enfrentadas na travessia dos acidentes geográficos. Tais observações possibilitaram-lhe encontrar uma forma eficaz de traduzir a realidade indígena para os europeus.

Os protagonistas dividem-se entre índios espirituais (o "bom trigo" da seara evangélica) e índios rebeldes (o "joio" entre o trigo semeado, sobretudo os pajés). Desta forma, segundo Chartier, dentro da narrativa surgem as tentativas

para decifrar de outro modo as sociedades, penetrando nas meadas das relações e tensões que as constituem a partir de um ponto de entrada particular [...] e considerando não haver prática ou estrutura que seja produzida pelas representações, contraditórias e em confronto, pelas quais os indivíduos e os grupos dão sentido ao mundo que é o deles. (ibid., p.177)

Na visão de mundo montoyana, portanto, os indígenas estão separados por estas duas categorias antagônicas: o "receptivo" à doutrina cristã e o "não receptivo"; o "fiel e obediente" às normas de conduta cristã e os "rebeldes". Tais categorias podem ser observadas como uma estratégia para atingir o maior número de leitores possível para a narrativa que estava sendo feita, persuadindo, através da arte da 
retórica, aqueles que lessem o relato verídico e, logo, se tornassem apoiadores da Companhia de Jesus na ampliação e defesa da conquista das almas que estava sendo feita (Hansen, 2013). ${ }^{13}$

Sendo assim, a rebeldia do indígena refratário ao Evangelho se deve sobretudo à sua não aceitação da presença e atuação catequética dos jesuítas, uma vez que tal presença significava a "morte" da sua cultura ancestral. Tal "rebeldia" será lida pelos missionários, em especial por Montoya, como uma conduta moral e civil "má". Tudo isto já foi objeto de inúmeras pesquisas, razão pela qual não repetiremos o que já foi estudado. Mais profícuo será analisar, mesmo que brevemente, os únicos três casos em que os indígenas deixam de pertencer a uma massa anônima e passam a adquirir uma identidade própria, como situações de índios exemplares (fiéis e espirituais). Esses três exemplos, além de representarem o modelo de indígena convertido, demonstram como cada grupo indígena recebeu o cristianismo.

\section{Os índios exemplares: as representações montoyanas}

As narrativas montoyanas nos apresentam dados e interpretações importantes sobre o cotidiano e os costumes dos indígenas. Como observador arguto, Montoya procurou descrever detalhadamente o que percebia a sua volta. A escrita montoyana, portanto, não descreve homens como hoje eles são estudados pela Antropologia. Sua escritura apresenta a percepção de um indivíduo que se sobressai em alguns aspectos em relação ao grupo ao qual pertence, a Companhia de Jesus, bem como sobre os outros grupos de indivíduos envolvidos no processo histórico.

Para converter os indígenas e, principalmente, fazê-los abandonar os antigos vícios foi necessário que a catequese abrangesse a

13 Um acurado estudo sobre a utilização da retórica na escrita da Companhia de Jesus pode ser visto em várias publicações de João Adolfo Hansen acerca do tema. 
diversidade cultural dessas tribos. Mais do que uma simples tradução a ortodoxia religiosa cristã encontraria na figura do outro, as diferenças que formavam a humanidade única, defendida pelos religiosos. Para tanto, foi necessário elaborar um catecismo que atendesse às necessidades dos missionários, para doutrinar os rudes e os selvagens.

A tradução para o guarani, segundo a concepção de Ruiz de Montoya, representava o reconhecimento da capacidade dos índios de compreender o Evangelho. Para tanto, procurou sistematizar a linguística indígena para melhor converter as almas e conquistar cada vez mais tribos de gentios (Monteiro, 2011, p.6).

Palavras que teriam o seu uso mais frequente nos sermões e nos ensinamentos foram traduzidas através de similaridade, no sentido que lhes era atribuído tanto no castellano, quando no guarani. A criação desses neologismos procurava fortalecer a relação missional entre os jesuítas e as tribos. Transformando essas palavras em representações que operariam como instrumentos teológicos, isto é, categorias de adaptação semântica que se adaptariam ao mundo indígena. Essa semantização adotada selecionava vocábulos que mais se aproximassem do conceito a ser traduzido para o discurso dos índios (Chamorro, 2009, p.113).

Tendo êxito no apostolado, os missionários, principalmente, Montoya, relatavam que os indígenas davam "muestras que ha de ser muy lustrosa en Christandad” (Ruiz De Montoya, 1639, f.79v). Entretanto, nos primeiros anos de missionação, os índios demonstravam pequenos desvios na sua conversão. A permanência de alguns rituais de enterramento, culto aos ossos de xamãs e a poligamia trouxeram problemas aos missionários que tentavam encontrar meios para que essas práticas fossem abandonadas definitivamente. Nesta luta contra os vícios, os resultados iam desde o arrependimento dos envolvidos ao martírio de alguns jesuítas.

Dentro dos pueblos que constituíam as reducciones, as narrativas sobre as conversões e curas milagrosas, ressurreições com discursos sobre a outra vida e manifestações sobrenaturais foram abundantes. O relato montoyano apresentava como característica a ênfase de exemplificar a nova vida obtida por aqueles que acreditavam 
no poder de Deus (Léon-Dufour, 1974, p.20). Para embasar as suas afirmações, Montoya exemplificaria com a construção de narrativas que tratassem sobre as conversões que ocorriam entre os índios que serviriam como exemplo do êxito das missões.

Neste contexto, indígenas e jesuítas acabaram se envolvendo em uma trama de símbolos e interpretações oriundas de duas culturas distintas. É neste ponto que podemos obter as informações etnológicas sobre os dois grupos envolvidos e as suas respectivas especificidades tribais. Isto não significa que o nativo que emerge dessa narrativa montoyana seja um índio antropológico. Trata-se, parafraseando Meliá, de um "índio de papel”, istoé, de um indígena descrito a partir do ponto de vista do missionário, de como o percebeu e o interpretou na sua cultura.

Foi a partir desta visão que a história do índio colonial se estruturou. Montoya, enquanto criollo e jesuíta, deveria cristianizar e civilizar ao modo europeu. Deveria observar, descrever e perceber a melhor maneira de catequizar. Isso o fez representar o indígena como alguém de alma boa e constantemente tentado pelas ações demoníacas. Contudo, pela sua religiosidade, esse indígena tinha uma predisposição à recepção das verdades evangélicas (Berto, 2006, p.27).

Dentre os inúmeros nomes de índios citados ao longo das narrativas sobre como ocorreu a conquista espiritual dos indígenas guaireños, vamos destacar três nomes que representam bem as figuras dos índios exemplares: Roque Maracanan (guarani), Cohen (gualacho), Ignacio de Piraycí (guarani). As representações que definiriam bem esse "tipo" de índio estão presentes nos livros Conquista espiritual (1639) e Sílex del divino (1991 [c.1650]). As representações sobre esses indígenas são curtas, pois servem como modelos de verdadeira conversão. Nos livros Conquista espiritual, Sílex, bem como nas cartas ânuas, o nome desses caciques e as suas conversões e atitudes se repetem. Sabemos que muitos outros indígenas também serviriam de modelo, contudo sem que os seus nomes fossem divulgados.

O cacique da reducción de San Ignacio, Roque Maracanan, é um dos indígenas que merece longos elogios no relato de Conquista espiritual. Maracanan, segundo salienta Montoya, seria "un honrado 
Cazique, deseoso de oir las cosas de su salvacion" (Ruiz de Montoya, 1639, f.12v). Após ouvir um chamado divino (durante seu sonho) para que obedecesse ao padre, esse cacique levou o seu povo para a reducción. Maracanan, "a quien toda la tierra venerava” (ibid., f.15r), tornava-se um dos exemplos de índio modelo. A ida para as proximidades de San Ignacio fez que ele assumisse uma aliança com os jesuítas. Desta maneira, quando iniciaram as ameaças de assassinato dos missionários, por parte de Miguel Artiguaye (cacique de Loreto), Maracanan se coloca na posição de defensor dos padres e das reducciones. Essa atitude acirrou ainda mais o confronto entre ele e Artiguaye. Em seu discurso de defesa, Maracanan, "mostrandose [...] muy bien dispuesto", disse aos outros indígenas que "la desaverguença" de Miguel, ele mesmo castigaria (ibid., f.17r-17v). O que percebemos na representação de Roque Maracanan é a aliança estabelecida com alguns caciques para que a missão fosse possível. Por um lado, podemos ver que as relações sociais estabelecidas, dentro de termos próprios ao contexto em que foram criadas, transparecem as individualidades dos personagens e a pluralidade em que estavam inseridos. Ao aceitar a presença dos padres e ao assumir uma posição de defensor das reducciones, Maracanan assume também o papel de exemplo para outros indígenas, os quais deveriam seguir o mesmo caminho do honrado cacique. A sua figura, além de ser um exemplo para os demais membros do seu grupo, é também utilizada para representar o modo como o missionário deveria estabelecer o contato com um grupo guarani. Suas reações diante da possibilidade de salvação o inserem em uma proposta de discurso edificante. A voz do indígena transforma o discurso do missionário, de modo que as suas operações e sistemas de ação façam com que ele deixe de ser o autor da sua história, mas se insira dentro de uma perspectiva na qual se torna o ator de quem narra a sua história (Certeau, 1998, p.38).

A figura do índio Ignacio Piraycí, descrito ao longo do Sílex, ilustra particularmente bem a categoria de "índio espiritual". Este, segundo o relato de Montoya, ensinou os caminhos da mística e da contemplação ao modo indígena para o missionário. A lógica da direção espiritual se inverte: o orientando se converte em orientador e 
vice-versa; aquele que devia ser o orientado ensina àquele que seria o mestre. Apesar da grande experiência espiritual de Montoya, é com o diálogo espiritual com o índio Piraycí que o missionário conseguirá integrar a dinâmica dos exercícios espirituais inaciano da "contemplatio ad amorem" (isto é, de ver Deus em todas as coisas e todas as coisas em Deus) na sua vida cotidiana, percebendo Deus sempre e em tudo. Em um momento de crise espiritual, ao se confrontar com o índio Piraycí, Montoya recebe a seguinte resposta:

Yo, Padre, luego que despierto por la mañanita, creo que Dios está allípresente, testigo de todo lo que hago; con este pensamiento me levanto y hago levantar á mi familia, y todos juntos, guiando yo el coro, rezamos todas las oraciones. Acudo luego á oir misa, continuando la memoria que llevo à Dios siempre á mi lado. Con esta fe y consideración asisto á aquel santo sacrificio, con ella vuelvo á mi casa, convoco otra vez mi gente para que vayamos á trabajar. En el camino me acuerdo que Dios me acompaña; lo mismo hago en mi trabajo, sin perderlo jamás de vista, porque he adquirido tal hábito que aunque quisiese no podría olvidarlo. Acabada mi tarea, vuélvome al pueblo y siempre pensando que Dios viene conmigo. Primero voy á la iglesia que á mi casa; en aquella con singular afecto le adoro y le doy gracias por los beneficios que me hace y por el cuidado que tiene de sustentarme; con esto vuelvo á mi casa y duermo sin cuidado, persuadido que Dios me está guardando el sueño. (Jarque IV, 1900, p.151-152)

Mais tarde, em seus escritos, Montoya repassará a experiência espiritual do índio Piraycí ao seu discípulo Francisco del Castillo, que ilustra muito bem a mesma experiência inaciana da última meditação dos Exercícios Espirituais de Ignácio de Loyola (contemplatio ad amorem).

No relato de Piraycí observa-se a inversão de papeis: o índio que se torna mestre de vida espiritual e o jesuíta que se faz discípulo espiritual. Por isso, Piraycí torna-se o "modelo" de índio convertido. Após seu batizado, passa a frequentar diariamente as missas, a dedicar-se aos estudos da lei divina, chegando inclusive a recitar o catecismo à 
memoria. Mais ainda, nas entrelinhas do seu testemunho registrado por Montoya, percebe-se uma fé inabalável na pessoa de Cristo, além da experiência da constante presença de Deus na sua vida cotidiana. Experiência esta que nos lembra da mesma forma a existência de Ignacio de Loyola.

O modelo de índio obtido com Piraycí serve não apenas para a função de registro jesuítica sobre o amadurecimento espiritual de outrem, mas está relacionado às variantes de um discurso onde há o relato daquele que experimentou e que, consequentemente, divulga a experiência mística que vivenciou. Nesta descrição, se evidenciam as interpretações sobre a percepção de Deus entre duas culturas distintas. Índio e jesuíta, nesta representação, tornam-se os verdadeiros filhos de Adão e estabelecem um diálogo espiritual até então jamais previsto.

No caso dos Gualacho, o "índio fiél” aparece representado na figura do cacique Cohen, que ao ser informado da chegada dos padres ao seu pueblo, deu "mui grandes muestras de amor" (MCA I, 1951, p.295). Essa atitude demonstraria e retrataria o exemplo da predisposição indígena para a recepção do Evangelho em suas aldeias. Cohen auxiliou os padres a iniciarem o processo de conversão dos Gualacho, demonstrando que o sucesso ou fracasso da missão jesuítica dependia da aceitação ou não dos indígenas. Contudo, Montoya ressalta que a bondade de Cohen sobressai a todos os outros indígenas do grupo. Porque a vida moral desse cacique e a sua vida religiosa, na visão de mundo do jesuíta, eram oriundas de uma mesma fonte: Deus (Certeau, 2000, p.136-137).

Esse cacique de alma nobre, segundo a narração de Montoya, apresentava todas as características de um bom cristão; sobretudo aquela de prestar serviços em auxílio da difusão da Boa-Nova entre o seu povo. Dentre as demonstrações de uma verdadeira conversão e piedade cristã, os indígenas da aldeia de Cohen aceitavam conviver com os índios do cacique Tayaoba, encerrando um período de guerra entre esses dois grupos. Cohen possibilita a Montoya criar uma representação onde se estabelece um "contrato social” entre os dois lados, que substitui as generalidades edificantes. Esse indígena, através da 
percepção do jesuíta, antes mesmo de receber o Evangelho já era um cristão. Ao aceitar e auxiliar na propagação do catecismo, apenas enfatizava a sua fé preexistente.

\section{Considerações finais}

O Guairá, na perspectiva de Antonio Ruiz de Montoya, ganha o prisma de cenário histórico e literário. Os indígenas não são apenas figuras antropológicas. São também, parafraseando Meliá, "índios de papel”, índios literários, descritos a partir de categorias teológicas: receptáculos naturais do Evangelho.

Os Guarani, representados por Maracanan e Piraycí, encarnavam o povo, cuja principal característica era a de possuir uma língua que melhor definia o conceito do Deus cristão. Contudo, alguns dos seus hábitos eram condenáveis, como a poligamia e a antropofagia, o que acarretou não poucas incompreensões e choques culturais, sobretudo entre os missionários com os pajés. A figura do pajé podia ser ambígua. O pajé, quando exercia a sua função de guia espiritual e místico na sua tribo (através dos ritos ancestrais), aos olhos do missionário, era identificado como agente do demônio. Todavia, essa mesma liderança podia ser percebida como prova de religiosidade entre os Guarani e, por conseguinte, que estes podiam receber o cristianismo. Ao contrário dos Guarani, os Gualacho apresentavam maior disposição para receber a Boa-Nova. Esses indígenas, na figura de Cohen, são descritos como "boa gente", respeitadora do matrimônio monogâmico e que tinham o hábito de andar vestido. O problema, entre os jesuítas em relação aos Galacho, estava com as práticas cristãs de sepultamento. Enquanto os Guarani aceitavam a sepultura do corpo na terra escavada, conforme o costume ibérico, os Gualacho, que tinham por hábito a cremação dos seus defuntos, rejeitavam com determinação qualquer prática fúnebre de sepultamento cristão.

Esses indígenas são como Ruiz de Montoya os vê e os descreve, separando-os pelas suas atitudes e decisões, especialmente em relação à aceitação ou recusa da Boa-Nova. A narrativa não é de todo 
completa, é feita com o uso da memória e das ideias do seu autor. Sendo criollo, Montoya acabava percebendo os indígenas (Guarani ou Gualacho) como homens dignos de respeito e direitos. Sendo jesuíta, formado segundo os princípios teológicos da época, a sua forma mentis fazia que compreendesse as diferenças fundamentais entre os grupos indígenas com os quais tinha contato. Daí a diferença do seu agir, segundo o grupo que contatava.

O que fica determinante é que o criollo não se distingue do jesuíta, mas ambos se complementam. E essa unidade caraterial fará de Montoya um ardente defensor dos direitos dos indígenas das reducciones, reivindicando na corte madrilena até mesmo o direito à defesa armada dos seus filhos espirituais.

\section{Referências bibliográficas}

AGUILAR, J. C. Conquista espiritual: a história da evangelização na Província Guairá na obra de Antônio Ruiz de Montoya, S.I. (1585-1652). Roma: Pontificia Università Gregoriana, 2002.

BAPTISTA, J. T. Jesuitas e guarani na Pastoral do Medo: variáveis do discurso missionário sobre a natureza (1610-1650), 2004. 149f. Dissertação (Mestrado em História) - Programa de Pós-Graduação em História. Pontifícia Universidade Católica do Rio Grande do Sul, Porto Alegre, 2004.

Fomes, pestes e guerras: dinâmicas dos povoados missionais em tempos de crise (1610-1750). 381f. Tese (Doutorado em História) - Programa de Pós-Graduação em História. Pontifícia Universidade Católica do Rio Grande do Sul, Porto Alegre, 2007.

O temporal: sociedades e espaços missionais. São Miguel das Missões: Museu das Missões, 2009.

Oeterno: crenças e práticas missionais. São Miguel das Missões: Museu das Missões, 2009.

BARCELOS, A. H. F. Espaço E arqueologia nas missões jesuíticas: o caso de São João Batista. Porto Alegre: EDIPUCRS, 2000.

BORJA GÓMEZ, J. Los indios medievales de fray Pedro de Aguado. Construcción del idólatra y escritura de la historia en una crónica del siglo XVI. Bogotá: Centro Editorial Javeriano/Pontifica Universidad Javeriana/Instituto 
Colombiano de Antropología e Historia, Instituto Colombiano de Antropología e Historia/Instituto de Estudios Sociales y Culturales. Pensar/UIA de México, 2002.

BRUM, C. K. Integração: uma categoria para estudar a atuação do padre Antônio Sepp nas missões. In: QUEVEDO, J. Historiadores do novo século. São Paulo: Ed. Companhia Nacional, 2001, p.41-62.

CASTELNAU-L'ESTOILE, C. de. Operários de uma vinha estéril: os jesuítas e a conversão dos índios no Brasil 1580-1620. Bauru (SP): Edusc, 2006.

CERTEAU, M. A escrita da história. Rio de Janeiro: Forense Universitária, 2000.

CHAMORRO, G. Antonio Ruiz de Montoya: promotor y defensor de lenguas y pueblos indígenas. História Unisinos, v.11, n.2, p.252-260, maio-ago. 2007.

Sentidos da conversão de indígenas nas terras baixas sul-americanas. Uma aproximação linguística. In: SUESS, P. et al. Conversão dos cativos: povos indígenas e missão jesuítica. São Bernardo do Campo: Nhanduti Editora, 2009.

CHARTIER, R. História cultural: entre práticas e representações. Rio de Janeiro: Bertrad, 1990.

CONSTITVTIONES Societatis Iesv et examen cvm declarationibvs. Antverpiae: apud Joannem Meursium, 1635.

CORTESÃO, J. Manuscritos da Coleção de Angelis I: jesuítas e bandeirantes no Guairá (1549-1640). Rio de Janeiro: Biblioteca Nacional, 1951.

Manuscritos da Coleção de Angelis II: jesuítas e bandeirantes no Itatim (1596-1760). Rio de Janeiro: Biblioteca Nacional, 1952.

Manuscritos da Coleção de Angelis III: jesuítas e bandeirantes no Tape (1615-1641). Rio de Janeiro: Biblioteca Nacional, 1969.

DE ANGELIS, B. (org.). Epistolce proepositorum generalium ad patres et fratres Societatis Jesu. Antverpiæ, 1635.

DICCIONARIO de la lengua castellana, en que se explica el verdadero sentido de las voces, su naturaleza e calidad, con las phrases ò modo de hablar, los proverbios ò refranes y otras cosas convenientes al uso de la lengua. (Tomo Quarto). Madrid: En la Imprenta de la Real Académia Efpañola/Por los Herederos de Francisco del Hierro, 1734.

DICCIONARIO de la Lengua Castellana compuesto por La Real Academia Española, 1780.

DURKHEIM, É. As regras do método sociológico. 2.ed. São Paulo: Martins Fontes, 1999.

ELLIOT, J. H. A Espanha e a América nos séculos XVI e XVII. In: BETHEL, L. (org.). História da América Latina: a História da América Latina colonial. 
v.1. São Paulo; Brasília: Edusp; Fundação Alexandre Gusmão, 1998, p.283-337.

FLECK, E. C. D.; BOHN MARTINS, M. C., RODRIGUES, L. F. M. Itinerário cultural da região das Missões Jesuítico-Guaranis (síntese histórica). São Leopoldo, 2010.

FLORES, M. Reduções jesuíticas dos guaranis. Porto Alegre: EDIPUCRS, 1997.

FURLONG, G. Misiones y sus pueblos guaraníes. Buenos Aires: Imprenta Balmes, 1962.

GADELHA, R. M. d'A. F. Montoya e as relações de produção nas missões. Anais do VI Simpósio Nacional de Estudos Missioneiros - Montoya e as reduções num tempo de fronteiras. Santa Rosa: Fac. Filos. Ciências e Letras Dom Bosco, 1985, p.119-131.

GÁLVEZ, L. Guaranies y jesuítas: de la Tierra sin Mal al Paraíso. Buenos Aires: Editorial Sudamericana, 1995.

GASBARRO, N. Missões: a civilização cristã em ação. In: MONTERO, P. Deus na aldeia: missionários, índios e mediação cultural. São Paulo: Globo, 2006, p.67-110.

GUARATO, R. Por uma compreensão do conceito de representação. História e-história. Disponível em: <http://www.historiaehistoria.com.br/materia. $\mathrm{cfm}$ ? tb=artigos\&id= 17 edn1>. Acesso em: 16/11/2013.

HALBWACHS, M. La memoria colectiva. Revista de cultura psicológica, 1992, v.1, n.1, p.5-13.

HANSEN, J. A. Ler e ver: pressupostos da representação colonial. Disponível em: <http://www.geocites.com>. Acesso em: 16/11/2013.

HARTOG, F. O espelho de Heródoto: ensaio sobre a representação do outro. Belo Horizonte: Editora UFMG, 1999.

HOBSBAWM, E.; RANGER, T. (Eds.). La invención de la tradición. Barcelona: Crítica, 2002.

JAEGER, L. G. La Compañía de Jesús en el antiguo Guairá (1585-1631). Localización de sus trece reducciones. Pesquisas - Anuário do Instituto Anchietano de Pesquisas, v.1, p.93-180, 1957.

JARQUE, F. Ruiz de Montoya en Indias (1608-1652). Madrid: editado por Victoriano Suárez, 1900 [1662]. 4v.

KERN, A. A. Missões: uma utopia política. Porto Alegre: Mercado Aberto, 1982.

KLAIBER, J. Los jesuitas en América Latina, 1549-2000: 450 años de inculturación, defensa de los derechos humanos y testimonio profético. Lima: Fondo Editorial de la Universidad Antonio Ruiz de Montoya, 2007. 
LE GOFF, J. El orden de la memoria. El tiempo como imaginario. Barcelona: Paidós, 1991.

LÉON-DUFOUR, X. Resurrection and the Message of Easter. London: G. Chapman, 1974.

LÓPEZ AUSTIN, A. La construcción de la memoria. La memoria y el olvido, Segundo Simposio de Historia de las Mentalidades, 1985, p.75-79.

LOYOLAE, I. Exercitia Spiritvalia. Antvepiae, 1635.

MAEDER, E. J. A.; GUTIÉRREZ, R. Atlas territorial y urbano de las misiones jesuíticas de guaranies. Argentina, Paraguay y Brasil. Sevilla: Consejería de Cultura, 2009.

MELIÀ, B. Un catecismo bilingüe en guaraní y castellano. In: RUIZ DE MONTOYA, A. Catecismo de la lengua guarani (1640). Asunción: Centro de Estudios Paraguayos "Antonio Guasch" (Cepag)/ Fondec, 2008, p.5-35.

MELIÀ LITTERES, B. Génesis del Guaraní jesuítico del Guairá. Anais do Seminário Internacional Indígenas, Missionários e Espanhóis: O Paraná no contexto da Bacia do Prata: séculos XVI e XVII. Curitiba: Secretaria do Estado da Cultura, 2010, p.47-77.

MONTEIRO, L. N. Para narrar o céu e converter almas: padre Antônio Ruiz de Montoya e o estudo da língua guarani - séculos XVI-XVII. Anais do XXVI Simpósio Nacional de História - Anpuh. São Paulo: Anpuh, 2011, p.1-17.

NAZÉ, A. Inácio, Francisco e outros santos jesuítas. São Paulo: Edições Loyola, 2008.

RABUSKE, A. Antônio Ruiz de Montoya: vida e obra em geral. Anais do VI Simpósio Nacional de Estudos Missioneiros - Montoya e as reduções num tempo de fronteiras. Santa Rosa: Fac. Filos. Ciências e Letras Dom Bosco, 1985, p.43-56.

Subsídios para a leitura da "Conquista espiritual" de Montoya. Anais do VI Simpósio Nacional de Estudos Missioneiros - Montoya e as reduções num tempo de fronteiras. Santa Rosa: Fac. Filos. Ciências e Letras Dom Bosco, 1985, p.73-83.

REBES, M. I. A. de. Antônio Ruiz de Montoya: testemunha de seu tempo. 400f. Dissertação (Mestrado em História) - Programa de Pós-Graduação em História. Universidade do Vale do Rio dos Sinos, São Leopoldo, 2001.

ROCHA POMBO, J. F. História do Brasil. 9.ed. revista e atualizada por Hélio Vianna. São Paulo: Edições Melhoramentos, 1960.

RODRIGUES, L. F. M. "A mis em Xpo. Muy amados padres y hermanos dela Compañía de Jesu”. A escrita jesuítica segundo Inácio de Loyola. Revista Clio - Revista de Pesquisa Histórica, v.28, n.2, p.1-20, 2010. 
ROUILLON ARROSPIDE, J. L. Antonio Ruiz de Montoya y las Reducciones del Paraguay. Asunción: Centro de Estudios Paraguayos "Antonio Guasch", 1997.

Vida de Antonio Ruiz de Montoya. Lima: Escuela Superior de Pedagogía, Filosofia y Letras Antonio R. de Montoya, 2001.

RUIZ DE MONTOYA, A. Conqvista espiritval hecha por los religiosos de la Compañia de Iesus, en las Prouincias del Paraguay, Parana, Vruguay y Tape. Madrid: Imprenta del Reyno, 1639.

. Tesoro de la lengva gvaraní. Madrid: Iuan Sanchez, 1639.

Arte, y bocabvlario de la lengva gvaraní. Madrid: Iuan Sanchez, 1640.

. Catecismo de la lengva gvaraní. Madrid: Diego Díaz de la Carrera, 1640.

Sílex de el el Diuino amor y rapto activo de el aníma, em la memoría, entendímíento y voluntad quese emprende el Divuino fuego mediante vn acto de fé, que es el fundamento de esta obra [1648c]. Introducción, transcripción y notas de José Luis Rouillon Arróspide. Lima: Pontificia Universidad Católica del Perú/Fondo Editorial, 1991.

Apología en defensa de la doctrina cristiana que en la lengua guaraní tradujo el venerable padre fray Luís de Bolaños de la familia franciscana por el mismo Antonio Ruiz de Montoya (1651). Introdución y transcripción de Bartomeu Melià. Asunción: Fondec/Cepag, 2008, p.405-472.

SCHALLENBERGER, E. A integração do Prata no sistema colonial: colonialismo interno e missões jesuíticas do Guairá. Toledo: Editora Toledo, 1997.

SCHMITZ, P. I. Migrantes da Amazônia: a tradição tupi-guarani. In: KERN, A. A. et al. Arqueologia pré-histórica do Rio Grande do Sul. Porto Alegre: Mercado Aberto, 1991, p.295-330.

TESCHAUER, C. História do Rio Grande do Sul dos dois primeiros séculos. São Leopoldo: Editora Unisinos, 2002.

TORMOSANZ, L.; ROMÁN BLANCO, R. Montoya y su lucha por la libertad de los índios: Batalla de Mbororé. São Paulo: Eveloart, 1989.

VIANNA, H. Manuscritos da Coleção de Angelis IV: jesuítas e bandeirantes no Uruguai (1611-1758). Rio de Janeiro: Biblioteca Nacional, 1970. 


\section{INDÍGENAS AMERICANOS NA OBRA DE Jacoues Arago (1817-1854)}

Daniel Dutra Coelho Braga*

A trajetória ${ }^{1}$ de Jacques Étienne Victor Arago (1790-1854) é certamente instigante. Irmão de François Arago, renomado astrônomo francês, o viajante e desenhista atuou nos campos científico, artístico e literário da França. Embora tenha iniciado seus estudos em Direito, logo cedo manifestou o desejo por uma "vida agitada", para usar o termo do historiador François Sarda, o que o afastou do campo jurídico. Graças à intercessão do irmão François, membro da Academia Real de Ciências, Jacques Arago acompanhou o oficial da marinha Louis de Freycinet (1779-1842) em uma expedição de volta ao mundo iniciada em 1817. Arago foi encarregado de registrar, mediante desenhos, as paisagens, elementos naturais e povos encontrados ao longo da viagem, que durou três anos. Posteriormente, o desenhista morou em diversas cidades francesas, tendo residido em Bordeaux entre

* Mestrando do Programa de Pós-Graduação em História Social da UFRJ e integrante do Laboratório de História e Ecologia do Instituto de História da UFRJ.

1 Recorre-se ao conceito de trajetória tal como compreendido por Bourdieu (1994, p.78). O conceito de trajetória se diferencia da ideia de biografia, pois pressupõe uma série diferenciada de posicionamentos sociais sucessivamente ocupados. Nesse sentido, não haveria um nexo preestabelecido e necessário que unisse tais posicionamentos. Buscar tal nexo seria incorrer, de acordo com Bourdieu, em uma "ilusão biográfica” (ibid., p.81-89). 
1823 e 1828 e, depois, em Toulouse, Lyon e Rouen. Ao longo de sua vida na França, escreveu diversas peças, fundou o jornal de curta duração Le Kaléidoscope [O caleidoscópio] e participou de sociedades artísticas e literárias. Além disso, sua participação na vida política foi constante, tal como denotam muitas de suas publicações, além de sua participação nos combates de rua de 1848. Insatisfeito com o golpe de Estado promovido por Luís Napoleão Bonaparte, Arago se transfere para o Brasil, onde falece em 1854 (Lequeux, 2008, p.31-32; Sarda, 2003, p.185-201).

O objetivo do presente artigo é analisar algumas das representações referentes a indígenas americanos produzidas por Arago ao longo de tão complexa trajetória. Nesse sentido, destaca-se a série de cartas escritas ao longo da viagem de volta ao mundo junto a Freycinet, posteriormente editadas em 1839 no romance Souvenirs d'un aveugle [Lembranças de um cego]. Além disso, analisa-se o romance Les Deux Óceans [Os dois oceanos], publicado em 1854. Dentre os locais americanos descritos por Arago em tais textos, destacam-se a capitania do Rio de Janeiro e as ilhas Sandwich, na costa oeste americana, as quais integram o arquipélago posteriormente conhecido como Havaí. ${ }^{2}$ Para uma melhor compreensão das construções

2 O itinerário da expedição de Louis de Freycinet foi bem vasto. Os relatórios de Freycinet (1825, p.xiv-xx) registram o itinerário da viagem. Após deixar Toulon, os viajantes chegaram em Gibraltar no dia 11 de outubro, dirigindo-se posteriormente a Tenerife, onde se estabeleceram por dois dias. O Rio de Janeiro é o alvo seguinte da expedição, que se estabelece na então capitania por quase dois meses a partir de 6 de dezembro. Do Brasil a expedição parte para o Cabo da Boa Esperança, entre 7 de março e 5 de abril de 1818. Após cruzar o Cabo, a expedição se dedica ao estudo das ilhas do Oceano Índico. A Ilha de França, atual Ilha Maurícia, é o ponto seguinte do itinerário, onde os tripulantes se estabelecem entre 5 de maio e 16 de julho. Além disso, constaram no trajeto a Ilha de Bourbon, bem como a baía dos Chiens-Marins, posteriormente denominada pelos ingleses de Baía Shark, na Austrália, onde a tripulação permanece entre 12 e 26 de setembro de 1817. Em seguida, a expedição se dirige à Ilha do Timor, estabelecendo-se tanto em Coupang, região de domínio holandês, entre 9 e 23 de outubro, como também em Dicly, território português, onde permanecem até 22 de novembro. Seguem então para a Ilha de Rawak, próxima de Waigiou, atual Nova Guiné, no sudoeste do Oceano Pacífico. A expedição se estabelece 
textuais referentes às comunidades tradicionais americanas, realiza-se também uma reflexão sobre a literatura de viagem oitocentista, bem como sobre as tradições textuais de representação dos selvagens. Além disso, são analisados alguns textos contemporâneos aos de Jacques Arago, tais como os escritos pelo comandante Louis de Freycinet, pelo também viajante oitocentista Ferdinand Denis e pelo naturalista setecentista Bernardin de Saint-Pierre. Mediante comparações, busca-se identificar as especificidades dos textos do próprio Arago.

A literatura de viagens na qual esses relatos se inserem forma um corpus documental certamente complexo. Logo, ao analisá-los, é necessário identificar as filiações textuais que os compõem. Muitas vezes os relatos de viagem do século XIX sequer estavam comprometidos com alguma verdade referente à experiência da viagem. Em muitos aspectos, os relatos poderiam funcionar como uma oportunidade para os viajantes criticarem a sua própria realidade social, reificando elementos da vida de outros povos, considerados virtuosos e positivos. Os relatos de viagens imaginárias e utópicas se constituíram, portanto, em um gênero específico. Um exemplo emblemático de tal tradição é a obra de Jacques Cambry, Fragments du dernier voyage de La Pérouse [Fragmentos da última viagem de La Pérouse]. Nesse relato, Cambry descreveu a possibilidade do viajante

na ilha entre 16 de dezembro e 5 de janeiro de 1819. Ainda no Oceano Pacífico, a expedição permanece por cerca de três meses nas Ilhas Marianas. De acordo com Arago, eram vários os motivos que levaram a tripulação a permanecer tanto tempo nas ilhas, os quais se relacionavam sobretudo à manutenção das boas condições de viagem. Posteriormente, a expedição se dirigiu a Guham em 5 de abril e, em seguida, em 8 de agosto, a Owhyhée. As ilhas Mowi e Woahou também foram visitadas pela tripulação, que se dirigiu ao porto Jackson, na então Nova Holanda, em 30 de agosto. Uma vez no atual continente australiano, a expedição lá se estabelece até 25 de dezembro de 1819, dirigindo-se então para o arquipélago da Terra do Fogo, ao sul da América do Sul, estabelecendo-se na Baía do Bom Sucesso em 7 de fevereiro de 1820. Ao tentar cruzar o Cabo Horn, a expedição enfrenta um ciclone e altera seu rumo, dirigindo-se às Ilhas Malvinas. Após a passagem pela bacia do rio Prata, Freycinet retorna ao Rio de Janeiro, onde permanece por mais três meses, retornando à França em seguida, em novembro de 1820 . 
La Pérouse ${ }^{3}$ ter se deslocado para uma ilha paradisíaca, onde viveria longe do que concebia como as tristezas de uma França revolucionária submetida ao furor de Robespierre (Kury, 2001a, p.12-14). Os relatos, portanto, podem ter como referencial uma viagem que não aconteceu.

Ainda assim, a demanda pela literatura de viagens incluía a expectativa por informações verossímeis (Freitas, 1996, p.39). Daí a necessidade de, mesmo em obras de ficção, recorrer-se a dados científicos e formas de descrição também utilizadas nos gêneros propriamente científicos. O romance Souvenirs d'un aveugle, por exemplo, é publicado com notas científicas pelo irmão de Jacques, François Arago, o que denota uma preocupação não só com a satisfação da curiosidade do público mas também com a sua instrução e a persuasão mediante formulações científicas da época.

O primeiro texto mais abrangente de Jacques Arago é a coletânea de cartas escritas ao longo da viagem de volta ao mundo, entre 1817 e 1820, e publicadas inicialmente em 1822. A série foi um sucesso editorial no século XIX. Além de ter sido reeditada nove vezes, até mesmo décadas após a morte do viajante, a série foi traduzida para o inglês, alemão, italiano e espanhol (Sarda, 2003, p.187-188). No prefácio da publicação, Arago reitera a preocupação em publicá-las tal como foram escritas e enviadas a um suposto amigo de infância (Arago, 1823, p.vi). É possível conceber tal afirmação como um recurso estilístico no qual se reafirma a intenção de emular, através do recurso ao gênero epistolar, sentimentos de proximidade e intimidade para com o leitor, o que é um recurso usual na literatura de viagens (Roche, 2003, p.148-150). A escrita de cartas por parte de viajantes, no entanto, também poderia ter um sentido administrativo: elas seriam documentos regularmente enviados para o país natal dos viajantes ao longo da expedição, de forma a manter o controle por

3 O viajante Jean François de Galaup, o conde de La Pérouse, deixou a França em 1785 para realizar uma viagem de volta ao mundo. Entretanto, uma das embarcações da expedição naufragou. Para mais detalhes sobre a viagem de La Pérouse, ver Kury (2001a) e Taillemite (1999). 
parte do Estado sobre as atividades realizadas pela expedição (Freitas, 1996, p.74-77). Relatos e diários de viagem, enfim, poderiam ser uma forma através da qual os viajantes prestariam contas para com a sociedade que deixaram em sua terra natal.

A ideia de civilização orienta a maioria das representações de indígenas presentes na série de cartas de Arago. Os comentários do viajante acerca da conjuntura política então enfrentada pelo arquipélago do Havaí são um bom exemplo do uso da categoria. Em suas cartas, Arago discorreu longamente sobre as ações políticas inglesas no arquipélago, ${ }^{4}$ as quais corroboraram a ascensão do líder Kamehameha I, em detrimento de outros poderes locais. ${ }^{5}$ Quando se atém à

4 Segundo Taillemite, o arquipélago do Havaí suscitava ambições na Inglaterra, nos Estados Unidos e na Rússia. O historiador da Marinha francesa reitera a influência norte-americana na região, diferentemente de Jacques Arago, que reitera a influência inglesa. De acordo com Taillemite, os norte-americanos o frequentariam em função da caça às baleias e exploração madeireira. Para os russos, o arquipélago seria uma base bem situada para o tráfico de peles de animais entre o Alasca e a China, a ponto de o tsar ambicionar, após 1815, um estabelecimento permanente, recuando, porém, perante a hostilidade norte-americana. A Uranie chegou ao arquipélago no período da morte de Kamehameha I, em 8 de maio de 1819. Seu filho não teve as mesmas qualidades políticas e autoridade, de forma que a influência norte-americana cresceu ainda mais, embora o arquipélago tivesse sido teoricamente cedido à Inglaterra em setembro de 1794, quando da passagem de George Vancouver, o qual teria assinado um tratado com Kamehameha e outros chefes locais. Freycinet, por sua vez, desejava desenvolver a influência francesa no Havaí, projeto também visado por outros navegantes franceses que lá estiveram, sem êxito (Taillemite, 1999, p.489-490).

5 A crítica à Kamehameha I se dá em um viés duplo. Ao mesmo tempo em que Arago crítica a ilha Owhyhee por ser um país onde não haveria basicamente nenhuma lei, a ponto de afirmar que em meio a um povo indisciplinado e selvagem, seria fácil a ascensão de um poder como o deste rei (Arago, 1823, p.104), o viajante francês não deixa de comentar a intervenção política inglesa no arquipélago. O poder de Kamehameha I só foi efetivado mediante a proteção britânica. Os ingleses teriam, segundo Arago, mediado as dissensões políticas do arquipélago, corroborando tal sistema político equivocado. Arago ainda aproveita a análise da situação política para criticar as mudanças culturais nas ilhas dela decorrentes. Ao identificar a ausência de arquivos no arquipélago, afirma que tais nações, ao se valerem apenas da tradição, perdem suas características primitivas sem ao menos estarem cientes das mudanças (Arago, 1823, p.112). 
figura do líder, Arago emula uma determinada concepção de política, aliada ao ideal de civilização:

Tammeamah tinha sem dúvida um bom coração; sua disposição natural o levou a agir bem: porém, não obstante, todos os benefícios por ele conferidos, ainda podemos lamentar os infortúnios de uma nação que possui como modelo apenas os exemplos e lições de um só homem, sendo esse homem familiarizado apenas com os primeiros estágios da civilização e ainda não removido o suficiente do estágio selvagem de forma a permitir apenas a vigência de leis igualitárias e abolir costumes dos quais a mera ideia nos traz calafrios. ${ }^{6}$ (Arago, 1823, t.II, p.85) $)^{7}$

Apenas a menção à tópica da civilização não evidencia, contudo, os pressupostos aos quais Arago adere quando descreve os habitantes das ilhas Sandwich. Há detalhes específicos caros à ideia, os quais aparecem em outras seções do texto do viajante. A ideia de estágios de civilização emulada por Arago não pressupõe, por exemplo, qualquer forma de determinismo geográfico. $\mathrm{O}$ viajante, ao descrever em suas cartas as diferentes tribos que encontrou em todo o planeta, não utilizou a localização geográfica como um critério fundamental para compreender seus comportamentos. Ao descrever a Nova Zelândia, por exemplo, o viajante compara as tribos nela presentes àquelas que encontrou no Brasil, reificando a ferocidade das tribos de ambas as regiões:

6 As citações referentes à obra de Jacques Arago são traduções livres efetuadas pelo autor do presente trabalho.

7 Na tradução inglesa de 1823: "Tammeamah had undoubtedly a good heart; his natural disposition led him to act well: but notwithstanding all the benefits he conferred, we may still deplore the misfortunes of a nation which has only the examples and lessons of one mand as a model, and that man acquainted with the first stages of civilization; and not yet far enough removed from the savage state, to allow only equitable laws to remain in force, and to abolish customs of which the mere idea make us shudder". 
Ainda podem ser encontrados antropófagos cujos combates são deveras mortíferos; lá perambulam tribos que, tal como os paikices ou os mundrucus, cortam as cabeças de seus inimigos derrotados e as preparam de forma a preservá-las por anos. As mesmas armas, as mesmas maneiras ferozes, e quase que os mesmos traços no corpo e rosto são encontrados entre povos situados à distância uns dos outros; e, se eu acreditar nos relatos de viajantes, há também deuses com os mesmos nomes. Expliquem, se puderem, essa maravilhosa semelhança, conforme é particularmente encontrada em zonas tão diferentes: os primeiros habitam as regiões hiperboreais; os últimos, ao contrário, recebem os raios de sol perpendicularmente sobre suas cabeças. (Arago, t.II, 1823, p.232)

Tendo em vista essas descrições de Arago, torna-se possível perguntar: quais seriam, então, suas especificidades, sobretudo quando comparadas a uma longa tradição francesa de representação das Américas e dos ditos selvagens? A qual ideia de civilização Arago faz menção em seus textos? Finalmente, seria possível identificar continuidades e descontinuidades em sua obra, no tocante à representação dos indígenas?

Uma longa tradição de representação literária dos indígenas americanos é averiguável na França desde o século XVI, notadamente produzida por missionários e viajantes. Ao longo dos séculos XVI e XVII, para além de um "caráter de testemunho objetivo de uma suposta realidade", tais representações foram criadas mediante "preceptivas retóricas" que produziram objetos letrados primordialmente

8 Na tradução inglesa de 1823: "There are still to be found those Anthropophagi whose combats are so murderous; there yet wander savage tribes, who, like the Paikice, or the Mundrucus, cut off the heads of their vanquished enemies, and prepare them in such a way as to preserve them for years. The same weapons, the same ferocious manners, and almost the same designs on the body and face, are to be found among people situated so far from one another; and if I may believe the reports of voyagers, deities with the same names. Explain, if you can, this wonderful resemblance, particularly as it is found in such different zones: the former inhabit hyperborean regions; the latter, on the contrary, receive the sun's rays perpendicularly on their heads". 
governados por preceitos teológico-políticos (Daher, 2012, p.28). Em tal âmbito, os diferentes grupos indígenas americanos foram envolvidos pela ampla e genérica denominação de "sauvages". Apenas ao longo do século XVIII emerge um regime de representação diferenciado, sob o qual viajantes e escritores identificaram as especificidades das ditas tribos ou nações indígenas (Chinard, 1970, p.2). Portanto, classificar povos seria, à época da viagem de Arago e Freycinet, uma possibilidade relativamente recente na cultura europeia. As formas de classificação de seres humanos se apresentariam de maneira diferenciada principalmente a partir de meados do século XVIII, configurando a emergência do homem enquanto objeto científico (Foucault, 1966). O homem pôde tornar-se objeto científico mediante uma nova concepção de classificação dos seres vivos como um todo, na qual estes não seriam catalogados como singularidades divinas, mas sim sempre mediante as relações que apresentassem entre si, com base em suas próprias características, possibilitando a representação de um quadro de seres no qual um objeto não poderia ser compreendido e representado sem estar relacionado a outro. Essas formulações foram, por sua vez, continuamente discutidas no campo da disciplina História Natural (Foucault, 1966; Thomas, 1996).

Houve diferentes tradições de classificação de povos ditos "selvagens" à época das Luzes, nem todas diretamente tributárias da História Natural. De uma maneira geral, houve a circulação da tradição tributária da ideia do "bom selvagem", tal como formulada por Jean-Jacques Rousseau, a qual concebia povos tradicionais como exemplos do estado de natureza no qual predominaria um sentimento de pureza e virtude. ${ }^{9}$ Por outro lado, havia também concepções que consideravam muitos "selvagens" de maneira negativa. Nesse viés, destacam-se obras de filósofos como Buffon e Voltaire (Potelet, 1993, p.224).

9 Não se trata de afirmar que a ideia do bom selvagem tenha sido inventada por Rousseau. Tal como demonstra Gilbert Chinard (1970, p.341-365), seus textos podem ser situados dentro de uma linha de continuidade em relação a textos de séculos anteriores, elaborados sobretudo por missionários jesuítas. 
A classificação elaborada por Buffon apresentava especificidades, as quais culminavam em uma concepção específica da ideia de civilização. Se Voltaire tecia uma ideia de raça ainda tributária da concepção de singularidade divina, cara às tradições textuais dos séculos XVI eXVII, Buffon, por outro lado, concebia a ideia de raça como produto de uma história (Duchet, 1995, p.294). Nessa concepção, o parâmetro para classificar os povos seriam as formas pelas quais lidariam com a natureza. Os povos degenerado ${ }^{10}$ seriam aqueles que, embora afetados pela interação com o clima, não usufruiriam efetivamente do poder empreendedor conferido ao homem, capaz de reger e organizar a natureza. Sem o desenvolvimento de tal faculdade, os povos degenerados terminariam por "destruir sem edificar", comprometendo sua relação com a natureza. A civilização seria então o resultado de um bom domínio da natureza. Assim, Buffon estabelece uma relação entre forças morais e forças naturais no sentido de compreender o movimento, ao longo do tempo, dos diferentes povos, bem como suas possibilidades de classificação (Duchet, 1995, p.247). Logo, a ideia de civilização é cunhada no campo da disciplina História Natural não em oposição à ideia de natureza, mas sim enquanto melhor domínio possível desta (Kury, 2001a, p.22).

O estabelecimento de uma relação entre estágios de natureza e modos de subsistência não foi feito apenas pelo naturalista Buffon. De acordo com o historiador Ronald Meek, tal associação foi, na verdade, uma tendência importante no campo filosófico do século das

10 Cabe ressaltar o significado da ideia de degeneração no contexto mais amplo da obra do naturalista. Buffon utiliza o termo no intuito de identificar todo e qualquer elemento que teria sofrido alterações em função de efeitos acumulados da alimentação, do clima e do modo de vida, de forma a modificar os perfis de uma linhagem de organismos (Caponi, 2010, p.144). O uso do termo, portanto, não pressupõe a identificação de uma qualidade negativa em si, ou seja, não se trata de atribuir um juízo de valor à transformação, mas sim de identificá-la, apenas. Convém apontar que parte da originalidade do trabalho de Buffon, no século XVIII, se deu justamente por sua formulação acerca do transformismo no quadro de classificações da espécie - sem necessariamente formular uma teoria da evolução tal como feito por Darwin no século seguinte. Para detalhes, ver Caponi (2010). 
Luzes como um todo, tendo sido emulada não só pelos naturalistas franceses, mas também por pensadores como Adam Smith. Esses pensadores do final do século XVIII, ao articularem a ideia de estágios de sucessos no desenvolvimento dos povos à análise dos diferentes modos de subsistência, estariam dando uma nova dimensão à frase registrada por John Locke no final do século XVII: "Nos primórdios, todo o mundo era América" (Meek, 2010).

As grandes viagens científicas de fins do século XVIII e primeiras décadas do século XIX interagiram diretamente com tais concepções acerca dos povos ditos selvagens. Era com base na literatura de viagens que muitos philosophes como Voltaire e Buffon puderam analisar e comparar os diferentes povos e costumes (Duchet, 1995). As viagens contribuíram para um gradual declínio da ideia do "bom selvagem" tal como exaltado por Rousseau, na medida em que permitiram o registro de práticas tidas como cruéis e injustas (Bourguet, 1997). Ainda assim, cada viagem modelou, à sua maneira, as novas possibilidades de representar selvagens. $\mathrm{O}$ viajante Bougainville, no século XVIII, ainda exaltava a possibilidade de encontrar o homem natural e o paraíso de uma "era de ouro" primordial. Já os viajantes posteriores, tais como Lapérouse e d'Entrecasteaux, se esforçaram por representações de caráter mais científico, de acordo com as novas formulações em circulação no campo da História Natural. A viagem de volta ao mundo de Freycinet se filiou a tal esforço, no intuito de elaborar representações rigorosas acerca dos povos encontrados (Taillemite, 1999, p.484).

Diversos trabalhos historiográficos apontam, no entanto, para a coexistência de visões de mundo diferentes no interior da própria expedição de Freycinet (Benoit-Guyod, 1942; Taillemite, 1999). Tal diferença propiciou a criação de representações diversas acerca das comunidades tradicionais encontradas. Segundo Étienne Taillemite, historiador da Marinha francesa, nenhum dos integrantes da tripulação pôs em dúvida os feitos da civilização europeia: o comandante Freycinet, embora fosse um verdadeiro herdeiro dos ideais de progresso e razão do século das Luzes, demonstrava forte adesão ao catolicismo, evidenciando que, a seu ver, a civilização e a religião 
caminhariam juntas; o médico e naturalista Jean-René Quoy, por sua vez, seria um humanista cético, mas que não colocava em dúvida a superioridade da civilização europeia. Em tal quadro, Jacques Arago seria a figura mais complexa. Com algumas nuances, o desenhista se mostraria como um verdadeiro "moraliste voltairien", sempre exaltando os valores da justiça e da razão, os quais ele identificaria até mesmo em muitos dos povos selvagens. Nesse sentido, Jacques Arago pode ser considerado um idealista, pacifista e talvez até um anticolonialista, na medida em que lamentou o fato de que, pelo contato com viajantes europeus, muitas civilizações autóctones poderiam ser destruídas (Taillemite, 1999, p.488).

De fato, apesar de toda uma tradição textual na qual as comunidades tradicionais americanas foram descritas como menos complexas, os textos de Arago apresentam passagens que as exaltam, como se vê nas cartas publicadas após sua primeira viagem. Em sua passagem pela Ilha de Owhyhee, o viajante celebrou a capacidade artesanal dos nativos, ao descrever suas casas:

Elas são produzidas através de um instrumento chamado, na região, de toë, o qual pode ser comparado à enxada de um carpinteiro, embora muito menor, e moldado para ser utilizado em uma só mão. Nossos marceneiros não lustram melhor a mais cara mobília; e sem plantas ou qualquer uma das ferramentas utilizadas por nossos trabalhadores, aqueles de Owhyhee são capazes de competir com os melhores artesãos da Europa. (Arago, t.II., 1823, p.65-66) ${ }^{11}$

Uma percepção menos rígida do desenvolvimento de outros povos denota os vínculos de Jacques Arago com outra tradição textual: a cultura romântica. De fato, outra forma de conceber a história e costumes de outros povos emergiu com a tradição romântica. A

11 Na tradução inglesa: "They are made by means of an instrument called in this country toë, which may be compared to a carpenter's adze, though much smaller, and fit to be used by one hand. Our cabinet-makers do not polish the most costly furniture better; and without planes or any of the tools employed by our workmen, those of Owhyhee are capable of competing with the best artisans of Europe". 
literatura de viagem de fins do século XVIII e início do XIX se entrelaça à emergência de tal tradição, pois trouxe à cultura europeia novos elementos para a representação de populações tradicionais. Assim, a cultura europeia é transformada mediante uma relativização de muitos alicerces da cultura iluminista, uma vez que "o cosmopolitismo universalista dos cidadãos do mundo dá lugar a um internacionalismo de especificidades geográficas e históricas que encontra sua expressão nos relatos de viagem" (Gusdorf, 1982, p.298). ${ }^{12}$

A adesão de Jacques Arago à cultura romântica se evidencia na edição de sua série de cartas em 1839: Souvenirs d'un aveugle apresenta elementos novos quando comparado à série original, o que permite seu vínculo à tradição romântica. $O$ romance é, basicamente, uma reformulação da série de cartas antes publicadas, com a transformação, porém, da linguagem utilizada e a inserção de novos diálogos e descrições de cenas entre personagens. A pauta iluminista do ideal de civilização se mantém, mas há também a ativação de recursos da tradição textual romântica. Segundo Potelet, a escolha de palavras que evidenciam a subjetividade do autor, a tentativa de expressar a complexidade de suas impressões das experiências com os locais e povos encontrados e a menção à ideia de lembranças no próprio título da obra denotam a adesão a um léxico caracteristicamente romântico. ${ }^{13}$ Soma-se ao léxico romântico da nostalgia e da subjetividade a menção não só no título como também ao longo do romance à doença do autor, a qual comprometeu sua visão. A obra adquire, assim, um teor autobiográfico e se destaca, além disso, no que diz respeito às representações do Brasil, por reafirmar uma tradição textual de compaixão pelos negros, a qual foi emulada por outros viajantes e românticos que passaram pelas Américas e terminaram por constituir uma verdadeira tradição de representações

12 Tradução do original francês realizada pelo autor do presente trabalho.

13 Para uma análise das formulações científicas realizadas por viajantes com base na filosofia romântica, decorrentes da constatação da complexidade dos fenômenos naturais perante a cognição humana, ver Kury (2001b). 
românticas do negro escravo, em que o cativo é descrito de maneira heroica (Potelet, 1993, p.212-219).

Entretanto, a adesão de Jacques Arago ao programa romântico é, no tocante à representação indígena, ambígua. Descritos mediante o uso da categoria sauvages, os nativos brasileiros, por exemplo, são por vezes elogiados e por vezes criticados. Um exemplo de virtude dos nativos como um todo seria seu apreço aos antepassados e o culto às lembranças. Nesse quesito, os "selvagens" são tidos como exemplo para os próprios europeus, os quais são vistos por Arago como desmemoriados e ingratos (Arago, 1868, p.48). Há aqui um claro exemplo de como os relatos de viagem sobre o "outro" poderiam funcionar como locus de crítica sobre a sociedade do próprio viajante. A reivindicação por um maior cuidado em relação à memória de antepassados, sobretudo no sentido de corroborar determinadas tradições, é, por sua vez, uma tópica romântica (Gusdorf, 1982, p.63).

Ao transformar suas cartas no romance Souvenirs d'un aveugle, Arago discorre mais pormenorizadamente sobre os indígenas brasileiros. Ao descrevê-los, o viajante se atém aos Tupinambá, Botocudo e Parikicé. Os Tupinambá seriam, segundo Arago, os mais ferozes, exprimindo sentimentos de amor tão verdadeiros, violentos e energicamente que seria possível denominá-los "heroicos", ainda que como resultado de tal intensidade se dessem, frequentemente, as mais horríveis vinganças (Arago, 1868, p.49):

O Brasil, como as outras porções deste continente, teve também suas perseguições, suas crueldades, seus massacres. Tribos inteiras foram sacrificadas, nações inteiras desapareceram; outras foram forçadas a se retirar ao cume de montanhas, a se esconder nas profundezas de florestas, a se recolher em situações onde estivessem separados de seus inimigos por imensos desertos, rios e torrentes. Aqui o perigo era real para os europeus. Homens ferozes habitavam essas regiões, suas canções eram urros e gritos de guerra; seus banquetes, cenas asquerosas de cadáveres devorados; suas tigelas eram os crânios ainda sangrentos dos inimigos derrotados. Dentre essas tribos tão terríveis, a dos Tupinambás se fazia distinguir por sua coragem e crueldade, e 
quando Pédralvez chegou ao Brasil, ele o encontrou sob a posse destes em quase toda a costa. $\mathrm{O}$ nome deste povo derivava da palavra Toupan, que significa trovão, o que parecia indicar sua força e poder. (Arago, 1868, p.46) $)^{14}$

Ao enfatizar o conflito entre as próprias "nações" indígenas, o escritor evidencia a especificidade e história de cada grupo indígena. Arago não incorre, portanto, na idealização de um índio brasileiro unívoco, tal como concebido por muitos românticos brasileiros. ${ }^{15} \mathrm{~A}$ atenção conferida aos termos indígenas, por sua vez, também situa Arago em uma tendência cara ao século XIX, na qual elementos da língua de povos tradicionais seriam literalmente coletados, quase que como amostras de elementos da natureza, ainda no sentido de possibilitar a criação de um quadro de compreensão da história dos diferentes povos.

14 A mesma passagem está registrada nas cartas publicadas anteriormente. Para detalhes, ver Arago (1823, p.96). No original francês: "Le Brésil, comme les autres parties de ce continent, a eu aussi ses persécutions, ses cruautés, ses massacres. Des peuplades entiéres ont été immolées, des nations ont disparu; d'autres ont étéforcées de se retirer au sommet des montagnes, de se cacher dans le fond des forêts, et de mettre entre elles et leurs ennemis des déserts immenses, des fleuves et des torrents. Ici le danger était réel pour les Européens. Des hommes féroces peuplaient ces contrées; leurs chansons étaient des burlements et des cris de guerre; leurs festins, des scènes hideuses de cadavres dévorés; leurs coupes étaient les crânes encore sanglants de leurs ennemis vaincus. Parmi ces peuplades si terribles, celle des Tupinambas se faisait distinguer par son courage et sa cruauté, et lorsque Pedralvez aborda au Brésil, il la trouva maîtresse de presque toute la côte. Le nom de ce peuple dérivait du mot Toupan, qui veut dire tonnerre, ce qui semblait indiquer sa force et sa puissance".

15 No romantismo brasileiro, o indígena foi escolhido como símbolo da nacionalidade. Como o Império buscava se contrapor à colonização, o índio foi eleito como símbolo da alteridade em relação à época colonial. No entanto, esse foi um índio idealizado. Os povos indígenas foram unificados a partir da construção do mito da identidade nacional, em detrimento do reconhecimento das especificidades de cada tribo. Essa idealização recebeu críticas, até mesmo dentro do movimento romântico. O escritor José de Alencar foi um dos que criticou essa idealização. Alencar teceu críticas ao livro de Gonçalves de Magalhães, A Confederação dos Tamoios, de 1856, dizendo que os indígenas presentes na obra "poderiam figurar em um romance árabe, chinês ou europeu” (Schwarcz, 1998, p.133-134). 
Os Botocudo ${ }^{16}$ também foram descritos por Jacques Arago, recebendo muito mais atenção no romance editado do que haviam recebido anteriormente, na série de cartas. A racionalidade específica das ações é identificada, na medida em que o viajante reconhece, nos jogos dos Botocudo, exercícios de destreza. Tendo isso em vista, Arago relata como esses homens "extraordinaires" traçariam circunferências no solo, posicionando-se em seguida em seu centro e atirando aos céus de forma que as flechas caíssem quase sempre dentro do círculo. Ao descrevê-los fisicamente, Arago afirma andarem completamente nus, com cabelos longos. Tal como os Tupinambá, eles fariam descer aos seus ombros as cartilagens de suas orelhas, além de fixar no lábio inferior, perfurando-o, um pedaço rígido de madeira que se estenderia até o queixo (Arago, 1868, p.47). Em um exercício textual de comparação entre povos, o viajante afirma:

O botocudo é, sem dúvida, o selvagem mais corajoso, mais inteligente, habilidoso do mundo. Nem os malaios com seu crish envenenado, nem o guebeano sobre seus caraccores, nem o zelandês com seu cassetete de pedra, nem o habitante das Ilhas Carolinas com seu bastão tão admiravelmente talhado, nem mesmo o habitante antropófago de Ombay, onde minha vida correu tantos perigos, podem se comparar ao botocudo munido de seu arco, de suas flechas e de seu pequeno saco de pedras. (Arago, 1868, p.47, grifos de Arago) $)^{17}$

16 Segundo Costa, os índios botocudos foram "os nativos mais temidos e difamados na literatura de viagem”. Os relatos de viagem do príncipe Maximiliano de Wied-Neuwied, no entanto, promovera uma nova forma de representação da tribo. A ideia de civilização, no entanto, manteve-se como eixo central das descrições, sendo os Botocudo exaltados justamente por serem, de acordo com o príncipe, passiveis de serem civilizados (Costa, 2008, p.5-6). Maximiliano também teria sido, segundo Costa, um dos autores a reiterar que a denominação "botocudo" é de origem europeia, sendo a tribo descendente dos Aimoré(Costa, 2008, p.25).

17 No original: "Le Botocudo est, sans contredit, le sauvage le plus brave, le plus intelligent, le plus adroit du monde. Ni le Malais avec son crish empoisonné, ni le Guébéen sur ses caraccores, ni le Zélandais avec son casse-tête en pierre, ni le Carolin avec son bâton si admirablement ciselé, ni même l'Ombayen anthropophage, chez 
Apesar de reconhecer a coragem e o apreço aos antepassados demonstrados pelos indígenas brasileiros, a escrita de Arago se torna ambígua no momento em que analisa as práticas de punição das tribos, bem como seus conflitos. Arago encerra a seção de seu texto narrando um conflito entre tupinambás e parikicés, deixando clara sua expectativa pelo fim da presença de tais "raças cruéis", as quais se destruiriam umas às outras e rapidamente desapareceriam da Terra, o que era esperado pelo viajante em função da felicidade da humanidade (Arago, 1868, p.50).

As Ilhas Sandwich também são objeto de descrições do romance e das cartas. Novamente, há descrições ambíguas em torno das populações tradicionais. A identificação da violência nas "nations" do arquipélago não é feita sob o mesmo teor referente aos indígenas brasileiros, cuja violência seria por vezes inata. No entanto, constata-se, ainda assim, uma capacidade assustadora de violência, sob condições específicas:

Ah bem! Estude o povo que vive ao redor dessas crateras dominadoras, e encontre neles um reflexo dessa ávida e selvagem natureza que vos faz tremer em vossa admiração. O sandwichien é ao mesmo tempo abrupto, pesado e turbulento; seu caráter é bom por instinto, e suas maneiras, assim como seu esqueleto, tem algo de rude e de repulsivo. Nele, todas as paixões fermentam em seu peito; é necessária uma catástrofe para que ele as lance para fora; mas então eles são terríveis: matam, esmagam, devoram. Cook foi morto em meio a uma dessas convulsões. (Arago, 1868, p.230) $)^{18}$

lequel ma vie a couru de si grands dangers, ne peuvent se comparer au Bouticoudo muni de son arc, de ses fléches et de son petit sac de pierres".

18 No original: "Eh bien! étudiez le peuple qui vit autour de ces cratères dominateurs, et vous retrouvez chez lui un reflet de cette apre et sauvage nature qui vous fait trembler dans votre admiration. Le Sandwichien est abrupt, lourd et turbulent à la fois; son caractére est bon par instinct, et ses manières, ainsi que sa charpente, ont quelque chose de rude et de repoussant. Toutes ses passions, à lui, fermentent dans sa poitrine: il faut une catastrophe pour qu'il les jette au dehors; mais alors aussi elles sont terribles, elles tuent, eles écrasent, elles dévorent. Cook est mort dans une de ces convulsions". 
Ao comentar os hábitos e a economia de trocas presente na ilha, Arago (1868, p.225) elogia os povos, afirmando que o egoísmo não faz parte da cultura dos sandwichiens. ${ }^{19}$ No entanto, o mesmo sistema de trocas, ao envolver as mulheres da ilha, traz repulsa ao viajante francês. Os sandwichiens tinham como costume oferecer suas mulheres aos visitantes que na ilha desembarcavam. Diante de tal prática, Arago registra sua reprovação, afirmando que as palavras "civilização" e "pudor" não possuiriam sentido para os nativos (Arago, 1868, p.222).

A relação entre os habitantes das Ilhas Sandwich e a agricultura é outro ponto criticado por Arago no romance, o que comprova sua adesão a uma concepção de civilização baseada nos modos de subsistência dos diferentes povos. O viajante exalta os coqueiros, as bananeiras, os tamarindeiros e as mamoneiras do local, mas lamenta a falta de cultivo por parte dos habitantes, afirmando que os nativos nada fazem para lutar contra a acusação de preguiça recorrentemente feita por viajantes. Tendo isso em vista, Arago compara os sandwichiens a outros povos, tentando explicar a falta de cultivo através dos hábitos alimentares dos nativos. Uma vez que os sandwichiens comem apenas ao sentir fome, a cultura se torna inútil, a ponto de os habitantes das Ilhas Marianas, também criticados por Arago em seção anterior do romance, assemelharem-se a glutões quando comparados aos habitantes das Ilhas Sandwich. Arago infere que um europeu provavelmente morreria de inanição caso tivesse de se contentar com a porção de comida usualmente digerida pelos nativos. Ao comentar os governos locais, Arago elogia as medidas do líder Kamehameha ("Tamahamah"), que teria feito concessões de terrenos para homens dispostos a cultivá-los, reservando-se o direito de puni-los caso não aproveitassem os terrenos concedidos. Entretanto, o viajante reprova as medidas do filho de Kamehameha, Riouriou, que teria deixado a população seguir seus próprios caprichos, deixando as terras inférteis. $\mathrm{O}$ viajante francês termina por concluir que a apatia dos sandwichiens em relação ao cultivo da terra seria também recorrente em

19 Optou-se por manter o termo original utilizado por Jacques Arago. 
todos os seus hábitos de vida, e não apenas no uso da terra (Arago, 1868, p.226).

A comparação entre hábitos alimentares de vários povos é mote de outro texto de Arago: a obra Jantares em diferentes países. Nela, Arago registra os hábitos alimentares de diversos povos para criticar as consequências morais dos hábitos dos próprios europeus, no intuito de demonstrar que, "na verdade, os povos civilizados são os mais selvagens do mundo" (Arago, 2006, p.16). Destaca-se a constante referência a textos bíblicos e à moral cristã, sobretudo em suas vertentes que primam pelo ideal de frugalidade. O teor moralista cristão de tal obra se coaduna às reflexões registradas em Souvenirs d'un aveugle, corroborando mais uma vez a possibilidade de compreender parte da obra de Arago em uma linhagem textual romântica francesa, tendo em vista que dois aspectos caros ao romantismo francês foram, segundo Stephen Bann, a exaltação da religião e a descoberta da alteridade na história (Bann, 1988, p.253).

Agora, porém, o alvo de Arago são seus próprios conterrâneos:

Os povos menos civilizados, mais rudes, em geral se preocupam menos em satisfazer o corpo com a boa mesa. [...] Mas nós, que somos mais esclarecidos e mais instruídos, deveríamos reconhecer que nos esmeramos em cuidados excessivos e vergonhosos, com essa ação bestial que consiste em mastigar a matéria com os dentes para introduzi-la no estômago. (Arago, 2006, p.105)

Contudo, muitos povos tradicionais tampouco são poupados por Arago na obra. Os próprios habitantes das Ilhas Sandwich são criticados pela forma cruel através da qual cozinhavam animais, atirando-os ainda vivos ao fogo (Arago, 2006, p.61-64).

O registro dos jantares elaborado por Arago não é apenas um inventário de quadros pitorescos, exóticos ou cruéis. É justamente em suas representações dos diferentes rituais alimentares por ele testemunhados que podemos compreender em que medida Arago se valeu da representação de outros povos para criticar a sua própria sociedade. Logo após Jantares em diferentes países, Arago publicou, 
na França, a obra Comme on dîne à Paris [Como jantar em Paris], na qual tece críticas severas à desigualdade social de seu país. ${ }^{20}$ Em sua denúncia da fome e da mendicância parisienses, os diversos jantares selvagens aparecem como um modelo positivo. A obra é uma resposta às diversas críticas que Arago teria recebido de leitores insatisfeitos ao encontrarem somente descrições de jantares em locais exóticos ou selvagens, posto que as grandes capitais europeias não eram mencionadas no livro. Em resposta, Arago se vale justamente do próprio ideal de civilização, agora para criticar não os selvagens, mas sim Paris, cidade onde, "como em todo país civilizado, aquele que carece totalmente de dinheiro carece totalmente dos meios de adquiri-lo. Nada é mais fácil que ganhar um milhão, nada é mais difícil que ganhar um tostão" (Arago, 1842, p.25). ${ }^{21}$ A antropofagia também é convertida em um recurso literário subordinado à crítica da desigualdade. No intuito de refutar a ideia de que não haveria antropófagos em Paris, Arago é enfático ao afirmar que em nenhuma outra região da Terra seria possível encontrar homens mais empenhados em devorar uns aos outros (Arago, 1842, p.34). Finalmente, em uma comparação

20 O uso literário das polêmicas acerca das desigualdades sociais não foi exclusivo de Jacques Arago. Como demonstra Jean-Pierre Bédeï (2012), ao longo da década de 1840, uma série de escritores se dedicou passionalmente à descrição dos problemas que afligiam não apenas a sociedade parisiense mas a francesa como um todo, o que culminou nas mais variadas produções literárias sobre questões políticas e sociais. A atividade não se restringiu à publicação de romances. Destaca-se, nesse sentido, o jornal Le Salut Public, cujas duas edições foram publicadas em 1848 por Charles Baudelaire, Jules Champfleury e Charles Toubin (Bédeï, 2012, p.87). É possível inferir, portanto, que, à época de Arago, a própria condição de escritor era um estímulo para que tais temas fossem abordados. Além disso, convém indicar a presença de Jacques Arago em um círculo amplo de sociabilidade do campo literário francês da época, o qual incluia nomes como Victor Hugo e Stendhal, os quais dedicaram suas penas a motivos políticos. No que tangue especificamente os manifestos políticos de 1848, Jacques Arago publicou "Aux juges des insurgés" (Sarda, 2003, p.192, 197).

21 No original: "Ici, comme dans tout pays civilisé, qui manque totalement d'argent manque totalement de moyens d'en acquérir. Rien n'est plus facile à gagner qu'un million, rien n'est plus difficile à gagner qu'un petit écu”. O termo "tostão" foi deliberadamente escolhido, no sentido de evidenciar o contraste visado pelo escritor. 
direta entre o que testemunhava na França e suas viagens pelo mundo, Arago lamenta, interpelando o leitor:

Percorra as duas Índias, os numerosos arquipélagos que enfeitam os oceanos, os vastos continentes descobertos há menos de um século, e em todos o homem selvagem encontra o que comer, o que beber. Água, frutas, alguns animais domésticos, legumes, um abrigo, nada daquilo lhe falta, ao passo que entre nós, nação dominante, tocha resplandecente que levará a luz das artes e das ciências às regiões mais longínquas, entre nós que temos a pretensão de regenerar a espécie humana (inumana, eu deveria dizer), o homem morre de fome, de frio, e nem sempre possui sequer um leito miserável sobre o qual repousar sua cabeça. (Arago, 1842, p.68-69) ${ }^{22}$

A tópica da prodigalidade da natureza que oferece ao homem aquilo que ele de fato necessita é apropriada por Arago, portanto, para criticar a sua própria sociedade. Uma mudança de registro de seus escritos, no tocante à representação dos selvagens, começa a se delinear, culminando em representações cada vez mais distantes da denúncia da crueldade inata tal como evidenciada nas cartas de 1823. O "selvagem" passa, cada vez mais, a ser habilitado como um dos eixos de um discurso comparativo sobre as injustiças francesas.

Tal mudança é o que se identifica no romance Les Deux Océans, obra na qual locais e costumes da América são, de uma maneira geral, exaltados. O romance é dedicado ao imperador d. Pedro II e denota as filiações políticas de Jacques Arago no final de sua vida, sobretudo tendo em vista sua decepção com o golpe de Estado executado

22 No original: "Parcourez les deux Indes, les nombreux archipels qui parent les océans, les vastes continents découverts depuis moins d'un siècle, partout l'homme sauvage trouve de quoi manger, de quoi boire. De l'eau, des fruits, quelques animaux domestiques, des légumes, un abri, rien de tout cela ne lui manque, et chez nous, nation dominatrice, flambeau éclatant qui va porter la lumière des arts e des sciences jusqu'aux régions les plus éloignées, chez nous qui avons la prétention de régénérer l'espèce humaine (c'est inhumaine que je veux dire), l'homme meurt de faim, de froid, et n'a pas toujours un grabat pour reposer sa tête". 
por Napoleão III. No prefácio do romance, o viajante afirma que há momentos nos quais democracia e realeza podem andar lado a lado, afirmando em seguida seu desejo em ser um súdito de d. Pedro II (Arago, t.I., 1854, p.5-6).

A descrição positiva referente ao Brasil pode ser interpretada como uma das estratégias de Jacques Arago para se posicionar no campo literário ${ }^{23}$ brasileiro. Segundo François Sarda, Jacques Arago esperava obter de d. Pedro II a direção do teatro Imperial de São Pedro, no qual foi apresentada sua peça L'Éclat de rire [A gargalhada] (Sarda, 2003, p.199). A apresentação da peça, sua interação com João Caetano dos Santos, bem como uma audiência marcada com o próprio d. Pedro II, são registradas no romance Les Deux Océans (Arago, t.III, 1854, p.207-211). Além disso, em seu último romance, Aragoé enfático ao elogiar a natureza brasileira. Descrevendo aquela que teria sido sua terceira passagem pelo que chama de "mon beau Brésil", o viajante francês exalta:

Eu reencontro aquilo que tanto amei, as brisas carinhosas, os cantos dos negros, o assobio singular de seus papagaios, e creio ouvir e ver voando ao meu redor as borboletas, matizadas, os beija-flores, ainda mais ricos e mais deslumbrantes, que o olho mal pode seguir suas loucas alterações. (Arago, t.III., 1854, p.196)

Os povos tradicionais americanos, contudo, continuam uma referência distante, mesmo no último romance de Arago. O viajante, em Les Deux Océans, opta por descrever o contato com grupos ditos civilizados e até mesmo os agentes em um primeiro momento rotulados como selvagens, tal como a jovem chilena Rosita (Arago, t.II, 1854, p.100), só recebem a atenção da pena de Arago quando são elogiados por sua integração com os hábitos civilizados. A denominação de "selvagem" é empregada, portanto, para ser posteriormente desconstruída. Ainda assim, no que diz respeito aos povos tradicionais

23 Faz-se referência ao conceito de campo literário tal como formulado por Bourdieu (1992). 
da América, o registro, ainda que evidencie de maneira nítida a diferença entre os estágios de civilização e aquele no qual os habitantes se encontram, já não é tão severo como os realizados logo após a expedição de Freycinet, quase trinta anos antes:

Há povos cuja conquista é impossível. Selvagens, como sua eterna solidão, constroem entre eles e a civilização uma barreira de areia, de rochas ou de florestas virgens cujo silêncio e profundeza somente eles ousam interrogar. Os sábios exploradores não possuem nem o tempo nem a coragem necessários ao aprimoramento das raças primitivas, que só têm por inimigos, até o presente, as bestas ferozes ou venenosas e a cólera dos elementos. Aqui, no entanto, reside a verdadeira glória do viajante que compreender a importância de sua missão; aqui apenas ele encontra o valor de seus trabalhos e de sua fadiga; aqui apenas ele encontraria a utilidade no presente e no futuro, para o pregador e o discípulo, para o homem da natureza e o homem de nossas cidades. (Arago, 1854, t.1, p.146) ${ }^{24}$

Ao afirmar que os selvagens possuem como inimigos apenas as bestas e os elementos naturais, Arago recusa a ideia de uma crueldade inata, cara a muitos textos de viajantes do século XIX. Além disso, há uma reflexão explícita sobre a própria identidade do viajante: ela não se basearia no dever de aprimorar raças, o qual seria compartilhado pelos ditos sábios, mas sim na missão de observar o valor de elementos opostos, unidos justamente através da experiência da viagem.

24 No original: "Il y a des peuples dont la conquête est impossible. Sauvages comme leurs éternelles solitudes, ils mettent entre eux et la civilisation une barrière de sables, de roches ou de forêts vierges dont eux seuls osent interroger le silence et la profondeur. Les savant explorateurs n'ont ni le temps, ni le courage nécessaires à l'amélioration des races primitives qui n'ont pour ennemis, jusqu'à présent, que les bêtes féroces ou venimeuses et la colère des éléments. Là, cependant, serait la vraie gloire du voyageur qui comprendrait l'importance de sa mission; là seulement il trouverait le prix de ses travaux et de ses fatigues; là seulement il y aurait utilité dans le présent et dans l'avenir pour le prédicateur et le disciple, pour l'homme de la nature et l'homme de nos cités". 
Para uma compreensão dos motivos artísticos baseados nos indígenas, uma análise da obra de Arago envolve também sua produção iconográfica. Dentre os textos supracitados, a série de cartas publicadas após a viagem de volta ao mundo contém gravuras elaboradas pelo próprio Jacques Arago. São obras comprometidas com a possibilidade de transmitir ao público europeu não só as características físicas dos povos encontrados, ou seja, características que permitem sua classificação dentro do quadro maior de espécies e povos do mundo, mas também atos e costumes que poderiam ou não atestar o grau de civilização desses povos. Um exemploéa preferência por representar, dentre os costumes dos habitantes das Ilhas Sandwich, um tribunal: uma forma cruel, agressiva e degenerada de implementar a justiça.

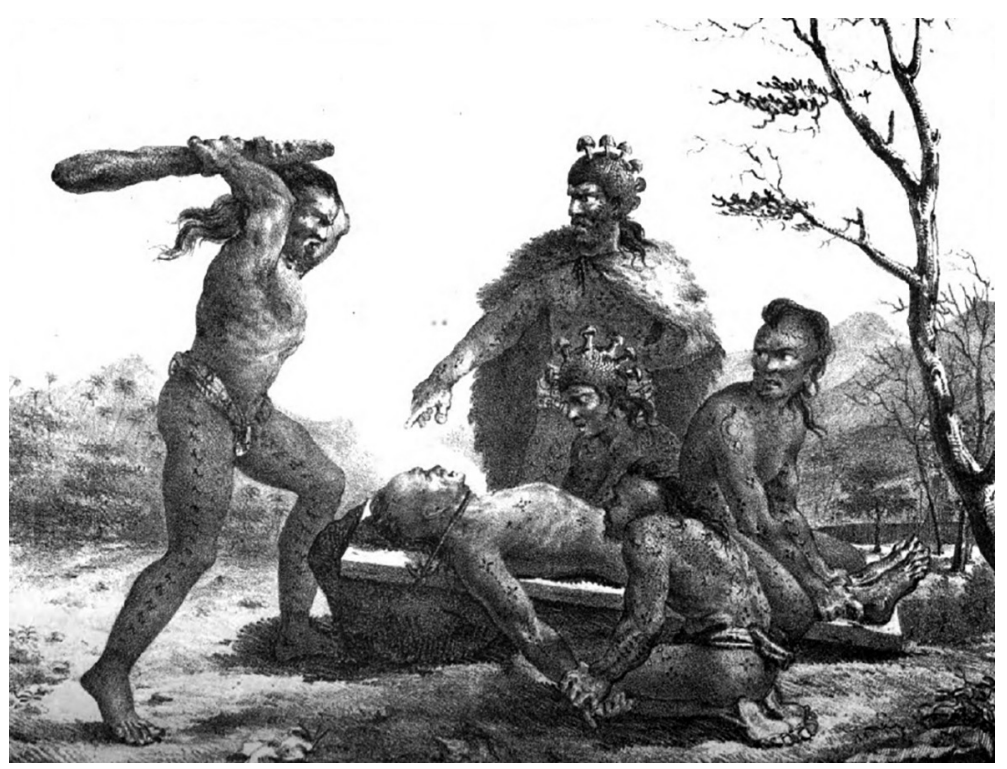

Figura 1 - Julgamento realizado nas Ilhas Sandwich Fonte: Arago (1823, t.II, p.137)

A imagem exerce uma função integrada ao texto das cartas, de modo que os métodos de implementação de justiça elaborados pelos sandwichiens são duramente criticados. Arago inclusive estabelece uma diferença entre os habitantes das Ilhas Sandwich e as tribos 
brasileiras: as últimas seriam momentaneamente indulgentes com seus prisioneiros, causando-lhes prazeres de forma que estes viessem a sentir mais remorso perante a perda da vida (Arago, 1823, t.II, p.137). As tribos brasileiras seriam, portanto, mais perversas.

Entretanto, o mesmo tema é abordado no romance Souvenirs d'un aveugle contendo uma ressalva, na qual Arago reitera que a verdadeira harmonia e a verdadeira igualdade não se encontram acessíveis em nenhum lugar do mundo senão nos cemitérios:

Indique-me então lugares onde a perfeita igualdade seja compreendida e posta em prática! Tal lugar existe, no entanto: são os cemitérios, os pântanos de todas as regiões do mundo. Glória, grandeza e esplendor por fora, é verdade; mas, por dentro, pó de escravo ou de senhor, pó de idiota ou de homem de gênio: igualdade perfeita. Nesse sentido, portanto, tudo é harmônico no desacordo físico e moral das Ilhas Sandwich. (Arago, 1868, p.233) ${ }^{25}$

A compreensão de uma gama tão vasta de representações, tanto literárias quanto iconográficas, produzida pelo mesmo agente se torna mais factível mediante a relação com as formulações de Chartier, para quem as representações "são sempre determinadas pelos interesses de grupo que as forjam. Daí, para cada caso, o necessário relacionamento dos discursos proferidos com a posição de quem os utiliza" (Chartier, 1990, p.17). Sendo assim, as representações devem ser concebidas dentro de dinâmicas sociológicas que permitem novas reformulações e apropriações mediante os deslocamentos dos agentes em função de seus sucessivos posicionamentos sociais ocupados. É possível inferir que Jacques Arago cunhou representações mais severas em torno dos indígenas americanos, as quais tinham como

25 "Indiquez-moi donc des lieux où la parfaite égalité soit comprise et mise en pratique! Il y en a pourtant: ce sont les cimetières, les moraïs de tous les pays du monde. Gloire, grandeur et faste au dehors, cela est vrai; mais au dedans, poussière d'esclave ou de maitre, pussière de crétin ou d'homme de génie: égalité parfait. Ainsi, donc, tout est harmonie dans le désaccord physique et moral des iles Sandwich." 
base sobretudo o ideal de civilização oriundo do campo da História Natural. Também concluímos que seu próprio posicionamento social se encontrava estreitamente vinculado ao desenvolvimento das atividades de Estado da Restauração Bourbon, tal como identificados em sua designação enquanto desenhista de uma expedição científica de volta ao mundo, legitimada não só pelo rei, mas também pela Academia Real de Ciências da qual seu irmão fazia parte.

Os textos analisados também podem ser compreendidos a partir da historicidade dos gêneros textuais. Os diversos gêneros emulados por Arago, tais como a narrativa epistolar e o próprio relato de viagem, são variáveis ao longo do tempo, e sua apreensão pode ser viável não mediante a comparação de tais produções a algum tipo de formulação essencialista referente ao que seria - um modelo primordial de narrativa epistolar, por exemplo -, mas sim através da comparação com obras produzidas no mesmo período. Portanto, a contínua transformação histórica dos gêneros pode ser compreendida através da comparação de várias formas de ativação de um certo gênero na cultura de uma época, sem que seja tido como parâmetro principal da possibilidade de eficácia de tais produções à semelhança de um suposto modelo ontológico, primordial e imutável do que supostamente deveria ser, por definição, o gênero (Schaeffer, 1989).

Um texto que possibilita uma boa comparação entre gêneros é o relatório científico produzido por Louis de Freycinet, comandante da expedição da qual Jacques Arago fez parte. Tanto Freycinet quanto Arago compartilharam experiências semelhantes em função da viagem e do contato com as regiões do itinerário da expedição. A escrita de seus relatos, no entanto, também é condicionada pela moldura dos gêneros. A forma como os índios são descritos na série de cartas e nos romances de Arago é diferente da forma como, à mesma época, Freycinet descreveu os nativos brasileiros, por exemplo.

O relatório de Freycinet referente ao Rio de Janeiro foi publicado em 1825, cinco anos após a realização da viagem. O documento confirma a análise de trabalhos historiográficos que ressaltam o catolicismo de Freycinet e seu apreço pela ação missionária dos jesuítas (Taillemite, 1999, p.489)-apreço que resultou em divergências com 
o caráter crítico e por vezes anticlerical do próprio Jacques Arago (Benoît-Guyod, 1942, p.48-49). Freycinet narrou a história política da região e descreveu os usos da natureza efetuados tanto pelos colonos quanto pelos nativos, além de atributos geográficos, a flora e a fauna locais. Ao se ater às formas pelas quais os nativos se relacionavam com a natureza, o viajante francês se alinha a uma tradição de análise que remete às formulações de Buffon. Essa, porém, não é a maior especificidade de seu texto, mas sim o cristianismo, outro eixo primordial de sua análise das comunidades tradicionais fluminenses.

Os índios ocupam um capítulo à parte no relatório e são descritos mediante o uso da categoria "civilização". Assim, a distinção efetuada por Freycinet entre povos não se resume à diferenciação entre povos nativos e povos de origem europeia. Freycinet diferencia os povos indígenas originais e os povos indígenas vivos à época de sua expedição. Essa operação permite que ele reconheça, no período em que visita o Rio de Janeiro, a presença do que chama de "índios civilizados", "índios semicivilizados" e "índios ainda selvagens" (Freycinet, 1825, p.324).

Os índios civilizados seriam basicamente aqueles há mais tempo convertidos ao cristianismo, os quais estariam concentrados principalmente nos entornos da capital, nas vilas de San Lorenzo, San Gonçalo e Sepatiba. Há, portanto, novamente o elogio à catequização promovida pelos jesuítas, a qual teria tornado os costumes dos índios menos ferozes e introduzido o hábito do trabalho e a prática de artes mecânicas nesse grupo (ibid., p.324). Os índios civilizados se apresentariam, no entanto, em pouca quantidade, sobretudo pelo fato de já estarem demasiado mesclados com os portugueses. Freycinet se apropria dos textos de Eschwege e do príncipe de Wied-Neuwied ${ }^{26}$

26 É possível identificar, aqui, um descompasso entre os textos de Freycinet e aqueles dos quais se apropria, tendo em vista que o príncipe Maximiliano de Wied-Neuwied, ao analisar as diferentes tribos e raças, tinha como referencial principal seu professor, Blumenbach, o qual classificou as raças humanas tomando como referencial principal a fisiologia (notadamente os diferentes formatos cranianos), ao passo que, como demonstrado, a análise de Freycinet acerca dos grupos indígenas se baseia predominantemente em uma concepção 
para descrever traços físicos desses índios, como a estatura média e a pele avermelhada, bem como características de suas habitações feitas de pedaços de madeira entrelaçados e guarnecidas com argila, com telhados em folhas de coqueiro. No que diz respeito à relação com os costumes portugueses, há críticas, ainda que se impute aos índios o título de civilizados. De acordo com Freycinet (ibid., p.325-7), esses índios, aparentemente, ainda estariam em um nível forte de superstição e ignorância, desfigurando algumas práticas e crenças da religião a eles apresentada. Os índios semicivilizados, por sua vez, estariam presentes às margens do rio Paraíba, nas aldeias de San-Fidelis e Aldeia da Pedra, aldeias de Coropó e Coroado. Freycinet lamenta que, em meio a esses índios, nenhuma indústria europeia tenha se estabelecido eficazmente. Em relação às doenças averiguáveis no grupo dos Coroado, Freycinet cita a diarreia, a icterícia e a tuberculose, e critica os costumes de cura empregados por esses grupos, sobretudo em relação a febres e ao sarampo, curados somente mediante a imersão do doente na água fria. A poligamia dos Coroado também é criticada (ibid., p.329-332). Em relação aos índios não civilizados, ele registra poucos dados, sob a justificativa de que eles teriam sido analisados por poucos historiadores e viajantes. $\mathrm{O}$ grande apoio que Freycinet encontra ao se apropriar de outros relatos de viagem para analisar certos grupos indígenas permite a inferência de que a expedição teve pouco contato direto com esses grupos, acumulando pouco material decorrente de experiências próprias.

Assim como Jacques Arago, Freycinet também foi intensamente marcado pelo contato com diferentes povos ao longo de sua viagem. Tais marcas o levaram a escrever sobre os povos ditos "selvagens" em momentos posteriores de sua vida, sem se restringir à incumbência da publicação de um relatório científico. Em junho de 1840, já membro da Academia de Ciências, o comandante explicita ainda mais sua

de civilização vinculada aos modos de subsistência e relação com a natureza. Para detalhes em torno de Wied-Neuwied e sua relação com os textos de Blumenbach, ver Costa (2008, p.10-11). 
adesão a um programa específico de compreensão não só desses povos como da própria história humana:

Quando consideramos com cuidado os costumes, a indústria e a religião dos homens não civilizados, identificamos curiosas semelhanças com o pensamento dos mais antigos povos cujos usos e crenças a história nos transmitiu. Essas observações tendem a demonstrar a grande unidade da espécie humana e as comunicações que os homens outrora estabeleceram entre si, em uma época remota da qual os livros e a tradução igualmente perderam a lembrança, mas da qual a analogia nos fornece ainda provas irrefutáveis. (Freycinet, Annales maritimes, 1840, t.II, p.917 apud Taillemite, 1999, p.492 $)^{27}$

A religião mais uma vez surge como categoria cara às formulações de Freycinet. Desta vez, no entanto, certos traços das crenças e práticas selvagens são interpretadas como evidências de uma unidade da religiosidade humana:

São, convenhamos, fatos notáveis encontrar o dogma da imortalidade da alma exatamente em meio aos povos que consideramos localizados no último estágio da escala intelectual, ver que a ideia de um espírito mau e a de uma potência recompensadora existem em meio a eles, e que quase em todos os lugares ainda eles conservam a tradição do dilúvio e em muitos pontos traços evidentes da lei mosaica. (Freycinet, Annales maritimes, 1840, t.II, p.917 apud Taillemite, 1999, p.492) $)^{28}$

27 No original francês: "Quand on considère avec soin les moeurs, l'industrie et la religion des hommes non civilisés, on y remarque de curieuses similitudes avec les pensées des plus anciens peuples dont l'histoire nous ait transmis la croyance et les usages. Ces observations tendent à demontrer la grande unité de l'espèce humaine et les communications que les hommes ont eues entre eux à une époque reculée dont les livres et la traduction ont également perdu le souvenir mais dont l'analogie nous fournit encore des preuves irréfragables".

28 No original francês: "Ce sont, on en conviendra, des faits très remarquables que de retrouver le dogme de l'immortalité de l'âme jusque chez les peuples que nous considérons comme placés au dernier degré de l'échelle intellectuelle, de voir que l'idée 
O campo científico do qual Freycinet fez parte também possibilitou a produção de outras representações de indígenas. Muitos outros relatórios científicos registraram até mesmo um sentimento de compaixão pelos índios, tal como o fizeram muitos românticos quando descreveram os negros escravizados. Auguste de Saint-Hilaire, por exemplo, chegou a lamentar sua própria previsão do eminente fim dos Indiens du Brésil [Índios do Brasil] (Potelet, 1993, p.225). A literatura de viagem, contudo, não se restringiu ao campo científico, e dentre os viajantes que optaram por registrar os índios brasileiros de maneira apologética, Ferdinand Denis é, certamente, um dos que mais se destaca.

Ele esteve no Brasil pela primeira vez em 1816, residindo primeiramente no Rio de Janeiro e, em seguida, na Bahia. Sua viagem foi motivada sobretudo pelas más condições financeiras em que sua família se encontrava, tendo em vista que seu pai havia perdido toda sua fortuna ao longo da Revolução, além de seu irmão ter sido prejudicado com a Restauração de 1815 (Potelet, 1993, p.26). Após deixar o Brasil, Denis escreve diversas obras sobre o país, tais como Le Brésil ou histoire, moeurs, usages et coutumes des habitants de ce royaume [Brasil, ou história, hábitos, usos e costumes dos habitantes desse reino], junto a Hippoltyte Taunay, em 1822, e Histoire géographique du Brésil [História geográfica do Brasil], publicada em 1833. A experiência de quatro anos no Brasil bem como um amplo mercado europeu de interesse por bens exóticos - tais como livros, objetos, quadros, artefatos indígenas e até mesmo animais empalhados - permitiram que Denis, ao retornar à França em 1820, pudesse de fato ingressar no campo intelectual, nele se consolidando mediante diversas estratégias narrativas e editoriais (Daher, 2012, p.192-193).

Denis integrou o projeto de autonomização da literatura brasileira frente à literatura portuguesa, sobretudo mediante a publicação, em 1826, de Résumé de l'histoire littéraire du Portugal suivie du resumé de

d'un malin esprit et celle d'une puissance rémunératrice existent partout au milieu d'eux, que presque partout encore ils conservent la tradition du déluge et sur beaucoup de points des traces évidentes de la loi mosaïque". 
l'histoire littéraire du Brésil [Resumo da história literária de Portugal seguida do resumo da história literária do Brasil]. Suas representações, de caráter apologético e nacionalista, transformaram as "cenas" da natureza tropical, bem como os temas indianistas, em objetos de uma literatura efetivamente brasileira. Seu trabalho foi posteriormente apropriado por muitos brasileiros que se debruçaram sobre a questão indígena. Um exemplo é o general Couto de Magalhães que publicou, em 1876, O selvagem: trabalho preparatório para aproveitamento do selvagem e do solo por ele ocupado no Brasil, um programa de civilização para os índios (Daher, 2012, p.170, 188-189). É possível identificar, portanto, diversas linhas de intertextualidade entre a vasta obra de Denis e a de vários autores.

A intertextualidade entre os textos de Ferdinand Denis e os primeiros escritos de Jacques Arago é evidenciada na obra Scènes de la nature sous les tropiques [Cenas da natureza sob os trópicos]. Publicada em 1824, Scènes de la nature menciona o recém-publicado relatório científico de Louis de Freycinet, além da série de cartas de Arago (Denis, 1824, p.15, 221, 359). Os textos são apropriados por Denis no intuito de demonstrar a especificidade das cenas nos trópicos. Na obra, são vários os aspectos de um programa romântico que permite sua vinculação à linhagem textual que inclui Alexander von Humboldt, Chateaubriand e Bernardin de Saint-Pierre. Denis se aproxima de uma formulação da possibilidade de cognição da natureza tal como concebida por Humboldt, na qual paisagens, costumes e inspirações poéticas se tornariam apreensíveis para o viajante mediante a experiência - o que permite uma analogia entre as Scènes de la nature, de Denis, e as Ansichten der Natur [Visões da natureza], de Humboldt (Daher, 2012, p.194-199). Em função disso, no tocante à representação dos indígenas, eles são descritos sempre com base em uma referência à paisagem: mediante o uso da fórmula da "convergência do olhar" do viajante. No capítulo VIII, "Amor do indígena pelas suas florestas: efeitos que devem produzir sobre ele nosso clima”, Denis recupera um caso descrito em edição 
do Journal de Débats, ${ }^{29}$ no qual constaria a narrativa de um índio botocudo que, levado a Viena, não teria suportado a vida em meio à civilização, reclamando seu lugar e sua integração harmoniosa às florestas tropicais (Denis, 1824, p.61-65). É sobretudo no capítulo XVIII, dedicado aos índios Machakali, que Denis evidencia sua adesão a uma representação romântica dos indígenas, lamentando o desaparecimento das "nations" brasileiras e de sua história. Segundo o francês, tribos como os Guaycourou, os Machakali e os ferozes Aymoré não teriam recebido dos viajantes europeus a mesma atenção conferida àqueles que outrora habitaram o Canadá e a Flórida. Denis lamenta o sacrifício de "cem nações ainda na inocência, sacrificadas pelo amor a riquezas, e a verdadeira coragem vencida pelos mais negros artifícios" (Denis, 1824, p.130-131). ${ }^{30}$

Denis não teceu comentários de tal teor apenas em Scènes de la nature. Em Histoire géographique du Brésil, um ensaio em torno da falta de conhecimento, por parte dos europeus, acerca do interior do território brasileiro, também traz comentários semelhantes. $\mathrm{Na}$ obra, é possível encontrar descrições de indígenas nas quais Denis exalta a coragem e os caracteres nobres das nações nativas brasileiras. Para tanto, recupera as descrições efetuadas por Jean de Léry, viajante guenote que no século XVI teria sido, segundo Denis, o primeiro a descrever com cuidado tanto as produções naturais da região brasileira como tais nações até então desconhecidas. Somente através de Lery foi possível, para a cultura europeia da época, uma compreensão plena dos nativos americanos, não mais mediada pelos contos de homens como Munster que, nas palavras de Denis, teriam descrito os índios de maneira absurda, efetuando julgamentos que não eram exatos nem isentos de preconceitos (Denis, 1834, p.7).

29 De acordo com o historiador Jean-Claude Caron, o Journal des Débats seria uma publicação de caráter combativo no contexto político francês, vinculada aos "ultrarroyalistes", grupo entusiasta da radicalização dos valores monárquicos em disputa sob o governo de Luis XVIII (Caron, 2011, p.12). Ferdinand Denis, contudo, não se manifesta acerca do caráter da publicação.

30 No original francês: "cent nations encore dans l'innocence sacrifiées à l'amour des richesses, et le vrai courage vaincu par les plus noirs artifices". 
Apesar da intertextualidade, a obra de Denis se afasta do teor da análise referente aos índios cunhada por Arago na década de 1820, em sua série de cartas. O teor dos textos de Denis é sempre complacente em relação aos índios. Denis, ao recordar os selvagens brasileiros levados por Claude d'Abbeville para serem expostos na Europa, ressalta que os mesmos "morreram de dor longe de suas belas florestas" (Denis, 1834, p.8). Ao estabelecer um quadro histórico do desenvolvimento das raças brasileiras, o viajante francês também reconhece que, pouco a pouco, as raças indígenas viriam perdendo os costumes de seus instintos primitivos. Além disso, ao discorrer sobre o destino da nação, Denis não critica a presença indígena ou condena o desenvolvimento do território em função dela. O Brasil em sua totalidade, o que incluiria todas as raças citadas por Denis, ou seja, inclusive os índios, apresentaria todos os atributos necessários para a sua ascensão entre os povos (Denis, 1834, p.92).

As semelhanças entre Denis e Arago não se restringem às suas formulações textuais. Ambos os escritores se dedicaram à coleta de bens exóticos, o que incluia diversos artefatos indígenas. Tal espécie de colecionismo pode ser considerada parte constitutiva de uma verdadeira "economia de bens exóticos", a qual motivou diversas trocas e redes entre grupos franceses, sobretudo devido a uma "longa tradição cultural francesa representada tanto pelos gêneros contidos no que se convencionou chamar 'literatura geográfica', quanto pelos gabinetes de curiosidades" (Daher, 2012, p.190-191).

A inserção de Jacques Arago em tal economia de bens exóticos está registrada em remissivas que enviou a d. Pedro II. Em carta de 16 de outubro de 1850, o viajante, além de solicitar uma permissão para dedicar seu próximo romance a d. Pedro II, também solicitava uma medalha da Ordem do Cristo, afirmando tê-la recebido da mãe do imperador à época de sua primeira viagem pelo Brasil, acompanhando Freycinet, tendo, no entanto, perdido tal medalha ao longo de uma aventura marítima. Como dito anteriormente, seu último romance, Les Deux Océans, foi dedicado ao imperador. No intuito de obter a permissão para realizar tal dedicatória, Jacques Arago ofereceu, em troca, parte dos bens exóticos que possuía. Artefatos 
produzidos por comunidades tradicionais integravam seu acervo pessoal, o que denota a forma como o viajante lhes imputava um valor exótico. Dentre os objetos, constavam as armas de dois reis do Arquipélago das Marquesas, arcos e flechas da Nova Caledônia e uma coroa tecida pela rainha tahitiana Pomaré. ${ }^{31}$

Ainda no tocante às representações literárias, é possível afirmar que, em uma questão, tanto Ferdinand Denis como Jacques Arago registraram apreensões de fato muito semelhantes: a prodigalidade da natureza brasileira. Denis (1834, p.22) afirmou que, no Brasil, a natureza apenas espera que o homem peça algo, sempre dando a ele o que é pedido. Já Arago chegou a registrar que o homem seria sempre jovem nas terras do Rio de Janeiro: Deus não teria dado ao homem brasileiro o tempo de envelhecer. Os dias no Brasil seriam isentos de dor e arrependimentos. Tais concepções estão registradas em uma das últimas obras de Arago, Voyage autour du monde sans la lettre A [Viagem ao redor do mundo sem a letra A], publicada em 1853 (Freitas, 1996, p.28-29). Essa obra, portanto, denota uma mudança nas preferências do autor em relação às possibilidades de representação do Brasil, as quais se tornaram semelhantes às cunhadas por Ferdinand Denis cerca de vinte anos antes.

A exaltação do estado da natureza em tal perspectiva, que remete indubitavelmente às formulações de Jean-Jacques Rousseau, certamente se tornou disponível para ambos devido à adesão enfática, anos antes, de outro viajante e naturalista: Bernardin de Saint-Pierre. Ainda no século XVIII, Saint-Pierre atuou como naturalista na administração colonial da ilha Maurício, junto a Pierre Poivre e Philibert Commerson, botânico que acompanhou o viajante Bougainville em expedição de volta ao mundo (Grove, 1995, p.216). Posteriormente, já ao longo do período revolucionário, chegou a ficar encarregado, no ano III, do curso de Ciências Morais na École Normale. Suas obras tiveram grande repercussão na cultura científica europeia da época e contribuíram para uma difusão da imagem dos trópicos e sobretudo

31 Documento do Arquivo da Casa Imperial do Brasil. Maço 113 - Doc. 5662. Acervo Arquivo Histórico/Museu IMperial/Ibram/MinC. 
das ilhas tropicais enquanto locais virtuosos, onde seria possível uma vida em comunhão com a natureza. Exemplo emblemático de tal concepção é o romance Paul et Virginie (Freitas, 1996, p.40-41; Kury, 2001a, p.42).

Já nas cartas publicadas após a viagem junto a Freycinet, Jacques Arago registra seu apreço aos textos de Bernardin de Saint-Pierre, filiando-se, então, a uma tradição literária simbolizada pelo autor. Ao visitar a Ilha de França, o viajante oitocentista lamenta o fato de sua experiência com o local se contrapor às imagens tecidas no romance do naturalista do século XVIII.

Os nomes do Grande Rivière, Rivière Noire, Piterboth, Pamplemousses e Rivière des Lataniers, lugares atraentes, celebrados pela musa de Bernardin de Saint-Pierre, e os quais excitaram o interesse de minha juventude, despertaram em mim uma curiosidade que eu não poderia deixar de corresponder. Paul e Virginia, eu estava prestes a lhes acompanhar em suas caminhadas, a lhes seguir nas ravinas, a perambular junto a vocês ao pé das Trois Mamelles, a lhes assistir cruzando a corrente, visitar suas cabanas no Enfoncement des Prêtres. Eu iria usufruir das carícias de suas ternas mães e contemplar com emoção as duas palmeiras, as quais remontavam aos seus nascimentos e iriam cair com vocês. Oh, por quê?! Por que tais ilusões devem ser destruídas? Por que Paul agora não passa de um ser imaginário aos meus olhos? Por queVirgina é apenas uma mera vítima desconhecida das ondas?! (Arago, 1823, t.1, p.129, grifos de Arago). ${ }^{32}$

32 Na tradução inglesa de 1823: "The names of Grande Rivière, Rivière Noire, Piterboth, Pamplemousses and Rivière des Lataniers, charming places, celebrated by the muse of Bernardin de St. Pierre, and which interested my boyhood, excited in me a curiosity which I could not forbear gratifying. Paul and Virginia, I was going to accompany you in your walks, yo follow you into the ravines, to stroll by your side at the foot of the Trois Mamelles, to assist you in recrossing the torrent, to visit your cottages in the Enfoncement des Prêtres. I was going to enjoy the caresses of your tender mothers, and to comtemplate with emotion the two palm-trees, which dated from your birth and were to fall with you. Why, alas! must such sweet illusions be destroyed! Why is Paul now but an imaginary being in my eyes; why is Virginia merely an almost unknown victim of the waves!". 
A filiação de Arago à obra de Saint-Pierre não se limita à citação do romance Paul et Virginie. A forma como o desenhista caracterizou, em seus últimos escritos, a virtude dos americanos, negando uma barbárie inata, também denota o vínculo. Na obra Études de la nature [Estudos da natureza], Bernardin de Saint-Pierre afirma que a barbárie é apenas uma doença da infância das nações, e não um atributo que faça parte da natureza humana. A barbárie seria apenas uma reação ao mal provocado por inimigos. Nesse sentido, o naturalista afirma na obra que se, por um lado, as ditas hordas selvagens do Novo Mundo comem reciprocamente seus prisioneiros de guerra, por outro lado, as famílias de um mesmo povoado vivem na mais perfeita união. No intuito de retirar de tal observação uma possibilidade de assertiva científica sobre as harmonias e semelhanças naturais como um todo, Bernardin de Saint-Pierre estabelece então uma comparação entre tal tipo de comportamento e aquele dos animais frágeis, os quais seriam muito mais vingativos que os maiores. Assim, o naturalista compara o comportamento de abelhas, as quais rapidamente ferroam a mão que delas se aproxima, ao passo que os grandes elefantes raramente alteram seu caminho quando próximos ao disparo de flechadas. Tendo isso em vista, seria a fragilidade dos nativos, portanto, que os levaria a tais atos violentos, e não uma crueldade inata (Saint-Pierre, 1804, p.438).

Em seus Études de la nature, Bernardin de Saint-Pierre também discorre sobre o gênero humano enquanto evidência da Providência Divina. O objetivo principal do autor seria responder àqueles que, com base nas diversas formas do gênero humano e nos males decorrentes de suas instituições, buscariam refutar as evidências da Providência divina, negando que os humanos possuiriam a mesma origem, além de uma superioridade de ordem moral em relação às bestas (Saint-Pierre, 2007, p.177). Jacques Arago, embora não teorize sobre uma origem comum do gênero humano tal como Saint-Pierre, arrisca em sua série de cartas inferir sobre uma remota origem comum de tribos que encontrou. Mais uma vez, mediante uma reflexão do que é ser viajante, Arago, após citar as tribos brasileiras dos Jumma, Mauhe, Pamma e Parintintin, as compara àquelas presentes em ilhas da Polinésia, afirmando: 
Nós poderíamos talvez, então, encontrar alguns pontos de aproximação entre nações tão distantes: e quanto a mim, eu não posso deixar de pensar que um viajante, que deve dirigir sua atenção exclusivamente aos pontos de semelhança existentes entre os povos separados uns dos outros pelo diâmetro do globo, e que deveria conceber tal semelhança de forma consoante à razão e ao bom senso, abriria uma rica e útil mina, a qual um espírito filosófico e observador por sua vez trabalharia em prol da humanidade. Que muitas tribos anteriormente desconhecidas possam se assemelhar umas às outras em atributos de pouca importância é algo a ser facilmente concebido: mas que botocudos, por exemplo, apresentem tal coincidência, se assim posso me expressar, com os nativos das Carolinas, que os costumes dos mundrucus se assemelhem, quase que nas mínimas circunstâncias, aos dos neozelandeses, é um argumento para que eu acredite que, dia ou outro, poderemos encontrar aproximações entre essas diferentes nações, as quais, sem diminuir a fama de um Cook, um La Perouse, um Gama, um Colombo ou um Magella, possam tender a provar que essas tribos, agora tão afastadas, mas ainda assim tão intimamente semelhantes, estiveram sujeitas aos mesmos trajes, compartilharam as mesmas tarefas árduas, e foram separadas apenas por uma dessas catástrofes que abalaram a face do globo e alteraram as leis da natureza. (Arago, 1823, p.100-101) ${ }^{33}$

$33 \mathrm{Na}$ tradução inglesa: "We shall perhaps then find some points of approximation between nations so remote: and for my part, I cannot help, thinking, that a traveller, who should direct his attention exclusively to the points of resemblance existing between people separated from each other by the whole diameter of the globe, and who should account for the phaenomena of that resemblance in a manner consonant with reason and good sense, would open a rich and useful mine, which a philosophical and observant spirit would in is turn work for the benefit of mankind. That many insulated and formerly unknown tribes may resemble each other in the character of their countenance and in some general and unimportant features, may easily be conceived: but that the Botocudos, for example, should have such a coincidence, if I may so express myself, with the natives of the Carolines; that the customs of the Mundrucus should, almost in ther minutest circumstances, resemble those of the New Zealanders, is an argument with me for believing, that some day or other we may find approximations between these different nations, which, without diminishing the fame of a Cook, a La Perouse, a Gama, a Columbus, or a Magellan, 
Da exposição efetuada, é possível enfim elaborar algumas conclusões em torno das representações indígenas concebidas por Arago. Trata-se certamente de uma obra complexa, descontínua e por vezes contraditória, cujos elementos indicam, para usar as palavras de Pierre Bourdieu (1994, p.71), verdadeiras tomadas de posição (prises de position) de Jacques Arago que não se restringem nem à mera história da literatura de viagem, como tampouco a um mero contexto externo aos livros. Assim, suas produções acabam por emular diferentes possibilidades de representação dos indígenas. Mais do que uma fonte de acesso à realidade dos nativos americanos, tais representações são sobretudo registros que permitem a interpretação das formas através das quais a cultura europeia os compreendia. Destaca-se nos textos o uso da categoria "raça", sobretudo em sua vertente buffoniana, como um produto da história dos usos da natureza por parte de determinado grupo que se desenvolveram conjuntamente com o padrão moral dessa coletividade. A cultura romântica, por sua vez, é emulada no que diz respeito ao reconhecimento das individualidades e especificidades da trajetória de cada grupo social, especialmente mediante o reconhecimento do vínculo de seus costumes com a natureza e o local de suas origens. Não ocorre, todavia, uma ressignificação integralmente virtuosa de todo e qualquer grupo tido como "selvagem". As caracterizações mais rígidas e críticas em relação aos povos tradicionais americanos são frequentes, sobretudo nas representações criadas nos momentos em que Jacques Arago esteve mais intimamente vinculado a instituições do Estado francês, sendo, portanto, o resultado de disposições específicas oriundas de um dado posicionamento social, historicamente variável. Jacques Arago conheceu diversas comunidades indígenas em suas longas viagens de volta ao mundo. Os seus textos, no entanto, também refratam outra viagem: aquela que fez, social e estilisticamente, em seu próprio mundo, a turbulenta França do século XIX.

may tend to prove that these tribes, now so far asunder, but yet so closely resembling each other, have been subject to the same customs, have shared the same toils, and have been separated only by one of those catastrophes which have convulsed the face of the globe and changed the laws of nature". 


\section{Referências bibliográficas}

\section{Textos de época}

ARAGO, J. Comme on dîne à Paris. Paris: Berquet et Pétion, 1842. Disponível em: <http://books.google.com>. Acesso em: 30/7/2012.

Les Deux Océans. Bruxelles; Leipzig: Kiessling, Schnée et C, Libraires, 1854. 3t. Disponível em: <http://books.google.com>. Acesso em: $30 / 12 / 2012$.

Narrative of a Voyage Round the World, in the Uranie and Physicienne Corvettes, commanded by Captain Freycinet, during the years 1817, 1818, 1819, and 1820; on a scientific expedition undertaken by order of the French Government. In a series of letters to a friend. London: Treuttel and Wurtz, Treuttel, Jun. and Richter, 1823. Disponível em: <http://books.google. com>. Acesso em: 30/7/2012.

Souvenirs d'un aveugle, voyage autour du monde. Tome deuxième. Paris: Hortet et Ozanne, 1839. Disponível em: <http://books.google.com>. Acesso em: 30/7/2012.

Souvenirs d'un aveugle: voyage autour du monde. Paris: H. Lebrun Libraire, 1868.

DENIS, F. Histoire géographique du Brésil. Paris: [s/n], 1834. 2.ed. Disponível em: <http://gallica.bnf.fr/ark:/12148/bpt6k56517758>. Acesso em: 3/4/2013.

Scènes de la nature sous les tropiques, et de leur influence sur la poésie; suivies de Camoens et Joze Indio. Paris: Louis Janet, 1824. Disponível em: <http://gallica.bnf.fr/ark:/12148/bpt6k5714986t>. Acesso em: 20/3/2013.

FREYCINET, L. de. Voyage autour du monde, entrepris par Ordre du Roi, sous le Ministère et conformément aux instructions de S. Exc. M. le Vicomte de Bouchage, secrétaire d'État au Départament de la Marine, executé sur les corvettes de S.M. l'Uranie et la Physiciene pendant les annes 1817, 1818, 1819 et 1920. Paris: Pillet-Ainé, Imprimimeur-Librarie, 1825. Disponível em: <http:// gallica.bnf.fr/ark:/12148/bpt6k99353d>. Acesso em: 3/4/2013.

SAINT-PIERRE, B. de. Études de la Nature. T.IV. Paris: L'Imprimerie de Crapelet, 1804. Disponível em: <http://gallica.bnf.fr/ark:/12148/ bpt6k29316r>. Acesso em: 3/4/2013. 


\section{Livros, teses, artigos publicados em periódicos e textos de época republicados}

ARAGO, J. Jantares em diferentes países: esboço anedótico e fisiológico. Rio de Janeiro: José Olympio, 2006.

BANN, S. Romanticism in France. In: PORTER, R.; TEICH, M. (Eds.). Romanticism in National Context. Cambridge: Cambridge University Press, 1988.

BÉDEÏ, J.-P. La Plume et les barricades: de Lamartine à Baudelaire, les grands écrivains dans la révolution de 1848. Paris: Express Roularta Éditions, 2012.

BENOÎT-GUYOD, G. Au Temps de la Marine en bois: le tour du monde de "l'Uranie" (1817-1820) / le voyage triomphal de la "Belle Poule" (1840). Paris: Mercure de France, 1942.

BOURDIEU, P. Les règles de l'art. Genèse et structure du champ littéraire. Paris: Seuil, 1992.

Pour une science des œuvres. In: Raisons pratiques: sur la théorie de l'action. Paris: Seuil, 1994, p.59-89.

BOURGUET, M.-N. O explorador. In: VOVELLE, M. (org.). O homem do iluminismo. Lisboa: Presença, 1997.

CAPONI, G. Breve introducción al pensamiento de Buffon. Mexico: Universidad Autónoma Metropolitana, 2010.

CARON, J.-C. La France de 1815 à 1848. 2.ed. Paris: Armand Colin, 2011 [1993].

CHARTIER, R. A história cultural: entre práticas e representações. Lisboa: Difel, 1990.

CHINARD, G. L'Amérique et le rêve exotique dans la littérature française au XVIIe et XVIIIe siècle. Genève: Slatkine Reprints, 1970 [1913].

COSTA, C. R. d. O príncipe maximiliano de Wied-Neuwied e sua Viagem ao Brasil (1815-1817). Dissertação de Mestrado. Programa de Pós-Graduação em História Social do Departamento de História da Faculdade de Filosofia, Letras e Ciências Humanas da Universidade de São Paulo. São Paulo: USP, 2008.

DAHER, A. A oralidade perdida: ensaios de história das práticas letradas. Rio de Janeiro: Civilização Brasileira, 2012.

DUCHET, M. Anthropologie et histoire au siècle des Lumières. Paris: Albin Michel, 1995.

FOUCAULT, M. Les mots et les choses. Paris: Gallimard, 1966.

FREITAS, I. A. de. Pour une histoire naturelle de la géographie. Les voyageurs-naturalistes français au Brésil au siècle des Lumières. These de Doctorat en Géographie. Univeriste de Paris IV - Sorbonne. Paris: Sorbonne, 1996. 
GROVE, R. H. Green Imperialism: Colonial Expansion, Tropical Island Edens and The Origins of Environmentalism, 1600-1860. New York: Cambridge University Press, 1995.

GUSDORF, G. Les sciences humaines et la pensée occidentale IX: fondements du savoir romantique. Payot: Paris, 1982.

KURY, L. Histoire naturelle et voyages scientifiques (1780-1830). Paris: L'Armattan, 2001a.

. Viajantes-naturalistas no Brasil oitocentista: experiência, relato e imagens. História, ciências, saúde - Manguinhos, v.8 (suplemento), p.863-80, 2001b.

LEQUEUX, J. François Arago, un savant généraux. Physique et astronomie au XIXe siècle. Paris: EDP Sciences, 2008.

MEEK, R. Social Science and the Ignoble Savage. Cambridge/London/New York: Cambridge University Press, 2010 [1976].

POTELET, J. Le Brésil vu par les voyageurs et les marins français 1816 - 1840. Paris: L'Harmattan, 1993.

ROCHE, D. Humeurs vagabondes. De la circulation des hommes et de l'utilité des voyages. Paris: Fayard, 2003.

SAINT-PIERRE, B. de. Études de la nature. Présenté et annoté par Colas Duflo. Saint-Étienne: Publications de l'Université de Saint-Étienne, 2007.

SARDA, F. Les Arago: François et les autres. Paris: Tallandier, 2002.

SCHAEFFER, J.-M. Qu'est-ce qu'un genre littéraire? Paris: Éditions du Seuil, 1989.

SCHWARCZ, L. M. As barbas do imperador: dom Pedro II, um monarca nos trópicos. São Paulo: Companhia das Letras, 1998.

TAILLEMITE, É. Marins français à la découverte du monde: de Jacques Cartier à Dumont d'Urville. Paris: Fayard, 1999.

THOMAS, K. O homem e o mundo natural: mudanças de atitude em relação às plantas e aos animais (1500-1800). São Paulo: Companhia das Letras, 1996. 


\section{Parte III \\ Oralidade e universo cultural INDÍGENA}




\section{NARRATIVAS ORAIS E LÍNGUAS INDÍGENAS EM RORAIMA: EDUCAÇÃO E PRESERVAÇÃO DA MEMÓRIA E DO PATRIMÔNIO HISTÓRICO}

Ananda Machado*

\section{Introdução}

Para iniciar o texto, faremos breve retrospectiva sobre alguns de nossos momentos compartilhados na comunidade Tabalascada. Em 2009, fomos convidados para participar da Feira de Ciências da Escola Estadual Indígena Ednilson Lima Cavalcante, com varal de leitura e oficina de teatro de bonecos. Como nos foi solicitado, fotografamos e filmamos o evento. Em 2010, nos convidaram para realizar uma oficina de grafismo para uma futura exposição permanente nos muros da escola. No mesmo ano criamos o projeto de extensão "Narrativas orais: registros teatrais", quando algumas narrativas selecionadas pelos alunos e professores foram dramatizadas e filmadas. Em 2011, elaboramos um projeto de pesquisa e fomos selecionados no segundo Edital de Seleção de Pesquisas: a Preservação do Patrimônio Cultural no Brasil, com uma proposta de trabalhar as narrativas orais como estratégia de educação patrimonial.

Trataremos aqui principalmente do processo de pesquisa realizado durante um ano com a comunidade. A primeira reunião que

* Professora do Instituto Insikiran de Formação Superior Indígena, da UFRR, e doutoranda da UFRJ em História Social (PPGHIS). 
participamos depois da notícia da aprovação do projeto foi no dia 26 de maio, com o objetivo de ouvir os professores e demais interessados na comunidade em participar da pesquisa. O gestor da escola, Tênisson Raposo Felipe, abriu a reunião falando da importância do trabalho na coletividade e de "fincar" a prática educativa no que vivem.

Mesmo com muito debate e muitas iniciativas existentes, a questão do preconceito contra a própria cultura e identidade Macuxi e Wapichana na comunidade Tabalascada ainda é forte. Buscamos então com eles instrumentos para educação patrimonial que fortalecessem o uso das práticas culturais dentro da escola, com o objetivo de aproximá-la também da comunidade.

Listamos naquele momento os bens que os professores indígenas consideravam importantes de preservar: a história da comunidade; as crenças; o Parixara; as línguas macuxi e wapichana; as narrativas, as formas de processamento das manivas; os instrumentos musicais e os trançados. Para tanto, consideramos a seguinte definição de patrimônio:

Patrimônio é tudo o que criamos, valorizamos e queremos preservar: são os monumentos, as obras de arte e também as festas, músicas e danças, os folguedos e as comidas, os saberes, os fazeres e falares. Tudo enfim que produzimos com as mãos, as ideias e a fantasia. (Londres apud Iphan, 2012, p.5)

Ouvimos na ocasião, a exemplo do que já ocorreu em outras regiões de Roraima, reclamações sobre a falta de material didático específico sobre as culturas e nas línguas indígenas. Pontuei que poderia contribuir nesse processo de elaboração de materiais e afirmei que percebia o uso em si, o fazer cultural como material didático em si próprio, de modo que o movimento de sistematizar conhecimentos históricos de forma escrita ou audiovisual sobre o patrimônio macuxi e wapichana pudesse resultar em material pedagógico importante para o uso das escolas.

Refletimos ainda naquele momento sobre quais eram os resultados reais do ensino das línguas indígenas na escola e da necessidade 
da busca, pois, mesmo que o professor não saiba falar a língua do seu povo, é possível contribuir no processo de fortalecimento cultural. O desafio seria, conforme falou o professor Gerson: "transformar o dia a dia em ações de valorização cultural". Ele chamou atenção para a necessidade de quebrar o "muro invisível" entre a escola e a comunidade.

De acordo com as metodologias e classificações trabalhadas pelo Instituto do Patrimônio Histórico e Artístico Nacional (Iphan), há possibilidades de mapear com detalhes, inventariar e registrar os bens culturais que os professores listaram logo no início da pesquisa. Se assim for possível, de acordo com as formas até hoje trabalhadas pelo Iphan, no livro de registro de saberes caberiam: as histórias da comunidade (origem, conflitos vividos, causos etc.) e as crenças (conhecimentos associados às plantas que curam e orações). No livro sobre celebrações entraria o registro do Parixara, Tukui, Areruia (danças tradicionais indígenas). Já sobre formas de expressão seria abarcado as músicas e os instrumentos musicais; os trançados e as panelas de barro macuxi. No inventário da diversidade linguística caberia documentação das línguas macuxi e wapichana, além das narrativas (literatura oral). O livro de sistemas agrícolas locais contemplaria os processamentos da maniva, a diversidade de pimentas, sendo que o registro de uma referência poderia ser inscrita em mais de um livro.

E para que seja mantida a forma de organização social indígena desses povos, trabalhar no coletivo é fundamental, e o Iphan já atentou para essa questão. Por isso os materiais produzidos devem ser de autoria coletiva, sobretudo porque há muitos professores indígenas graduados em Licenciatura Intercultural da UFRR ou em outros cursos e faculdades. Eles possuem condições de escrever relatos e textos de conclusão de pesquisas por já terem vivenciado esses processos durante a formação.

Assim, o projeto teve a intenção de preparar os professores pesquisadores e também os jovens da comunidade nessa direção. A proposta foi pensada coletivamente e seria um avanço a possibilidade de trabalhar em coautoria com os professores e alunos indígenas. Em Roraima temos, de fato, pouquíssimos materiais publicados sobre 
culturas indígenas que poderiam ser usados nas escolas. Por isso, propomos uma oficina para trabalhar um roteiro a fim de organizar o material audiovisual que já tínhamos filmado desde 2009. A maior parte dos conteúdos vinha dos eventos que a escola promoveu, como: feira de conhecimento; participação em assembleias, encontros interculturais em outras comunidades, reuniões regionais, festas, como a da Damurida (prato indígena à base de pimenta), que acontece todos os anos desde a década de 1990 na comunidade Malacacheta (terra indígena vizinha), e registro das apresentações teatrais. Nas oficinas ainda não editamos, mas já planejamos também os materiais que precisamos ainda filmar e registrar.

Durante a reunião comunitária em junho e também na oficina para edição do material audiovisual, foram listados alguns problemas que a comunidade enfrenta, tais como: a piçarreira dentro da área indígena, o aterro do antigo lixão, os igarapés que não existem mais, a necessidade de reflorestamento com árvores tradicionais, o plantio da roça sem critérios prejudicando a mata ciliar, as pequenas barragens que provocam alagamentos, a plantação de acácias que contribui para assorear os igarapés. A partir dessas informações listamos narradores e lugares a serem visitados e filmados.

\section{Narrativas orais e conhecimentos históricos relativos ao território}

O estudo do arsenal teórico-metodológico do campo da história oral e da etno-história contribuiu para que pudéssemos nos organizar para trabalhar as histórias de vida de alguns senhores(as) na comunidade Tabalascada. Em especial, por conter narrativas coletadas inclusive em línguas indígenas na região, os livros de Koch-Grünberg nos ajudaram a compreender esses povos.

Na história do presente, o pesquisador é contemporâneo ao objeto que trabalha, que no fundo são os atores da história, compartilhando com eles categorias e referências comuns. Dessa forma, há proximidade entre os sujeitos da história, o pesquisador e, sobretudo, há 
perspectiva de emancipação, recuperação de memória e reafirmação de identidades. "A história oral tem uma função propriamente política de purgação da memória” (François apud Ferreira, 2006, p.12).

Esse aspecto nos interessou, em particular, porque muito do que vem sendo silenciado, quando lembrado, pode contribuir em processos de mudança e de libertação. Há possibilidade de escolha do que ainda é importante, de questionamento sobre o por quê caminham em tal direção.

O processo de tensão entre o uso do português e das línguas indígenas, das políticas de línguas, do conteúdo repassado nas escolas indígenas, das formas de interferência no destino, deixa consequências e marcas identitárias, evidenciando a história como um dos espaços privilegiados de desenvolvimento da construção de identidades (Ferreira, 2010).

Muitos argumentam que os povos indígenas deveriam escrever sua própria história como uma forma de controlar o seu próprio destino, mas enquanto houver antropólogos, historiadores, etno-historiadores, etnólogos e linguistas dispostos e preparados para cooperar com os indígenas, dentro da perspectiva desses grupos, registrando sua história, seus mitos e crenças, é válido o trabalho com especialistas, sobretudo se tal colaboração for por eles solicitada.

A transdisciplinaridade, respeitadas as especificidades de cada área de conhecimento, pode contribuir na direção de articular memória e história, conhecimentos indígenas e textos escritos por indigenistas, viajantes e missionários (destaque para o trabalho de dom Alcuino), textos em línguas indígenas e em português.

A memória é constituída a partir do presente e tem como função principal manter a coesão do grupo, identificando-o como uma "comunidade de memória" produzida, criada, como mostram suas narrativas. Cada pessoa, especialmente as mais velhas, requer para si o papel de guardiã da memória e o passado comum é recriado como estratégia de luta. E uma forma de conhecer essa diversidade e esse jogo de poderes é ouvir os que guardam a memória dos ancestrais, mas estes vêm enfrentando problemas em encontrar jovens interlocutores interessados e atentos. 
No dia 19 de setembro visitamos a casa de Célio Silvestre Cruz da Silva, de 61 anos, para ouvir e filmar suas narrativas em língua wapichana. Acompanhamos o professor Vítor Francisco Juvêncio, que coordenou esse dia de trabalho. Ele solicitou que Célio contasse da sua chegada na região, que se deu por volta dos anos 1980. Como não entendemos a língua, compreendemos apenas alguns assuntos dos quais falou e assim filmamos cerca de 30 minutos da fala dele. Como o objetivo da pesquisa era que os conhecimentos e línguas circulassem internamente na comunidade e escola, não foi grave o fato de não dominarmos ainda o idioma.

Em outra reunião na comunidade, listamos narradores que precisarão ser visitados (Atlas, Alderísio, Narciso, Silvestre e Maria), bem como os lugares que são importantes para eles e que deveremos visitar: olhos-d'água, igarapés (pontos para sobrevivência), mata com árvores centenárias, limites da terra indígena. As temáticas que abordaremos serão: literatura, alimentação (categorias), qualidade de vida na comunidade, educação no passado e no presente, suicídios que aconteceram na comunidade, a reza e sua importância, remédios caseiros, envelhecimento e expectativa de vida.

No dia 26 de setembro, viajamos de ônibus com dezessete alunos e Atlas, um dos moradores mais antigos da comunidade Tabalascada, que narrou suas experiências em relação aos lugares que percorríamos, no caminho que seguia em direção ao antigo lixão que a prefeitura de Cantá, nos anos 1997, construiu na comunidade.

Quando chegamos, Maria Rosita Ferreira Malaquias passava de bicicleta, uma macuxi que trabalhou durante 6 anos ali. Ela relatou a tristeza que viveu na época antes da demarcação e disse que crianças e moradores de outras comunidades e não indígenas vinham catar a carne desprezada, salgar e vender depois aos parentes.

Caminhamos até o local onde era jogado o lixo hospitalar. O material vinha de Boa Vista e ninguém sabia o que tinha naquelas embalagens, segundo Atlas, que só se lembra do mal cheiro e dos resíduos orgânicos contaminados que deixavam a população doente. $\mathrm{Na}$ época houve até surto de cólera. O gestor da escola, Tenison Raposo Felipe, que coordenou essa ação da pesquisa, contou que até hoje a 
comunidade não recebeu indenização pelos danos que sofreram e ainda buscam uma forma de recuperar o lugar, pois mesmo depois do aterramento persistem o odor ruim e o descampado provocado pelo desmatamento. A aluna Dáyra de Souza Silva falou em wapichana sobre a busca dos jovens pela preservação e recuperação dos lugares que sofreram impactos ambientais e culturais na comunidade.

Depois seguimos para a piçarreira, área desmatada e destruída pela mesma prefeitura. $\mathrm{O}$ aluno Andrews falou que acha importante as aulas acontecerem nesses lugares para que tenham consciência da luta pela expulsão desses exploradores e entenderem o que precisam fazer para proteger e recuperar o que for possível na terra indígena.

$\mathrm{Na}$ piçarreira, Atlas contou que retiraram tanto material dali sem a autorização da comunidade que construíram todo o asfalto, da BR até a sede do município de Cantá. O professor Gerson chamou a atenção para o fato de a área não poder mais ser recuperada, uma vez que vivencia um processo de erosão. Até hoje essa situação não foi resolvida, e os moradores não foram indenizados pelo impacto que sofreram com a exploração daqueles recursos de modo irresponsável.

D. Rosilda Raposo também gravou sua fala em macuxi sobre o que aconteceu no antigo lixão e triste, dessa vez em português, falou enquanto caminhávamos que os seres que protegem as matas estão sendo desrespeitados, que os jovens precisam conhecer sobre eles e retomar as histórias que repassam valores na relação com a natureza.

\section{O uso das línguas indígenas e os conhecimentos macuxi e wapichana}

Quando acordo pela manhã, minha cabeça não se encontra mais repleta do som dos ritmos de minha língua, como estava antigamente. Sua língua está aqui agora, fazendo-me pensar de forma estranha, forçando meus pensamentos a um ritmo estranho. Começo a esquecer como era. Todo dia sinto a minha língua escapulindo. As palavras que eram minha vida estão me deixando aos poucos. Estão voltando ao 
lar onde nasceram. Não consigo mais contar nossas histórias direito. (Doran, 1998 apud Crystal, 2005)

Há, então, necessidade de valorizar os conhecimentos indígenas manejados pelos mais idosos, registrados e transmitidos oralmente. Por isso o estudo histórico partiu desse movimento de ouvir os senhores da memória.

Nessa direção o uso das línguas indígenas merece atenção e precisa ser prestigiado, até porque há o que para ser lembrado precisa do conhecimento também da língua do povo. As línguas indígenas guardam nomes e conhecimentos que apenas quem fala e entende pode ter acesso, além disso, somos responsáveis por proteger e entender os processos sociais e de memória e esquecimento desses bens culturais que, além dos povos indígenas, são patrimônio da humanidade. E “a preservação das línguas é a parte dos direitos humanos e instrumento de autonomia política" (Franchetto, 2005).

Em uma das aulas que participamos, o professor Gerson lembrou que uma planta é apenas uma planta e que depende da relação para ela se tornar taja, por exemplo, e ser reconhecido seu espírito. "O elo com o sobrenatural precisa ser respeitado", afirmou o professor. Os alunos lembraram do texto que leram sobre as classificações das plantas, escrito por Nádia Farage.

A tese fala da ética da palavra sobre seres que protegem e nomeiam a natureza como os buritizais, awaruykuwaru, tynyz (redemoinho), arutynyz (avô veado mateiro), kuwitotynyz (avô calango), tynyz (o mais velho, o primeiro). Faltou, na ocasião, discutirmos em sala sobre o texto e os efeitos na comunidade do processo de desconhecimento dessas narrativas que protegiam o território pelo uso de nomes e pelos conhecimentos das histórias.

Os Wapichana, como os que conversaram com Farage, acreditam no mudo apelo das coisas através dos panaokarus (bicho, animal selvagem): "alma das coisas". Talvez a preservação do território no que se refere à biodiversidade tenha inclusive relação direta com os valores e nomes que as línguas indígenas transportam pela oralidade através dos tempos. 
As casas, com suas paredes, esteios, para os Wapichana possuem panaokaru (ou neles habitam os panaokarus dos materiais de que são feitos). "São como micróbios, você não vê, mas estão aí" (Ibid.). Talvez por isso os mais velhos tenham tanta preocupação diante da necessidade, por falta de matéria-prima, de construir casa de cimento e telha brasilit.

Se compararmos as matérias-primas da casa com a língua wapichana, talvez possamos ver a língua indígena como esteios da morada dos Wapichana. Talvez essa hipótese permita ver a língua indígena semeada dentro de cada um e pensar que basta usá-la, lembrar de sua história, para ela florescer e voltar a dar os frutos que sempre alimentaram a alma do povo Wapichana.

Defenderemos a hipótese da ligação da língua wapichana, por exemplo, com a alma desse povo. Sobre os valores que cercam a linguagem para os Wapichana, encontramos referência em Farage: "antes a palavra mudava as coisas. Tudo agora já está feito. [...] As batalhas verbais entre os demiurgos criavam as cachoeiras, rios, montanhas" (Farage, 1997, p.57). Assim os narradores wapichana contaram à autora. "A fala perdeu sua força produtiva [...] sua magia, hoje, só se manifesta no interior do discurso ritual” (ibid.). Na referida tese fica evidenciado o fato de que a fala articulada é o que faz os humanos. "Não humano é o que não fala" (ibid., p.58). Segundo os registros da autora, os Wapichana definem wa'uznao como nossa criação, o que evidencia que ainda é possível retomar ou recriar o rito e o potencial da fala.

Em nossa pesquisa, quando nos debruçarmos sobre as formas de construção do discurso e da memória, ficamos atentos também às questões linguísticas, pois "nas línguas amazônicas se encontram fenômenos que não se encontram em línguas de outras partes do mundo, ou então que aqui sejam mais frequentes fenômenos que são raros noutros lugares" (Rodrigues apud Quixalós, 2000, p.26). "Em alguns casos esses fenômenos exigem a revisão de pontos de teoria da linguagem antes propostos sem seu conhecimento" (ibid.).

O estudo de aspectos linguísticos aconteceu na pesquisa apenas quando apontaram algum aspecto cultural importante para o povo, o 
que aconteceu com frequência. Inventariamos, enfim, algumas particularidades linguísticas para que futuros estudos possam aprofundar cada questão.

Mas, se as políticas de desenvolvimento - ou a falta delas - continuarem a determinar a rápida extinção das línguas amazônicas, é mais provável que fenômenos raros ou únicos, mas de importância crítica para a melhor compreensão da linguagem humana, vão desaparecer sem sequer terem sido identificados. (Rodrigues apud Queixalos, 2000, p.26)

Se "a língua é uma força ativa na sociedade, um meio pelo qual indivíduos e grupos controlam outros grupos ou resistem a esse controle, um meio para mudar a sociedade ou para impedir a mudança, para afirmar ou suprimir as identidades culturais" (Burke, 1995, p.41 apud Freire, 2004), em Roraima esse campo ainda precisa ser mais trabalhado, as pesquisas históricas precisam problematizar mais a questão e estamos dispostos a continuar este estudo.

\section{Considerações finais}

Todo o processo de pesquisa foi interessante e conseguimos aproveitar desde os momentos mais difíceis, quando houve dificuldade de comunicação, até os mais prezerosos como o da subida na mata da Serra da Tabalascada.

Um dos pontos-chave para o trabalhoé a vontade da comunidade de falantes querer que sua língua permaneça. E foi daí que partiu nossa busca em realizar ações com os povos indígenas que possam contribuir nessa direção.

Há pouquíssimo material escrito nas línguas indígenas, esse fato em si já é indício da perda que os povos sofreram com o processo histórico vivido. Mas, por outro lado, percebe-se que muitas vezes a língua é um veículo indispensável para deslocar-se no tempo. 
Se o valor que os senhores Wapichana atribuem à palavra ainda é o descrito por Nádia Farage, acreditamos que remover do fundo dos rios de Roraima as falas lá adormecidas pode despertar muita lembrança, construir novos caminhos e contribuir para modificar os rumos da história.

Sabemos que a língua de muitos povos, com o assassinato da própria língua, se tornou a portuguesa. Mas se as comunidades reconhecerem o valor das línguas indígenas, elas poderão retomá-las e assim fortificar seu uso. Se a história não aconteceu da forma que gostaríamos, cabe a nós então reconstrui-la daqui pra frente.

\section{Referências bibliográficas}

CRISTAL, D. A revolução da linguagem. Rio de Janeiro: Jorge Zahar, 2005.

FARAGE, N. As flores da fala: práticas retóricas entre os Wapixana. Tese de Doutorado. São Paulo: USP, 1997.

FERREIRA, M. de M.; AMADO, J. (Orgs). Usos e abusos da história oral. 8.ed. Rio de Janeiro: Editora FGV, 2006.

FRANCHETTO, B. As línguas “em perigo” e línguas como patrimônio imaterial: duas ideias em discussão. Revista do Patrimônio Histórico e Artístico Nacional, Brasília, Iphan, n.32, 2005.

FREIRE, J. R. B. Rio Babel: a história das línguas na Amazônia. Rio de Janeiro: Atlântica, 2004.

INSTITUTO DO PATRIMÔNIO Histórico e Artístico Nacional (Iphan). Patrimônio cultural imaterial: para saber mais. 3.ed. Brasília: Iphan, 2012.

QUEIXALÓS, F.; LESCURE, O. R. As línguas amazônicas hoje. São Paulo: ISA, 2000.

RODRIGUES, A. D. Linguas brasileiras: para o conhecimento das línguas indígenas. 2.ed. São Paulo: Loyola, 1994. 


\title{
A COLONIZAÇÃO DA REGIÃO AMAZÔNICA: AS TRANSFORMAÇÕES DE UMA CULTURA APÓS O CONTATO COM A SOCIEDADE ENVOLVENTE ${ }^{1}$
}

\author{
Cláudia Nascimento Oliveira* \\ Kelli Carvalho Melo** \\ Adnilson de Almeida Silva***
}

As transformações sofridas pelos indígenas da Amazônia ao longo de séculos, após o contato com a sociedade envolvente, permanecem como a tônica de um processo que nos dias atuais, em decorrência do modelo econômico, assume um caráter de constantes intervenções. Os indígenas, por meio de estratégias de resistência e luta, procuram assegurar a permanência de suas culturas e a incorporação de novas representações e "valores" culturais, como é o caso dos Paiter Suruí. Todavia, em nome do desenvolvimento e do progresso o que se percebe é a dizimação das etnias ao longo de décadas.

1 Apoio MCT/CNPq, Projeto "Estudo das representações amazônicas: marcadores territoriais, culturais e socioambientais dos Paiter Suruís” - Edital MCT/ CNPq 14/2010 - Universal.

* Mestra em Geografia pela Unir, licenciada em História e pesquisadora do Grupo de Estudos e Pesquisas em Geografia, Mulher e Relações Sociais de Gênero Gepgênero. Docente do Departamento de Direito da Faculdade Uniron. E-mail: klaudiapvh@yahoo.com.br.

** Mestra em Geografia pela Unir, licenciada em Geografia e pesquisadora do Grupo de Estudos e Pesquisas Modos de Vidas e Culturas Amazônicas - Gepcultura.E-mail: kelli_geo@hotmail.com.

*** Mestre em Geografia pela Unir, doutor em Geografia pela Universidade Federal do Paraná (UFPR), pesquisador do Gepcultura e docente do Departamento de Geografia e do PPGG/Unir. E-mail: adnilsonn@gmail.com. 
A reflexão expressa em nosso trabalho objetiva demonstrar como essas questões são discutidas e compreendidas tanto pelos indígenas, quanto pela sociedade envolvente.

\section{Considerações iniciais}

A questão indígena no Brasil vem sendo discutida por muitos ainda que em círculos restritos por antropólogos, professores, acadêmicos, indigenistas e pela Funai. E, ao que parece, ainda há muito a ser debatido, se levarmos em conta as transformações das terras e aldeias indígenas ao longo dos anos.

O propósito deste trabalhoé fazer uma análise das transformações socioespaciais que o coletivo Paiter Suruí recebeu através do contato com a sociedade envolvente. A priori, abordaremos a chegada dos colonizadores à Amazônia e em seguida trataremos desta etnia em especial.

O trabalho é resultado de reflexões realizadas na disciplina Populações Amazônicas e Sustentabilidade, ministrada no Programa de Pós-Graduação em Geografia da Universidade Federal de Rondônia (Unir) e culminou no convite dos Paiter Suruí para que um docente e um grupo de discentes fossem participar de uma atividade ritualística em seu território.

Deste modo, a atividade foi realizada em agosto de 2011, na Aldeia Apoena Meireles, município de Rondolândia (MT), durante quatro dias, onde algumas apreensões resultaram em transformações no modo de vida dos Paiter Suruí, bem como a permanência de seus valores culturais, ainda que ressignificados. As considerações aqui expostas consistem das observações e entrevistas com a população indígena de várias aldeias que organizaram o ritual Mapimaí ou "criação do mundo".

Sabemos que o tempo para tal análise é muito breve, porém nossa proposição é oferecer um relato do que foi observado, destacando-se todo o histórico da luta dos indígenas em preservar as suas tradições. 
Iniciamos abordando a atuação do indígena no cenário que se formou com a chegada da sociedade envolvente em solos amazônicos. E em seguida trataremos dos Paiter Suruí.

\section{O papel do indígena na colonização da Amazônia}

Antes da chegada do colonizador, a Amazônia já era ocupada por inúmeras etnias indígenas, sendo que algumas viviam sob um governo monarca, semelhante aos dos incas, enquanto outras não possuíam governo centralizado. Onde hoje está localizada a Amazônia brasileira, existiam várias etnias com culturas distintas entre si, com línguas distribuídas nos troncos linguísticos tupi, aruak, karib, tucano, pano e jê.

Seus modos de vida permitiam uma integração com a natureza, isto é, conheciam a terra e seus segredos, sabiam onde e quando poderiam plantar e colher, caçar e pescar, construir suas malocas e realizar outras atividades no cotidiano. Entretanto, com a chegada da colonização, os modos de vida foram modificados, sendo que a ocupação portuguesa na região amazônica se deu no início do século XVII, com a fundação do Forte do Presépio, o que deu origem à cidade de Santa Maria de Belém do Grão-Pará.

A Amazônia foi ocupada inicialmente por exploradores luso-brasileiros, tropas de resgate, droguistas do sertão e por missões religiosas. Estas últimas tiveram participação significativa na ocupação espacial da região, que juntamente com as tropas de resgate portuguesas visavam caçar os indígenas e torná-los escravos das lavouras. As primeiras cidades a surgirem na região foram Belém, Bragança, Santarém, Óbidos e Monte Alegre.

$\mathrm{O}$ contato com o colonizador foi violento desde o início. $\mathrm{O}$ não indígena português precisava garantir as fronteiras contra os espanhóis e, para isso, era necessário expulsar e manter afastado o indígena que lutava contra esse avanço. Com isso, inicia-se o processo de "amansamento", tendo como consequência três formas de sujeição: os descimentos, os resgates e as guerras justas. Os chamados 
descidos eram aqueles livres e os resgatados e provenientes de guerras justas eram os escravizados legalmente. Os resgatados também eram chamados de "índio de corda", pois ficavam amarrados.

No início da colonização os indígenas eram usados como mão de obra escrava para atividades agrícolas, pecuárias, artesanais e de coleta de drogas do sertão. A precariedade do tráfico negreiro para a Amazônia, a ocorrência de epidemias e o chamado "boom do cacau" fizeram que a demanda de mão de obra crescesse ainda mais no século XVIII.

Os capitães deveriam zelar pela integridade do indígena, mas foram os que mais os exploraram. Os missionários que atuavam na Amazônia eram os carmelitas, os capuchinhos e os jesuítas. Os dois primeiros certa vez partiram para o confronto armado conta os jesuítas, pois se julgavam prejudicados com a divisão das terras. Os indígenas não tinham o direito de decidir se queriam ou não trabalhar. Os que estavam sem ocupação eram cedidos aos colonos que os "remunerariam", nem mesmo o direito sobre seus corpos tinham, visto que suas mulheres e filhas eram tomadas sexualmente pelos colonizadores.

Em 12 de maio de 1798 é criada a Carta Régia que acaba com o Diretório e obriga o indígena a fazer parte do Corpo de Milícias ou do Corpo dos Trabalhadores. Essa lei vigora até a independência do Brasil. Em 1808 e 1809, novas leis surgiram permitindo aos colonos a captura dos indígenas. No período da Regência esses atos foram revogados, e a partir de 1843 os capuchinhos iniciam o processo de catequização dos indígenas.

Ao analisarmos a ocupação da região amazônica vindo pelos rios Madeira, Mamoré e Guaporé, notamos que não houve muita diferença das demais regiões. Os colonizadores encontraram povos indígenas autóctones e oriundos de outros lugares, os quais haviam sofrido perseguições diretamente da colonização.

Os registros históricos mais antigos apontam que o Vale do Madeira era habitado pelos Tora, Mura e Matanawi, sendo os Mura os que mais reagiram à colonização portuguesa e acabaram se rendendo e pacificados por algum tempo. Porém, devido às agressões 
sofridas pelos "civilizados", voltaram a atacar na área do rio Madeira. No Vale do Tapajós, os Munduruku também não aceitaram facilmente a chegada dos portugueses, mas se tornaram seus aliados, porém com alto custo populacional, visto que sofreram diversas epidemias no final do século XVIII. No Vale do Guaporé, os escravos indígenas eram em menor quantidade em relação aos negros, o que era um diferencial em relação ao Rio Madeira e outras localidades.

A ocupação da região amazônica perduraria nos séculos XVIII e seguintes. Ocorre que em meados do ano de 1860 a região passaria por uma estagnação econômica quando o cacau e outros produtos exportados sofreram uma queda de preços. Somente com o primeiro ciclo da borracha, ainda no século XIX, houve um incremento econômico com o extrativismo, o que atraiu novos migrantes. Essa valorização da borracha permitiu o avanço de seringais nativos do Madeira, Mamoré, Guaporé, Purus e Juruá, o que resultou no "encontro de sociedades" entre trabalhadores e indígenas, de modo que os últimos foram as principais vítimas do processo exploratório.

Com o passar do tempo e com a queda das exportações da borracha, abranda-se a exploração dos indígenas, situação que muda com o segundo ciclo da borracha, quando é retomada com mais intensidade e prossegue mesmo após o fim desse período. Exemplo disso veio com a abertura das rodovias na década de 1960 e em seguida nas décadas de 1970 e 1980 com o surto migratório. De acordo com Scaramuzza (2010, p.155):

Os grandes projetos foram desencadeados em uma tentativa desesperada para alcançar os ritmos desenvolvimentistas dos países em ascensão e, assim, reduzir os supostos atrasos provocados pelo período colonialista brasileiro. A região amazônica, que outrora havia sido identificada como o inferno verde, foi magicamente transformada no grande paraíso terrestre, tornando-se palco de um dos processos migratórios mais intensos já ocorridos em território brasileiro.

Scaramuzza (2010) analisou a etnia Gavião, no entanto, é possível perfeitamente aproveitar sua pesquisa para contextualizar outras 
etnias, tendo em vista que em nada se diferem quando se trata de colonização e exploração. Todas sofreram por conta do acelerado crescimento que se buscava à época. A Amazônia começou a ser vista como a salvação do país. A região "passou a fazer parte dos grandes projetos desenvolvimentistas, aliando as estratégias de crescimento aos processos de colonização e avanço sobre o território" (ibid., p.155).

No caso rondoniense, a demanda de migrantes oriundos principalmente das regiões Sul e Sudeste, sedentos por oportunidades e iludidos com as propagandas governamentais, teve como consequência a mortalidade e extinção de várias etnias indígenas que viviam na região. O governo intensifica a propaganda de que é preciso ocupar a Amazônia, vista como um "vazio populacional”. Segundo Almeida Silva e Leandro (2010, p.56):

O governo Vargas, tido como o sinônimo de brasilidade e nacionalismo patriótico, pautou-se pela estratégia de marchar rumo ao oeste ocupando os vazios demográficos, confirmando a evidência empírica da baixa densidade demográfica. O mesmo percurso foi realizado por Juscelino Kubitschek durante seu governo quanto à política de ocupação do interior brasileiro, com a abertura de estradas que permitiam "levar o desenvolvimento" aos rincões mais distantes.

A desenfreada demanda de migrantes produziu uma depredação da natureza e transformou a cultura existente na região, conforme análise de Almeida Silva e Leandro (ibid., p.47):

todas as ações de ocupação e dilapidação do patrimônio "natural" e cultural da Amazônia obedecem a essa lógica do progresso e do desenvolvimento a qualquer custo, mesmo que isso represente a extinção da rica biodiversidade e dos povos tradicionais e indígenas.

Assim, de acordo com os autores, a região amazônica e seu povo transformam-se gradativamente em virtude da chegada do progresso. O povo indígena passa a desenvolver atividades que antes não exercia, 
"como trabalhadores rurais e urbanos sem quaisquer tipos de garantias e direitos trabalhistas, sujeitando-se a marginalização social” (ibid., p.52).

O contato da sociedade com os Paiter Suruí não difere do que ocorreu com outras etnias, com inúmeras mortes causadas pela violência ou por doenças pós-contato, o que levou-os praticamente à extinção. Não abordaremos tais questões aqui, pois nosso intuito com este trabalho é relatar a vivência e experiência no ritual Mapimaí.

\section{Etnia Paiter Suruí}

Como mencionado anteriormente, o trabalho com os Paiter Suruí deu-se em agosto de 2011 em função do convite feito pelos indígenas e como atividade de campo da disciplina em Geografia. A experiência foi realizada na autodenominada Terra Indígena Paiterey Karah. ${ }^{2}$

Nossa visita ocorreu durante a realização do ritual Mapimaí, cuja representação é a criação do mundo com o objetivo de transmitir conhecimentos e valores culturais para aos mais jovens da etnia Paiter Suruí, considerando que eles aos poucos vêm adquirindo novos significados em virtude do contato constante com a sociedade envolvente.

É importante salientar que o contato oficial foi feito pela primeira vez há pouco mais de quatro décadas. Antes disso, os Paiter Suruí haviam tido contatos esporádicos com extrativistas, logo, viviam de forma tradicional, sem qualquer interligação com a cultura da sociedade envolvente. Após o contato, ocorreram transformações, resultantes da influência externa, como percebemos ao longo dos dias em

2 Reconhecida pelo Estado brasileiro, a Terra Indígena Sete de Setembro está localizada nos municípios de Cacoal (RO) e Rondolândia (MT), com 248.146 hectares, e encontra-se situada entre $10^{\circ} 45^{\prime} 00^{\prime \prime}$ e $11^{\circ} 15^{\prime} 00^{\prime \prime}$ S e $60^{\circ} 55^{\prime} 55^{\prime \prime}$ e $61^{\circ} 25^{\prime} 13^{\prime \prime} \mathrm{W}$. Seu acesso se dá por via terrestre, a partir do sul, por linhas vicinais (caminhos do tempo da colonização) que começam na cidade de Cacoal, com numeração crescente $(8,9,10,11,12$ e 14) na direção leste, distantes cerca de $80 \mathrm{~km}$ uma da outra. A terra recebeu esse nome por conta do contato oficial com a Funai ter ocorrido em 7/9/1969. 
que estivemos na aldeia. Felzke (2007, p.15 apud Scaramuzza 2010, p.160) reforça essa nossa observação quando diz que,

A inserção no mundo dos brancos trouxe consigo mudanças na organização social, nos rituais tradicionais, nas relações com a natureza e no sistema econômico. Assim o capitalismo expresso pelo consumismo e pela necessidade constante de ganhar dinheiro passou a fazer parte no dia a dia das aldeias.

Os Paiter Suruí, assim como as demais etnias, após o contato com os colonizadores e com o seu modo de vida, passaram por um processo de aquisição das culturas envolventes, em que estas são ajustadas às já existentes, o que nos leva à reflexão de Claval (2001, p.13):

A cultura não é vivenciada passivamente por aqueles que a recebem como herança, eles reagem àquilo que lhes é proposto ou que se lhes pretende impor. Interiorizam certos traços e rejeitam outros. Inventam ao longo de suas existências, novas maneiras de fazer, atribuem cores novas aos seus sonhos e aos seus pesadelos e criticam os valores usuais quando estes não correspondem às suas aspirações profundas.

As mudanças após o contato, ao que tudo indica, foram muitas ao longo dos anos e vão desde a vestimenta até as construções das casas, que hoje são semelhantes às da cidade. Durante nossa estadia, observamos que havia duas malocas na aldeia, porém eram utilizadas apenas para a celebração dos rituais ou para abrigar os visitantes, não tinham o papel de moradia para os indígenas.

Toda a aldeia dispõe de energia elétrica. Foram construídos quatro banheiros de uso coletivo, sendo dois para o banho e dois com vaso sanitário. Não foi possível saber se os banheiros também são utilizados pelos moradores ou se foram construídos apenas para os visitantes, pois não tivemos acesso à parte interna das residências.

A espiritualidade também passou por novos significados e representações. Hoje não há somente a crença dos indígenas, há também a 
presença da Igreja evangélica na aldeia, a primeira a fazer contato com eles, uma realidade diferente da maior parte das outras etnias que, no Brasil, tiveram seu primeiro contato com a Igreja católica.

A presença do evangelismo está tão evidente que foi construída uma sede da igreja na aldeia para a celebração dos cultos, que nos serviu de abrigo nos dias que passamos na aldeia. Em conversa com os Paiter Suruí foi possível notar uma grande quantidade de adeptos ao evangelismo, fato que provoca conflito com os valores culturais e espirituais de ancestrais. A perda desses antigos valores é consequência do processo imposto pelas religiões não indígenas, já que possuem outras representações e códigos que não são facilmente aceitos pelos indígenas.

As fotos 1, 2, 3 e 4 a seguir retratam o modelo das casas, as malocas e a sede da igreja evangélica que estão edificadas na aldeia Apoena Meireles e demonstra o quanto esses símbolos antigos, além dos novos, refletem na organização espacial. Com a exceção da maloca ancestral, as demais edificações são formas que se contrapõem ao universo indígena paiter, mas que no atual estágio são compreendidas como uma "necessidade" para exprimir as relações com a sociedade envolvente. A maloca foi construída por conta do Mapimaí. Segundo informações dos participantes, a construção durou cerca de dois anos e após o ritual iria ficar como alojamento para os visitantes.

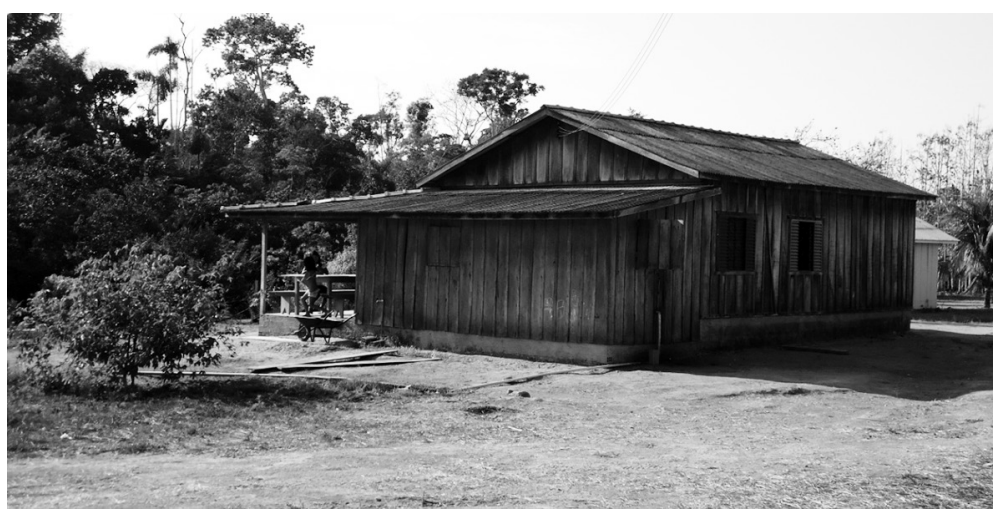

Foto 1 - Sede da escola infantil

Fonte: Cláudia Nascimento Oliveira, 2011. 


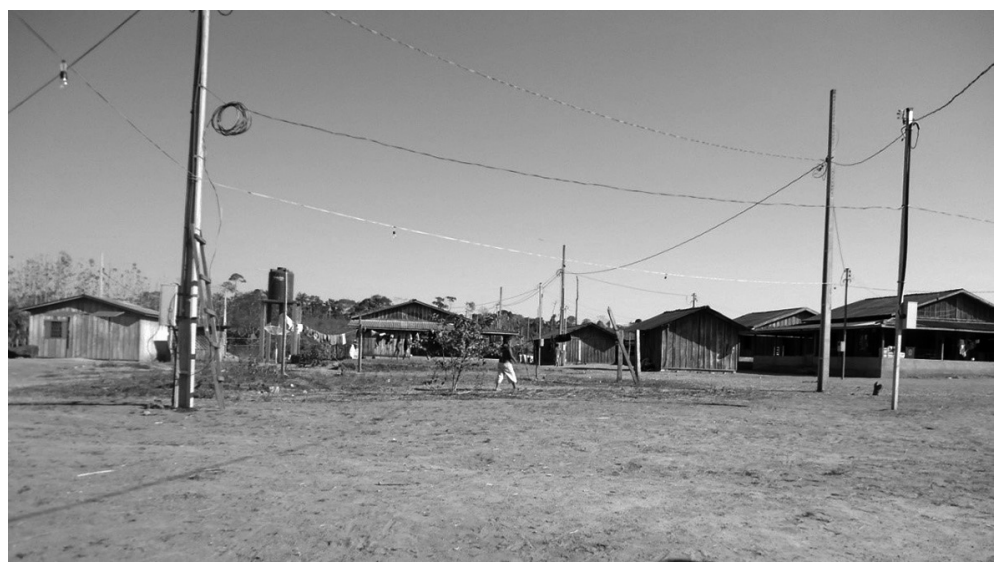

Foto 2 - Construções das casas nos moldes das cidades Fonte: Cláudia Nascimento Oliveira, 2011.

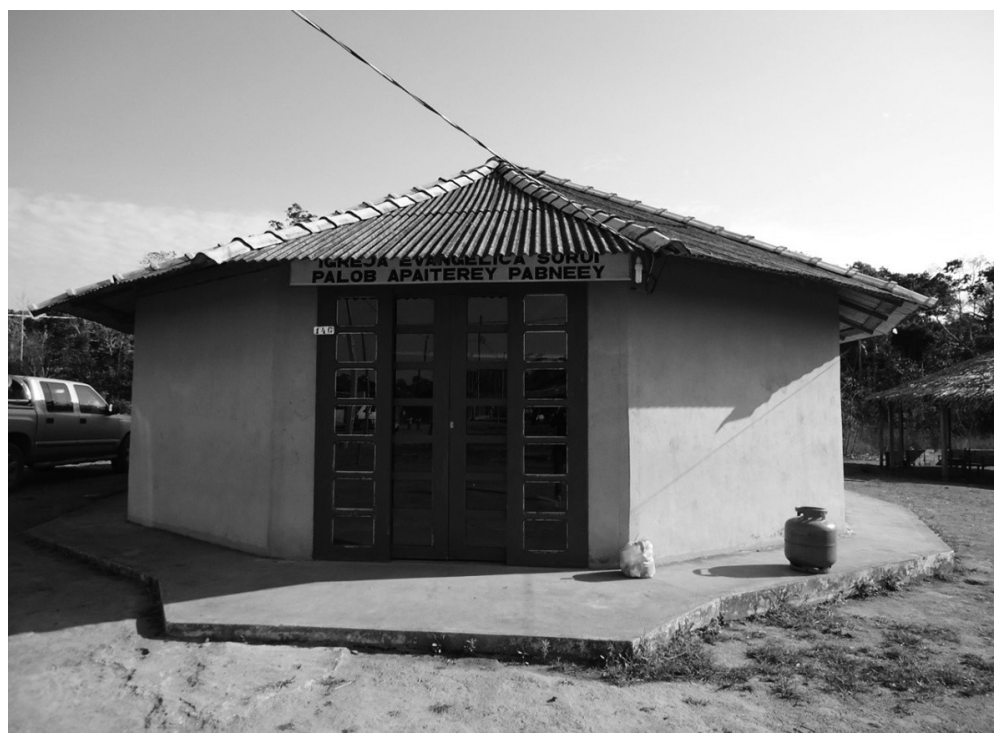

Foto 3 - Edificação da igreja evangélica

Fonte: Cláudia Nascimento Oliveira, 2011. 


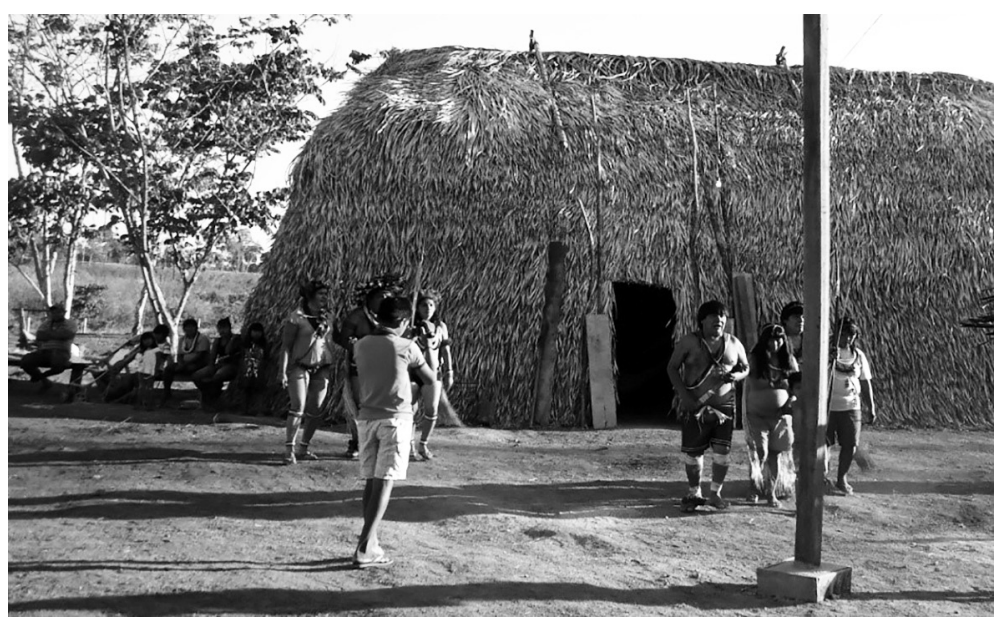

Foto 4 - A maloca que apenas servia como alojamento para os visitantes e não mais como moradia

Fonte: Cláudia Nascimento Oliveira, 2011.

A educação também passou por transformações. Com exceção dos mais idosos, os demais falam o português fluentemente, além de dominar sua língua mãe, o tupi-mondé. Adotavam o português para se comunicar conosco e o mondé para conversar entre si. Alguns jovens dominavam mais o português do que a língua materna, isso por conta de frequentarem escolas na cidade e consequentemente conviverem com os "não indígenas". Mesmo assim há a valorização de suas origens e de sua língua.

Os Paiter Suruí procuram resgatar e valorizar sua cultura, como instrumento de permanência e, consequentemente, reafirmar sua identidade. Uma das estratégias é o ritual do Mapimaí, transmitido pelos mais experientes e idosos à geração seguinte. Claval aborda essa questão da transmissão e difusão desses valores ao afirmar que:

A cultura é a soma dos comportamentos, dos saberes, das técnicas, dos conhecimentos e dos valores acumulados pelos indivíduos durante suas vidas e, em uma outra escala, pelo conjunto dos grupos de que fazem parte. A cultura é herança transmitida de uma geração 
a outra. Ela tem suas raízes num passado longínquo, que mergulha no território onde seus mortos são enterrados e onde seus deuses se manifestaram. Não é, portanto, um conjunto fechado e imutável de técnicas e de comportamentos. Os contatos entre outros povos de diferentes culturas são algumas vezes conflitantes, mas constituem uma fonte de enriquecimento mútuo. A cultura transforma-se, também sob o efeito das iniciativas ou das inovações que florescem no seu seio. (Claval, 2001, p.63)

Mesmo com as mudanças, muitas tradições ainda estão evidentes e presentes no cotidiano da aldeia. Os Paiter Suruí são compostos por quatro clãs: Kaban (mirindiba, uma fruta regional), Gameb (marimbondos pretos), Gabgir (marimbondos amarelos) e Makor (taboca, uma espécie de bambu amazônico).

Cada clã possui um líder que o representa nas reuniões para discutir os assuntos da etnia. Há a presença de um líder maior, denominado "Labiway eSaga". Almir Narayamoga Suruí foi eleito em 2010 para ser o líder geral do povo Paiter, ficando sob sua responsabilidade as principais decisões que dizem respeito à etnia. Ele foi eleito pelo conselho de clãs. É importante destacar que a escolha do Labiway eSaga é feita democraticamente e, de tempos em tempos, outro líder assume o lugar. O fluxograma a seguir demonstra como se dá a governança paiter.

A etnia Paiter exerce os seus valores culturais de forma muito particular, conforme observa Cardozo (2011, p.5):

Sua organização social preconiza a exogamia clânica, onde o casamento é permitido somente com os membros de outro clã. São poligâmicos, sendo que especialmente os chefes e as lideranças podem casar-se com mais de uma mulher. Mantêm como regra preferencial o casamento avuncular.

Durante a nossa permanência foi possível vivenciar o que Cardozo relatou. Os casamentos são arranjados pelo patriarca. Há casos em que a mulher já é prometida desde o nascimento. As mulheres 
Quadro 1 - Forma de governança paiter

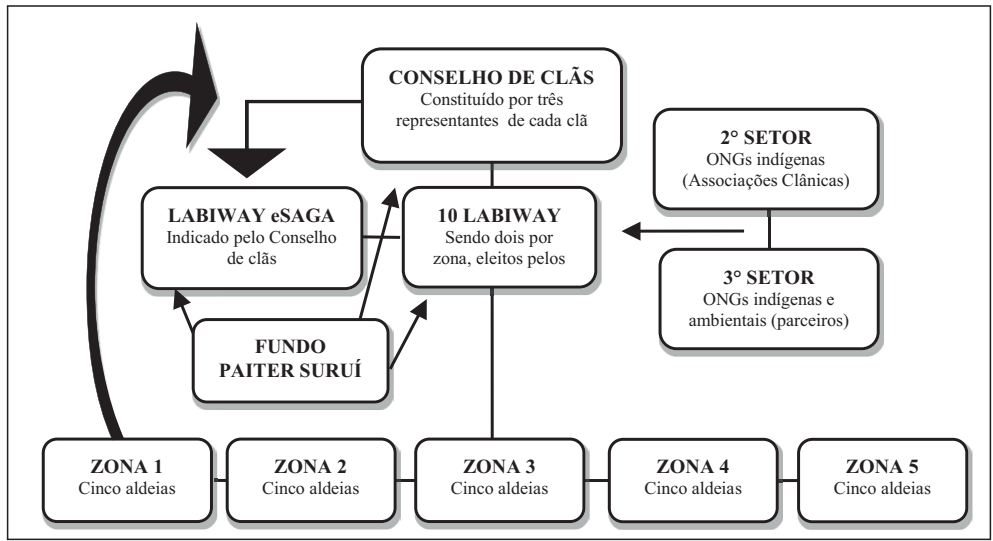

Fonte: Cardozo, 2011.

geralmente casam-se muito jovens. Observamos que somente o homem tem a liberdade de casar-se com uma mulher branca. Segundo os Paiter Suruí, a mulher ao casar-se com um indígena torna-se uma indígena e seus filhos serão considerados como tais.

No caso de uma indígena casar-se com um homem branco, seu marido não será considerado como membro, assim como seus filhos. Passam a ser tratados como "outros". Os casamentos acontecem entre os clãs, sendo permitido aos líderes casar com mais de uma mulher, desde que consigam sustentá-las. O líder maior é casado com duas não indígenas. Em entrevista com uma delas, a mesma informou que não seria um problema se o marido tiver uma terceira esposa.

Durante nossa estadia na aldeia, tantas outras observações foram feitas. No que diz respeito ao ritual do Mapimaí, foi celebrado em três dias e em cada dia havia uma atividade específica. Os clãs convidados Gameb, Gabgir e Makor confeccionavam presentes durante a celebração do Mapimaí, para oferecer ao seu anfitrião Kaban.

A participação no ritual não se restringia somente aos Paiter Suruí. Nosso grupo de alunos poderia, além de observar, participar do ritual. No entanto, em função do horário, não foi possível acompanhar o ritmo do coletivo no Mapimaí. Participávamos somente durante o dia, tamanha a sua intensidade. Para os Paiter Suruí, a base da vida é 
a floresta. Ela oferece recursos necessários à sobrevivência das populações indígenas. É o que determina a energia necessária para realizar o ritual. A energia física e psiquicamente gasta para a realização do ritual é intensa, sendo que a floresta impõe esse ritmo aos participantes. Os ritos iniciaram-se às 4 horas da manhã e prosseguiram até a meia-noite, com cantos e manifestações ininterruptas. $O$ primeiro dia foi dedicado à criação de canções e à pintura. $\mathrm{O}$ segundo foi dedicado ao ritual da chich $a^{3}$ e o terceiro destinado à caça.

A importância do ritual, assim como todo seu simbolismo decorrente, consiste na transmissão de valores dos mais idosos para os jovens com o objetivo de permanência cultural. Os indígenas mais velhos sabem que possivelmente outras manifestações e valores serão incorporados, pois seus filhos convivem com a sociedade envolvente diariamente; mesmo assim, acreditam que manterão suas origens. Paul Claval, mais uma vez, reforça o valor da transmissão de uma cultura quando diz:

A cultura só existe através dos indivíduos aos quais é transmitida, e que, por sua vez a utilizam, a enriquecem, a transformam, a difundem. Sem ela, eles estariam desamparados: o instinto não é suficiente para guiá-los. [...] A linguagem permite que os homens se comuniquem. Suas relações só se desenvolvem a contento quando inseridas em contextos admitidos por todos. (Claval, 2001, p.89)

Considerando o que Claval abordou quanto à transmissão de uma cultura, os Paiter Suruí procuram, através do Mapimaí, a

3 É o nome de uma bebida indígena fermentada feita de mandioca, milho, batata ou cará, guardada por vários dias em recipiente de barro, que, por sua vez, é coberto por palhas. Por conta da fermentação, a chicha se transforma em uma bebida de teor alcoólico e é extremamente forte. Ao ingeri-la em grande quantidade, a pessoa acaba vomitando. A concepção dos Paiter Suruís é que a chicha purifica o espírito. O desafio da festa é não ficar bêbado. O clã que oferece a chicha tenta alcoolizar os líderes dos demais clãs, que evitam demonstrar estarem alcoolizados, porque isso se constitui uma grande vergonha diante dos demais da etnia (Oliveira et al., 2011, p.5). Outras etnias possuem variadas designações para a bebida, tais como caissuma, caiçuma, caium, entre outras. 
permanência cultural que se encontrava adormecida por conta do constante contato com a cultura "não indígena".

As imagens a seguir retratam alguns momentos do Mapimaí. As fotos 5 e 6 referem-se ao momento em que a chicha era ingerida pelos participantes do ritual. A foto 7 refere-se ao momento da dança, no qual os convidados indígenas e não indígenas se confraternizam. É nessa ocasião que os cantos criados no dia anterior são entoados.

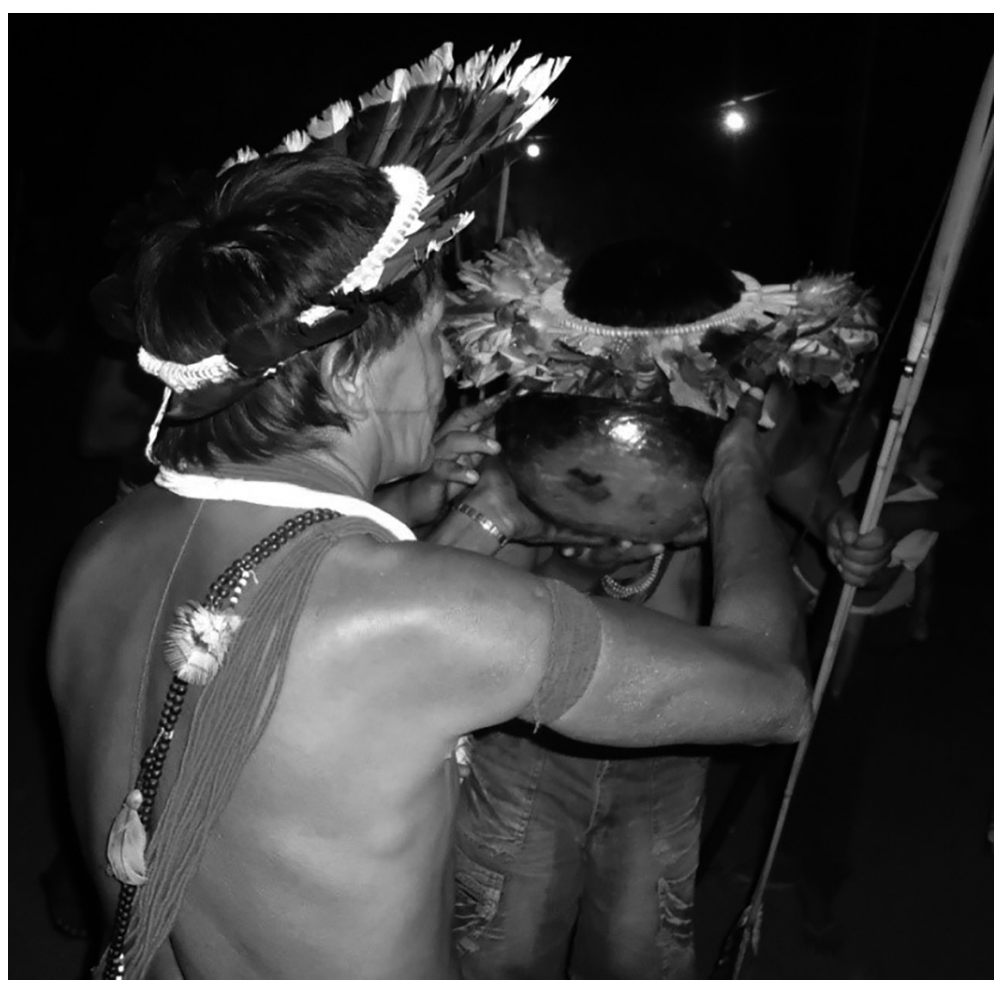

Foto 5 - Ritual da chicha no primeiro dia. A bebida é oferecida aos participantes Fonte: Cláudia Nascimento Oliveira, 2011. 


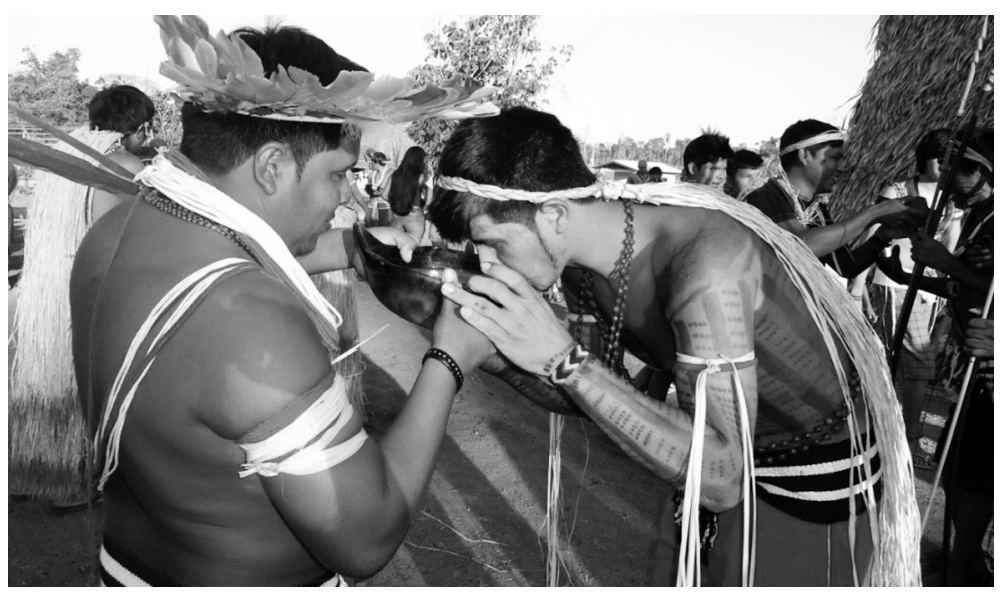

Foto 6 - Ritual da chicha no segundo dia, quando os clãs convidados devem beber toda a chicha como forma de agradecimento Fonte: Cláudia Nascimento Oliveira, 2011.

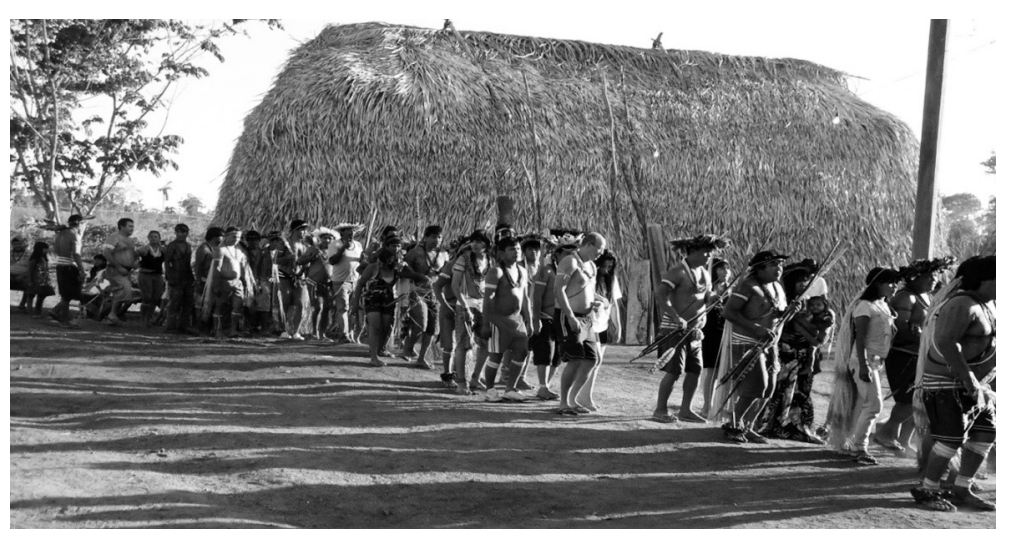

Foto 7 - A dança de confraternização dos clãs e convidados

Fonte: Cláudia Nascimento Oliveira, 2011.

As fotos 8 e 9 demonstram como a vestimenta da sociedade envolvente está inserida nos jovens, que cada vez mais aderem a valores não indígenas também na língua que falam ou no seu modo de agir. Ficou evidente em nossas observações a importância do resgate da cultura dos seus antepassados. 


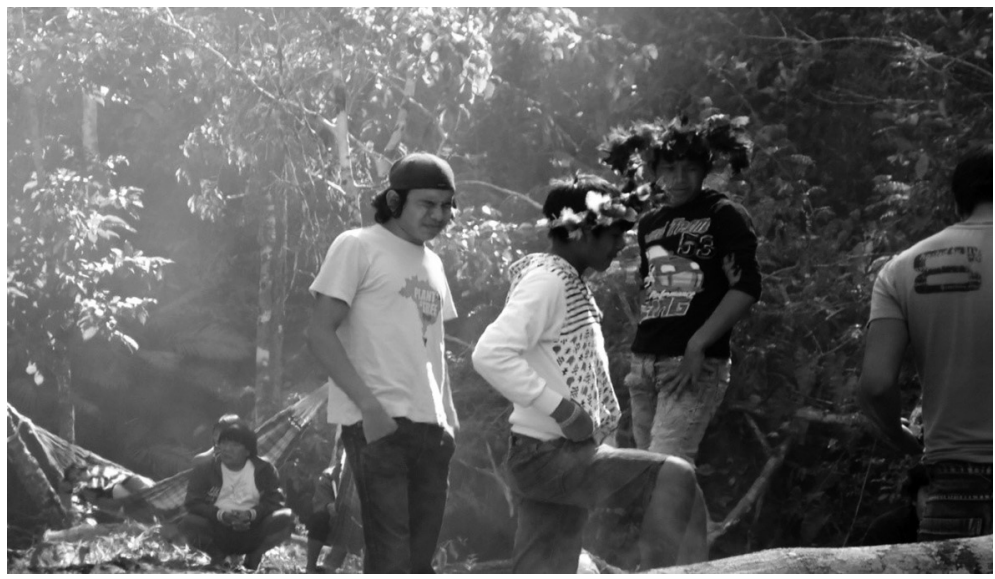

Foto 8 - Os jovens suruís observando os preparativos Fonte: Cláudia Nascimento Oliveira, 2011.

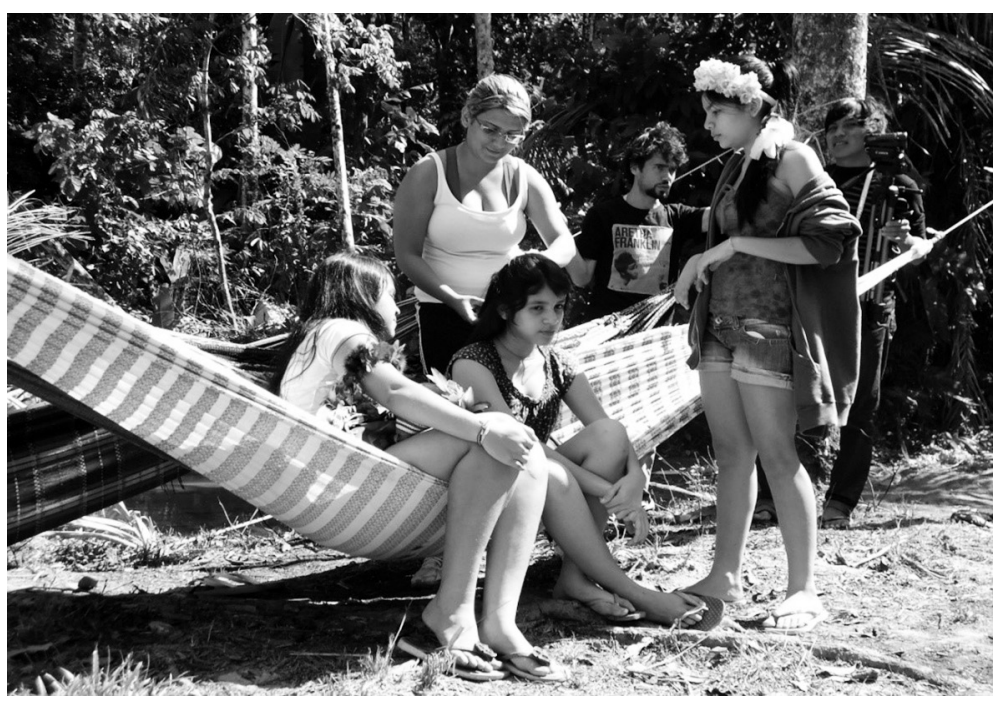

Foto 9 - As jovens suruís

Fonte: Cláudia Nascimento Oliveira, 2011.

Os Paiter Suruí, apesar do pouco tempo de contato com a sociedade envolvente, se distinguem de outras etnias, quando trata de exercitar as relações em busca de benefícios e melhorias para o seu 
povo. O Labiway eSaga, representando a Associação Metareilá do Povo Indígena Paiter Suruí, fechou parceria com o Google Earth para a elaboração do mapeamento e gestão de recursos florestais. Inúmeras visitas foram realizadas pelos técnicos do Google Earth após o acordo, sendo que os indígenas receberam treinamento para acessar a internet, postar vídeos, bem como monitorar possíveis agressões em seu território (invasões, roubo de madeira, entre outros) tendo como ferramenta o Google Earth.

Outra observação importante a ser citada é que os Paiter Suruí se destacam no cenário nacional e mundial com o Projeto de Carbono Floresta Suruí o REED+, que surgiu como uma alternativa de financiamento e geração de renda para o coletivo. O objetivo é trabalhar com a preservação da Amazônia, evitando que ela seja desmatada, e também no reflorestamento de áreas que tenham sido degradadas, com a finalidade de "sequestrar" o carbono, impedindo que ele seja liberado para a atmosfera.

\section{Considerações finais não conclusivas}

Mesmo com toda a violência (espoliação de terras, etnocídios, usurpação de direitos, entre outros), os indígenas continuam com uma luta incessante na busca de permanência cultural, do fortalecimento de suas raízes e da transmissão de conhecimentos para seus descendentes. Tal fato foi percebido e constatado com o trabalho de campo junto aos Paiter Suruí que, mesmo com o contato com a sociedade envolvente e as transformações ocorridas em virtude deste contato, mantêm uma preocupação na transmissão dos conhecimentos ancestrais para os mais jovens, de modo que a sua cultura continue a se perpetuar, evitando perda ou esquecimento com o transcorrer dos anos. O ritual do Mapimaí representou bem essa questão.

A maioria dos jovens nunca havia participado desse ritual, pois a última edição ocorrera em 2002. Dentre os mais idosos ou guardiões da memória ficou acordado que o Mapimaí seria realizado com maior frequência com o objetivo de não se perder os valores culturais. 
A partir da mudança na forma de relacionar-se com o mundo, como a parceria entre os indígenas e o Google Earth, ${ }^{4}$ os Paiter Suruí se tornaram conhecidos em todo o planeta, ganhando visibilidade inclusive para viabilizar projetos e parcerias. Nos dias atuais é possível rastrear qualquer ação ilegal dentro da Terra Indígena Paiterey Karah (Sete de Setembro); a informação é repassada imediatamente aos órgãos federais. Como essa prática confronta os interesses dos madeireiros que exploram ilegalmente a floresta, alguns dos líderes dos Paiter Suruí sofrem constantemente ameaças. Outro destaque foi o fato de terem se tornado a primeira etnia indígena do mundo a ter um projeto aprovado e certificado de carbono.

Algumas perguntas ficam no ar: como estariam esses indígenas se não tivessem tido o contato com a sociedade envolvente? Como esse contato é cada vez mais constante e intenso, essa etnia resistirá e continuará preservando sua cultura? Ou seus descendes se assemelharão ao modo de vida dos não indígenas?

Acreditamos que o contato era algo inevitável, a região amazônica seria povoada em algum momento, assim como ocorreu nas demais regiões. Mas outro questionamento que nos fazemos é: para povoar seria preciso dizimar os que aqui estavam? Provavelmente a busca pelo desenvolvimento explique tais ações, mas não acreditamos que tais desculpas sejam aceitáveis para aqueles que desejavam apenas continuar a viver do seu jeito em uma terra que consideram ser sua.

Ao final de nossa visita chegamos à conclusão que essa etnia procurou usufruir da melhor forma possível do contato com a sociedade envolvente. Foram dias especiais em que nos desprendemos um pouco da correria da cidade e vivenciamos o dia a dia de uma etnia que luta para que sua cultura não seja esquecida.

4 Através da parceria com o Google, por meio de um software gratuito disponibilizado pela empresa, hoje é possível acompanhar o desmatamento do estado de Rondônia. 


\section{Referências bibliográficas}

ALMEIDA SILVA, A. de. Territorialidades e identidade dos coletivos Kawahib da Terra Indígena Uru-Wau-Wau em Rondônia: "Orevaki Are" (reencontro) dos "marcadores territoriais". Tese de Doutorado em Geografia. Curitiba, SCT/RCT/DG/PPG/UFPR, 2010, 301p.

ALMEIDA SILVA, A. de; LEANDRO, E. L. Questão indígena na Amazônia, a especificidade de Rondônia: algumas considerações. In: AMARAL, J. J. de O.; LEANDRO, E. L. (org.). Amazônia e cenários indígenas. São Carlos: Pedro \& João Editores, 2010.

BORGES, M. C. Da observação participante à participação observante: uma experiência de pesquisa qualitativa. In: RAMIRES, J. C. de L.; PESSÔA, V. L. S. Geografia e pesquisa qualitativa nas trilhas da investigação. Uberlândia: Assis, 2009.

CARDOZO, I. B. (org.). Etnozoneamento Paiterey Karah: terra indígena Sete de Setembro. Porto Velho: Kanindé-Associação de Defesa Etnoambiental, 2011.

CLAVAL, P. A geografia cultural. 2.ed. Florianópolis: Edufsc, 2001.

GUZMÁN, D. de A. Índios misturados, caboclos e curibocas: análise de um processo de mestiçagem, Rio Negro (Brasil), séculos XVIII e XIX. In: ADAMS, C.; MURRIETA, R.; NEVES, W. Sociedades caboclas amazônicas: modernidade e invisibilidade. São Paulo: Annablume, 2006.

MINDLIN, B. Nós Paiter - os suruís de Rondônia. Rio de Janeiro: Vozes, 1985. Narradores Suruí. Vozes da origem - Os narradores Suruí. São Paulo: Ática/Iamá, 1996.

OLIVEIRA, C. N. et al. Raízes da cultura Paiter Suruí e o olhar sobre as relações de gênero na aldeia indígena Apoena Meireles em Rondolândia - MT. ANAIS do IV Colóquio do Núcleo de Estudos em Espaço e Representações-NEER: (As Múltiplas Espacialidades Culturais: Interfaces: Regionais, Urbanas e Rurais). Santa Maria: UFSM, 2011. v.1.

OLIVEIRA, G. M. Oficialização de línguas em nível municipal no Brasil: algumas considerações político-linguísticas e jurídicas preliminares. In: AMARAL, J. J. de O.; LEANDRO, E. L. (org.). Amazônia e cenários indígenas. São Carlos: Pedro \& João Editores, 2010.

OLIVEIRA, O. A. Geografia de Rondônia, espaço e produção. Porto Velho: Dinâmica, 2003.

ROCHA, G. Multiplicadores do conhecimento. Rede Povo da Floresta. Disponível em: <http://www.redepovosdafloresta.org.br/exibePagina.

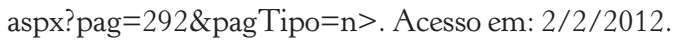


SCARAMUZZA, G. F. Lugar, educação e identidades em transformação na Amazônia. In: AMARAL, J. J. de O.; LEANDRO, E. L. (org.). Amazônia e cenários indígenas. São Carlos: Pedro \& João Editores, 2010.

TEIXEIRA, M. A. D; FONSECA, D. R. História regional: Rondônia. Porto Velho: Rondoniana, 1998.

TERRA INDÍGENA Sete de Setembro. Aquaverde. Disponível em: <http:// www.aquaverde.org/por/surui_terra.shtml $>$. Acesso em: 10/1/2012. 


\title{
REPRESENTAÇÃO CULTURAL PAITER SURUÍ: UM RITUAL DE CELEBRAÇÃO DA VIDA ${ }^{1}$
}

\author{
Ananda Catrice Lima da Cunha* \\ Luís Carlos Maretto** \\ Adnilson de Almeida Silva**
}

As etnias indígenas com seus modos de vida são detentoras de representações culturais que, em seu contexto de apreensão da realidade, apresentam relação direta com a respectiva visão e experiência de mundo. O presente ensaio relata e analisa as diversas formas de representações dos Paiter Suruí que, com seu ritual denominado Mapimaí ou "criação do mundo", demonstram sua identidade étnica ao mesmo tempo que buscam a permanência, ou seja, a manutenção de suas origens, ainda que estas, nos dias atuais, incorporem novas representações oriundas da forte influência da sociedade envolvente.

Compreender o ritual indígena tem o sentido de apreender sua identidade cultural, bem como os espaços e territorialidades que

1 Apoio MCT/CNPq, Projeto "Estudo das representações amazônicas: marcadores territoriais, culturais e socioambientais dos Paiter Surui” - Edital MCT/ CNPq 14/2010 - Universal.

* Geógrafa, mestre em Geografia pela Unir, pesquisadora do Grupo de Estudo e Pesquisa sobre Modos de Vida e Culturas Amazônicas - Gepcultura. E-mail: anandacunha@hotmail.com.

** Engenheiro florestal, mestre em Geografia pela Unir e pesquisador do Gepcultura.E-mail: 1cmaretto@gmail.com.

*** Mestre em Geografia pela Unir, doutor em Geografia pela Universidade Federal do Paraná (UFPR), pesquisador do Gepcultura e docente do Departamento de Geografia e do PPGG/Unir. E-mail: adnilsonn@gmail.com. 
constroem a partir das vivências e experiências cosmogônicas, cujo universo é constituído de representações, significados e símbolos que deram o sentido a suas existências. Assim, em nossa análise percebemos alguns dos fenômenos que compõem a cultura dos Paiter Suruí e que são importantes para a organização de sua coletividade, como também para a ciência, com o sentido de entendimento do rico conhecimento que podem propiciar inclusive para a sociedade envolvente.

\section{Considerações iniciais}

A diversidade amazônica atrai nossa atenção para investigar espaços ainda desconhecidos, essa vasta variedade de espaços culturais desperta nos pesquisadores o desejo de desvendar esse universo rico em representações, signos e significados. A compreensão da cultura amazônica nesse espaço de representações exige investigações que considerem o universo cultural na perspectiva das relações sociais estabelecidas pelos mais distintos povos que compõem suas espacialidades e territorialidades.

Nesse cenário cultural, percebemos que todos os seres humanos trabalham de forma a construir espaços e definir territórios, mantendo relações contínuas que qualificam o espaço e dão significados representativos a suas existências. Essa construção é percebida a partir das ferramentas utilizadas para analisar as relações sociais estabelecidas pelo homem com o espaço, entre elas a percepção e a pesquisa das representações sociais. Com o estudo dessas concepções identificamos a construção dos signos sociais presentes na cultura, logo, trata-se de relações socioculturais.

Para compreender melhor essa construção de representações, signos e símbolos nos espaços socioculturais, realizamos trabalho de campo na autodenominada Terra Indígena Paiterey Karah ou Sete de Setembro, na concepção da sociedade envolvente, onde habita a etnia Paiter Suruí. O trabalho especificamente ocorreu, a convite da etnia, na aldeia Apoena Meireles, localizada em Rondolândia 
(MT). Nosso objetivo foi o de compreender algumas representações culturais, sendo uma delas o ritual do Mapimaí.

Em sua língua materna, paiter suruí quer dizer "gente mesmo, gente de verdade", o que se caracteriza e afirma como pertencimento ou identidade étnica. A população da terra indígena é de aproximadamente 1.350 pessoas, que vivem em 25 aldeias; a língua falada é o tupi mondé e o segundo idioma é o português, inserido no pós-contato. Essa etnia indígena é detentora de várias manifestações que fazem parte de sua cultura, entre elas o ritual do Mapimaí, uma afirmação identitária cujo estabelecimento consiste na busca do equilíbrio entre a etnia, a cultura e a natureza.

Sob essas premissas realizou-se uma pesquisa com o objetivo de conhecer, ainda que parcialmente, essa cultura amazônica em suas formas de representações presentes no ritual e a percepção da relação social existente entre indígenas e a sociedade envolvente.

\section{As representações como meio de interação}

Com essa perspectiva foi realizada uma pesquisa empírica sobre a manifestação cultural indígena, tendo como procedimento metodológico a pesquisa qualitativa, que de acordo com Siena (2007) tem um processo de reflexão e análise da realidade através da utilização de métodos e técnicas para a compreensão detalhada do objeto de estudo em seu contexto histórico e segundo sua estruturação.

A escolha desse procedimento metodológico ocorreu devido à necessidade de compreender as representações dessa etnia no espaço amazônico, observando a importância da diversidade sociocultural da região. De acordo com Kozel e Souza (2009, p.123):

As representações espaciais advêm de um vivido que se internaliza nos indivíduos, em seu mundo, influenciando seu modo de agir, sua linguagem, tanto no aspecto racional como no imaginário, seguidas por discursos que incorporam ao longo da vida. 
Dessa maneira, o trabalho se pautou na abordagem de estudos da percepção com base humanística, o que proporcionou uma reflexão sobre a espacialidade e suas diversas formas de representação. Para a compreensão dessa abordagem foram utilizados os enunciados teóricos recomendamos por Borges (2009, p.190-1):

"ver", "sentir", "analisar" o lugar aonde se chega, seja uma cidade, uma comunidade, uma tribo indígena, ou até mesmo a casa de alguém [...] É preciso que o pesquisador se identifique com esse lugar [...] Identificar-se com o lugar, gostar de estar lá, é um passo pertinente e, muitas vezes, imprescindível. Desta forma, "estar aberto" pode ser entendido como estar disposto a gostar, a se identificar, a escolher os lugares por onde anda e, sobretudo, as pessoas deste lugar.

A pesquisa foi desenvolvida, assim, de forma a sentir a construção desses espaços de relações culturais, percebendo que tudo vai adquirindo significados, os sons, as danças, as músicas, as múltiplas interações sociais que ocorrem com a chegada dos visitantes e que gera intercâmbio e apreensão de culturas.

\section{Construindo a base teórica da pesquisa}

Para a compreensão da pesquisa, utilizamos teóricos e conceitos que nos auxiliarão no entendimento da perspectiva cultural na Amazônia. Entre esses autores citamos Claval (2001, p.63), que discorre sobre a importância do fenômeno cultural:

A cultura é a soma dos comportamentos, dos saberes, das técnicas, dos conhecimentos e dos valores acumulados pelos indivíduos durante suas vidas e, em outra escala, pelo conjunto dos grupos de que fazem parte. A cultura é herança transmitida de uma geração a outra. 
Nesse contexto inicia-se o processo de entendimento dessa manifestação cultural, ao observar que ao longo do tempo as mais distintas comunidades formam suas culturas, acumulam valores e transmitem a herança cultural de geração em geração.

A compreensão é que esse processo é lento e gradativo - porém, dotado de uma dinâmica própria, em que no caso deste estudo, os Paiter Suruí possuem uma cultura herdada cosmogonicamente de seus antepassados, transmitida aos mais jovens por meio de ensinamentos que perpassam o ato de vestir, dançar, pintar e alcançam a espiritualidade e outros valores de subjetividade.

Com esse conceito observa-se que os espaços são construídos e qualificados, conforme observa Cassirer (2005): "devemos analisar as formas da 'cultura' humana para podermos descobrir o verdadeiro caráter do espaço e do tempo no nosso mundo humano". Essa questão consiste na análise das formas culturais que compõem o universo indígena em sua representação e vivência de mundo.

As imagens a seguir reportam a preparação do ritual Mapimaí, em que é possível entender as relações de construção do espaço indígena. As representações, os símbolos, os signos e os significados compõem o universo que é pleno de cosmogonia, isto é, dos fenômenos, entre eles, a espiritualidade. Neste caso, a espiritualidade é compreendida como a condição sine qua non do construto humano do espaço e da própria construção de mundo, cujo contexto é o próprio espaço de ação que está impregnado das experiências e vivências dos Paiter Suruí.

A prática ritual é realizada com alegria, porque é um reencontro de celebração da vida, é o momento oportuno de renovar as relações de parentesco, de refletir sobre o espaço e as experiências adquiridas dos antepassados. Em síntese, o ritual é representativo no sentido de temporalidades distantes (passado, presente e futuro), imbricadas na territorialidade que é compreendida na junção dos fenômenos espirituais e materiais, o que significa comunhão e reflexão de suas trajetórias.

O Mapimaí é o momento oportuno da "fabricação de corpos", quando as pinturas e os adereços vestem o físico e transcendem espiritualmente em sua relação com Palop, o demiurgo criador de tudo o 


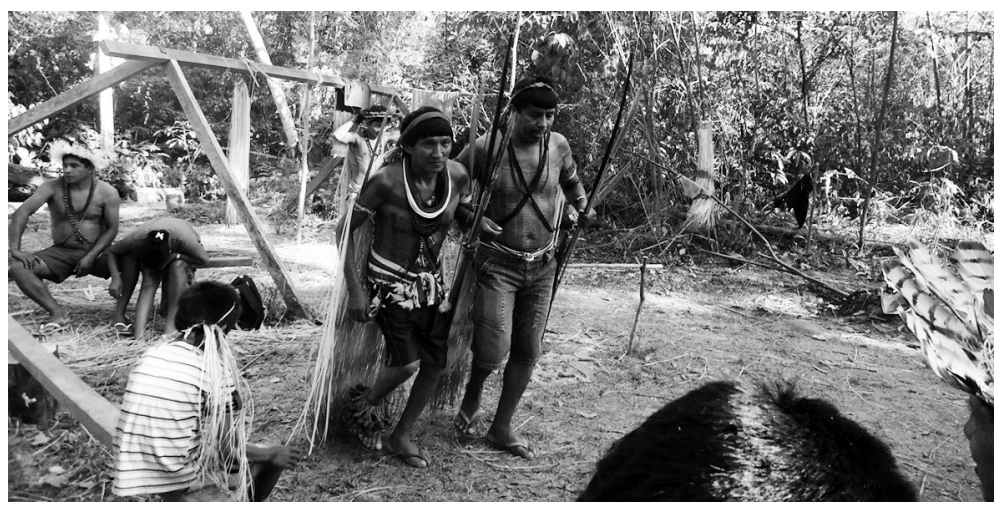

Foto 1 - Preparação para o ritual indígena: os mais velhos ensinam aos mais jovens

Fonte: Ananda C. Lima da Cunha, 2011.

que existe em seu universo representativo e que oferece a garantia de caminhar adiante, vencendo as agruras da vida, como energia renovadora. É o fazer "gente mesmo, gente de verdade".

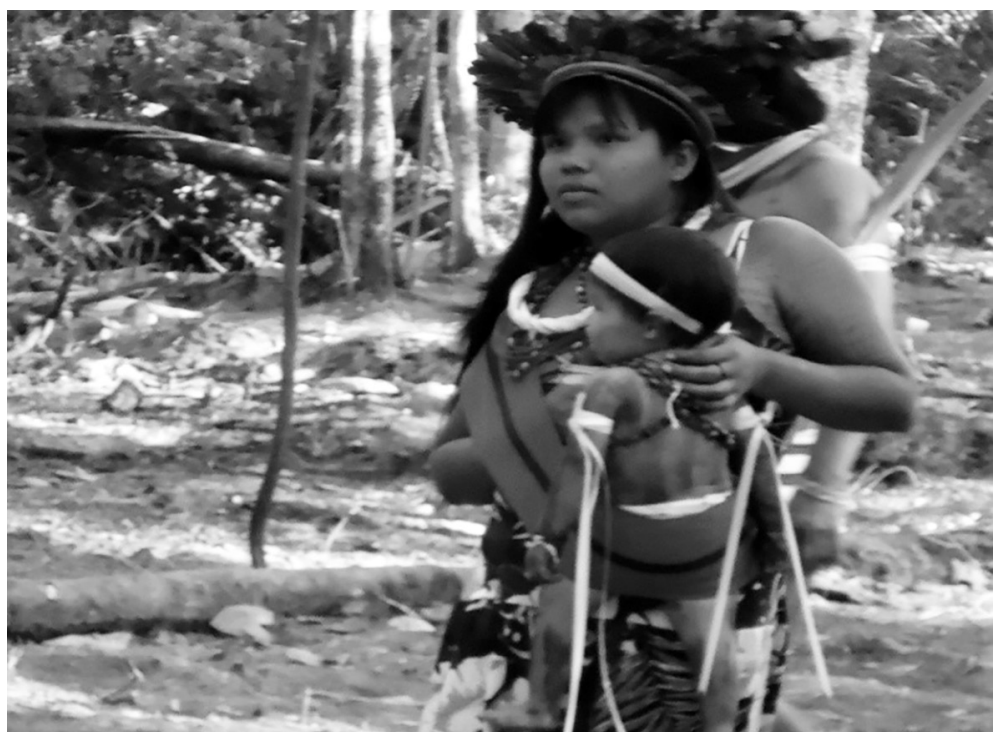

Foto 2 - Preparação para o Mapimaí e a "fabricação de corpos"

Fonte: Ananda C. Lima da Cunha, 2011. 
Nesse processo, as manifestações socioculturais presentificadas de representações no ritual constituem-se como fenômeno de atributo de identidade étnico e, nessa formação identitária, os lugares ganham morfologia qualificada. Em tal sentido, afirma Claval (2001, p.55):

os lugares não têm somente uma forma e uma cor, uma racionalidade funcional e econômica. Estão carregados de sentido para aqueles que os habitam ou que os frequentam. As pesquisas sobre percepção do espaço e do ambiente desenvolvidas pelos psicólogos são proveitosas. O romance torna-se algumas vezes um documento: a intuição sutil dos romancistas nos ajuda a perceber a região pelos olhos de seus personagens e através de suas emoções.

Através dessa conexão de conceitos abordados, nota-se que os lugares são formados pelo sentido e valoração que lhe é dado, pela emoção que carrega. Os Paiter Suruí dão forma ao espaço através da sua cultura, que luta em permanecer, mesmo com todos os avanços tecnológicos que a sociedade envolvente proporciona no sentido de anular ou invisibilizar as representações indígenas.

A ação representativa do ritual em se alinhar em fila indiana (foto 3 ) rememora o passado guerreiro e consiste numa marca valiosa de espacialidade e territorialidade, na qual é possível a leitura de afirmação de identidade étnica com o significado de que "isso nos pertence, porque é uma conquista realizada com a ajuda de nosso deus Palop".

A partir dessa reflexão, tem-se uma percepção sensível das representações espaciais provenientes das vivências, da força do imaginário indígena e dos significados atribuídos a cada manifestação cultural, conforme afirma Kozel e Souza (2009, p.123): “concebemos a representação como uma forma de linguagem impregnada de significados, de imagens, de valores sociais, refletindo a realidade ou vivência dos indivíduos".

Logo, o conceito de percepção procura esclarecer sobre os valores cognitivos, afetivos e simbólicos com a ligação ao lugar em que vivem e oferecem o sentimento de pertencimento e identidade, o que de acordo com Kozel e Souza (ibid., p.123): 


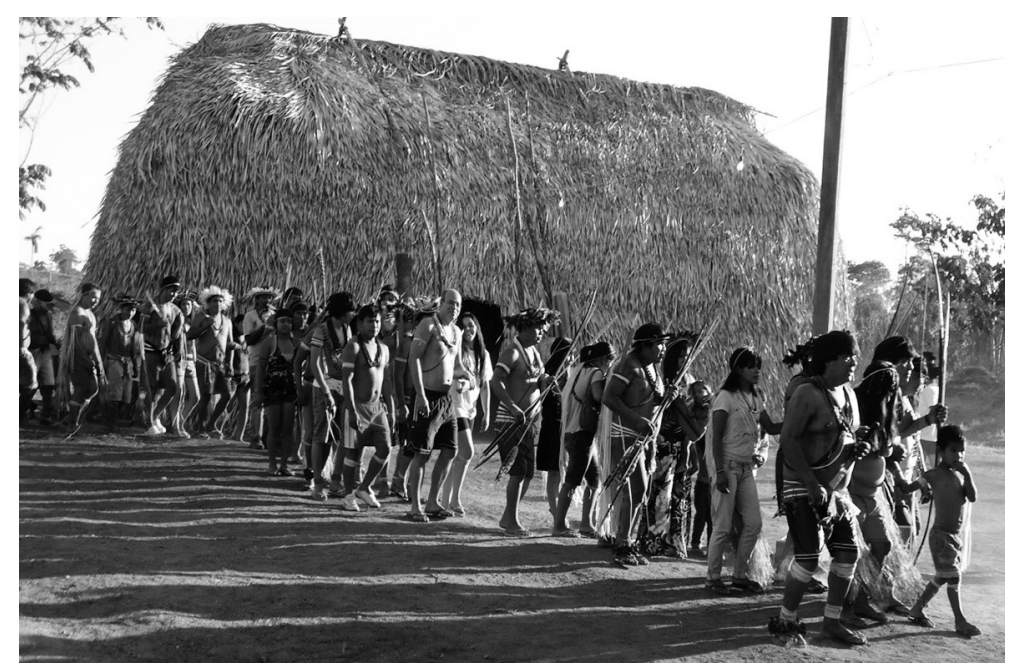

Foto 3 - Ritual indígena: os espaços passam a se formar Fonte: Cláudia Nascimento Oliveira, 2011.

A percepção envolve as trajetórias da vida social dos sujeitos, isto é, os significados, as diferentes experiências, os valores que os seres humanos atribuem à sociedade e aos homens. Na realidade, as pessoas atribuem significados particulares ao espaço e aos objetos que o compõem. É assim que percorremos esse mundo vivido, mostrando o quanto a linguagem é central na constituição do sujeito histórico e social.

Como se pode constatar, a representação está ligada à percepção como fenômeno de compreensão das ligações sociais que o ser humano estabelece no contexto social, de modo que se constitui como importante ferramenta de compreensão das etnias indígenas.

\section{Da percepção à representação espacial}

Compreender as representações presentes no contexto cultural não é uma tarefa fácil, pois como observamos trata-se de um processo 
contínuo de formação social de cada agrupamento e que envolve infindos signos, símbolos e significados, cujas apreensões encontram-se na subjetividade humana, ou seja, os valores intrínsecos são constituídos em forma de linguagens que não são perfeitamente codificáveis por aqueles que estão à margem de seus modos de vida.

A análise dessa formação perpassa contextos históricos, posto que não se trata somente de aspectos e elementos físicos, embora esses contextos possibilitem diagnosticar os processos de construção desse espaço. No senso comum da sociedade envolvente, não tem sentido entender, por exemplo, como o espírito do gavião, do macaco ou de outro animal poderia ser um dos responsáveis pela criação do mundo.

Tal fenômeno não é cognoscível se não se compreender os códigos, os signos, as representações, os símbolos e os significados que estão vivos no construto mental de um povo, assim como também é incompreensível a deidade ou a divindade para os indígenas de algo que não pertence a seu meio e modo de vida.

Nosso trabalho de campo na aldeia Apoena Meireles dos Paiter Suruí nos mostrou um pouco desse processo de relação de construção de espaços e visão de mundo, que na esmagadora maioria das vezes se realiza com estranhamento. Desse modo, percebemos que a presença das externalidades se realizava em toda parte, sejam com pesquisadores, jornalistas, fotógrafos, entre outros, que se encontravam para presenciar e participar do ritual.

Aqui ocorre uma simbiose, ou seja, à medida que influenciamos, somos igualmente influenciados, isto porque existe ainda que sutilmente uma troca cultural entre indígenas e sociedade envolvente. $\mathrm{O}$ participar do ritual dos Paiter Suruí, de certa forma, nos "transformava" em um deles e em contrapartida o uso da tecnologia (foto 4) era absorvido no "comportamento" da etnia.

É esse o caminhar contínuo entre culturas distintas que é, ao mesmo tempo, de aproximação e retração, em que ambas procuram compreender os códigos da outra, ainda que não seja plenamente acessível em sua totalidade, com ritmos, temporalidades e espacialidades diferentes. 


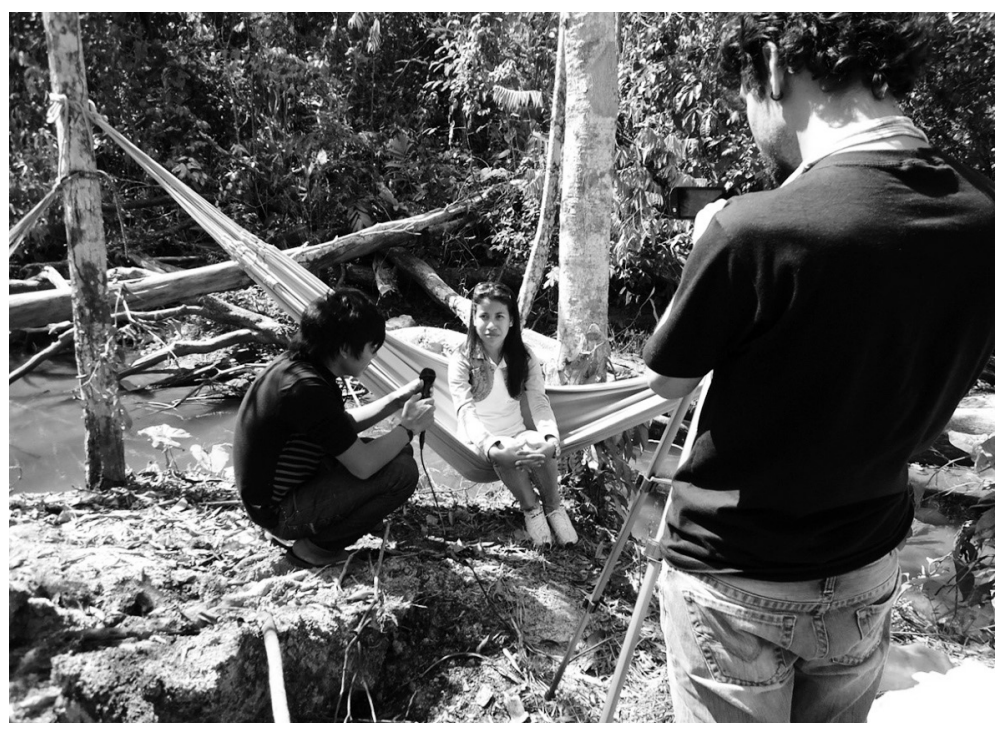

Foto 4 - Entrevista realizada por jornalistas

Fonte: Ananda C. Lima da Cunha, 2011.

Em um segundo momento, realizou-se uma análise geral da paisagem, notando que existem dois perfis de estrutura (fotos 5 e 6). De um lado, as casas típicas de alvenaria - "herança" da colonização da sociedade envolvente -; e do outro, as malocas dotadas de sentidos, significados e representações dos valores culturais indígenas, logo, espiritualizadas e construídas com elementos da natureza.

Dois perfis completamente antagônicos em um mesmo espaço de vivência. Quais as causas desse processo? Como compreender essa relação antagônica com configurações de poder existentes em um agrupamento humano como aquele?

A resposta ainda que seja não conclusiva está centrada na apreensão de novas representações que oferecem sentido de novas percepções de mundo ou de realidade por meio dos processos pelos quais os Paiter Suruí encontram-se inseridos na sociedade envolvente nacional e internacional. A aldeia agora possui um caráter que perpassa o território do Estado, é mediada pela globalização, de modo que a terra indígena é monitorada por satélites e computadores, tecnologias 
estas que parcelas dos indígenas dominam. A realização do Mapimaí agora não está restrita ao âmbito das aldeias, suas imagens percorrem o mundo instantaneamente por meio da internet e de outras mídias.

Esse caráter dado pelos meios de comunicação, ao contrário do que se pensa, tem-se constituído como importante não somente por demonstrar a cultura dos Paiter Suruí, mas como possibilidade de denunciar agressões sofridas pela etnia, seja em seus aspectos socioculturais, como também em termos ambientais, e são uma ferramenta para "garantir" a sobrevivência física dos habitantes da Terra Indígena Paiterey Karah.

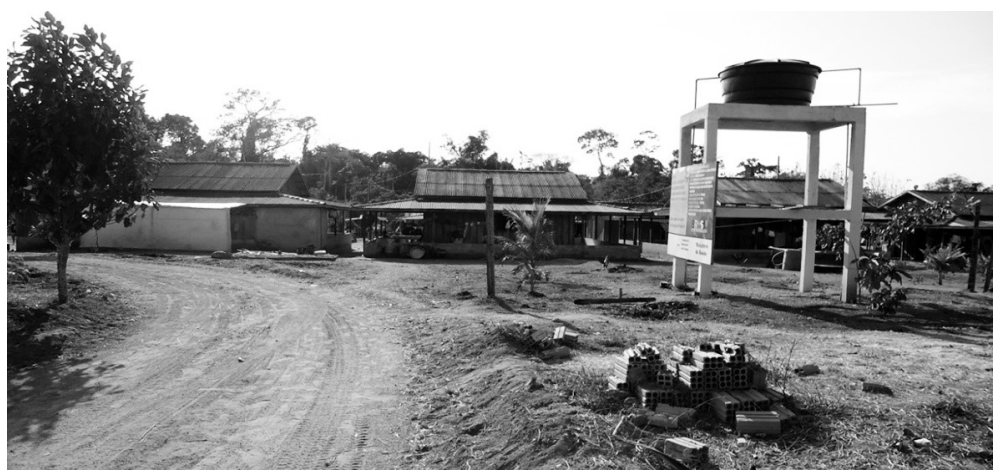

Foto 5 - Casas em alvenaria, a presentificação da atualidade Fonte: Ananda C. Lima da Cunha, 2011.

Os questionamentos feitos conduziram-nos à reflexão sobre um contexto histórico que ainda se encontra em processo de construção. De acordo com o Etnozoneamento Paiterey Karah, os Paiter Suruí passaram a ter contato com a sociedade envolvente a partir do ano de 1969, e o resultado desse contato com a população indígena foi a imediata redução de 5 mil para 250 pessoas. Significou praticamente a extinção da etnia, que teve grande parte do seu modo de vida modificada, com a inserção de valores que não possuíam em sua cultura.

Apesar de todos os percalços em sua trajetória pós-contato, a etnia tem lutado bravamente pela permanência de sua cultura e, com consciência, busca estratégias de compreensão sobre a sociedade 
envolvente como forma de garantia de sua sobrevivência. Visualizam, por exemplo, que a educação é um caminho possível de entender os variados códigos, signos e significados que são colocados como realidade objetiva.

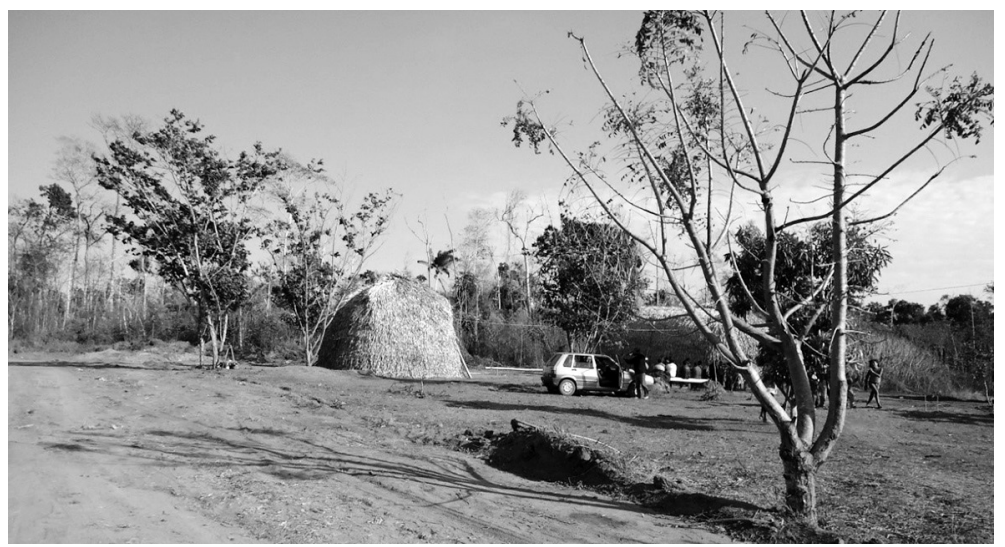

Foto 6 - Maloca, a presentificação da cultura e das heranças cosmogônicas Fonte: Ananda C. Lima da Cunha, 2011.

Nesse caminhar, a percepção sobre o ritual do Mapimaí é um reencontro cultural, dos Paiter Suruí com seus valores mais sublimes, no qual a criação do mundo é a possibilidade da permanência ainda que ressignificada em decorrência da realidade imposta. $\mathrm{O}$ ritual se insere como uma constante busca do equilíbrio entre o homem, a cultura, a espiritualidade e o meio ambiente, como condição de absorção de energia impulsora dos desafios do cotidiano.

Assim, em nossa percepção, a representação dos sentidos para os Paiter Suruí consiste na organização de quatro clãs: Gameb, Gabgir, Makor e Kaban. Estes estabelecem espacialidades específicas ou "marcadores territoriais", onde cada um possui seu papel no ritual e com códigos entendidos pela etnia e respeitados pela espacialidade do outro, de modo a qualificá-los.

Embora em determinado momento os clãs sejam detentores de espacialidades e identidades próprias, com o desenvolvimento do ritual ocorre uma junção e, com isso, manifesta a identidade dos Paiter 
Suruí, ou seja, juntos somos a mesma etnia, temos força e podemos vencer as dificuldades e desafios que nos são impostos.

Os "marcadores territoriais" são perceptíveis nos clãs, notadamente pelas expressões ou pinturas corporais com traços estéticos que distinguem suas ancestralidades, porém todos são pintados com penas de gavião - o espírito altivo e guerreiro. Na indumentária paiter suruí e que marca territorialidades/espacialidades, os cocares significam poder e respeito, sendo usados pelos idosos, pelos guerreiros - lideranças da etnia - que atuam como conselheiros responsáveis pela condução étnica e referenciais de etnoconhecimento para os mais jovens.

Em nossa percepção, o ponto máximo do ritual ocorre com o processo de renovação espiritual, quando os clãs se juntam para preparar a comida e a bebida servidas a todos. A refeição é composta de peixes e animais silvestres, especialmente macacos, que na cosmogonia paiter suruí são plenos de espiritualidade. Algumas espécies não são degustadas em razão dos valores herdados dos antepassados, e sua violação implica sortilégios para a etnia.

A bebida utilizada (foto 7) no ritual Mapimaí é conhecida como chicha, um fermentado que pode ser de milho, cará, mandioca ou outro tubérculo, e assim como a comida possui um significado espiritual de purificação. Seu consumo no ritual, em nossa ótica, constitui-se num desafio entre os clãs, em que se prova a resistência e a capacidade da liderança. O ritual, além do caráter espiritual, também pode ser entendido como a formação de alianças, reencontros, colaboração em forma de mutirão e reciprocidade simbólica, isto é, existe o momento que podemos entender como festa, mas ocorre a reflexão sobre as ações ocorridas no espaço.

Deste modo, a organização do ritual é responsabilidade de um clã anfitrião que oportuniza a oferta de alimentos e bebidas, enquanto os demais realizam a representação do que qualificam como criação do mundo. Em determinado momento os clãs convidados oferecem os presentes ao anfitrião e depois ocorre a partição ou troca simbólica dos presentes, o que poderíamos qualificar na sociedade envolvente como a confraternização entre parentes. 
Os presentes - colares, cocares, entre outros - significam o respeito pelo outro clã, seu caráter tem o sentido de fortalecer os laços de parentescos e construção de estratégias para a defesa do território. Possui ainda o sentido do desenvolvimento de habilidades, de aproximações, de entender a subjetividade do outro, o que significa as afinidades, o aprendizado e o respeito por tudo aquilo que, embora possa parecer uma construção individual, é perceptível tratar-se de algo coletivo, identitário e de pertencimento, cujas apreensões perpassam os aspectos puramente materiais.

Outro aspecto que merece atenção nessa construção ritualística éa ocorrência de casamentos cruzados ou exogâmicos ${ }^{2}$ - hoje em menor quantidade, devido às aquisições de novas representações e significados adquiridos do pós-contato.

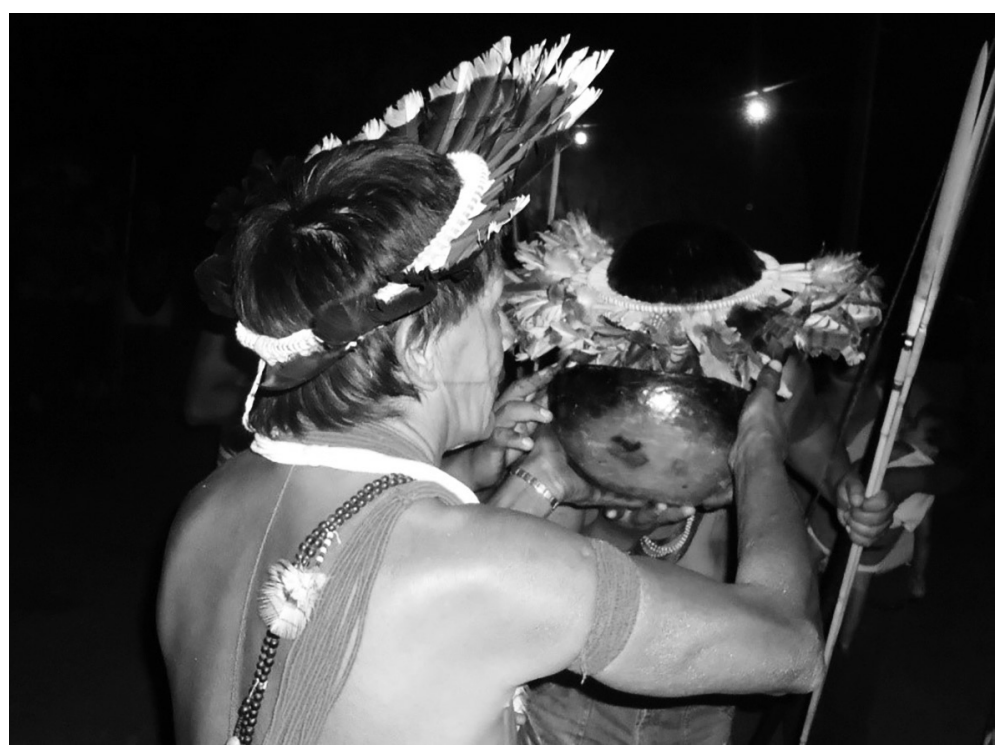

Foto 7 - Ritual indígena: degustação da chicha ou purificação do espírito Fonte: Cláudia Nascimento Oliveira, 2011.

2 Esse tipo de casamento ocorre entre clãs diferentes. Se ocorresse dentro do mesmo clã implicaria incesto, portanto, não é aceito entre os Paiter Suruí, porque isso se caracterizará como uma violência de seus códigos cosmogônicos. 
Diante dessa representação, nota-se que a cultura paiter suruí tem como objetivo a permanência de suas origens - ainda que com elementos de ressignificação -, de forma a incutir aos mais jovens a necessidade de sobreviverem cultural e espiritualmente, isto porque o enfraquecimento de seus valores implicará a fragilidade da etnia. Assim, salvaguardar os valores ancestrais não significa não aceitar as novas representações, ao contrário, sua incorporação com consciência refletirá no preparo de novos desafios.

Nesse novo caminhar, os Paiter Suruí possuem a convicção que existe uma necessidade proeminente de preparar suas lideranças, ouvir os ensinamentos dos idosos e respeitar continuamente a natureza, sem perder a clareza de serem indígenas, brasileiros, habitantes do mundo e que o mundo e suas representações devem ser colocados como pontos de reflexão da atual e das futuras gerações.

\section{Considerações finais não conclusivas}

De acordo o exposto, notamos a forte preocupação dos Paiter Suruí na manutenção de suas raízes e valores culturais que são transmitidos entre sucessivas gerações. Esse laço afetivo da manifestação cultural marca o território, define as espacialidades como construto de seu processo histórico, obtido com as vivências e experiências espaciais, consubstanciada como modo de vida pleno de qualidades.

No entanto, percebe-se que no contexto da paisagem ocorrem mudanças aceleradas, impulsionadas pelas influências externas, com a substituição de elementos que se encontram presentes no período anterior ao contato. Essas alterações consistem na estética da arquitetura, ou seja, com construção de residências em alvenaria dotadas de banheiros internos, energia elétrica e de utensílios como fogão a gás, geladeira, liquidificador, entre outros, o que dá ênfase ao novo perfil indígena.

Essas novas representações não anulam a identidade indígena, até porque incidem no bem-estar das famílias, as quais foram apresentadas ao "admirável mundo novo" que transporta consigo a 
modernidade presente no sistema econômico. Na realidade, os Paiter Suruí procuram nessas representações compreender o significado da sociedade envolvente e, com isso, intercambiar seus conhecimentos e usufruir de oportunidades possíveis que viabilizem a etnia no contexto da atualidade.

Um dos meios de adquirir conhecimento externo é o estabelecimento de parcerias com entidades governamentais e não governamentais, além de universidades, onde seus filhos buscam se capacitar técnica e academicamente para compreender os signos e significados que posteriormente são disseminados entre a população.

Por outro lado, percebe-se a presença de igrejas evangélicas no interior da terra indígena, que de forma direta e indireta influencia no modo de vida e na cultura dos Paiter Suruí, constatando-se ainda a atuação de madeireiros, garimpeiros e invasores que a todo custo tentam inviabilizá-los social, cultural e espiritualmente.

Apesar da pressão existente, essa etnia luta pela permanência de sua cultura, com a consciência da dificuldade inerente, considerando que sobretudo os mais jovens são atraídos com maior desenvoltura para compreender os signos, símbolos, representações e significados da sociedade envolvente.

A resistência é mais destacada entre os mais idosos, cuja compreensão reside na ideia de que perder sua cultura implicaria não somente a morte física, mas também espiritual. Nota-se, porém, que vários jovens conseguem entender os códigos e ensinamentos de seus antepassados e constroem um discurso apontando sua preocupação quanto ao futuro, como afirma Miguel Suruí, em Pamine: o renascer da floresta: "Gostaria que a gente permanecesse o que a gente é! Manter a nossa cultura e não perder nossa identidade. A nossa maior preocupação é com o nosso território, poder continuar com ele, ter árvore em pé, com a floresta viva" (Suruí, 2011, p.62).

Deste modo, as diversas formas de representações presentes no universo Paiter Suruí demonstram que seus valores culturais e modo de vida não estão dissociados da territorialidade/espacialidade conquistada e construída com muito empenho. $\mathrm{O}$ ato da etnia de convidar a universidade e várias pessoas da sociedade envolvente 
para participar do Mapimaí consiste numa estratégia de obter aliados para sua causa, ou seja, o "fortalecimento" cultural e a manutenção territorial.

\section{Referências bibliográficas}

ALMEIDA SILVA, A. de. Territorialidades e identidade dos coletivos Kawahib da Terra Indígena Uru-Wau-Wau em Rondônia: "Orevaki Are" (reencontro) dos "marcadores territoriais". (Tese de Doutorado em Geografia). Curitiba: SCT/RCT/DG/PPG/UFPR, 2010, 301 p.

LEANDRO, E. L. Questão indígena na Amazônia, a especificidade de Rondônia: algumas considerações. In: AMARAL, J. J. de O.; LEANDRO, E. L. (orgs.). Amazônia e cenários indígenas. São Carlos: Pedro \& João Editores, 2010.

BORGES, M. C. Da observação participante à participação observante: uma experiência de pesquisa qualitativa. In: RAMIRES, J. C. de L.; PESSÔA, V. L. S. Geografia e pesquisa qualitativa nas trilhas da investigação. Uberlândia: Assis Editora, 2009.

CLAVAL, P. A geografia cultural. 2.ed. Florianópolis: Edufsc, 2001.

CARDOZO, I. B. (org.). Etnozoneamento Paiterey Karah: Terra Indígena Sete de Setembro. Porto Velho: Kanindé - Associação de Defesa Etnoambiental, 2011.

CASSIRER, E. Ensaio sobre o homem: introdução a uma filosofia da cultura humana. São Paulo: Martins Fontes, 2005.

MINDLIN, B. Nós Paiter-Os Suruí de Rondônia. Rio de Janeiro: Vozes, 1985. Narradores suruí: vozes da origem. São Paulo: Ática/Iamá, 1996.

TUAN, Yi-Fu. Topofilia: um estudo da percepção, atitudes e valores de meio ambiente. São Paulo: Difel, 1980.

Espaço e lugar: a perspectiva da experiência. São Paulo: Difel, 1983.

ROCHA, G. Multiplicadores do conhecimento. Rede Povo da Floresta. Disponível em: <http://www.redepovosdafloresta.org.br/exibePagina. aspx?pag=292\&pagTipo=n >. Acesso em: 2/2/2012.

KOZEL, S.; SOUZA, L. F. Parintins, que espaço éesse? Representação espacial sob a ática do morador e do visitante. In: KOZEL, S.; SILVA, J. C.; FILIZOLA, R.; GIL FILHO, S. Expedição Amazônica: desvendando espaço e representações dos festejos em comunidades amazônicas. "A festa do boi-bumbá: um ato de fé”. Curitiba: SK, 2009. 
SURUÍ, M. Daqui a 50 anos... In: BAVARESCO, A. Pamine: o renascer da floresta. Reflorestamento da Terra Indígena Paiterey Karah (TI Sete de Setembro) pelo povo Paiter Suruí. Brasília; Cacoal: IEB; Gamebey, 2011.

TEIXEIRA, M. A.; FONSECA, D. R. História regional: Rondônia. Porto Velho: Rondoniana, 1998.

TERRA INDÍGENA Sete de Setembro. Aquaverde. Disponível em: <http:// www.aquaverde.org/por/surui_terra.shtml>. Acesso em: 10/1/2012. 


\author{
SOBRE O LIVRO \\ Formato: $14 \times 21 \mathrm{~cm}$ \\ Mancha: $23,7 \times 42,5$ paicas \\ Tipologia: Horley Old Style 10,5/14 \\ Papel: Offset $75 \mathrm{~g} / \mathrm{m}^{2}$ (miolo) \\ Cartão Supremo $250 \mathrm{~g} / \mathrm{m}^{2}$ (capa) \\ 1ạ edição: 2015 \\ EQUIPE DE REALIZAÇÃO \\ Capa \\ Grão Editorial \\ Edição de texto \\ Dafne Melo (Copidesque) \\ Frederico Ventura (Revisão) \\ Editoração eletrônica \\ Sergio Gzeschnik (Diagramação) \\ Assistência editorial \\ Alberto Bononi
}


Esta obra discute a construção da narrativa histórica dos povos indígenas, refletindo sobre seu vínculo tenso e permanente com a perspectiva do Ocidente. Essa relação levou historiadores, antropólogos e linguistas, a partir de diferentes perspectivas e com diferentes tipos de fontes, a remexer nos discursos contidos nos testemunhos para encontrar o tradicional e o novo, o permanente e o que mudou nas representações e na identidade de nossas populações nativas, enfatizando sua contribuição cultural e social à configuração de nossas sociedades modernas e contemporâneas.

Nos dez ensaios que compõem este livro, os autores recorrem a fontes documentais - iconografias, crônicas, filmes, registros orais - e à historiografia para abordar diferentes temas relativos à representação cultural dos grupos indígenas. 